\title{
Restoration of Forested Ecosystems on the Monongahela National Forest, West Virginia
}

\author{
Melissa A. Thomas-Van Gundy \\ West Virginia University
}

Follow this and additional works at: https://researchrepository.wvu.edu/etd

\section{Recommended Citation}

Thomas-Van Gundy, Melissa A., "Restoration of Forested Ecosystems on the Monongahela National Forest, West Virginia" (2011). Graduate Theses, Dissertations, and Problem Reports. 3416.

https://researchrepository.wvu.edu/etd/3416

This Dissertation is protected by copyright and/or related rights. It has been brought to you by the The Research Repository @ WVU with permission from the rights-holder(s). You are free to use this Dissertation in any way that is permitted by the copyright and related rights legislation that applies to your use. For other uses you must obtain permission from the rights-holder(s) directly, unless additional rights are indicated by a Creative Commons license in the record and/ or on the work itself. This Dissertation has been accepted for inclusion in WVU Graduate Theses, Dissertations, and Problem Reports collection by an authorized administrator of The Research Repository @ WVU.

For more information, please contact researchrepository@mail.wvu.edu. 


\title{
Restoration of Forested Ecosystems on the Monongahela National Forest, West Virginia
}

\section{Melissa A. Thomas-Van Gundy}

\author{
Dissertation submitted to the \\ Davis College of Agriculture, Natural Resources and Design \\ at West Virginia University in partial fulfillment \\ of the requirements for the degree of
}

\author{
Doctor of Philosophy \\ in \\ Forest Resources Science \\ James Rentch, Ph.D., Chair \\ John Edwards, Ph.D. \\ Amy Hessl, Ph.D. \\ Thomas Schuler, Ph.D. \\ Michael Strager, Ph.D. \\ Division of Forestry \\ Morgantown, West Virginia \\ 2011
}

Keywords: Witness trees, European settlement-era forests, historical biogeography, prescribed fire, stand dynamics, LANDIS-II, landscape modeling 


\section{ABSTRACT \\ Restoration of Forested Ecosystems on the Monongahela National Forest, West Virginia}

\section{Melissa A. Thomas-Van Gundy}

The focus of resource management on National Forests is slowly changing to restoration of ecosystems and habitats. In West Virginia, the revised Land and Resource Management Plan for the Monongahela National Forest (MNF) guides resource management on the MNF. The MNF revised Forest Plan restructured management areas and goals toward restoration of red spruce dominated forests and oak and oak-pine forests in two separate management prescriptions that cover approximately $48 \%$ of the MNF. Incorporating ecosystem restoration in forest management may be guided by goals and objectives based on known previous conditions and the range of natural variability of those conditions. The research presented here addresses: 1) the historical distribution and site-species relationships of tree species through the analysis of witness trees from the MNF, 2) stand dynamics of oak-dominated forest types in response to three disturbances, and 3) landscape patterns resulting after simulated restoration actions in highelevation red spruce-dominated forest types.

A database of witness trees taken from land grants or deeds of what was to become the MNF was analyzed for species patterns of occurrence at the time of European settlement. Across the study area, white oak was the most frequent witness tree, followed by sugar maple, American beech, and American chestnut, however none of these were evenly distributed. Red spruce, hemlock, birch, American beech, magnolia, basswood, sugar maple, ash, northern red oak, and black cherry were all associated with higher elevations. Moderate elevations supported maple, pine, white pine, American chestnut, chestnut oak, and scarlet oak. Low elevation sites with high moisture were more likely to support black walnut, white oak, elm, and sycamore.

Three disturbance factors thought to influence the development of seedling and sapling layers of oak dominated hardwood forests were applied alone and in combination on experimental plots in a second-growth forest in eastern West Virginia. In all, eight treatments were applied: Fire, Fence, Gap, Control, Fire+Fence, Fire+Gap, Fence+Gap, and Fire+Gap+Fence. Oak seedlings were not affected by any factor other than time; oak saplings were negatively affected by fire and positively affected by fences. Red and striped maple seedlings and saplings were reduced by fire treatments however sugar maple seedlings and saplings were not. Black birch seedlings increased as fire stimulated germination of the seed bank. Creating gaps alone did not increase the seedling relative abundance or importance value of any of the species assessed here, although gaps when combined with other factors did increase black birch and yellow-poplar seedling relative abundances and sapling importance values.

An existing landscape-sale model (LANDIS-II) was used to create management scenarios that implement possible red spruce restoration actions consistent with the MNF Forest Plan. Three harvest scenarios and one succession only scenario were simulated for 100 years. Harvests for 
all three scenarios were patch cuts of 1 ha with partial removal of selected species and cohorts. Harvest scenarios modeled were: allowing harvest in all areas (S1), restrict harvest to areas of low to moderate probability of Virginia northern flying squirrel habitat only (S2), and allow harvest in all areas but exclude stands with $30 \%$ or greater red spruce 80 years or greater in age (S3); scenario 4 (S4) is succession only. The resulting stands were summarized by age classes and forest types used in the MNF Forest Plan and compared to age class goals. All scenarios resulted in the percentage of 1-19 year age class below the Forest Plan goal; however S3 was the closest at about $2 \%$ in the third decade. At year 30, the three harvest scenarios result in greater area in 20-39 year age class compared to succession only. Scenario 3 meets or slightly exceeds the lower limit of the MNF Forest Plan goal for this age class in years 40 through 70 . For the 4079 year age class, S1 and S3 remained well above S2 and the succession-only scenario in years 30 through 90. At the end of the model period, S1, S2, and S4 meet the MNF Forest Plan goal for this age class. During decades three through nine, S1 and S3 resulted in a consistent $40 \%$ of the area in the 80-119 year age class. All scenarios result in a landscape with much higher percentages of this age class than the MNF Forest Plan goal. For the last two decades of the model, the succession-only scenario results in greater amounts of area in the oldest age class (120 or greater years) as compared to the harvest scenarios. 


\section{TABLE OF CONTENTS}

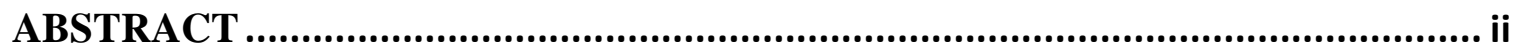

TABLE OF CONTENTS ........................................................................ iv

List of Tables....................................................................................... vii

List of Figures ...........................................................................................

Acknowledgements..................................................................................xvi

CHAPTER 1. ECOLOGICAL RESTORATION ON NATIONAL FORESTS .................... 1

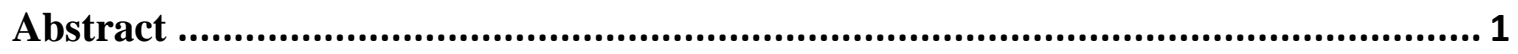

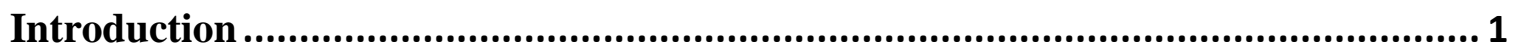

Justification ........................................................................................... 2

Research Objectives ...................................................................................... 8

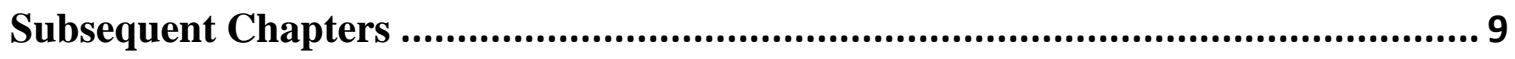

Literature Cited ........................................................................................ 11

\section{CHAPTER 2. EUROPEAN SETTLEMENT-ERA VEGETATION OF THE}

MONONGAHELA NATIONAL FOREST, WEST VIRGINIA........................................... 16

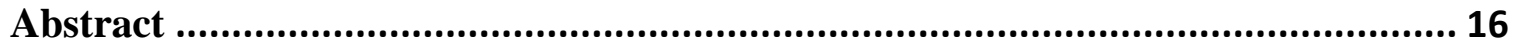

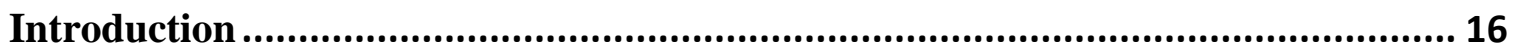

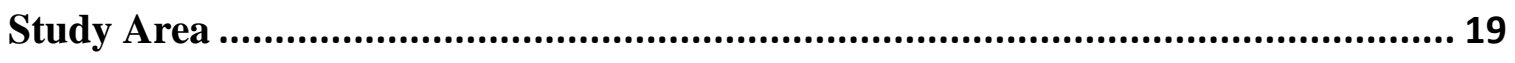

Methods ..................................................................................................... 20

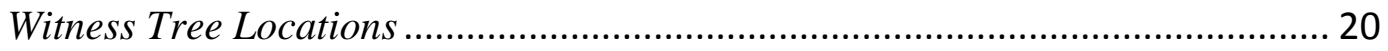

Spatial and Attribute Uncertainty .............................................................. 21

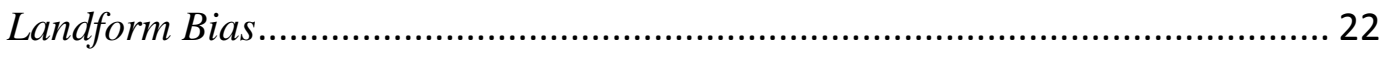

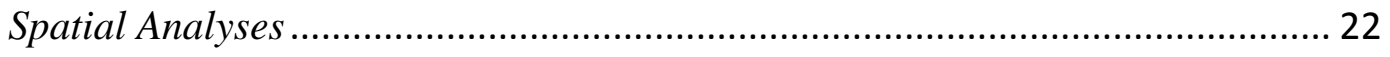

Indicator Species Analysis .......................................................................... 24

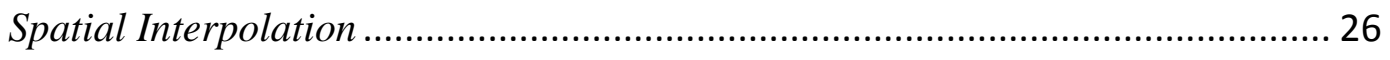

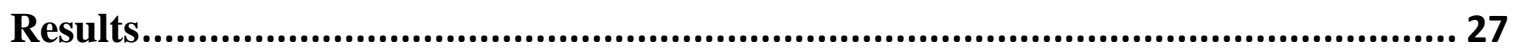




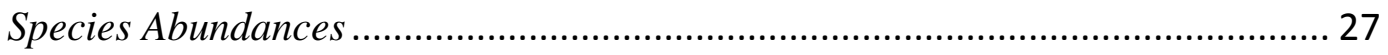

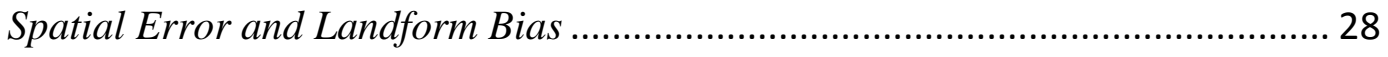

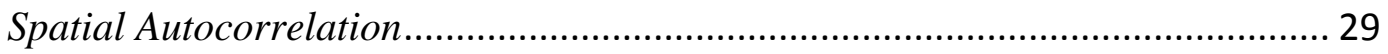

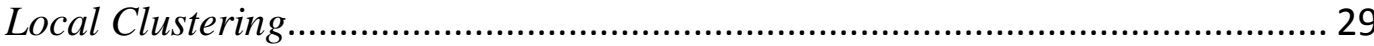

Species-Site Associations …………………………….............................. 31

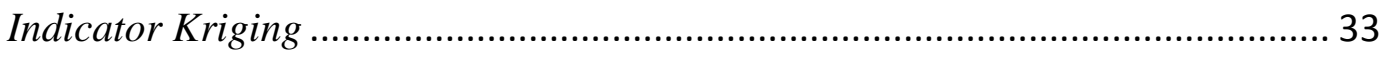

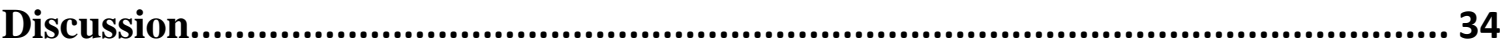

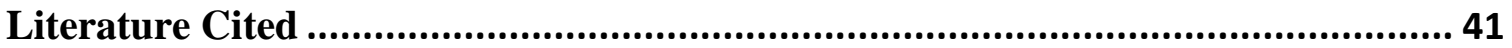

CHAPTER 3. INFLUENCE OF FIRE, BROWSE, AND GAPS ON OAK AND

COMPETITORS IN THE APPALACHIAN MOUNTAINS ............................................... 83

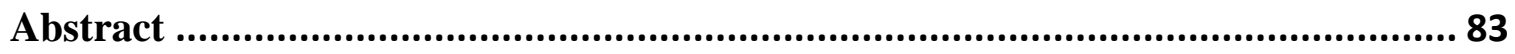

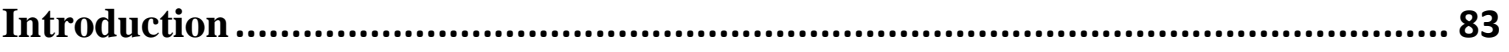

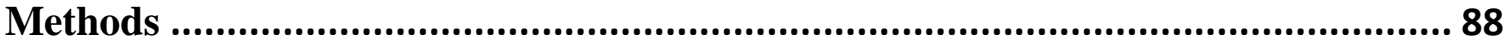

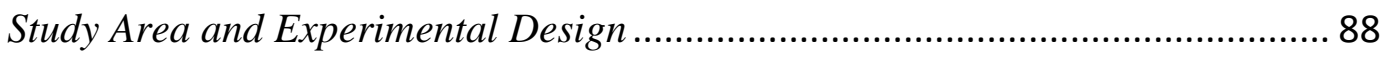

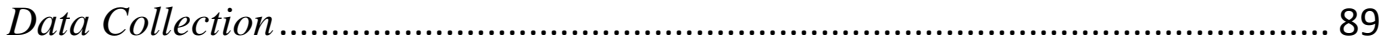

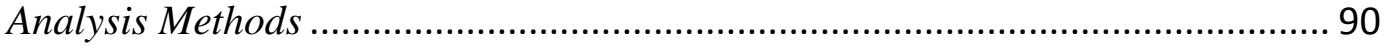

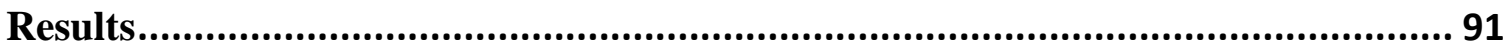

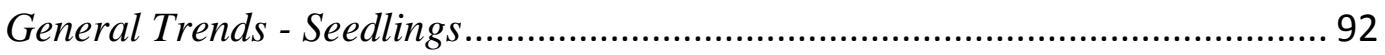

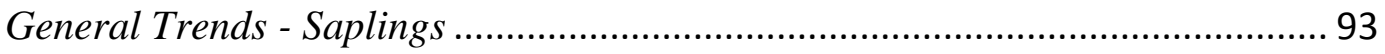

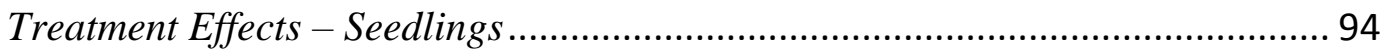

Treatment Effects - Saplings ……………………........................................ 96

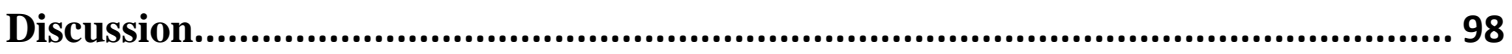

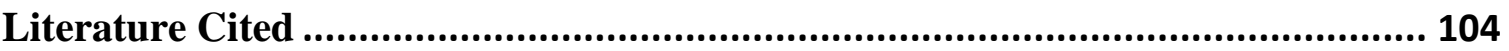

CHAPTER 4. LANDSCAPE-SCALE MODELING OF RED SPRUCE RESTORATION

ALTERNATIVES

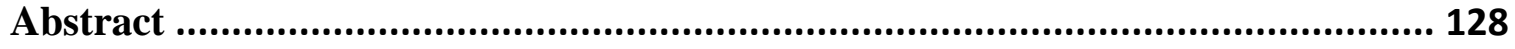

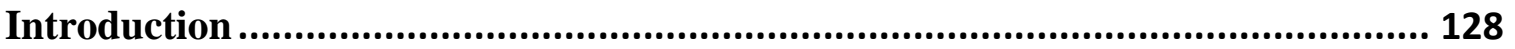

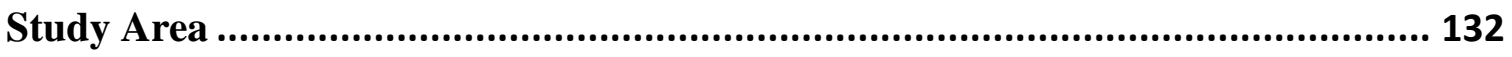

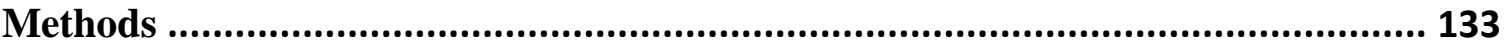




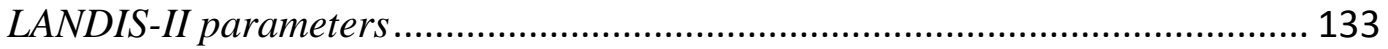

LANDIS-II Prescription and Scenarios ..................................................... 137

Forest Plan Goals and Constraints ................................................................ 139

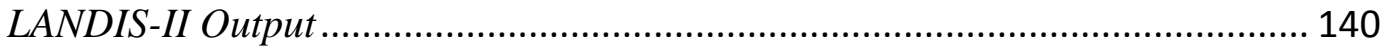

Determination of Sample Size .................................................................... 141

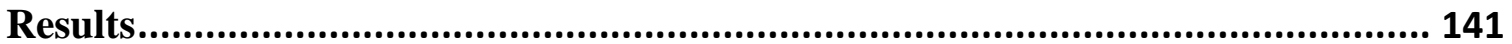

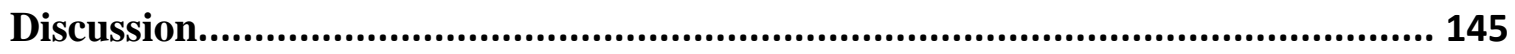

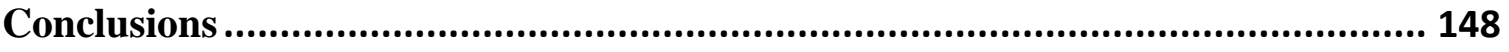

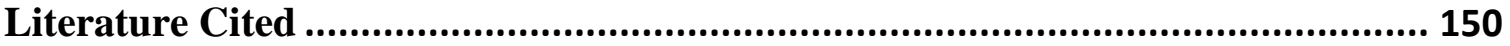




\section{List of Tables}

Table 2.1 - Ecological subsections of the Monongahela National Forest study area (Cleland and others 2007), area within the proclamation boundary and percentage of total for each.

Table 2.2 - Selected subsection climate and potential natural vegetation attributes (Cleland and others 2007). Subsection abbreviations: EAMV = Eastern Allegheny Mountain and Valley, ECF = Eastern Coal Fields, NHAM = Northern High Allegheny Mountain, RV = Ridge and Valley, SHAM = Southern High Allegheny Mountain, WAM = Western Allegheny Mountain, and WAMV = Western Allegheny Mountain and Valley.

Table 2.3 - Species of witness trees cited in deeds dated 1752 to 1899 on the Monongahela National Forest. Common names used in deeds are cross-walked with current scientific names. A question mark after a scientific name represents uncertainty in the assignment of a scientific name to that name used in deeds.

Table 2.4 - Soil series of the Monongahela National Forest used in indicator species analysis. Soils data are from the Monongahela National Forest GIS soils data layer, originally from county soil surveys. For analysis, soil series were grouped by first soil listed in a series or complex and slope and stoniness classes were grouped together.

Table 2.5 - Mean species composition in percent by ecological subsection, for species with 50 or more occurrences across the study area. The results of global Moran's I analysis are included with highlighted totals denoting species with random distribution patterns and the remaining exhibiting significant clustered patterns $(\alpha=0.05)$.

Table 2.6 - Species frequency by subsection and total study area based on presence only. Only those species (or combination of species) with greater than 50 occurrences across the study area were included. Rankings (1-15) given in parentheses.

Table 2.7 - Percent of the study area in selected species based on IK results using $30 \%$ probability of occurrence as threshold.

Table 3.1 - Study area composition pre-treatment (1999) summarized by plot locations. Two study plots are on the Fernow Experimental Forest and two on the Monongahela National Forest.

Table 3.2 - Post-treatment (2007/2008) mean seedling relative abundance by treatment for the Fernow Experimental Forest

Table 3.3 - Post-treatment (2007/2008) mean seedling relative abundance by treatment for Monongahela National Forest plots. 
Table 3.4 - Post-treatment (2007/2008) mean sapling importance values (IV) by treatment for Fernow Experimental Forest plots.

Table 3.5 - Post-treatment (2007/2008) mean sapling importance values (IV) by treatment for Monongahela National Forest plots.

Table 3.6 - Results of GLIMMIX model for mean seedling relative abundances for the Fernow Experimental Forest plots: relative abundances for maple species, black birch, yellow-poplar, and oak species.

Table 3.7 - Results of GLIMMIX model for mean seedling relative abundances for the Monongahela National Forest plots: relative abundances for maple species, black birch, yellow-poplar, and oak species.

Table 3.8 - Results of GLIMMIX model for maple species, black birch, yellow-poplar, and oak species mean sapling importance vales (IV) for the Fernow Experimental Forest plots.

Table 3.9 - Results of GLIMMIX model for maple species, black birch, yellow-poplar, and oak species mean sapling importance values (IV) for the Monongahela National Forest plots

Table 4.1 - Existing age class distribution for red spruce and red spruce-northern hardwood forest types for stands assigned to the 4.1 Management Prescription and the desired future conditions from the Monongahela National Forest, Forest Plan. Distributions are expressed as a percentage of area in that age class relative to the total area in these forest types. 155

Table 4.2. - Initial community information based on Monongahela National Forest stand data used to initialize the model. Stands with no information make up 5.5 percent of the study area (39.5 percent of the model area).

Table 4.3. - Life history characteristics by species used as input for all LANDIS-II scenarios.

Table 4.4 - Probability of seedling establishment parameters from LINKAGES (Pastor and Post 1985) used in all LANDIS-II scenarios.

Table 4.5 - Soil and climate data by ecoregion used to calculate seedling establishment probabilities used in all LANDIS-II scenarios. Soil data were calculated from MNF soil pits, climate data are from the National Climatic Data Center (NOAA 2009). 158

Table 4.6 - Probabilities of seedling establishment used in all LANDIS-II scenarios. These probabilities were determined through a LANDIS-II calculator based on the LINKAGES model (Pastor and Post 1985) with inputs from Tables 4.4 and 4.5.

Table 4.7 - Relevant biomass parameters used in all LANDIS-II scenarios. 159 
Table 4.8 - Forest types by percent of total study area (MP4.1 stands only) by scenario and model year. 


\section{List of Figures}

Figure 2.1 - Study area location and physiographic subsections. Thicker boundary line is between

Northern Ridge and Valley and Allegheny Mountains Sections.

Figure 2.2 - Locations of corners from all deeds in relation to the proclamation boundary of the Monongahela National Forest and this boundary buffered by five kilometers.

Figure 2.3 - Number of corners per decade based on deed date grouped by decade. Twelve deeds with unknown dates were not included.

Figure 2.4 - Results of local cluster analysis for beech, sugar maple, white oak, and red spruce witness trees. Analysis results in the identification of hot spots (HH), cold spots (LL), and spatial outliers (HL or LH). Points with no cluster designation are not displayed. Scale for each map is 1:740,000. .58

Figure 2.5 - Results of local cluster analysis for white pine, pine, magnolia, and hemlock witness trees. Analysis results in the identification of hot spots (HH), cold spots (LL), and spatial outliers (HL or LH). Points with no cluster designation are not displayed. Scale for each map is 1:740,000.

Figure 2.6 - Results of local cluster analysis for ash, yellow-poplar, elm, and sycamore witness trees. Analysis results in the identification of hot spots (HH), cold spots (LL), and spatial outliers (HL or LH). Points with no cluster designation are not displayed. Scale for each map is 1:740,000.

Figure 2.7 - Results of local cluster analysis for chestnut oak, scarlet oak, red oak, and black oak witness trees. Analysis results in the identification of hot spots (HH), cold spots (LL), and spatial outliers (HL or LH). Points with no cluster designation are not displayed. Scale for each map is 1:740,000.

Figure 2.8 - Results of local cluster analysis for hickory, American chestnut, black locust, and blackgum witness trees. Analysis results in the identification of hot spots (HH), cold spots (LL), and spatial outliers (HL or LH). Points with no cluster designation are not displayed. Scale for each map is 1:740,000, .....62

Figure 2.9 - Results of local cluster analysis for black cherry, spruce-pine, birch, and maple witness trees. Analysis results in the identification of hot spots (HH), cold spots (LL), and spatial outliers (HL or LH). Points with no cluster designation are not displayed. Scale for each map is 1:740,000.

Figure 2.10 - Results of local cluster analysis for basswood, black walnut, and butternut witness trees. Analysis results in the identification of hot spots (HH), cold spots (LL), and spatial outliers (HL or LH). Points with no cluster designation are not displayed. Scale for each map is 1:740,000. 64

Figure 2.11 - Significant associations $(\alpha=0.05 ; \mathrm{n} \geq 10)$ between tree species and environmental variables (landform, aspect, TRI, moisture index, elevation, and soil series) for the study area (all subsections). 
Blank (white) cells indicate no significant association for that species-site variable combination. The species are grouped first by their association with elevation class

Figure 2.12 - Significant associations $(\alpha=0.05 ; \mathrm{n} \geq 10)$ between tree species and environmental variables (landform, aspect, TRI, moisture index, elevation, and soil series) for the EAMV subsection. Blank (white) cells indicate no significant association for that species-site variable combination. The species are grouped first by their association with elevation class. 66

Figure 2.13 - Significant associations $(\alpha=0.05 ; \mathrm{n} \geq 10)$ between tree species and environmental variables (landform, aspect, TRI, moisture index, elevation, and soil series) for the ECF subsection. Blank (white) cells indicate no significant association for that species-site variable combination. The species are grouped first by their association with elevation class.

Figure 2.14 - Significant associations $(\alpha=0.05 ; n \geq 10)$ between tree species and environmental variables (landform, aspect, TRI, moisture index, elevation, and soil series) for the NHAM subsection. Blank (white) cells indicate no significant association for that species-site variable combination. The species are grouped first by their association with elevation class..... 68

Figure 2.15 - Significant associations $(\alpha=0.05 ; n \geq 10)$ between tree species and environmental variables (landform, aspect, TRI, moisture index, elevation, and soil series) for the RV subsection. Blank (white) cells indicate no significant association for that species-site variable combination. The species are grouped first by their association with elevation class.

Figure 2.16 - Significant associations $(\alpha=0.05 ; \mathrm{n} \geq 10)$ between tree species and environmental variables (landform, aspect, TRI, moisture index, elevation, and soil series) for the WAM subsection. Blank (white) cells indicate no significant association for that species-site variable combination. The species are grouped first by their association with elevation class. 70

Figure 2.17 - Significant associations $(\alpha=0.05 ; \mathrm{n} \geq 10)$ between tree species and environmental variables (landform, aspect, TRI, moisture index, elevation, and soil series) for the SHAM subsection. Blank (white) cells indicate no significant association for that species-site variable combination. The species are grouped first by their association with elevation class. 71

Figure 2.18 - Significant associations $(\alpha=0.05 ; \mathrm{n} \geq 10)$ between tree species and environmental variables (landform, aspect, TRI, moisture index, elevation, and soil series) for the WAMV subsection. Blank (white) cells indicate no significant association for that species-site variable combination. The species are grouped first by their association with elevation class.

Figure 2.19 - Indicator kriging results for sugar maple witness trees. Interpolations were made on presence/absence of the selected species. Results are given in terms of probability of occurrence. 73 
Figure 2.20 - Indicator kriging results for sugar maple or basswood witness trees. Interpolations were made on presence/absence of the selected species. Results are given in terms of probability of occurrence.

Figure 2.21 - Indicator kriging results for sugar maple or American beech witness trees. Interpolations were made on presence/absence of the selected species. Results are given in terms of probability of occurrence.

Figure 2.22 - Indicator kriging results for red spruce witness trees. Interpolations were made on presence/absence of the selected species. Results are given in terms of probability of occurrence. 76

Figure 2.23 - Indicator kriging results for red spruce or birch witness trees. Interpolations were made on presence/absence of the selected species. Results are given in terms of probability of occurrence.

Figure 2.24 - Indicator kriging results for white oak witness trees. Interpolations were made on presence/absence of the selected species. Results are given in terms of probability of occurrence.

Figure 2.25 - Indicator kriging results for white oak or white pine witness trees. Interpolations were made on presence/absence of the selected species. Results are given in terms of probability of occurrence.

Figure 2.26 - Indicator kriging results for American chestnut witness trees. Interpolations were made on presence/absence of the selected species. Results are given in terms of probability of occurrence. .80

Figure 2.27 - Indicator kriging results for American chestnut or chestnut oak witness trees. Interpolations were made on presence/absence of the selected species. Results are given in terms of probability of occurrence.

Figure 2.28 - Indicator kriging results for red, scarlet, black, or chestnut oak witness trees. Interpolations were made on presence/absence of the selected species. Results are given in terms of probability of occurrence.

Figure 3.1 - General study area and locations of main plots.

Figure 3.2-Generalized treatment layout for one main plot. Fire was randomly assigned to one half of the plot. Gap and fence were randomly assigned to sampling plots.

Figure 3.3 - Significant $(\alpha=0.05)$ two-way interactions for seedlings on Fernow Experimental Forest plots. All comparisons are made for the post-treatment time period only. Means $( \pm \mathrm{SE})$ are summarized across the third treatment factor. 
Figure 3.4 - Significant $(\alpha=0.05)$ two-way interactions for seedlings on Monongahela National Forest plots. All comparisons are made for the post-treatment time period only. Means $( \pm \mathrm{SE})$ are summarized across the third treatment factor.

Figure 3.5 - Means ( \pm SE) of selected seedling relative abundances across the eight treatments on the Fernow Experimental Forest study plots post-treatment. Means with the same letter are not significantly different $(\alpha=0.05)$

Figure 3.6 - Means ( \pm SE) of selected seedling relative abundances across the eight treatments on the Monongahela National Forest study plots post-treatment. Means with the same letter are not significantly different $(\alpha=0.05)$.

Figure 3.7 - Significant $(\alpha=0.05)$ two-way interactions for saplings on the Fernow Experimental Forest plots. All comparisons are made for the post-treatment time period only. Means $( \pm S E)$ are summarized across the third treatment factor. 124

Figure 3.8 - Significant $(\alpha=0.05)$ two-way interactions for saplings on the Monongahela National Forest plots. All comparisons are made for the post-treatment time period only. Means $( \pm S E)$ are summarized across the third treatment factor. 125

Figure 3.9 - Means ( \pm SE) of selected sapling IV across the eight treatments on the Fernow Experimental Forest study plots post-treatment. Means with the same letter are not significantly different $(\alpha=0.05)$.

Figure 3.10 - Means $( \pm$ SE) of selected sapling IV across the eight treatments on the Monongahela National Forest plots post-treatment. Means with the same letter are not significantly different $(\alpha=0.05)$.

Figure 4.1 - Location of study area and model area. Stands assigned to management prescription (MP) 4.1 in the Monongahela National Forest Forest Plan were buffered by $5 \mathrm{~km}$ to create the model area; however results are only reported for the MP4.1 (study) area.

Figure 4.2 - Mean percentage $( \pm \mathrm{SE})$ of red spruce and red spruce-northern hardwood forest types for the 1-19 year age class as a result of implementing the four LANDIS-II scenarios; National Forest land in MP4.1 only. The four model scenarios are: 1) harvest in both management areas (S1), 2) harvest in management area one only (low-to moderate probability of VNFS occupation, S2), 3) harvest in both management areas with the exclusion of stands with $30 \%$ or greater red spruce of 80 years or older (S3), and 4) succession only (S4). 162

Figure 4.3 - Mean percentage $( \pm \mathrm{SE})$ of red spruce and red spruce-northern hardwood forest types for the 20-39 year age class as a result of implementing the four LANDIS-II scenarios; National Forest land in MP4.1 only. The four model scenarios are: 1) harvest in both management areas (S1),2) harvest in management area one only (low-to moderate probability of VNFS occupation, S2), 3) harvest in both 
management areas with the exclusion of stands with $30 \%$ or greater red spruce of 80 years or older (S3), and 4) succession only (S4). 163

Figure 4.4 - Mean percentage $( \pm \mathrm{SE})$ of red spruce and red spruce-northern hardwood forest types for the 40-79 year age class as a result of implementing the four LANDIS-II scenarios; National Forest land in MP4.1 only. The four model scenarios are: 1) harvest in both management areas (S1), 2) harvest in management area one only (low-to moderate probability of VNFS occupation, S2), 3) harvest in both management areas with the exclusion of stands with $30 \%$ or greater red spruce of 80 years or older (S3), and 4) succession only (S4).

Figure 4.5 - Mean percentage $( \pm \mathrm{SE})$ of red spruce and red spruce-northern hardwood forest types for the 80-119 year age class as a result of implementing the four LANDIS-II scenarios; National Forest land in MP4.1 only. The four model scenarios are: 1) harvest in both management areas (S1), 2) harvest in management area one only (low-to moderate probability of VNFS occupation, S2), 3) harvest in both management areas with the exclusion of stands with $30 \%$ or greater red spruce of 80 years or older (S3), and 4) succession only (S4). 165

Figure 4.6 - Mean percentage $( \pm \mathrm{SE})$ of red spruce and red spruce-northern hardwood forest types for the $120+$ year age class as a result of implementing the four LANDIS-II scenarios; National Forest land in MP4.1 only. The four model scenarios are: 1) harvest in both management areas (S1), 2) harvest in management area one only (low-to moderate probability of VNFS occupation, S2), 3) harvest in both management areas with the exclusion of stands with $30 \%$ or greater red spruce of 80 years or older (S3), and 4) succession only (S4). 166

Figure 4.7 - Age classes over time for red spruce and red spruce-northern hardwood forest types combined as a result of implementing S1 in LANDIS-II. Scale for all maps is 1:24,000.

Figure 4.8 - Age classes over time for red spruce and red spruce-northern hardwood forest types combined as a result of implementing S2 in LANDIS-II. Scale for all maps is 1:24,000. 168

Figure 4.9 - Age classes over time for red spruce and red spruce-northern hardwood forest types combined as a result of implementing S3 in LANDIS-II. Scale for all maps is 1:24,000.

Figure 4.10 - Age classes over time for red spruce and red spruce-northern hardwood forest types combined as a result of implementing S4 in LANDIS-II. Scale for all maps is 1:24,000. 170

Figure 4.11 - Area harvested $( \pm$ SE) by model decade; National Forest land in MP4.1 only. Average values are for three model runs for each of the three scenarios that include harvest: 1) harvest in both management areas (S1), 2) harvest in management area one only (low-to moderate probability of VNFS occupation, S2), 3) harvest in both management areas with the exclusion of with $30 \%$ or greater red spruce of 80 years or older (S3). 
Figure 4.12 - Species removals by decade as a percent of total cohorts removed for S1 - harvests in both management areas.

Figure 4.13 - Species removals by decade as a percent of total cohorts removed for S2 - harvests in management area 1 only.

Figure 4.14 - Species removals by decade as a percent of total cohorts removed for S3 - harvests in both management areas, excluding with $30 \%$ or more red spruce of 80 years or older.

Figure 4.15 - Ages of harvested stands by decade as percent of total stands harvested for S1 - harvests in both management areas.

Figure 4.16 - Ages of harvested stands by decade as percent of total stands harvested for S2 - harvests in management area 1 only.

Figure 4.17 - Ages of harvested stands by decade as percent of total stands harvested for S3 - harvests in both management areas, excluding stands with $30 \%$ or more red spruce of 80 years or older.

Figure 4.18 - Percentage of the study area in variety classes by LANDIS-II scenario. 


\section{Acknowledgements}

Many people have helped me get to this point. I'd like to thank my committee chair, Jim Rentch, for taking me on toward the end of this process and for Eric Heitzman for getting me started. Also, thanks to the rest of my committee for sticking with me and providing guidance. Many others have helped make certain parts of this work possible including Dave Cleland for initial funding of the witness tree database and Mike Metz and other WVU students who helped create the digital database. Walt Carson and Rachel Collins initiated the Fire-Fence-Gap study and I thank them for working with the Fernow Experimental Forest on this study. John Stanovick helped with SAS; Frederica Wood created better figures and was always helpful as a check on my logic. Brian Sturtevant and Brian Miranda were a huge help on the LANDIS-II modeling, on everything from the nuts and bolts of the software to helping me focus the questions to ask of the model. Lastly, thanks to my husband Doug for putting up with the loss of my sense of humor at times and for his continued support of my career. 
Chapter 1. Ecological Restoration on National Forests

\begin{abstract}
Ecosystem restoration is introduced and discussed as it relates to management of the resources of the Monongahela National Forest (MNF) in east-central West Virginia. Some information needs for restoring ecosystems are identified and methods to fill these knowledge gaps for the MNF are proposed. Specifically, research will address: 1) the historical distribution and site-species relationships of tree species through the analysis of witness trees, 2) stand dynamics of oakdominated forests in response to three disturbances - deer browse, canopy gaps, and understory fire and 3) landscape patterns resulting after simulated restoration actions in high-elevation red spruce-dominated forest types.
\end{abstract}

\title{
Introduction
}

Ecological stressors such as severe wildfires, insect and disease outbreaks, changes in land use, exploitative land use, and non-native invasive species all present challenges to carrying out the USDA Forest Service's mission "to sustain the health, diversity, and productivity of the nation's forests and grasslands to meet the needs of present and future generations" (USDA 2007). These challenges also present opportunities to restore ecosystem health, diversity, and productivity to forests and grasslands.

In 2006 the USDA Forest Service addressed ecological restoration as it pertains to management of national forests and grasslands, resulting in a framework for a national strategy (Day and others 2006). In this framework is a definition of ecosystem restoration to be used by the national forests. In an effort to build on existing research and theory of the relatively new science of ecological restoration, the Forest Service adopted the definition used by the Society for Ecological Restoration; restoration is "the process of assisting the recovery of an ecosystem that has been degraded, damaged, or destroyed" (SER 2008). Restoration involves reestablishing species composition, structure, function, and processes to an ecosystem based on what is known or can be confidently inferred about the past, but also considering future threats.

Incorporating ecosystem restoration in forest management should be guided in part by previous conditions and the range of natural variability of those conditions. However, restoration should not (and realistically cannot) attempt to simply re-create conditions at some static point in time. Defined forest communities are human constructs that place compositional and temporal boundaries across lines that may not be ecologically distinct (O’Neill 2001). 
However, these constructs are needed to describe current conditions, identify rare or important habitats, and envision future forests.

The ultimate goal of ecosystem restoration is recovery of ecosystem processes and functions within the range of historic variability. For example, the red spruce (Picea rubens)dominated forests of West Virginia were severely degraded in composition and function after the exploitative logging of over a century ago. Harvesting and subsequent fires removed seed sources and changed soil conditions allowing northern hardwoods to dominate former spruce forests. Managing stands and landscapes to give a competitive advantage to existing red spruce or to return red spruce directly through planting are examples of restoring the red spruce ecosystem.

\section{Justification}

In West Virginia, the revised Land and Resource Management Plan (Forest Plan) for the Monongahela National Forest (MNF) guides resource management on the MNF (USDA 2006). Management prescription areas are the planning units where broad goals and objectives are applied for a given emphasis. The Forest Plan is a guiding document outlining desired future conditions, actions allowed to meet those conditions, constraints on actions to protect resource values, and standards and guidelines for implementation of actions. All of the items above may vary by management prescription. The Forest Plan is supported by an environmental impact statement disclosing the possible effects of the actions allowed by the Forest Plan.

The MNF revised Forest Plan restructured management areas and goals toward restoration of red spruce-dominated forests and oak (Quercus spp.) and oak-pine (Pinus spp.) forests in two separate management prescriptions that cover approximately $48 \%$ of the MNF. These management areas include national forest land ecologically suited for these goals, although the boundaries were defined at the landscape level so the larger management area may include small areas not truly suited to the given restoration targets.

The MNF Forest Plan identified the red spruce and red spruce-northern hardwood forests for restoration based on the reduction in historic extent of this forest type, the regeneration potential exhibited in many areas by natural regeneration of red spruce, and the need to expand and connect rare species habitat. These cool, moist, high elevation red spruce-dominated forests support many rare communities and species. Included in the forest matrix are sphagnum bogs 
and other wetland types uncommon in a region dominated by mountains. Rare species supported by spruce-dominated forests in West Virginia include, the federally endangered Virginia northern flying squirrel (VNFS; Glaucomys sabrinus fuscus), the federally threatened Cheat Mountain salamander (Plethodon nettingi), snowshoe hare (Lepus americanus), balsam fir (Abies balsamea), and Canadian bunchberry (Cornus canadensis) which is listed as state-rare for West Virginia. This rare forest type also adds to regional diversity by providing habitat for both northern species such as hobble bush (Viburnum lantanoides) and mountain ash (Sorbus americana), and southern species such as Southern mountain cranberry (Vaccinium erythrocarpon) and minniebush (Menziesia pilosa), as well as liverwort, moss, and bryophyte communities.

Since commercial harvest of red spruce does not occur on the MNF and red spruce is regenerating naturally in West Virginia and elsewhere (Pauley 1989; Fortney 1993, Mayfield and Hicks 2010, Nowacki and others 2010), this high-elevation forest does appear to be slowly recovering from the impacts of 1900s exploitative harvesting. The goal of active restoration proposed in the MNF Forest Plan is to reduce the time for red spruce to reach the overstory and increase the amount of area in red spruce and red spruce-northern hardwoods forest types. Red spruce is very tolerant of shade and can respond to release after decades of suppression (Korstian 1937; Hart 1959, Burns and Honkala 1990) so existing regeneration could be released from the hardwood overstory. The current forest is generally even-aged, having been created by the largescale, nearly complete removal of trees during the exploitative timber harvest period before federal ownership.

Red spruce forests in West Virginia occur at the highest elevations in mountainous areas where precipitation inputs are high (including extended cloud cover) and yearly average temperatures are low. In actively managing to restore red spruce forests on the MNF, the goal is not to move the ecological clock backwards; instead it is an attempt to give red spruce an advantage in the current forests. Both active and passive management were envisioned for the restoration of red spruce dominated forest of the MNF. Active management includes patch cutting, thinning, and planting.

Active management of red spruce-northern hardwood forests could accelerate the creation of uneven-aged structure and composition in targeted stands and increase red spruce abundance in the overstory (Schuler and others 2002; Rentch and others 2007). At the stand 
level, simulations have found that crown thinning delayed spruce movement to the canopy, while thinning from below increased the importance of red spruce (Schuler and others 2002). These findings were reinforced by 100-year growth simulations of red spruce release and no-release scenarios on second-growth northern hardwood stands with understory red spruce (Rentch and others 2007). The authors found that thinning from above to 50\% of the original basal area could double red spruce basal area in 20 to 40 years.

Passive restoration (allowing succession to occur without interference) of these forests is hampered by the slow maturity of red spruce to seed bearing age, loss of seed source, and limited dispersal distance of seed (Pielke 1981). Spruce regeneration is also hampered by abundant reproduction of shade intolerant hardwoods. Given the extreme shade tolerance of red spruce, Westveld (1953) recommended all-aged management as the preferred silvicultural system. Hornbeck and Kochenderfer (1998) recommended removal of the overstory with possible retention of any canopy spruce or valuable hardwoods such as black cherry (Prunus serotina) to release a red spruce understory from a largely low-grade hardwood overstory. Areas of lowgrade hardwoods with red spruce regeneration may represent the best opportunity to easily increase the extent of spruce dominated forests in West Virginia.

Oak and oak-pine forests were targeted for active restoration based on the difficulty in regenerating oaks on many sites where they have been historically dominant, and the growing body of research showing the role of fire in the regeneration of oak species in these forest types. There are many lines of evidence to suggest fire has played a role in the development of eastern hardwood forests and that this disturbance regime has been greatly altered from previous centuries.

Dendrochronological studies in oak-dominated forests have found a range of fire return intervals. On ridges in western Maryland, the fire return interval was found to be 7.6 years based on fire scars from white $(Q . a l b a)$ and chestnut oaks (Q. prinus) and oaks were found to have recruited to the overstory consistently from the early 1600s to the early 1900s (Shumway and others 2001). Fire suppression in 1930 coincided with increases in maple and birch in the stand (Shumway and others 2001). Northern red oak (Q. rubra) stumps revealed a 156-yr history of a settlement-era forest in Pendleton County, West Virginia. The median fire interval for this site was 14.7 years when calculated based on one or more trees scared during a single year and 17.1 years when calculated with at least two trees scarred in a single year (Schuler and McClain 
2003). In 1937, after an unusually long fire-free interval for the site, oak recruitment ceased (Schuler and McClain 2003). Within this same area, Hessl and others (in review) found fire return intervals of just over seven years for two pine species. A study to understand and document past fire regimes in small patches of xerophytic Table Mountain pine ( $P$. pungens) dominated stands on the ridges of the central Appalachian Mountains has found that fires occurred at 2-3 year intervals between 1758 and 1934 (DeWeese 2007). These patches are found within a hardwood matrix dominated by oak species and fires recorded in the pine stands likely influenced the surrounding forest matrix. Fire return intervals were undoubtedly effected by stochastic events, but the presence of repeated fire is important to understanding past disturbance regimes.

Another line of evidence for fire and its effects on eastern forests is found in the sediments of lakes, ponds, and in soil charcoal. Changes in species composition can show indirect evidence of changing disturbance regimes and sediment charcoal gives direct evidence of local and regional fires. Coupling this ecological information with the archaeological record can give a more complete picture of the disturbances shaping the forests. For the past 4,000 years, oaks and American chestnut (Castanea dentata) have dominated the forest surrounding the Horse Cove bog in North Carolina and local fires increased during the Woodland period (Delcourt and Delcourt 1997). Direct evidence for pre-Columbian Native American use of fire was also found in southeastern Kentucky and east Tennessee (Delcourt and Delcourt 1998). Pollen and charcoal in pond sediments yielded evidence for direct relationship between prehistoric Native American use of fire and increases in the importance of oak-American chestnut forest between 3,000 to 1,000 years ago (Delcourt and Delcourt 1998). This corresponds with the change in lifestyle to more sedentary cultivation of native plants in the Woodland cultural period (Delcourt and Delcourt 1998).

Using soil charcoal to document fire histories is a fairly recent technique and may be limited in its use due to costs of dating charcoal. However, in areas without long-term dendrochronological data and few lakes or ponds, soil charcoal can give a coarse-scale idea of fire history. Soil charcoal was collected in a North Carolina forest across an environmental gradient from xeric oak-pine ridge forests to downslope mesic hardwood forests and dated through radiocarbon methods (Fesenmyer and Christensen 2010). The analysis showed that fires were not confined to the dry ridge tops and suggests that fires occurred regularly across the study 
area, increasing in frequency about 1,000 years ago (Fesenmyer and Christensen 2010). This increase coincides with the presence of Woodland-era Native Americans in the area (Fesenmyer and Christensen 2010).

The written accounts of early explorers and settlers can be useful for generalizations about the condition of the land at the time of European settlement and the uses of the land by Native Americans. Early accounts list sightings of meadows, fields, and recently closed forests and use of fire by Native Americans (Maxwell 1910). A review of original accounts documented fire use by Native Americans in the southern Appalachians for forest management, driving game, and preparing land for agriculture (DeVivo 1991). The potential for Native American ignition, based on estimates of Native American populations and the number of fires set by each individual per year was compared to the potential for ignition by lightning (Kay 2007). Even using the lowest published estimates of the Native American population of Canada and the United States (before European influences) and assuming one escaped campfire per year per person, the potential for human caused ignitions were 2.7 to 350 times greater than current ignition rates due to lightning (Kay 2007). However, studies at a more local scale show the importance of lightning in current forests with direct evidence of lightning strikes and individual tree ignitions (Ruffner and Abrams 1998). Lightning and/or large fires were considered important for maintaining frequent fires in pine-oak stands before European settlement but in the absence of a local Native American population (Aldrich and others 2010).

While the exact historic frequency of fire may not be known for a landscape or region, land managers have begun using fire as a silvicultural tool in an effort to enhance oak regeneration. Oaks are not well adapted to low light conditions, although seed will germinate in shade, and late successional oak forests are limited to the most xeric sites (Abrams 1992). However, oaks do posses many ecophysiological factors that indicate adaptation to fire, such as thick bark on mature trees, ability to sprout, sprouting from the root collar, and rot resistance (Abrams 1992). Also, the results of prescribed fire studies should show whether fire benefits oaks and discourages its competitors.

Many studies show advantages are conferred on oak species with fire through reduction of interfering vegetation and/or increased root:shoot ratios of oaks (Arthur and others 1998; Clatterbuck 1998; Barnes and Van Lear 1998; Elliott and others 1999; Signell and others 2005; Blankenship and Arthur 2006; Iverson and others 2008). Often, more than one fire and reduction 
of overstory density shows greatest benefit to oaks (Loftis 1990; Keyser and others 1996; Brose and Van Lear 1998; Brose and others 1999a; Brose and others 1999b; Brose and Van Lear 1999).

Others have noted little to no positive impact of fire on oak species (Collins and Carson 2003), finding that vigorous oak sprouts were not produced by top-killed oak saplings and no seedling-sprouts were found. Many studies point out the need for more than a single prescribed fire to reverse the effects of decades of fire suppression and absence of ignitions (Wendel and Smith 1986; Jackson and Buckley 2004; Hutchinson and others 2005; Albrecht and McCarthy 2006). Fire does top-kill oak seedlings and sprouts, so reduction in their numbers is expected immediately after a fire. Repeated burning and resprouting of oaks and their competitors is expected to create conditions where competitors such as red maple and yellow-poplar deplete their energy reserves faster than oaks due to physiological differences (Lorimer 1985).

Many other changes have occurred in the eastern forests besides the suppression of fire that may also contribute to the oak regeneration problem. Oaks may have gained their overstory dominance because of rapid land use changes, including European use of fire, and forest clearing and grazing between 1880 and 1930 (McEwan and others 2007). The loss of the American chestnut was found to have increased the importance of chestnut oak, northern red oak, and red maple (Acer rubrum) in oak-chestnut forests (Woods and Shanks 1959) and the loss of this mast producing species also put greater pressure on oak regeneration through increased acorn predation. The loss of the passenger pigeon (Ectopistes migratorius) may have also influenced oak regeneration by removing this disturbance factor that might have favored oaks (Ellsworth and McComb 2003). Conversely, the reductions in deer (Odocoileus virginianus) and turkey (Meleagris gallopavo) flocks after the turn of the $20^{\text {th }}$ century logging may have given an advantage to regenerating oaks (McEwan and others 2010). Declines in oak regeneration may be linked to climate change from frequent and intense droughts during the 1500-1900s, to increased moisture availability during the past 100 years (McEwan and others 2010).

While fire is not the only variable affecting oak regeneration or the only variable to have changed during the Holocene, it is an ecological process that can be reintroduced to the oakdominated forests of the MNF. Evidence from modern prescribed fires coupled with the physiological characteristics of oaks give supporting evidence that oaks are adapted to and benefit from conditions created with fire. As for other ecosystem drivers important in oak 
forests, prescribed fire on the MNF is often used in conjunction with timber harvest to increase light to the forest floor. This can be seen as recreating, on a smaller scale, the site conditions that allowed for oak regeneration after exploitative logging of about 100 years ago. Control of deer browse does occur on some harvested sites on the MNF, with or without prescribed fire, but has generally been limited due to cost and difficulty in fencing large areas on uneven terrain.

Drought cycles are, of course, out of the control of forest managers; however prescribed fire can be used to reduce mesic conditions at the stand or landscape level (Nowacki and Abrams 2008). Fire is likely not the only driver affecting oak regeneration in eastern forests, however it is one that can be re-introduced and affects many components of the system including forest floor, understory, midstory, and possibly overstory depending on fire intensity.

For these reasons, returning fire to certain ecosystems through the use of prescribed fire was included in the MNF Forest Plan and represents a significant change in management for the MNF. Using prescribed fire is also an attempt to restore a process, subsequent structures such as standing dead trees, and oak regeneration to oak-dominated forests on the MNF. During and after the extractive logging boom of the late 1800s to about 1910, the forests of West Virginia were vulnerable to fire because of vast areas of timber residue and the use of steam powered trains that provided ignition sources. Fire control and suppression efforts initiated in the 1930s were successful at removing this disturbance regime from West Virginia forests. Not all forest types on the MNF are suited to fire as a disturbance. The areas of the MNF where restoring red spruce dominance is the objective and those oak-dominated forests where fire is to be returned are largely mutually exclusive by design of the management prescription areas in the Forest Plan.

\section{Research Objectives}

Proposing to restore an ecological system involves answering questions such as; what are the restoration goals and how do we measure success? Restoration should include reestablishing patterns, processes, and species in the context of a given space and time frame. To accomplish ecological restoration goals outlined in the MNF Forest Plan, land managers need information about historical conditions. Information on historical forest conditions is sparse for much of the eastern United States due to early settlement by Europeans and intensive timber harvest early in the $20^{\text {th }}$ century. Descriptions and quantitative assessments of early forests and grasslands are useful in restoration ecology and can come from many sources such as land survey records, 
traveler's accounts, and photographs (Whitney 1994). In the absence of large old-growth forests, these historical references are often the best source of information on forest characteristics at European settlement, can provide clues to Native American influences on the landscape, and can inform restoration actions. For the MNF, a set of maps and land grants compiled in the 1930s was converted to a digital database of corner or witness trees from the first record of land exchange in the area. These witness tree data were used to describe species diversity and species-environment relations at the time of European settlement.

As with any management, managers need to know what actions accomplish the goals of restoring patterns and processes and need to be able to predict the results of management actions. To help predict the results of management in oak-dominated forests on the MNF, I assessed the outcome of a stand-level prescribed fire study, referred to here as the Fire-Fence-Gap study (Collins and Carson 2003). In this study, the responses of oak species and their competitors to disturbances alone and in combination, were analyzed adding to the knowledge of prescribed fire in oak forests and the utility of prescribed fire as a restoration tool. This study also included reduction in browse through fencing and increased sunlight to the forest floor by snag creation.

To explore the efficacy of active management for restoration of red spruce-dominated

forests, I used a landscape-scale model (LANDIS -II) to track the development of red spruce and red spruce-northern hardwood forests as management permitted in the Forest Plan is implemented and simulated for 100 years. The resulting modeled forest conditions (forest type and age structure) are compared to Forest Plan goals and to habitat models for the VNFS. Meeting these Forest Plan goals could be considered a measure of successful restoration. The model results will help answer the question of how long does it take to restore a landscape, and once a base model is built, different strategies can be simulated and compared.

\section{Subsequent Chapters}

The remainder of this document consists of three chapters dealing with research. The research chapters are meant to stand alone, although the theme of restoration ecology and measures of success runs through all of them. Chapter 2 will cover the analysis of witness trees on the MNF gathered from the first land surveys made to grant land to European settlers in the area. Chapter 3 covers the analysis of a stand-level prescribed fire study (Fire-Fence-Gap study) that includes fencing to control browse and snag creation to increase light to the forest floor. The 
response of oak seedlings and saplings and their competitors is the main focus of this chapter. Moving to a broader scale and into higher elevation forests, Chapter 4 presents the model creation and simulation results for red spruce-dominated forests under active management guided by implementing the MNF Forest Plan. 


\section{Literature Cited}

Abrams, M.D. 1992. Fire and the development of oak forests. BioScience 42(5): 346-353.

Albrecht, M.A.; McCarthy, B.C. 2006 Effects of prescribed fire and thinning on tree recruitment patterns in central hardwood forests. Forest Ecology and Management 226: 88-103.

Aldrich, S.R; Lafon, C.W.; Grissino-Mayer, H.D.; DeWeese, G.G.; Hoss, J.A. 2010. Three centuries of fire in montane pine-oak stands on a temperate forest landscape. Applied Vegetation Science 13: 36-46.

Arthur, M.A.; Paratley, R.D.; Blankenship, B.A. 1998. Single and repeated fires affect survival and regeneration of woody and herbaceous species in an oak-pine forest. Journal of the Torrey Botanical Society 125(3): 225-236.

Barnes, T.A.; Van Lear, D.H. 1998 Prescribed fire effects on advanced regeneration in mixed hardwood stands. Southern Journal of Applied Forestry 22(3): 138-142.

Blankenship, B.A.; Arthur, M.A. 2006. Stand structure over 9 years in burned and fire-excluded oak stands on the Cumberland Plateau, Kentucky. Forest Ecology and Management 225: $134-145$.

Brose, P.H.; Van Lear, D.H. 1998. Responses of hardwood advance regeneration to seasonal prescribed fires in oak-dominated shelterwood stands. Canadian Journal of Forest Research 28: 331-339.

Brose, P.H.; Van Lear, D.H. 1999. Effects of seasonal prescribed fires on residual overstory trees in oak-dominated shelterwood stands. Southern Journal of Applied Forestry 23(2): 88-93.

Brose, P.; Van Lear, D.; Cooper, R. 1999a. Using shelterwood harvests and prescribed fire to regenerate oak stands on productive upland sites. Forest Ecology and Management 113: 125-141.

Brose, P.H.; Van Lear, D.H.; Keyser, P.D. 1999b. A shelterwood-burn technique for regenerating productive upland oak sites in the piedmont region. Southern Journal of Applied Forestry 23(3): 158-163.

Burns, R.M.; Honkala, B.H. 1990. Silvics of North America: 1. Conifers; 2. Hardwoods. Agriculture Handbook 654. U.S. Department of Agriculture, Forest Service, Washington, DC. $877 \mathrm{p}$.

Clatterbuck, W.K. 1998. Use of prescribed fire to promote oak regeneration. In: Waldrop, T.A., ed. Proceedings 9th biennial southern silvicultural research conference. General Technical Report SRS-20, USDA Forest Service, Asheville, NC: 315-318. 
Collins, R.J.; Carson, W.P. 2003. The fire and oak hypothesis: Incorporating the influence of deer browse and canopy gaps. In: Proceedings, 13th central hardwood forest conference. General Technical Report NC-234, USDA Forest Service: 44-62.

Day, K.; Berg, J; Brown, H; Crow, T; Morrison, J; Nowacki, G; Puckett, D.; Sallee, R; Schneck, T; Wood, B. 2006. Ecosystem Restoration: A framework for restoring and maintaining the National Forests and Grasslands. Internal Report, USDA Forest Service, Washington, DC. 24 p.

Delcourt, H. R.; Delcourt, P.A. 1997. Pre-Columbian Native American use of fire on southern Appalachian landscapes. Conservation Biology 11(4): 1010 - 1014.

Delcourt, P.A.; Delcourt, H.R. 1998. The influence of prehistoric human-set fires on oakchestnut forests in the southern Appalachians. Castanea 63(3): 337-345.

DeVivo, M.S. 1991. Indian use of fire and land clearance in the southern Appalachians. In: Nodvin, S.C and T.A. Waldrop, eds. Fire and the environment: Ecological and cultural perspectives. General Technical Report, SE-96. USDA Forest Service, Southeastern Forest Experiment Station.

DeWeese, G.D. 2007. Past fire regimes of Table Mountain pine (Pinus pungens Lamb.) stands in the central Appalachian Mountains, Virginia, U.S.A. Ph.D. dissertation, The University of Tennessee, Knoxville. 308 pp.

Elliot, K.J.; Hendrick, R.L.; Major, A.E; Vose, J.M.; Swank, W.T. 1999. Vegetation dynamics after a prescribed fire in the southern Appalachians. Forest Ecology and Management 114: 199-213.

Ellsworth, J.W.; McComb, B.C. 2003. Potential effects of passenger pigeon flocks on the structure and composition of presettlement forests of eastern North America. Conservation Biology 17(6): 1548-1558.

Fesenmyer, K.A.; Christensen, Jr., N.L. 2010. Reconstructing Holocene fire history in a southern Appalachian forest using soil charcoal. Ecology 91(3): 662-670.

Fortney, R.H. 1993. Canaan Valley - An area of special interest within the upland forest region. In: Stephenson, S.L., ed. Upland forests of West Virginia. McClain Printing, Co., Parsons, WV: 47-65.

Hart, A.C. 1959. Silvical characteristics of red spruce (Picea rubens). Station Paper NE-124, USDA Forest Service, Northeastern Forest Experiment Station.

Hessl, A.E; Saladyga, T.; Schuler, T.; Clark, P; Wixom, J. In review. Fire history from three species on a central Appalachian ridgetop. Canadian Journal of Forest Research. 
Hornbeck, J.W.; Kochenderfer, J.N. 1998. Growth trends and management implications for West Virginia's red spruce forests. Northern Journal of Applied Forestry 15(4): 197-202.

Hutchinson, T.F.; Sutherland, E.K.; Yaussy, D.A. 2005. Effects of repeated prescribed fires on the structure, composition, and regeneration of mixed-oak forests in Ohio. Forest Ecology and Management 218: 210-228.

Iverson, L.R.; Hutchinson, T.F.; Prasad, A.M.; Peters, M.P. 2008. Thinning, fire, and oak regeneration across a heterogeneous landscape in the eastern US: 7-year results. Forest Ecology and Management 255: 3035-3050.

Jackson, S.W.; Buckley, D.S. 2004. First-year effects of shelterwood cutting, wildlife thinning, and prescribed burning on oak regeneration and competitors in Tennessee oak-hickory forests. In: Connor, K.F., ed., Proceedings 12th biennial southern silvicultural research conference. General Technical Report SRS-71, USDA Forest Service, Asheville, NC: 231-237.

Kay, C.E. 2007. Are lightning fires unnatural? A comparison of aboriginal and lightning ignition rates in the United States. Tall Timbers Research Station, Tallahassee, FL. In R.E. Masters and K.E.M Galley, eds. Proceedings of the 23rd Tall Timbers Fire Ecology Conference: Fire in grassland and shrubland ecosystems: 16-28.

Keyser, P.D.; Brose, P.; Van Lear, D. 1996. Enhancing oak regeneration with fire in shelterwood stands: Preliminary trials. Transactions 61st North American Wildlife and Natural Resources Conference: 215-219.

Korstian, C.F. 1937. Perpetuation of spruce on cut-over and burned lands in the higher southern Appalachian Mountains. Ecological Monographs 7(1):125-167.

Loftis, D.L. 1990. A shelterwood method for regenerating red oak in the southern Appalachians. Forest Science 36(4): 917-929.

Lorimer, C.G. 1985. The role of fire in the perpetuation of oak forests. University of Wisconsin, Misc Pub. In: Johnson, J., ed., Proceedings of challenges in oak management and utilization: $8-25$.

Mayfield, III, A.E.; Hicks, Jr., R.R. 2010. Abundance of red spruce regeneration across sprucehardwood ecotones at Gaudineer Knob, West Virginia. In: Rentch, J.S.; Schuler, T.M., eds. Proceedings from the conference on the ecology and management of high-elevation forests in the central and southern Appalachian Mountains. 2009 May 14-15; Slatyfork, WV. General Technical Report NRS-P-64. Newtown Square, PA: USDA, Forest Service, Northern Research Station.

Maxwell, H. 1910. The uses and abuses of forests by the Virginia Indians. William and Mary College, Quarterly Historical Magazine. 
McEwan, R.W.; Hutchinson, T.F.; Long, R.P.; Ford, R.D.; McCarthy, B.C. 2007. Temporal and spatial patterns in fire occurrence during the establishment of mixed-oak forests in eastern North America. Journal of Vegetation Science 18: 655-664.

McEwan, R.W.; Dyer, J.M.; Pederson, N. 2010. Multiple interacting ecosystem drivers: towards an encompassing hypothesis of oak forest dynamics across eastern North America. Ecography 33: 1-13.

Nowacki, G.J.; Abrams, M.D. 2008. The demise of fire and "mesophication" of forests in the eastern United States. BioScience 58(2): 123-138.

Nowacki, G.; Carr, R.; Van Dyck, M. 2010. The current status of red spruce in the eastern United States: distribution, population trends, and environmental drivers. In: Rentch, J.S.; Schuler, T.M., eds. Proceedings from the conference on the ecology and management of high-elevation forests in the central and southern Appalachian Mountains. 2009 May 14-15; Slatyfork, WV. General Technical Report NRS-P-64. Newtown Square, PA: USDA, Forest Service, Northern Research Station.

O'Neill, R. V. 2001. Is it time to bury the ecosystem concept? Ecology 82(12): 3275-3284.

Pauley, E.F. 1989. Stand composition and structure of a second-growth red spruce forest in West Virginia. Castanea 54(1): 12-18.

Pielke, R.A. 1981. The distribution of spruce in west-central Virginia before lumbering. Castanea 46: 201-216.

Rentch, J.S.; Schuler, T.M.; Ford, W.M.; Nowacki, G.J. 2007. Red spruce stand dynamics, simulations, and restoration opportunities in the central Appalachians. Restoration Ecology 15(3): 440-452.

Ruffner, C.M.; Abrams, M.D. 1998. Lightning strikes and resultant fires from archival (19121917) and current (1960-1997) information in Pennsylvania. Journal of the Torrey Botanical Society 125(3): 249-252.

Schuler, T.M.; Ford, W.M.; Collins, R.J. 2002, Successional dynamics and restoration implications of a montane coniferous forest in the central Appalachians, USA. Natural Areas Journal 22(2): 88-98.

Schuler, T.M.; McClain, R.W. 2003. Fire history of a ridge and valley oak forest. Res. Pap. NE-724. Newtown Square, PA: USDA, Forest Service, Northeast Research Station.

Shumway, D.L.; Abrams, M.D.; Ruffner, C.M. 2001. A 400-year history of fire and oak recruitment in an old-growth oak forest in western Maryland, U.S.A. Canadian Journal of Forest Research 31: 1437-1443. 
Signell, S.A.; Abrams, M.D.; Hovis. J.C.; Henry, S.W. 2005. Impacts of multiple fires on stand structure and tree regeneration in central Appalachian oak forests. Forest Ecology and Management 218: 146-158.

Society for Ecological Restoration International (SER). 2008. The SER international primer on ecological restoration. Tucson, AZ: SER (website http://www.ser.org/content/ecological_restoration_primer.asp\#3).

USDA. 2006. Monongahela National Forest, land and resource management plan. USDA Forest Service, Monongahela National Forest, Elkins, WV.

USDA. 2007. USDA Forest Service Strategic Plan FY 2007-2012. FS-880. USDA Forest Service, Washington DC.

Wendel, G.W.; Smith, H.C. 1986. Effects of a prescribed fire in a central Appalachian oakhickory stand. Research Paper NE-594, USDA Forest Service.

Westveld, M. 1953. Ecology and silviculture of the spruce-fir forests of eastern North America. Journal of Forestry 51: 422-430.

Whitney, G.G. 1994. From coastal wilderness to fruited plain. Cambridge University Press.

Woods, F.W.; Shanks, R.E. 1959. Natural replacement of chestnut by other species in the Great Smoky Mountains National Park. Ecology 40(3): 349-361. 
Chapter 2. European Settlement-Era Vegetation of the Monongahela National Forest, West Virginia

\begin{abstract}
A database of witness trees from original surveys of what became the Monongahela National Forest is described including an estimate of positional error from the conversion of paper maps to digital format. The final database includes 15,591 corners and 22,107 trees of 49 species from deeds dating from 1752 to 1899 . Significant clustered distributions were found for 26 species when assessed across the study area. White oak was the most frequent witness tree, followed by sugar maple, American beech, and American chestnut and distribution patterns were recognizable across the study area.
\end{abstract}

Across the study area red spruce, hemlock, birch, American beech, magnolia, basswood, sugar maple, ash, northern red oak, and black cherry were all associated with higher elevations. Moderate elevations supported maple, pine, white pine, American chestnut, chestnut oak, and scarlet oak, with American chestnut and chestnut oak more likely on ridges. Low elevation sites with high moisture were more likely to support black walnut, white oak, elm, and sycamore, with white oak, elm, and sycamore associated with valley landforms. Indicator Kriging, using presence-absence data, resulted in probability of occurrence maps for selected species for the study area. Using $30 \%$ probability as a threshold, white oak covered about $27 \%$ of the study area, sugar maple about 17\%, American chestnut about 3\%, and red spruce about $2 \%$.

This snapshot of the forest prior to the industrial logging era can be used to help define restoration goals or objectives, although should be used with caution as it represents one point in time. Other uses of the data base include comparisons to current forest types, input to species extent models, and a temporal analysis of the witness trees themselves.

\title{
Introduction
}

Information on historical forest conditions is sparse for much of the eastern United States due to early settlement and forest clearing by Europeans, and intensive timber harvesting at the turn of the $20^{\text {th }}$ century. Nevertheless, descriptions and quantitative assessments of early forests and grasslands are useful in restoration ecology and can come from many sources such as land survey records, traveler's accounts, and photographs (Whitney 1994). In the absence of large old-growth forests, these historical references are often the best source of information on forest characteristics at the time of European settlement. They can provide clues to Native American influences and other disturbances on the landscape, and can provide an ecological baseline upon which to inform restoration actions. 
Unlike grid-based General Land Office surveys of the Midwest, systematic grid surveys were uncommon in the original colonies. Here, land transfers followed survey methods called metes and bounds. Metes and bounds surveys consist of a series of bearings and distances with trees, posts, rock piles, or natural features recorded to describe corners where bearings changed. Deeds or grants documenting transfer of ownership of a parcel of land also document tree species existing at the time of transfer through these witness trees. Studies of witness trees have been used to describe European settlement-era vegetation of eastern forests (Abrams and Ruffner 1995; Whitney and DeCant 2003; Black and Abrams 2001a; Black and Abrams 2001b; Rentch and Hicks 2005).

Witness tree data give a largely static snapshot of forest composition at the time of early European settlement. Witness tree data have been used to document changes in species composition in current forests (Abrams and McCay 1996; Rentch and Hicks 2005) and other changes in forest conditions (Dyer 2001; Whitney and DeCant 2003; Wang and others 2009) or show consistency in species distribution patterns (Strahler 1972). Relationships between vegetation and site conditions can also be determined through topographic analysis of witness tree locations on the landscape (Abrams and McCay 1996; Black and Abrams 2001a; Wang 2007). Species abundance may also provide information on historic disturbance regimes. When combined with archeological data, witness tree information can also reveal Native American influences on forest composition and structure (Black and others 2006). In sum, this glimpse to the past may be useful understanding past and informing current land management.

Surveyor bias toward certain tree species has been addressed in witness tree studies based on Government Land Office methods (Bourdo 1956; Liu and others 2011) and metes and bounds (Black and Abrams 2001a). Unlike Government Land Office surveys, in metes and bounds surveys the surveyor was not required to scribe information on witness or bearing trees, although blazing of trees likely occurred. As such, a bias toward smooth-barked trees was not likely. Unusual tree species may have been more likely to be used as a witness tree, as was found for Public Land Survey records in Wisconsin (Liu and others 2011), as these would have made the corner easier to re-locate. Longer lived species would likely be chosen over others if available. Ultimately, surveyors chose from species that were present on the site with environmental factors constraining which species could occur at any given survey corner. With this in mind, any mapping of forest types from the analysis of witness tree data are likely to be valid even though 
the trees used to create groupings were not strictly chosen at random by the original surveyor (Manies and Mladenoff 2000). The choice of species to record as a witness tree was made by the surveyor, but site factors invariably affected which species were available to choose from so that even if species bias exists, the mapping of vegetation at a landscape scale should not be significantly affected (Manies and Mladenoff 2000).

Like most eastern states, only a few fragments of old-growth forests documenting early forest composition remain in West Virginia. Often these fragments are found in uncommon ecological settings, a characteristic that may be responsible for the forest escaping harvest. Hence, existing old-growth remnants may under-represent more common ecological settings and forest types. In contrast, witness tree information from land grants and deeds contain a record of forest composition at the time of European settlement across a wide range of ecological settings.

In the 1930s, personnel on the Monongahela National Forest (MNF) obtained the first land grant or deed for parcels that would later become the MNF from county courthouses. The bearings and distances listed in the deeds and land grants were then used by MNF staff to plot the parcels. The individual deeds were referenced by the owner's name, date of deed, and a location number. The resulting parcel maps each covered an area approximately 11,300 ha and overlap slightly. There are 83 of these maps covering the area roughly contained by the proclamation boundary of the MNF. A previous analysis of this dataset was made by Abrams and McCay (1996). In the 1996 study, a portion of the witness tree points were used to characterize species-landform associations of the study area at the level of physiographic section. With current Geographic Information System (GIS) capabilities, the study reported here includes more corners from the 1930s database, analysis by subsection, and a greater number of site variables.

In 2005, the 1930s paper maps were scanned and geo-referenced to be used in a GIS and to preserve the information. The witness tree dataset built from the 1930 s paper maps was explored to answer questions on the composition of European settlement-era forests of the MNF. Specifically, the objectives of this analysis were to: (1) quantify the positional error of this witness tree database, (2) characterize the spatial relationships of the witness trees, (3) characterize the species-site relationships in the early forests, and (4) interpolate among witness corners to provide continuous forest composition from the witness trees. 


\section{Study Area}

The MNF is located in east-central West Virginia (Figure 2.1) and has complex topography as most of the area is located in the Allegheny Mountains and Ridge and Valley physiographic sections, with a small portion in the Northern Cumberland Mountains section (Cleland and others 2007). This complexity results in a variety of landforms and conditions for vegetative diversity. The study area (MNF proclamation boundary buffered by $5 \mathrm{~km}$ ) is approximately 1,014,000 ha, and includes all or portions of the following counties: Barbour, Grant, Greenbrier, Nicholas, Pendleton, Pocahontas, Preston, Randolph, Tucker, and Webster.

This unglaciated area includes the faulted and folded mountains of the Ridge and Valley physiographic section and the uplifted and eroded Allegheny Mountains. The Allegheny Front divides the two physiographic sections, creating a rain shadow effect to the east. Sedimentary rocks of Pennsylvanian, Mississippian, Devonian, Silurian, and Ordovician age underlie the study area. Lithology includes sandstones, shales, siltstones, coal, and limestone. Differing substrates and rates of erosion help create the varied soils and topography of the study area.

The physiographic sections that cover the MNF can be further subdivided to describe the diversity of ecological conditions. Subsections in the study area include: Eastern Allegheny Mountain and Valley (EAMV), Eastern Coal Fields (ECF), Northern High Allegheny Mountain (NHAM), Ridge and Valley (RV), Southern High Allegheny Mountain (SHAM), Western Allegheny Mountain (WAM), and Western Allegheny Mountain and Valley (WAMV) (Cleland and others 2007; Table 2.1). In general, the RV subsection is warm and dry and the WAMV subsection is dry with moderate temperatures. The ECF subsection is warm and moderate in overall moisture. The EAMV subsection is moderate in both moisture and temperature regimes, and the WAM subsection is cool with moderate moisture. The SHAM and NHAM subsections are both wetter and cooler than the other subsections; however, NHAM has the lowest average temperatures while SHAM is more moderate (Table 2.2).

Appalachian oak (Quercus spp.) forest is the primary potential natural vegetation for the RV, EAMV, and WAMV subsections. In contrast, a variable mixture of northern hardwood and red spruce (Picea rubens) is the primary potential natural vegetation for the NHAM and SHAM subsections. The mixed mesophytic type is the primary potential natural vegetation for the WAM and ECF subsections (Cleland and others 2007; Table 2.2). 
The extractive logging boom (and associated fires and soil loss) that reshaped the original forest of West Virginia occurred between 1870 and 1920, reaching a peak in 1909. However, as with earlier European settlement elsewhere, there was small-scale extraction as evidenced by the first sawmill in Tucker County in about 1776 (Stephenson 1993). In the upland counties of the MNF, commercial timber was first removed in areas close to navigable rivers and streams starting in about 1865 (Stephenson 1993) with interstate rail lines reaching the region in the 1850s and 1870s (Lewis 1998). Large-scale forest removal occurred after narrow-gauge railroads were built into the remote upland forest starting around 1884 (Stephenson 1993), with the headwaters of the Greenbrier River in Pocahontas county reached by rail in 1903 (Lewis 1998). Other technologies that made large-scale timber removal possible included the Shay locomotive to navigate the narrow-gauge rail lines and the bandsaw. The largest expansion of sawmills utilizing bandsaws occurred between 1890 and 1910 across West Virginia (Lewis 1998).

The MNF became a National Forest in 1920, although the first land was purchased in 1915 near Parsons, WV under the authority of the Weeks Act of 1911. Under this act, the Secretary of Agriculture was authorized to purchase land to protect navigable streams and to regulate the flow of navigable streams. These lands were to be managed as National Forests by the US Forest Service established in 1905. The purchase of land in West Virginia for a National Forest was spurred by the 1907 flood of Pittsburgh and other towns along the Monongahela River. As cut over forests and over-grazed or farmed lands were purchased, these 'lands that nobody wanted' (Shands and Healy 1977) were protected and restored by a combination of reforestation, fire control, and cessation of poor management practices. Given this history, the ownership pattern of the MNF is fairly fragmented overall with numerous private in- holdings.

\section{Methods}

\section{Witness Tree Locations}

The 2005 digital versions of the 1930s paper maps were used for digitizing the corners of each individual parcel described in a survey or deed. Point features were manually digitized in a GIS (ArcGIS 9.2, ESRI 2002) with corners placed using the 2005 digital map as a visual guide. The 2005 digital maps were of parcel boundaries often with no indication as to corner number or witness tree species. To attribute the point features with the correct tree species, the deed survey 
descriptions were used to determine corner number and tree species, or other marker if any, used to define that corner. Along with tree species, the locator number and date of deed or survey were recorded in the attribute file. A crosswalk of common names used in the deeds and current common and scientific names was used in attributing the corners (Table 2.3). If a species was not noted for a witness tree in the deed (i.e. oak, maple [Acer spp.], birch [Betula spp.]) those witness trees were recorded at the genus level. There is duplication of corners as the deeds themselves reference adjoining parcels. For this database, duplicate points were retained if new species were included as witness trees or the survey was made 10 or more years after the first survey using the corner.

\section{Spatial and Attribute Uncertainty}

Errors in corner location were introduced in the creation of the digital maps and dataset from the hand-drawn paper maps. The 1930s maps were scanned at 200 dpi resolution (jpg format) and geo-referenced using the ESRI ArcGIS georeferencing extension. At least four corners or tie points were used from the scanned maps to reference real world coordinates. Latitude and longitude were noted on most of the 1930s maps, making referencing easier. Referencing of maps continued until root mean squared error rates for all four corners were less than $10 \mathrm{~m}$ (Strager 2008).

Corner points were placed through manual digitizing at a mapping scale of 1:5,000 using many features of the maps as guides and the deed for bearings and distances. The scanned base maps included hand-drawn parcels (pencil lines; error term 1) with most of these highlighted by colored pencil lines (error term 2). For some parcels only the colored pencil line existed on the maps to aid in placing corners. Some tracts were pre-printed on the map (printed lines; error term 3) with corners identified by circles (error term 4) that could also be used for placing corners. All of these map markings introduced positional error when used to place corners in space. In addition, because of the scale used to create the digital point $(1: 5,000)$, the actual digital point was not placed at the exact middle of the guide marker, introducing another error factor (error term 5).

To estimate total positional error, random points were located in the study area in GIS and used to locate map elements to sample. Measurements were made using the ArcGIS measuring tool at a scale of 1:1,000. At the 50 random locations, the widths of colored pencil 
lines, pencil lines, and printed lines were measured. Also at 50 random locations, the diameters of printed circles were measured. The distance from the electronic data point to the center of the base map corner location was measured at 50 random locations. These 50 measurements per map element were not necessarily taken at the same locations because in many areas not all map elements were found at the same location. Error terms 1 through 4 were averaged and divided in half (Kelly and others 2008) since the target placement of the digital corner would have been the center of these map elements. Total error was calculated by summing the squares of each term and taking the square root of the total (equation 1: Kelly and others 2008). Included in this total calculation is an average root mean square error of $9 \mathrm{~m}$ for the georeferencing process (error term 6: Michael Strager, West Virginia University, personal communication).

\section{Equation 1}

Total positional error $=\left(\mathrm{e}_{1}^{2}+\mathrm{e}_{2}^{2}+\mathrm{e}_{3}^{2}+\mathrm{e}_{4}^{2}+\mathrm{e}_{5}^{2}+\mathrm{e}_{6}{ }^{2}\right)^{1 / 2}$

$\mathrm{e}_{1}=1 / 2$ average width of hand-drawn pencil parcel lines

$e_{2}=1 / 2$ average width of hand-drawn colored pencil lines

$\mathrm{e}_{3}=1 / 2$ average width of printed parcel lines

$\mathrm{e}_{4}=1 / 2$ average diameter of printed corner circles

$\mathrm{e}_{5}=$ distance to actual corner from digitized corner

$\mathrm{e}_{6}=9 \mathrm{~m}$, average root mean squared error associated with georeferencing

\section{Landform Bias}

Bias toward certain landforms was noted in similar metes and bounds witness tree datasets (Black and Abrams 2001a). To assess the degree of bias toward landforms in the study area, witness tree locations were compared to a systematic sample (Black and Abrams 2001a). A 0.8-km square grid was created over the study area and the resulting center points tallied by landform. A Chi-square test was used to compare the landform frequencies from the metes and bounds (irregular) survey to the systematic survey. The $0.8-\mathrm{km}$ grid size was chosen for systematic sampling to simulate the GLO grid surveys.

\section{Spatial Analyses}

Species are not located randomly in an area as diverse as the study area. There are ecological drivers that influence where certain species will be found and influence their abundance at any given location (Cooper 1859, Whittaker 1956, Küchler 1964). Ecological data often violate the assumptions of many statistical models by exhibiting spatial autocorrelation 
(Legendre 1993). Spatial autocorrelation is the property of pairs of random variables having values that are more similar (positive autocorrelation) or less similar (negative autocorrelation) than expected for random pairs of observations (Legendre 1993). One benefit of spatial autocorrelation is if spatial autocorrelation is found, then predictions can be made of unknown values using surrounding known values. Spatial heterogeneity is an inherent property of ecosystems, not the product of a random process and for this reason is important to describe (Legendre 1993).

To describe the spatial heterogeneity of the witness tree dataset, the global Morans's statistic was calculated for each species using ArcMap (ESRI 2009). As the MNF covers diverse topography, climate, and soils, the witness trees were stratified by physiographic subsection for analysis (Black and Abrams 2001b). To reduce errors associated with small sample sizes, only those species with more than 50 occurrences were assessed (Whitney 1990). At each witness tree location, a relative frequency of each species was calculated by dividing the number of trees of each species by the total number of trees at the corner (Wang and others 2009). This relative abundance was used as the attribute value for the calculation of spatial autocorrelation by species and subsection.

The global Moran's I measure of spatial autocorrelation is a broad comparison of the study locations to a theoretical random distribution of points and associated values. Moran's I ranges from -1 to +1 with scores near +1 indicating clustered distributions, scores near -1 indicate uniform or dispersed patterns and values close to 0 indicate random patterns (no spatial auocorrelation). The strength of any pattern found in the spatial data is reflected in a calculated Z-score; a 95\% confidence interval was used to determine significance $(\alpha=0.05)$. Clustered distributions represent positive spatial autocorrelation while dispersed patterns indicate negative spatial autocorrelation.

To further describe the spatial dimension of the witness tree dataset, clusters of high and low values and spatial outliers were determined for selected species across the study area through the calculation of Anslein's local Moran's I (Anselin 1995) in ArcMap 9.3.1 (ESRI 2009). As in the global measure of spatial autocorrelation, the relative frequency of each species at the witness tree point was used for the analysis. The study area as a whole was used, as opposed to ecological subsections, because all species showed clustered distributions (positive spatial correlation) when assessed across the study area and to reduce edge effects due to the shapes of 
the subsections. The results of the local Moran's I calculations are Z-scores with high positive scores indicating surrounding points have similar values, either similar high values or similar low values. Low negative Z-scores indicate a statistically significant ( $\alpha=0.05)$ spatial outlier. The Z-scores were used to classify the study points into statistically significant High-High (HH) points or Low-Low (LL) points $(\alpha=0.05)$. Significant spatial outliers were classified as HighLow (HL) if the point has a high value and is surrounded by points with low values, or LowHigh (LH) if the opposite occurs $(\alpha=0.05)$. Euclidian distance was used in all spatial calculations with weights calculated by inverse distance; data were standardized by row totals to account for potential sampling bias.

\section{Indicator Species Analysis}

If patterns in species abundances are determined from the mapping of local spatial autocorrelation, this suggests that underlying variables influencing species distribution could be described. To characterize the associations between tree species and ecophysical characteristics, environmental variables associated with the corner points (buffered by the error distance) were extracted from existing spatial datasets and variables derived from a digital elevation model (DEM). Ecophysical components assessed included topographic roughness, moisture index, aspect, landform, elevation, and soil series.

Topographic roughness is a measure of surface variability that may influence the distribution of species in an area or cause patterns in other physical variables influencing species distributions. For this analysis, a topographic roughness index (TRI) for each cell was calculated as the square root of the sum of squared differences in elevation between a cell and its eight neighboring cells (Riley and others 1999). The moisture index was calculated for each cell as: $\ln ($ flow accumulation +1$) /($ slope +1$)$ (Anderson and others 1998). Elevation, moisture index and topographic roughness index were all calculated as averages around the corner location buffered by the positional error term calculated in Equation 1. These averages were then classified in ArcMap into high, medium, and low based on quantiles. These quantiles of three equal sized divisions of the actual calculated factors are an unbiased way to display and categorize the data. The use of quantiles reduced the likelihood that cutoffs would be biased for any given species' environmental requirements. 
Elevations of 1 to $698.4 \mathrm{~m}$ were classed as low, 698.5 to $872 \mathrm{~m}$ as moderate, and over $872 \mathrm{~m}$ as high elevation. The moisture index ranged from -4.32 to 7.29 with breaks at -2.78 for low/moderate and -1.53 for moderate/high. The TRI ranged from 1 to $224.66 \mathrm{~m}$ with 1 to 32.42 $\mathrm{m}$ as low, 32.42 to $68.13 \mathrm{~m}$ as moderate, and 68.13 to $224.66 \mathrm{~m}$ classed as high TRI.

Aspect, slope, elevation, topographic roughness, and flow accumulation used in the calculation of the moisture index were derived through ArcMap Spatial Analyst from an 18meter DEM of the study area resampled from a 3-m DEM to reduce computing time. Aspect was transformed so that 0 - 22.5 degrees and 337.5 - 360 degrees both resulted in north aspect. Landform and soil series were extracted from existing spatial datasets of the MNF with the corners buffered by the positional error term and all landforms and soil series within that radius tallied. Landform data are from the MNF ecological classification system and were assigned during soil surveys (USDA NRCS 2010a). Landforms include: ridge/peak, bench/plateau, toe slope, side slope, cove, and floodplain/valley. In the original database, slope landforms were separated into generic and mountain with an elevation cut-off for mountain slopes at approximately $300 \mathrm{~m}$. The generic and mountain slope landforms were combined for this analysis as much of the MNF is above $300 \mathrm{~m}$ elevation and elevation was assessed as a separate variable regardless of landform in this analysis. Narrow ridges, broad ridges, saddles, shoulders, knobs, and peaks were combined for the ridge landform category. Side slopes and middle/back slope landforms were combined, and floodplains, newer terraces, older terraces, alluvial fans, valley floors, flats, plains, and valleys also were combined. Soil series were obtained from the MNF soils GIS data layer based on the County soil surveys originally mapped at a scale of 1:20,000. If a soil series described less than $1 \%$ of the corners, it was dropped from the analysis. The original soil series used in the MNF GIS layer were summarized by slope and stoniness categories (Table 2.4). Complexes of soils were summarized by the first soil series listed in the complex; for example Berks-Weikert soils were grouped with Berks soils for this analysis.

The frequency counts of species and ecophysical variables by subsection were analyzed for significance through indicator species analysis with significance tested through Monte Carlo methods (4,999 permutations; $\alpha=0.05)$ in PC-ORD (McCune and Mefford 2006). Categorical ecophysical variables (TRI, moisture index, aspect, landform, elevation, and soils) were used as grouping factors and each witness tree record served as a plot. Overstory tree species with more than 50 occurrences in the study area were included in indicator species analysis. After this 
initial filter, a species had to have 10 or greater occurrences with a site variable to be included in the indicator species analysis. Indicator species analysis combines the species abundance in a given group with the faithfulness of occurrence of a species to a group. The indicator value is the product of the proportional abundance of a species in a group relative to the abundance of that species in all groups and the mean proportion of sample units in each group that contain the species (Dufrene and Legendre 1997; McCune and others 2002). If a species is a perfect indicator of a given group it should always be present in that group and exclusive to that group. Indicator species analysis has been used to describe species-site relationships of Amazonian tree species (Phillips and others 2003), of plants in urban wastelands (Godefroid and others 2007), and is suggested as a useful technique for determining bioindicator species (McGeoch and Chown 1998).

Other assessments of witness trees have used contingency table analysis to determine species-site relationships (Whitney 1990; Abrams and McCay 1996; Black and Abrams 2001a; Black and Abrams 2001b; Dyer 2001; Whitney and DeCant 2003; Wang 2007). Contingency table analysis (a nonparametric method) gives a measure of significant positive or negative association with environmental variables (Haberman 1973; Strahler 1978). However, with small expected values (common for datasets including many site variables and species) the test statistic can give inaccurate results (Dowdy and others 2004) and the test assumes independence of the samples (Maddox and Wisnewski 2008). Since positive spatial autocorrelation is likely present in the data, I chose to use indicator species analysis with significance tested through Monte Carlo methods.

\section{Spatial Interpolation}

To create continuous coverage for selected species, species abundances were converted to presence or absence in the attribute file and indicator kriging (IK) was used to map the probability of occurrence between locations. Indicator kriging has been used on presence/absence witness tree data to create spatially continuous representations of presettlement-era vegetation (Wang 2007), and is the only kriging method appropriate for binary data. Semivariograms were constructed and fitted in ArcMap varying the lag size to reduce the nugget effect. The nugget effect is the amount of variation at the origin (zero distance) of the semivariogram and represents measurement error in the data or variation at a scale finer than 
measured in the model. Sparse data may also lead to a greater than expected nugget effect. Anisotropy, the property of spatial data where differences in values differ by distance and direction between pairs of observations, was found in the distributions of some species and was accounted for in the final models to adjust for the directional influence of the spatial autocorrelation. The directional trend was incorporated into the models by setting the directional search to the direction of the axis of the anisotropic ellipse. Spherical models were fit to the semivariograms because the sample variograms showed linear behavior near the origin (Isaaks and Srivastava 1989). Interpolations were not made for all species; common species (white oak [Q. alba] and sugar maple [A. saccharum]), species of interest for restoration efforts (red spruce and American chestnut [Castanea dentata]), and species with similar site variable associations (based on indicator species analysis) were assessed either alone, or in combination. Using 30\% probability of occurrence as a threshold (Manies and Mladenoff 2000; Wang 2007) the area covered by each species was calculated for the study area.

\section{Results}

\section{Species Abundances}

The full database consists of 15,694 corners representing up to six trees at each corner. Deed dates range from 1752 to 1914 and come from approximately 1,450 individual parcel descriptions. For the subsequent analyses reported here, corners and associated trees dated post1900 were removed. Corners dated post-1900 totaled 103, with an associated 141 trees from five deeds, leaving a total of 15,591 corners representing 22,107 witness trees (Figure 2.2). About $24 \%$ of the corners date to the late 1700s. The greatest numbers of corners were established in the 1840 s and 1850 s at $17.8 \%$ and $29.3 \%$ of total, respectively (Figure 2.3). Some corners in the dataset were not used for analysis as they fell outside the state boundary or on minor subsections.

Forty-nine species (or combined species) were used at least once as witness trees in the deeds (Table 2.3). There were 18 species used as witness trees with too few occurrences to calculate spatial statistics, including pitch/Virginia pine (Pinus rigida/P. virginiana), yew (Taxus canadensis), balsam fir (Abies balsamea), cedar (Juniperus virginiana), willow (Salix spp.), aspen (Populus spp.), sweet/black birch (B. lenta), river birch (B. nigra), oak (no species given), sassafras (Sassafras albidum), holly (Ilex spp.), striped maple (A. pensylvanicum), buckeye (Aesculus spp.), sourwood (Oxydendrum arboretum), hawthorn (Crataegus spp.), witch hazel 
(Hamamelis virginiana), and mulberry (Morus spp.). Spruce-pine and Indianwood witness trees were retained as separate species although a current common or scientific name could not be confidently assigned to them. Spruce-pine appears most often in deeds from Pocahontas County, and appears to refer to either red spruce or hemlock (Tsuga canadensis).

Average species composition varied by subsection with white oak comprising 17 to $32 \%$ of the species used as witness trees in the EAMV, RV, WAMV, and WAM subsections and $19.5 \%$ across the study area (Table 2.5). American chestnut was the most frequent species cited in the ECF subsection (18.4\%), American beech (Fagus grandifolia) in the NHAM (18.2\%), and sugar maple in the SHAM subsection (18.2\%). Across the study area, white oak was the most frequent species, followed by sugar maple (10.3\%), American beech (8.2\%), American chestnut (7.6\%), and basswood (Tilia spp.) (5.6\%). Similarly, species rankings based on species frequency also differed by subsection (Table 2.6). Surprisingly, red maple (A. rubrum) was not cited in any deeds, although it is likely that "maple" refers to red maple. If this is the case, then red maple made up 5.6\% of the witness trees across the study area, and ranked $5^{\text {th }}$ overall. It was most common in the ECF subsection where it comprised $11.5 \%$ of the corner trees, second only to American chestnut.

When summarized as counts of species presence by subsection, similar patterns of species abundances emerge (Table 2.6). White oak was still the most abundant witness tree across the study area and for four of the subsections, ranking fourth (ECF), seventh (NHAM), and ninth (SHAM) in the others. Of those species with greater than 50 occurrences across the study area, white pine (P. strobus) and black locust (Robinia pseudoacacia) were the least common witness trees.

\section{Spatial Error and Landform Bias}

In creating the dataset, the conversion of paper maps to digital format and the manual placement of corner points using the maps as guides introduced positional error. The measurements taken for Equation 1 resulted in an estimate of positional error of $20.9 \mathrm{~m}$ around each witness tree corner. This error estimate was rounded to $21 \mathrm{~m}$ and used as a radius to buffer the corner locations for the calculation of elevation, moisture index, TRI, and tallies of landform and soil series associated with the corners for indicator species analysis. 
The Chi-square comparison of landform frequencies from witness tree locations to systematic sampling showed no difference $(\mathrm{p}=0.575)$. Thus, there is no bias toward a particular landform in this study area and dataset. Both sets of landform frequencies had similar peaks for side slopes, the most common landform in the study area.

\section{Spatial Autocorrelation}

The corner locations themselves, regardless of species, were significantly clustered when spatial autocorrelation was assessed across the study area. Most species showed spatial autocorrelation and displayed clustered patterns across the study area and in the individual subsections. All major tree species were found to have significant clustering (positive spatial autocorrelation) based on Moran's I analysis $(\alpha=0.05)$ in at least one subsection (Table 2.5). In the ECF subsection, white oak was found to have a random distribution. Pine and spruce were found to be randomly distributed in the NHAM subsection. In the RV subsection, black walnut/white walnut (Juglans cinerea/J. nigra) and ash (Fraxinus spp.) were found to be randomly distributed. When considered across the study area as a whole, corners citing scarlet oak (Q. coccinea) and maple as witness trees were found to be randomly distributed.

\section{Local Clustering}

The clustering analysis determined whether points were significantly high-high (HH), low-low (LL), high-low (HL), or low-high (LH), or were not part of any significant cluster type. $\mathrm{HH}$ points are those of high abundance of the species considered surrounded by other high abundance points of that species. The opposite of this are the LL points of low abundance surrounded by other points of low abundance. Spatial outliers are those points determined to be high abundance surrounded by others of low abundance (HL) or low abundance surrounded by high abundance (LH). Overall, points of low species abundance surrounded by other points of low abundance for the same species (LL) were found only for American beech, sugar maple, and white oak (Figure 2.4). The large number of LL points found for white oak would seem to indicate that those areas are the least likely to support white oaks as they are low abundance points surrounded by other low abundance points. These LL points for white oak may also show surveyor bias toward this long-lived species. White pine and pine had similar distributions of high abundance points with nearby high abundance points $(\mathrm{HH})$ with most of those found in the 
EMAV or RV subsections (Figure 2.5). In contrast, there were no HH points for hemlock in the EAMV subsection; $\mathrm{HH}$ points for this species were generally located in the northern half of the study area and at higher elevations (Figure 2.5). Most of the $\mathrm{HH}$ points for red spruce witness trees were located in the SHAM subsection (Figure 2.4). For magnolia species (Magnolia spp.), most HH points were located in the WAM subsection or the border of WAM and SHAM (Figure 2.5). Few $\mathrm{HH}$ points were found for ash, but those found were scattered throughout the study area (Figure 2.6).

The significant LL points for American beech all were found in the RV and EAMV subsections; HH points were found in SHAM, NHAM, and WAM subsections (Figure 2.4). The distribution of local clustering was similar for sugar maple, although no LL clusters appear for sugar maple in the RV subsection (Figure 2.4). Higher concentrations of yellow-poplar (Liriodendron tulipifera) were found in the WAM subsection and very few HH points for this species were found in either SHAM or NHAM subsections (Figure 2.6).

The oaks and hickories (Carya spp.) all had similar distributions of HH points, with few found in the moist and higher elevation, SHAM and NHAM subsections (Figures 2.7 and 2.8). Northern red oak (Q. rubra) is the exception to this, with a more $\mathrm{HH}$ points found in these subsections compared to the other oak species. Analysis of white oak, the most abundant witness tree, shows a distribution of LL points outlining the near absence of white oak in the wetter, colder, and higher elevation subsections (SHAM and NHAM) and part of the WAM subsection (Figure 2.4). Most HH points for white oak are in the EAMV subsection. There were $\mathrm{HH}$ points across the study area for American chestnut, however most were located in the EAMV and WAM subsections (Figure 2.8).

Most $\mathrm{HH}$ points for birch witness trees were found in the higher elevation subsections (Figure 2.9), suggesting that these may have been yellow birch (B. alleghaniensis). For witness trees tallied as simply maple, there were more HH points in the EAMV subsection, and this species did not show a pattern similar to sugar maple suggesting these are red maples (Figure 2.9). Significant $\mathrm{HH}$ or HL points for basswood, butternut, and black walnut witness trees were scattered throughout the study area (Figure 2.10). The cluster of HH points of black walnut in the RV subsection appears unusual. These may represent more mesic conditions along coves and/or stream bottoms within this generally dry subsection. 


\section{Species-Site Associations}

Indicator species analysis showed that across the study area red spruce, hemlock, birch, American beech, magnolia, basswood, sugar maple, ash, northern red oak, and black cherry (Prunus serotina) were all associated with higher elevations, with red spruce, hemlock, birch, and American beech found on toe slopes (Figure 2.11). On the high elevations, Mandy soils on toe slopes were associated with red spruce and birch; hemlock was found on toe slopes on Buchanan soils, while black cherry was associated with Mandy soils on ridges. American beech, magnolia, and basswood were found on Meckesville soils and sugar maple and ash were associated with Belmont soils. Northern red oak witness trees stand out in this high elevation group as being found on southeast aspects, on Cateache soils, and with sites low in moisture. These findings are for witness trees across the study area.

Also across the study area, moderate elevations supported maple, pine, white pine, American chestnut, chestnut oak (Q. prinus), and scarlet oak, with American chestnut and chestnut oak more likely on ridges, Lily soils, with high TRI and low moisture. Low elevation sites with high moisture were more likely to support black walnut, white oak, elm (Ulmus spp.), and sycamore (Plantanus occidentalis), with white oak, elm, and sycamore associated with valleys. Hickory and yellow-poplar witness trees were associated with high TRI, low elevation sites. Black oak (Q. velutina) was associated with Opequon soils, as was black walnut, although the two species differ in associated moisture indices, with black oak found on low-moisture sites. Toe slopes on Lily soils were associated with blackgum (Nyssa sylvatica) witness trees.

No elevation class was significantly associated with spruce-pine, white walnut, and black locust witness trees. Spruce-pine witness trees were more likely on valley landforms in the Potomac soil series with low TRI and high moisture. White walnut was associated with eastfacing toe slopes; black locust with southeast slopes over Laidig soils.

The species-site associations did differ by subsection for some species and ecophysical variables (Figures 2.12 - 2.18). The most frequent witness tree species, white oak, was found on Weikert soils when assessed across the study area but also was associated with Laidig (NHAM subsection; Figure 2.14) and Allegheny (RV subsection; Figure 2.15) soils. Weikert and Laidig soils are geographically associated, forming in place from sandstone, siltstone, and shale while Allegheny soils are alluvial. White oak witness trees were associated with toe slopes in the RV, SHAM (Figure 2.17), and WAMV (Figure 2.18) subsections. Areas of moderate TRI were 
associated with white oak in the EAMV subsection (Figure 2.12) and in the SHAM subsection white oaks were found on areas of low moisture.

Differences in associated soil series were found between the study area as a whole and the RV and WAM (Figure 2.16) subsections for sugar maple witness trees, with Belmont, Calvin, and Meckesville soils determined to be significant. These three soil series are geographically associated with each other. Indicator species analysis determined two other landform associations for sugar maple witness trees; toe slopes in the EAMV subsection and valleys in the ECF subsection (Figure 2.13) along with the association with ridges in the study area overall. The number of differences between analyses by subsection versus study area as a whole was greatest in the EAMV subsection for sugar maple with the species found at low elevations, areas of high moisture, low TRI, and on east-facing toe slopes. Basswood, which was often found in similar areas as sugar maple, was also associated with toe slopes, Belmont soils, and low elevations in the EAMV subsection.

While associated with an upland soil series when assessed across the study area, American beech witness trees were associated with Potomac soils, formed in floodplains, in the RV subsection. In the EAMV subsection, American beech are associated with high-elevation, frigid Mandy soils.

American chestnut witness trees exhibited differing associations with landforms depending on subsection. Landforms supporting American chestnut ranged from ridges (study area), to benches (NHAM), and toe slopes (SHAM). Similarly, chestnut oak witness trees are associated with toe slopes in the SHAM subsection while found on ridges in the study area overall.

Witness trees cited simply as maple differ in soil series with these trees associated with the alluvial Atkins soil in the SHAM subsection and Laidig soils in the study area as a whole. The species (or group of species) represented by the maple witness trees exhibit a range of site associations by subsection from cove (EAMV, ECF) and bench (SHAM) landforms, north (EAMV) and southwest (SHAM) aspects, and areas of high (EAMV) to moderate (ECF) moisture.

Pine (no species given) witness trees were associated with the alluvial Allegheny soils in the study area overall, but with the residual Mandy soil in the SHAM subsection. Also in the SHAM subsection, these witness trees were found to be associated with high elevations. 
Red spruce witness trees were associated with a variety of landforms depending on subsection. This species was found on toe slopes (study area), ridges (RV), and valley (WAM) landforms. Overall, this species was associated with high elevations, but when assessed by subsection, red spruce was associated with low elevations in two subsections (NHAM and WAM).

Northern red and black oak witness trees were found on a variety of landforms based on subsection and followed similar patterns. Both northern red and black oaks were found on ridges in the EAMV subsections, valleys in the ECF subsections, and toe slopes in the RV subsection. Black oaks were also associated with toe slopes in the WAM subsection, while northern red oaks were found on benches when assessed across the study area.

Black cherry witness trees were found on the alluvial soil Atkins and toe slope landforms in the WAM subsection and valley landforms in the EAMV subsection. Across the study area this species was associated with Mandy soils, a high elevation residual soil, and ridge landforms. Similarly, blackgum witness trees were associated with Atkins soils and valley landforms in the ECF subsection, ridges in the EAMV subsection, and Ernest soils (colluvial) in the RV subsection. Ash in the EAMV subsection were associated with Mandy soils of high moisture and low TRI in contrast to the mainly limestone-derived Belmont soils with high TRI associated with this species across the study area.

\section{Indicator Kriging}

Spatial interpolation through IK was calculated for the presence/absence of sugar maple, red spruce, white oak, and American chestnut witness trees and the combinations of sugar maple or basswood, sugar maple or American beech, red spruce or birch, white oak or white pine, American chestnut or chestnut oak, and red, scarlet, black or chestnut oak occurrences. The calculated anisotropy, although varying by species or combination of species, tracked well with the Allegheny Front running northeast-southwest, the known important geological formation in the study area.

The graphical results of IK (Figures 2.19 - 2.28) are consistent with the local clustering results. The lowest probabilities for the occurrence of sugar maple and American beech were found in the EAMV subsection (Figures 2.19 and 2.21). Red spruce was more likely to be found in the cool and moist SHAM and NHAM subsections (Figure 2.22). White oak and American 
chestnut had low probabilities of occurrence in the cool and moist NHAM and SHAM subsections (Figures 2.24 and 2.26). The probability of occurrence for white oak or white pine was greatest in the EAMV subsection (Figure 2.25). When the locations of red, scarlet, black, or chestnut oak locations were interpolated, the lowest probability of occurrence was found in the SHAM and NHAM subsections (Figure 2.28).

When I used $30 \%$ probability of occurrence as a threshold, white oak remained dominant across the study area among single species analyzed at about $27 \%$ of the study area (Table 2.7). Including corners where white pine was recorded increased the area covered by the two species by only $1 \%$. Sugar maple, the next most abundant witness tree based on counts, covered about $17 \%$ of the study area, with coverage increasing to $27 \%$ when basswood points were included or 43\% when American beech points were included (Table 2.7). When assessed alone, American chestnut covered $3 \%$ of the study area, increasing to $10 \%$ when chestnut oak points were included. Red spruce alone was estimated to cover $2 \%$ of the study area; increasing to nearly $10 \%$ when birch points were included. The locations of recorded oak species other than white oak were combined resulting in about $11 \%$ of the study area estimated in these species.

\section{Discussion}

The witness trees listed as pine in the SHAM subsection were likely red spruce. The indicator species analysis showed these trees recorded as pine were significantly associated with ridge landforms of low TRI and high elevation on Mandy soils. Soils in the Mandy series are strongly to extremely acid and have a frigid temperature regime (USDA NRCS 2010b). A frigid soil temperature regime is likely to favor red spruce over hardwoods in undisturbed forests and not likely to support any pine species. The witness trees recorded as spruce-pine were likely hemlock as they were associated with Potomac soils, valley landforms, and high moisture when assessed across the study area. The association of red spruce with low elevation areas in two subsections (WAM and NHAM) may indicate these red spruce witness trees were located in riparian areas.

Although red spruce and balsam fir are often found together, only five balsam fir witness trees were noted in the dataset. It may be that areas most likely to support balsam fir were outside the study area and not well represented. For example, the Canaan Valley area currently supports balsam fir and was known to have provided habitat in the past. This area, however, is 
not well represented by the early deeds (Figure 2.2). Based on the witness trees in the study area, the red spruce-dominated forests are accurately categorized as red spruce-northern hardwood forests.

Red spruce points alone resulted in only $2 \%$ of the study area in greater than $30 \%$ probability of occurrence. This value increased to nearly $10 \%$ when birch points were included in the analysis (Table 2.8; Figure 2.16). The proportion of spruce-dominated forests in the MNF during the period prior to European settlement has been estimated at 10-25\% (USDA 2006). Assuming that at least the majority of the birch corners in the surveys were yellow birch, this IK estimate is at the low end of one made for the MNF based on potential vegetation developed as part of the MNF ecological land type hierarchy (USDA 2006).

Across the study area, white pine witness trees were significantly associated with cove landforms, similar to findings in the presettlement forest of central Pennsylvania (Nowacki and Abrams 1992). This lends support to idea that white pine was restricted to more mesic sites because of periodic understory fires (Abrams 2001). Larger white pines are considered fire resistant because of thick, insulating bark, although white pine seedlings and saplings are killed by understory fire (Carey 1993). In a mixed oak-white pine forest, dominance by either group is controlled by the frequency of understory fires, with longer fire-free periods resulting in white pine recruitment to the overstory (Abrams 2001).

Current difficulties in regeneration of northern red oak on mesic sites makes northern red oak witness tree information important to land managers. Northern red oak witness trees rank $11^{\text {th }}$ in terms of abundance of witness trees across the study area and had its highest ranking of $6^{\text {th }}$ in the RV subsection. Based on indicator species analysis, northern red oaks were found on sites with low moisture, high TRI, at high to moderate elevations, and southeast aspects. The finding that northern red oaks were associated with bench landforms across the study area and in one subsection seems counter to the findings of associations with low moisture sites. The indicator species analysis shows the site variables more likely than chance to be associated with the species, and a broader range of site conditions may be found by exploring the $\mathrm{HH}$ points locations determined from the local clustering analysis. These points could be queried for other site conditions than those assessed in this analysis and field visits could determine other site factors that may be important for regeneration of northern red oaks. 
As was found in witness trees in the central hardwood region of Ohio, Pennsylvania, and West Virginia (Rentch and Hicks 2005), white oak dominated the MNF witness tree record. Unlike the MNF data, at four of five sites in the central hardwoods region, black oak was the next most abundant species (Rentch and Hicks 2005). For the MNF, black oak ranked $13^{\text {th }}$ overall, reaching $5^{\text {th }}$ in the WAMV and RV subsections (Table 2.6). Unlike the central hardwoods analysis, American chestnut ranked $4^{\text {th }}$ across the study area and $1^{\text {st }}$ in the ECF subsection, $3^{\text {rd }}$ in two subsections (WAM and WAMV), and $4^{\text {th }}$ in the EAMV subsection (Table 2.6). Northern red oak was found to be a relatively minor component of the early forest in both studies ranking $11^{\text {th }}$ across the central hardwoods area (Rentch and Hicks 2005) and $11^{\text {th }}$ across the MNF study area reaching a high of fifth place in the NHAM subsection (Table 2.6).

An estimate of early forest composition determined American chestnut made up about $12 \%$ of the forest of West Virginia (Brooks 1910). In the current study, American chestnut comprised $7.6 \%$ of the witness trees across the study area and covered about $3 \%$ of the study area based on IK. Based on the results of indicator species analysis, corners recording chestnut oaks were included with American chestnuts to attempt a better estimate of area for American chestnut through IK. Approximately $10 \%$ of the study area is estimated to include either species (Table 2.8).

The results of indicator species analysis suggest logical groupings of species into forest types. Sugar maple and basswood are similar in their site associations across the study area as a whole and the EAMV subsection. Sugar maple and American beech across the study area were found to be associated with areas of moderate moisture, high elevation, and two geographically associated soils. Birch (likely yellow birch) and red spruce also had many similarities when assessed across the study area, with both found on toe slopes, over Mandy soils, and at high elevations across the study area. Sycamore and elm witness trees, across the study area, were both associated with Atkins soils, valley landforms, with high moisture, and at low elevation. Both species were also found on toe slopes in the WAM subsection.

Chestnut oak and American chestnut often showed the same significant associations of soil, landform, and elevation. Both species were significantly associated with Lily soils on ridges with high TRI, low moisture, and at moderate elevations. White oak stands out in comparison to the other oaks having a significant association with valley landforms and areas of high moisture, while the other oaks, in general, were associated with areas of lower moisture. 
White oak and white pine were associated with Weikert soils and valley or cove landforms across the study area. This same species combination and landform association was found in presettlement forest of the Ridge and Valley Province in Pennsylvania (Nowacki and Abrams 1992).

Elevation does not appear to be a driver in the distribution of tree species in the ECF subsection with only one species, chestnut oak, displaying a significant association with high elevations, and 15 species having no significant association to any elevation class (Figure 2.13). Elevation did not appear to be a significant driver in the distribution of witness trees in the WAMV subsection with indicator species analysis resulting in only three species (birch, sugar maple, and ash) showing a significant association with high elevation sites and one species (yellow-poplar) associated with low elevation sites (Figure 2.18). The ECF subsection is the western-most subsection in the study area and the furthest from the Allegheny Front. This distance from the more mountainous areas may allow for other environmental drivers to have greater influence on species distributions than elevation.

Evidence for limited surveyor bias toward certain species in the MNF witness tree dataset was found in the variety of tree species used as witness trees. Smaller stature trees such as dogwood and serviceberry were documented in the deeds, although not in large numbers. The number of species used by the surveyors (Table 2.3) implies broad knowledge of common trees in the study area. Most telling is the very low occurrence of the generic oak (only 18 occurrences). An overwhelming number of deeds/surveyors used specific oak names in parcel descriptions.

A previous study of witness tree data for the MNF determined that pre-settlement Ridge and Valley section forests were dominated by mixed oak (white oak, chestnut oak, black oak, and northern red oak), pines, American chestnut, and hickory on ridges (Abrams and McCay 1996). Valley floors of the Ridge and Valley section were dominated by white oak, sugar maple, pines, basswood, and hemlock. In the Allegheny Mountains section, presettlement forests were mainly American beech, hemlock, sugar maple, red maple, birch and pine, with American beech, hemlock, and pine on the mountain tops and hemlock, maple, and birch on valley floors.

Unlike Abrams and McCay (1996), the current analysis used subsections instead of sections and more landforms were included. Species trends were generally similar in that oaks were found on drier landscapes and mesic landforms were dominated by northern hardwoods 
(American beech-birch-maple). However, with this current analysis, more detail is available for development of predictive models to assign forest types or species to certain landforms and subsections.

In the 1996 analysis, red spruce witness trees were conspicuously absent, with only one tallied for the Ridge and Valley Province and six in the Allegheny Mountains (Abrams and McCay 1996) compared to the 735 tallied for the study area in the current study. The deed dates for red spruce witness trees assessed in the present study range from 1780 to 1899, with 161 trees dated after 1856, the year of the most recent surveys included in the 1996 study. In the current study, duplicate corners were retained in the dataset if new tree species were added in subsequent surveys. In contrast, the 1996 study covered about 80,000 ha of the MNF and included deeds ranging from 1780 to 1856 . The current study was based on over 15,000 corners and 22,000 trees; the 1996 study included 1,015 trees.

Significant clustering patterns in the distribution of species of witness trees indicate positive spatial autocorrelation. This was not unexpected as vegetation is known to be associated with environmental variables. These spatial patterns need to be considered when creating predictive models (Miller 2005). Using only those species/witness tree locations with clustered distribution should facilitate finding the strongest associations between species occurrences and modeled variables.

The shapes of the subsections, used as analysis area for spatial autocorrelation calculations, may have influenced results. With the major mountain ranges running roughly northeast to southwest, the subsections are generally elongated ellipses often with isolated "tails". Because of these shapes, local clustering analysis was made on the study area and not the subsections.

Indicator Kriging of witness trees from government land office surveys was found not to be useful in estimating the actual area occupied by different vegetation types because the spatial resolution of witness points was too coarse to recreate finer-scale and patchy patterns (Maines and Mlandenoff 2000). As a result, Manies and Mladenoff (2000) recommend that IK be used only to describe areas greater than 10,000 ha. In their study, positive spatial autocorrelation (which IK relies on) was not detected for all species (Manies and Mladenoff 2000). Of the species modeled through IK for the MNF dataset, only scarlet oak showed no spatial autocorrelation at the study area scale. Overall, probabilities of occurrence for most species and 
even combinations of species were low, and none reached 100\% (Figures 2.19-2.28).

Environmental variables could be used with the witness tree locations through co-IK for better interpolation between points.

The potential vegetation mapping for the MNF could be used as a comparison to the results of IK for other species and species combinations. To improve the predictive power of IK, the interpolations could be done for those species showing positive spatial autocorrelation and restricted by subsections. At this scale, the results would still be well within the scale suggested by others as appropriate for interpreting witness tree data (Maines and Mladenoff 2000).

Many parcel boundaries follow valley bottoms and ridges with few corners located on steep side slopes. An analysis of the corners themselves, regardless of species, could be an interesting investigation of land survey patterns across the landscape. When the Moran's I was computed for all corners across all subsections, a significant clustered pattern was determined $(\alpha$ $=0.05)$. Other spatial statistical methods could be used on the data set, either whole or by subsection, to explore scale issues for differences between species.

Only the RV subsection is in Northern Ridge and Valley physiographic section (Cleland and others 2007). Current vegetation patterns in EAMV and the adjacent part of NHAM appear more like the Northern Ridge and Valley section than Allegheny Mountain (Thomas-Van Gundy and others 2007). Another possible use for witness tree species analysis is to determine if preEuropean settlement vegetation patterns in these areas are more similar to Northern Ridge and Valley section than Allegheny Mountain section.

Information presented here could also be used to model past extents of species and compare results to current forests. Even without these models, the witness tree data could be compared to current forests in more general terms such as species composition by subsection. While the witness trees were treated as one point in time for this analysis, the dataset does cover about 150 years. Future analysis of the dataset could include temporal analysis.

The results of this analysis can be immediately used by land managers to describe European settlement-era forests and aid in determining if restoration goals are appropriate given this new information. Managers could also explore site conditions and patterns for individual species through the indicator species analysis and results of local clustering. This analysis has shown that while some species may be abundant in the witness tree record (white oak and sugar maple) their distributions were not homogenous across the study area. Analysis by ecological 
subsection captures the variability in the study area and its influence on the distribution of tree species. 


\section{Literature Cited}

Abrams, M.D. 2001. Eastern white pine versatility in the presettlement forest. BioScience 51(11): 967-979.

Abrams, M.D.; McCay, D.M. 1996. Vegetation-site relationships of witness trees (1780-1856) in the presettlement forests of eastern West Virginia. Canadian Journal of Forest Research 26: 217-224.

Abrams, M.D.; Ruffner, C.M. 1995. Physiographic analysis of witness-tree distribution (17651798) and present forest cover through north central Pennsylvania. Canadian Journal of Forest Research 25: 659-668.

Anderson, M.G.; Merrill, M.D.; Biasi, F.B. 1998. Connecticut River Watershed: Natural communities and neotropical migrant birds, final report. The Nature Conservancy. Boston, MA.

Anselin, L. 1995. Local indicators of spatial association - LISA. Geographical Analysis 27(2): 93-115.

Black, B.A.; Abrams, M.D. 2001a. Influences of Native Americans and surveyor biases on metes and bounds witness-tree distribution. Ecology 82(9): 2574-2586.

Black, B.A.; Abrams, M.D. 2001b. Analysis of temporal variation and species-site relationships of witness tree data in southeastern Pennsylvania. Canadian Journal of Forest Resources 31: 419-429.

Black, B.A.; Ruffner, C.M.; Abrams, M.D. 2006. Native American influences on the forest composition of the Allegheny Plateau, northwest Pennsylvania. Canadian Journal of Forest Research 36: 1266-1275.

Bourdo, E.A. 1956. A review of the general land office survey and of its use in qualitative studies of former forests. Ecology 37(4): 754-768.

Brooks, A.B. 1910. WV Geological Survey, Volume 5: Forestry and Wood Industries. Acme Publishing Co, Morgantown, WV.

Burns, R.M.; Honkala, B.H. 1990. Silvics of North America: 1. Conifers; 2. Hardwoods. Agriculture Handbook 654, U.S. Department of Agriculture, Forest Service, Washington, DC.

Carey, J.H. 1993. Pinus strobus. In: Fire Effects Information System, [Online]. U.S. Department of Agriculture, Forest Service, Rocky Mountain Research Station, Fire Sciences Laboratory. Available: http://www.fs.fed.us/database/feis/ [2011, July 1]. 
Cleland, D.T.; Freeouf, J.A.; Keys, J.E., Jr.; Nowacki, G.J.; Carpenter, C; McNab, W.H. 2007. Ecological Subregions: Sections and Subsections of the Conterminous United States [1:3,500,000] [CD-ROM]. Sloan, A.M., cartog. General Technical Report WO-76. Washington, DC: USDA, Forest Service.

Cooper, J.G. 1859. On the distribution of the forests and trees of North America, with notes on its physical geography. Smithsonian Institution, Annual Report for the year 1858: 246280.

Dowdy, S.M.; Wearden, S.; Chilko, D.M. 2004. Statistics for research, third edition. John Wiley \& Sons, Inc., Hoboken, New Jersey.

Dufrene, M.; Legendre, P. 1997. Species assemblages and indicator species: the need for a flexible asymmetrical approach. Ecological Monographs 67(3): 345-366.

Dyer, J.M. 2001. Using witness trees to assess forest change in southeastern Ohio. Canadian Journal of Forest Research 31: 1708-1718.

ESRI. 2002. ArcMap 9.2. Redlands, CA: Environmental Systems Research Institute.

ESRI. 2009. ArcMap 9.3.1. Redlands, CA: Environmental Systems Research Institute.

Godefroid, S; Monbaliu, D; Koedam, N. 2007. The role of soil and microclimatic variables in the distribution patterns of urban wasteland flora in Brussels, Belgium. Landscape and Urban Planning 80: 45-55.

Haberman, S.J. 1973. The analysis of residuals in cross-classified tables. Biometrics 29: 205220.

Isaaks, E.H.; Srivastava, R.M. 1989. Applied geostatistics. Oxford University Press, New York, New York.

Kelly, M.; Ueda, K.; Allen-Diaz, B. 2008. Considerations for ecological reconstruction of historic vegetation: Analysis of the spatial uncertainties in the California Vegetation Type Map dataset. Plant Ecology 194: 37-49.

Küchler, A.W. 1964. Potential natural vegetation of the conterminous United States. American Geographical Society, Special Publication 36.

Legendre, P. 1993 Spatial autocorrelation: trouble or new paradigm? Ecology 74(6): 16591673.

Lewis, R.L. 1998. Transforming the Appalachian countryside: Railroads, deforestation, and social change in West Virginia, 1880-1920. The University of North Carolina Press, Chapel Hill, NC. 
Liu, F.; Mladenoff, D.J.; Keuler, N.S.; Moore, L.S. 2011. Broadscale variability in tree data of the historical Public Land Survey and its consequences for ecological studies. Ecological Monographs 81(2): 259-275.

Maddox, G.D.; Wisnewski, C. 2008. Contingency tables in land stewardship: evaluating differences among categorical variables. Sound Science White Paper Series \#01, www.sound-science.org.

Manies, K.L.; Mladenoff, D.J. 2000. Testing methods to produce landscape-scale presettlement vegetation maps from the US public land survey records. Landscape Ecology 15: 741754.

McCune, B.; Grace, J.B; Urban, D.L. 2002. Analysis of ecological communities. MjM Software Design, Gleneden Beach, Oregon, USA.

McCune, B.; Mefford, M.J. 2006. PC-ORD multivariate analysis of ecological data, version 5.12. MjM Software, Gleneden Beach, Oregon, USA.

McGeoch, M.A.; Chown, S.L. 1998. Scaling up the value of bioindicators. Trends in Ecology and Evolution 13(2): 46-47.

Miller, J. 2005. Incorporating spatial dependence in predictive vegetation models: Residual interpolation methods. The Professional Geographer 57(2): 169-184.

Nowacki, G.J.; Abrams, M.D. 1992. Community, edaphic, and historical analysis of mixed oak forests of the Ridge and Valley Province in central Pennsylvania. Canadian Journal of Forest Research 22: 790-800.

Phillips, O.L.; Vargas, P.N.; Monteagudo, A.L.; Cruz, A.P.; Zans, M.C.; Sanchez, W.G.; YliHalla, M; Rose, S. 2003. Habitat association among Amazonian tree species; a landscape-scale approach. Journal of Ecology 91: 757-775.

Rentch, J.S.; Hicks, R.R., Jr. 2005. Changes in presettlement forest composition for five areas in the central hardwood forest, 1784-1990. Natural Areas Journal 25:228-238.

Riley, S.J.; DeGloria, S.D.; Elliot, R. 1999. A terrain ruggedness index that quantifies topographic heterogeneity. Intermountain Journal of Sciences 5(1-4): 23-27.

Strausbaugh, P.D.; Core, E.L. 1978. Flora of West Virginia, second edition. Seneca Books, Inc. Grantsville, West Virginia.

Shands, W.E.; Healy, R.G. 1977. The lands nobody wanted: a conservation foundation report. Washington, DC: The Conservation Foundation.

Stephenson, S.L., ed. 1993. Upland forests of West Virginia. McClain Printing Co, Parsons, WV. 
Strager, M. P. 2008. Witness and corner tree mapping for identifying presettlement vegetation conditions in the Monongahela National Forest, West Virginia. Final Report to USDA, Forest Service, Monongahela National Forest. West Virginia University, Morgantown, WV.

Strahler, A.H. 1972. Forests of the Fairfax Line. Annals of the Association of American Geographers 62: 664-684.

Strahler, A.H. 1978. Binary discriminant analysis: A new method for investigating speciesenvironment relationships. Ecology 59(1): 108-116.

Thomas-Van Gundy, M. A.; Nowacki, G. J.; Schuler, T. M. 2007. Rule-based mapping of fireadapted vegetation and fire regimes for the Monongahela National Forest. General Technical Report NRS-12. Newtown Square, PA: USDA Forest Service, Northern Research Station.

USDA Forest Service Fact Sheet red spruce. Undated a. http://128.104.77.230/TechSheets/SoftwoodNA/pdf_files/picearubeng.pdf. Last accessed 24 April 2008.

USDA Forest Service Fact Sheet eastern hemlock. Undated b http://128.104.77.230/TechSheets/SoftwoodNA/pdf_files/tsugacanadensiseng.pdf. Last accessed 24 April 2008.

USDA. 2006. Monongahela National Forest, final environmental impact statement for forest plan revision. USDA Forest Service, Monongahela National Forest, Elkins, WV.

USDA NRCS. 2010a. National Soil Survey Handbook, title 430-VI. Available online at: http://soils.usda.gov/technical/handbook/ accessed [09/22/2010].

USDA NRCS, USDA. 2010b. Official Soil Series Descriptions [Online WWW]. Available URL: http://soils.usda.gov/technical/classification/osd/index.html [Accessed 15 September 2010]. USDA-NRCS, Lincoln, NE.

Wang, Y-C. 2007. Spatial patterns and vegetation-site relationships of the presettlement forests in western New York, USA. Journal of Biogeography 34: 500-513.

Wang, Y-C.; Kronenfeld, B.J.; Larsen, C.P.S. 2009. Spatial distribution of forest landscape change in western New York from presettlement to the present. Canadian Journal of Forest Resources 39: 76-88.

Whittaker, R.H. 1956. Vegetation of the Great Smoky Mountains. Ecological Monographs 26(1): 2-80. 
Whitney, G.G. 1990. The history and status of the hemlock-hardwood forests of the Allegheny plateau. Journal of Ecology 78: 443-458.

Whitney, G.G. 1994. From coastal wilderness to fruited plain. Cambridge University Press.

Whitney, G.G; DeCant, J.P. 2003. Physical and historical determinants of the pre- and postsettlement forests of northwestern Pennsylvania. Canadian Journal of Forest Research 33: $1683-1697$. 
Table 2.1 - Ecological subsections of the Monongahela National Forest study area (Cleland and others 2007), area within the proclamation boundary and percentage of total for each.

\begin{tabular}{l|rr}
\hline \multicolumn{1}{c|}{ Subsection } & Total hectares & Percent of study area \\
\hline Eastern Allegheny Mountain and Valley & 161,518 & 16.0 \\
Eastern Coal Fields & 35,078 & 3.5 \\
Northern High Allegheny Mountains & 215,591 & 21.0 \\
Ridge and Valley & 137,390 & 14.0 \\
Southern High Allegheny Mountains & 243,468 & 24.0 \\
Western Allegheny Mountains and Valley & 48,184 & 5.0 \\
Western Allegheny Mountains & 151,138 & 15.0 \\
Other & 21,426 & 2.0 \\
\hline Total & $1,013,793$ & \\
\hline
\end{tabular}

Table 2.2 - Selected subsection climate and potential natural vegetation attributes (Cleland and others 2007). Subsection abbreviations: EAMV = Eastern Allegheny Mountain and Valley, ECF = Eastern Coal Fields, NHAM = Northern High Allegheny Mountain, RV = Ridge and Valley, SHAM = Southern High Allegheny Mountain, WAM = Western Allegheny Mountain, and WAMV $=$ Western Allegheny Mountain and Valley.

\begin{tabular}{l|ccccc}
\hline $\begin{array}{c}\text { Subse } \\
\text { ction }\end{array}$ & $\begin{array}{c}\text { Ave. Annual } \\
\text { Max. Temp. (C) }\end{array}$ & $\begin{array}{c}\text { Ave. Annual } \\
\text { Min. Temp. (C) }\end{array}$ & $\begin{array}{c}\text { Ave. Jan. Min. } \\
\text { Temp. (C) }\end{array}$ & $\begin{array}{c}\text { Ave. Annual } \\
\text { Snowfall (cm) }\end{array}$ & $\begin{array}{c}\text { Ave. annual } \\
\text { precipitation } \\
\text { (cm) }\end{array}$ \\
\hline EAMV & 16.5 & 2.6 & -8.8 & 120.5 & 111.0 \\
ECF & 17.5 & 4.5 & -6.8 & 94.9 & 113.7 \\
NHAM & 14.5 & 2.0 & -9.4 & 263.5 & 128.2 \\
RV & 17.3 & 4.1 & -7.1 & 82.6 & 102.3 \\
SHAM & 15.2 & 2.4 & -9.0 & 224.5 & 138.1 \\
WAMV & 17.1 & 4.3 & -7.0 & 85.6 & 99.7 \\
WAM & 15.1 & 3.0 & -8.8 & 187.8 & 122.2 \\
\hline \multicolumn{5}{r}{} & \multicolumn{7}{c}{ Potential Natural Vegetation (\%) } & \\
& Appalachian & Mixed & Northeastern & Northern & Oak-hickory-pine \\
& oak forest & mesophytic & spruce-fir forest & hardwoods & forest \\
\hline EAMV & forest & 0.0 & 0.2 & 40.9 & 0.0 \\
ECF & 28.9 & 51.7 & 0.0 & 20.2 & 0.0 \\
NHAM & 0.0 & 0.0 & 14.3 & 80.4 & 5.4 \\
RV & 49.1 & 0.0 & 0.7 & 9.2 & 40.9 \\
SHAM & 4.5 & 23.3 & 21.1 & 51.2 & 0.0 \\
WAMV & 85.9 & 1.1 & 0.0 & 13.0 & 0.0 \\
WAM & 26.6 & 38.0 & 0.0 & 35.3 & 0.1 \\
\hline
\end{tabular}


Table 2.3 - Species of witness trees cited in deeds dated 1752 to 1899 on the Monongahela National Forest. Common names used in deeds are cross-walked with current scientific names. A question mark after a scientific name represents uncertainty in the assignment of a scientific name to that name used in deeds.

\begin{tabular}{|c|c|c|}
\hline $\begin{array}{l}\text { Common Name } \\
\text { used in deeds }\end{array}$ & Scientific Name & Stems tallied \\
\hline Pine & Pinus spp. & 1,014 \\
\hline Pitch, yellow, or Virginia pine & P. rigida or $P$. virginiana & 26 \\
\hline White pine & P. strobus & 214 \\
\hline Red spruce, spruce, black spruce, yew pine & Picea rubens ${ }^{1,2}$ & 735 \\
\hline Yew & Taxus canadensis, possibly spruce? & 11 \\
\hline Balsam fir, fir, balsam & Abies balsamea & 5 \\
\hline Spruce-pine & None, likely red spruce ${ }^{3}$ or hemlock ${ }^{1}$ & 379 \\
\hline Hemlock, hemlock-spruce & Tsuga canadensis ${ }^{4}$ & 354 \\
\hline Red cedar, cedar & Juniperus virginiana & 3 \\
\hline Willow & Salix spp. & 1 \\
\hline Aspen, cottonwood & Populus spp. & 1 \\
\hline Butternut, white walnut & Juglans cinerea & 132 \\
\hline Black walnut, walnut & Juglans nigra & 128 \\
\hline Hickory & Carya spp. & 1,008 \\
\hline Hornbeam, ironwood, hophornbeam, Bluebeech & Carpinus caroliniana; Ostrya virginiana & 303 \\
\hline Birch & Betula spp. & 996 \\
\hline Black or sweet birch & B. lenta & 2 \\
\hline River birch & B. nigra & 6 \\
\hline American beech & Fagus grandifolia & 1,927 \\
\hline Chestnut & Castanea dentata & 1,367 \\
\hline Oak & Quercus spp. & 18 \\
\hline White oak & Q. alba & 3,738 \\
\hline Chestnut or rock oak & Q. prinus ${ }^{1}$ & 1,092 \\
\hline Northern red oak & Q. rubra & 732 \\
\hline Scarlet, span, Spanish, or pin oak & Q. coccinea $^{4}$ & 440 \\
\hline Black oak & Q. velutina & 500 \\
\hline Elm & Ulmus spp. & 90 \\
\hline Magnolia, cucumber, elkwood & Magnolia acuminata or M. fraseri ${ }^{6}$ & 260 \\
\hline Yellow-poplar, poplar, tulip tree, tulip & Liriodendron tulipifera $^{1}$ & 455 \\
\hline Sassafras & Sassafras albidum & 6 \\
\hline Sycamore & Plantanus occidentalis & 85 \\
\hline Apple, crab apple, plum, and peach & Malus spp. & 10 \\
\hline Serviceberry, service, service & Amelanchier spp. ${ }^{1}$ & 62 \\
\hline Black or wild cherry & Prunus serotina & 264 \\
\hline
\end{tabular}




\begin{tabular}{|c|c|c|}
\hline $\begin{array}{l}\text { Locust } \\
\text { Holly } \\
\text { Maple } \\
\text { Sugar or hard maple, sugar tree, sugar } \\
\text { Striped maple } \\
\text { Buckeye } \\
\text { Basswood, yellow or white lynn, lin } \\
\text { Blackgum, gum, sour gum } \\
\text { Dogwood } \\
\text { Sourwood } \\
\text { Ash } \\
\text { Hawthorn, white thorn, thorn } \\
\text { Hazel, witch hazel } \\
\text { Indian wood, Indian bitter } \\
\text { Mulberry } \\
\text { Unknown }\end{array}$ & $\begin{array}{l}\text { Robinia pseudoacacia } \\
\text { llex opaca } \\
\text { Acer spp, A. rubrum? } \\
\text { A. saccharum } 1 \\
\text { A. pensylvanicum } \\
\text { Aesculus spp. } \\
\text { Tilia spp. }{ }^{1} \\
\text { Nyssa sylvatica } \\
\text { Cornus spp. } \\
\text { Oxydendrum arboretum } \\
\text { Fraxinus americana } \\
\text { Crataegus spp. } \\
\text { Corylus spp?, Hamamelis virginiana } \\
\text { Maclura pomifera? Based on use as bows } \\
\text { Morus spp. }\end{array}$ & $\begin{array}{r}218 \\
1 \\
1,259 \\
2,235 \\
1 \\
48 \\
903 \\
282 \\
317 \\
10 \\
420 \\
31 \\
6 \\
5 \\
5 \\
2\end{array}$ \\
\hline
\end{tabular}

1 - Strausbaugh and Core $1978 ;{ }^{2}$ - USDA undated a; ${ }^{3}$ - Strahler $1972 ;^{4}-$ USDA undated b; ${ }^{5}$ - Burns and Honkala $1990 ;{ }^{6}-$ Webster- $^{-}$ dictionary.org 
Table 2.4 - Soil series of the Monongahela National Forest used in indicator species analysis. Soils data are from the Monongahela National Forest GIS soils data layer, originally from county soil surveys. For analysis, soil series were grouped by first soil listed in a series or complex and slope and stoniness classes were grouped together.

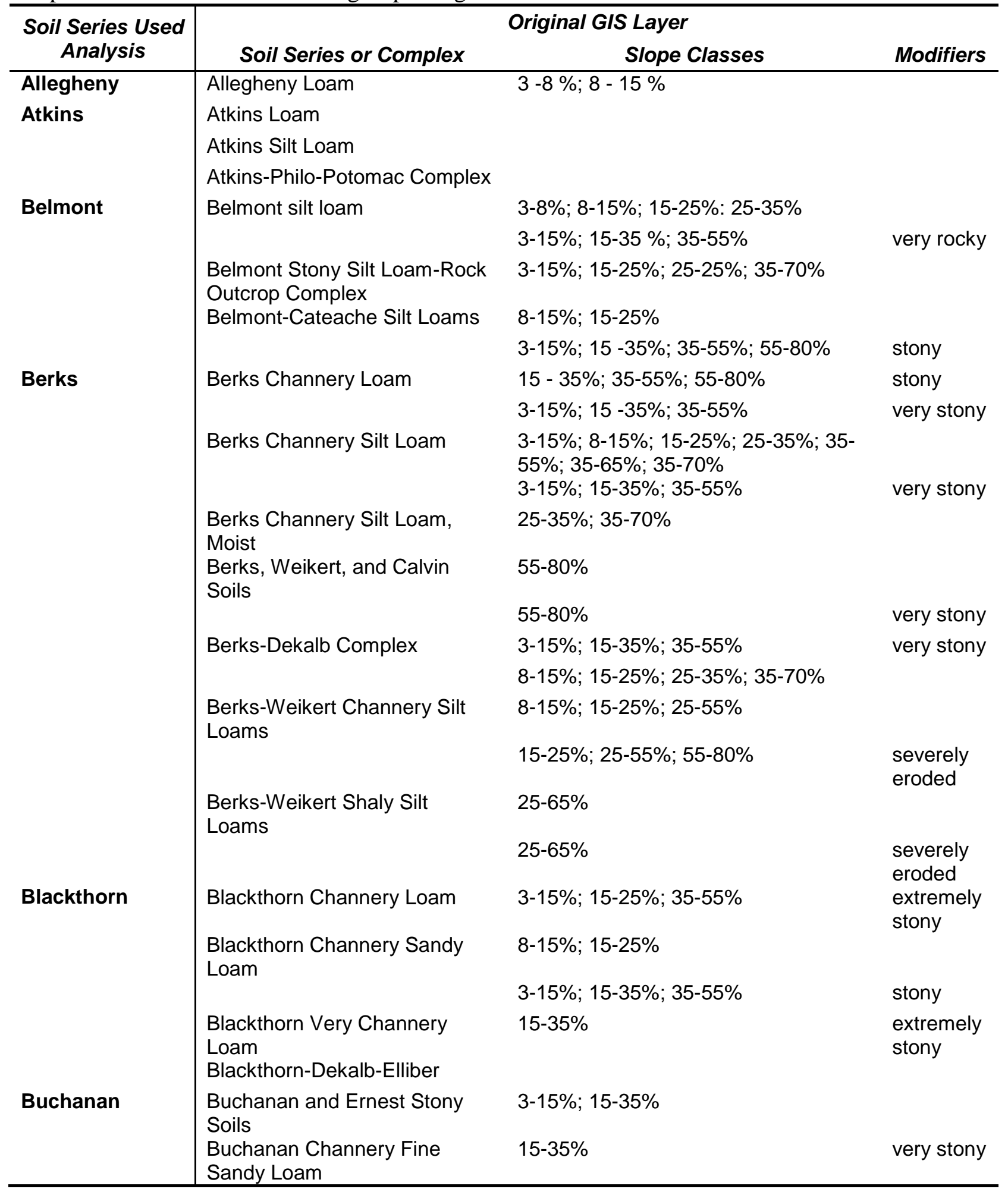




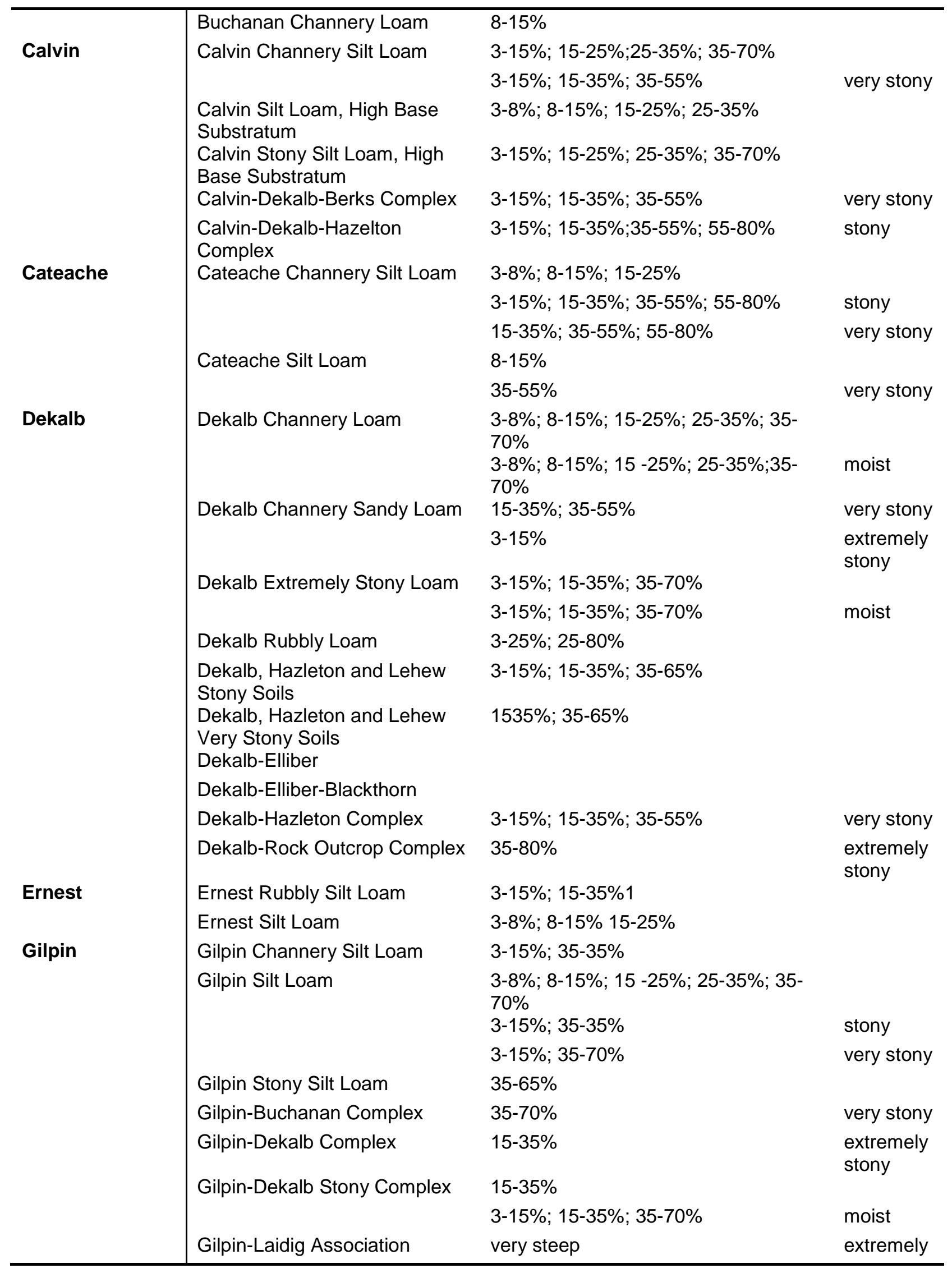




\begin{tabular}{|c|c|c|c|}
\hline \multirow[t]{7}{*}{ Laidig } & Laidin and Buchanan Soils & $3-15 \%$ & $\begin{array}{l}\text { stony } \\
\text { stony }\end{array}$ \\
\hline & Laidig Channery Loam & $8-15 \% ; 15-25 \%$ & \\
\hline & & $15-35 \%$ & stony \\
\hline & & $35-55 \%$ & very stony \\
\hline & Laidig Channery Silt Loam & $\begin{array}{l}3-15 \% ; 15-35 \% \\
8-35 \%\end{array}$ & $\begin{array}{l}\text { extremely } \\
\text { stony } \\
\text { rubbly }\end{array}$ \\
\hline & Laidig Stony Loam & $3-15 \% ; 15-35 \%$ & \\
\hline & Laidig very Stony Loam & $35-50 \%$ & \\
\hline \multirow[t]{2}{*}{ Lily } & Lily Loam & $3-8 \% ; 8-15 \% ; 15-25 \%$ & \\
\hline & Lily Sandy Loam & $3-8 \% ; 8-15 \%$ & \\
\hline Macove & Macove Channery Silt Loam & $\begin{array}{l}3-15 \% ; 3-8 \% ; 8-15 \% ; 15-25 \% ; 15- \\
35 \% \\
3-15 \% ; 15-35 \%\end{array}$ & very stony \\
\hline \multirow[t]{2}{*}{ Mandy } & Mandy Channery Silt Loam & $8-15 \% ; 15-25 \%$ & \\
\hline & & $\begin{array}{l}3-15 \% ; 15-35 \% ; 35-55 \% ; 55-70 \% \\
3-15 \% ; 15-35 \% ; 35-55 \% ; 55-80 \% \\
35-55 \%\end{array}$ & $\begin{array}{l}\text { extremely } \\
\text { stony } \\
\text { very stony } \\
\text { stony }\end{array}$ \\
\hline Meckesville & Meckesville Stony Silt Loam & $3-15 \% ; 15-35 \%$ & \\
\hline \multirow[t]{2}{*}{ Opequon } & Opequon Silt Loam & $\begin{array}{l}3-15 \% ; 15-35 \% ; 35-55 \% ; 35-65 \% ; 55- \\
80 \%\end{array}$ & very rocky \\
\hline & $\begin{array}{l}\text { Opequon-Caneyville Silty Clay } \\
\text { Loams } \\
\text { Potomac Cobbly Loam }\end{array}$ & $15-25 \% ; 25-35 \% ; 35-55 \%$ & $\begin{array}{l}\text { severely } \\
\text { eroded }\end{array}$ \\
\hline \multirow{3}{*}{ Potomac } & Potomac Fine Sandy Loam & & \\
\hline & Potomac Loam & & \\
\hline & $\begin{array}{l}\text { Potomac Very Cobbly Fine } \\
\text { Sandy Loam } \\
\text { Potomac Very Gravelly Fine } \\
\text { Sandy Loam } \\
\text { Potomac Gravelly Loam }\end{array}$ & & \\
\hline \multirow[t]{5}{*}{ Shouns } & Shouns Channery Loam & $15-35 \% ; 35-55 \%$ & rubbly \\
\hline & & $3-15 \% ; 15-35 \% ; 35-55 \%$ & very stony \\
\hline & & $3-15 \%$ & stony \\
\hline & Shouns Silt Loam & $3-15 \% ; 3-8 \% ; 8-15 \% ; 15-25 \%$ & \\
\hline & & $3-15 \% ; 15-35 \% ; 35-55 \%$ & $\begin{array}{l}\text { extremely } \\
\text { stony }\end{array}$ \\
\hline Weikert & Weikert Channery Silt Loam & $8-15 \% ; 15-25 \% ; 25-35 \% ; 25-55 \%$ & \\
\hline
\end{tabular}


Table 2.5 - Mean species composition in percent by ecological subsection, for species with 50 or more occurrences across the study area. The results of global Moran's I analysis are included with highlighted totals denoting species with random distribution patterns and the remaining exhibiting significant clustered patterns $(\alpha=0.05)$.

\begin{tabular}{l|rrrrrrrr}
\hline \multicolumn{1}{c|}{ Species } & EAM & ECF & NHAM & RV & SHAM & WAMV & WAM & $\begin{array}{c}\text { Study } \\
\text { area }\end{array}$ \\
\hline Pine & 9.1 & 0.0 & 1.8 & 8.4 & 4.1 & 4.2 & 0.6 & 4.0 \\
White pine & 3.1 & 0.0 & 0.1 & 0.5 & 0.0 & 0.0 & 0.3 & 0.6 \\
Spruce & 2.5 & 0.0 & 3.1 & 1.1 & 5.9 & 2.7 & 3.5 & 2.7 \\
Spruce-pine & 2.9 & 3.0 & 2.4 & 1.5 & 1.4 & 0.2 & 0.8 & 1.7 \\
Sugar maple & 4.5 & 10.1 & 17.0 & 7.0 & 18.2 & 7.3 & 7.7 & 10.3 \\
Maple & 5.6 & 11.5 & 6.5 & 2.0 & 4.7 & 3.9 & 5.0 & 5.6 \\
Basswood & 2.6 & 4.7 & 5.9 & 3.1 & 6.9 & 1.5 & 2.4 & 3.9 \\
American beech & 1.2 & 8.3 & 18.2 & 0.8 & 17.1 & 2.9 & 9.1 & 8.2 \\
Birch & 1.3 & 1.8 & 6.1 & 1.1 & 9.1 & 1.8 & 4.7 & 3.7 \\
Yellow-poplar & 1.1 & 10.4 & 1.3 & 1.2 & 1.1 & 1.4 & 4.7 & 3.0 \\
Ash & 0.7 & 0.5 & 2.1 & 1.7 & 2.4 & 0.7 & 2.3 & 1.5 \\
Black cherry & 0.7 & 0.2 & 1.8 & 0.2 & 2.2 & 0.6 & 0.5 & 0.9 \\
Magnolia & 0.1 & 0.5 & 2.2 & 0.5 & 1.2 & 0.0 & 2.4 & 1.0 \\
White oak & 32.5 & 10.7 & 5.7 & 28.3 & 3.9 & 38.2 & 17.0 & 19.5 \\
Chestnut oak & 6.1 & 3.0 & 2.3 & 12.4 & 1.0 & 2.2 & 7.6 & 4.9 \\
Black oak & 2.8 & 4.0 & 0.2 & 5.6 & 0.7 & 5.0 & 1.4 & 2.8 \\
Northern red oak & 2.9 & 2.9 & 3.4 & 4.8 & 3.1 & 2.2 & 2.6 & 3.1 \\
Scarlet oak & 0.9 & 0.5 & 2.1 & 2.0 & 0.9 & 3.8 & 4.3 & 2.1 \\
Hickory & 6.1 & 2.2 & 1.3 & 4.5 & 1.7 & 5.1 & 5.3 & 3.7 \\
American chestnut & 6.4 & 18.4 & 4.0 & 4.0 & 4.7 & 6.1 & 9.3 & 7.6 \\
Blackgum & 1.1 & 2.5 & 0.6 & 1.3 & 0.6 & 1.2 & 2.1 & 1.3 \\
Black locust & 0.7 & 0.3 & 0.7 & 0.9 & 1.0 & 1.2 & 0.9 & 0.8 \\
Black walnut/butternut & 0.7 & 0.9 & 1.1 & 2.4 & 1.4 & 1.4 & 0.9 & 1.3 \\
Hophornbeam/hornbeam & 1.1 & 0.2 & 1.3 & 1.2 & 1.7 & 0.8 & 0.4 & 1.0 \\
\hline
\end{tabular}


Table 2.6 - Species frequency by subsection and total study area based on presence only. Only those species (or combination of species) with greater than 50 occurrences across the study area were included. Rankings (1-15) given in parentheses.

\begin{tabular}{|c|c|c|c|c|c|c|c|c|}
\hline Species & $E A M V$ & $E C F$ & NHAM & $R V$ & SHAM & WAMV & WAM & Study Area \\
\hline White oak & $1784(1)$ & $44(4)$ & $129(7)$ & $568(1)$ & $175(9)$ & $351(1)$ & $600(1)$ & 3651 (1) \\
\hline Sugar maple & $292(7)$ & $44(4)$ & $407(2)$ & $177(3)$ & $902(1)$ & $80(2)$ & $295(4)$ & $2197(2)$ \\
\hline American beech & 79 & $36(5)$ & $447(1)$ & 21 & $880(2)$ & $26(10)$ & $377(2)$ & $1866(3)$ \\
\hline American chestnut & $393(4)$ & $76(1)$ & $115(8)$ & $89(8)$ & $226(7)$ & $67(3)$ & $376(3)$ & $1342(4)$ \\
\hline Maple & $386(5)$ & $58(2)$ & $191(3)$ & $59(11)$ & $272(6)$ & $51(6)$ & $223(7)$ & $1240(5)$ \\
\hline Chestnut oak & $366(6)$ & $13(9)$ & $59(12)$ & $255(2)$ & 50 & $22(12)$ & $293(5)$ & $1058(6)$ \\
\hline Hickory & $430(3)$ & $13(9)$ & 39 & $119(7)$ & $102(14)$ & $57(5)$ & $237(6)$ & $997(7)$ \\
\hline Birch & $96(15)$ & $10(11)$ & $171(5)$ & 25 & $483(3)$ & $17(14)$ & $187(9)$ & $989(8)$ \\
\hline Pine & $527(2)$ & 0 & 35 & $169(4)$ & $191(8)$ & $40(8)$ & 22 & $984(9)$ \\
\hline Basswood & $179(11)$ & $23(6)$ & $143(6)$ & $76(9)$ & $352(4)$ & $16(15)$ & 89 & $878(10)$ \\
\hline Northern red oak & $191(9)$ & $15(8)$ & $93(9)$ & $123(5)$ & $167(10)$ & $27(9)$ & $112(12)$ & $728(11)$ \\
\hline Spruce & $153(13)$ & 0 & $91(10)$ & 23 & $290(5)$ & $20(13)$ & $126(11)$ & 703 (12) \\
\hline Black oak & $199(8)$ & $17(7)$ & 7 & $121(6)$ & 31 & $58(4)$ & 56 & 489 (13) \\
\hline Yellow-poplar & 76 & $46(3)$ & 35 & 25 & 52 & 15 & $203(8)$ & $452(14)$ \\
\hline Scarlet oak & 65 & $3(14)$ & $54(14)$ & $44(13)$ & 44 & $46(7)$ & $179(10)$ & 435 (15) \\
\hline Ash & 56 & $3(14)$ & $64(11)$ & $43(14)$ & $147(11)$ & 9 & $95(14)$ & 417 \\
\hline Spruce-pine & $166(12)$ & $11(10)$ & $59(12)$ & 33 & 66 & 2 & 30 & 367 \\
\hline Hemlock & 0 & 0 & $175(4)$ & 7 & 139 (12) & 0 & 6 & 327 \\
\hline Dogwood & $147(14)$ & $8(12)$ & 11 & $46(12)$ & 11 & $24(11)$ & 68 & 315 \\
\hline Hornbeam/hophornbeam & 86 & 1 & $45(15)$ & 34 & $102(14)$ & 8 & 23 & 299 \\
\hline Blackgum & 82 & $10(11)$ & 17 & $35(15)$ & 28 & 13 & $94(15)$ & 279 \\
\hline Black cherry & 44 & 1 & $55(13)$ & 5 & $126(13)$ & 7 & 21 & 259 \\
\hline Black walnut/butternut & 39 & $5(13)$ & 29 & $63(10)$ & 66 & $16(15)$ & 38 & 256 \\
\hline Magnolia & 6 & $2(15)$ & $55(13)$ & 12 & $68(15)$ & 0 & $110(13)$ & 253 \\
\hline Black locust & 61 & $2(15)$ & 19 & 26 & 54 & 15 & 38 & 215 \\
\hline White pine & $191(10)$ & 0 & 2 & 10 & 0 & 0 & 10 & 213 \\
\hline Total & 6094 & 441 & 2547 & 2208 & 5024 & 987 & 3908 & 21209 \\
\hline
\end{tabular}


Table 2.7 - Percent of the study area in selected species based on IK results using $30 \%$ probability of occurrence as threshold.

\begin{tabular}{l|cc}
\hline \multicolumn{1}{c|}{ Species } & Hectares & Percent of study area \\
\hline White oak & 268,230 & 27.2 \\
White oak or white pine & 274,254 & 27.9 \\
Sugar maple & 165,564 & 16.8 \\
Sugar maple or basswood & 262,191 & 26.6 \\
Sugar maple or American beech & 427,207 & 43.4 \\
American chestnut & 27,845 & 2.8 \\
American chestnut or chestnut oak & 102,423 & 10.4 \\
Red spruce & 19,362 & 2.0 \\
Red spruce or birch & 94,074 & 9.6 \\
Northern red, scarlet, black, or chestnut oak & 112,646 & 11.4 \\
\hline
\end{tabular}


Figure 2.1 - Study area location and physiographic subsections. Thicker boundary line is between Northern Ridge and Valley and Allegheny Mountains Sections.

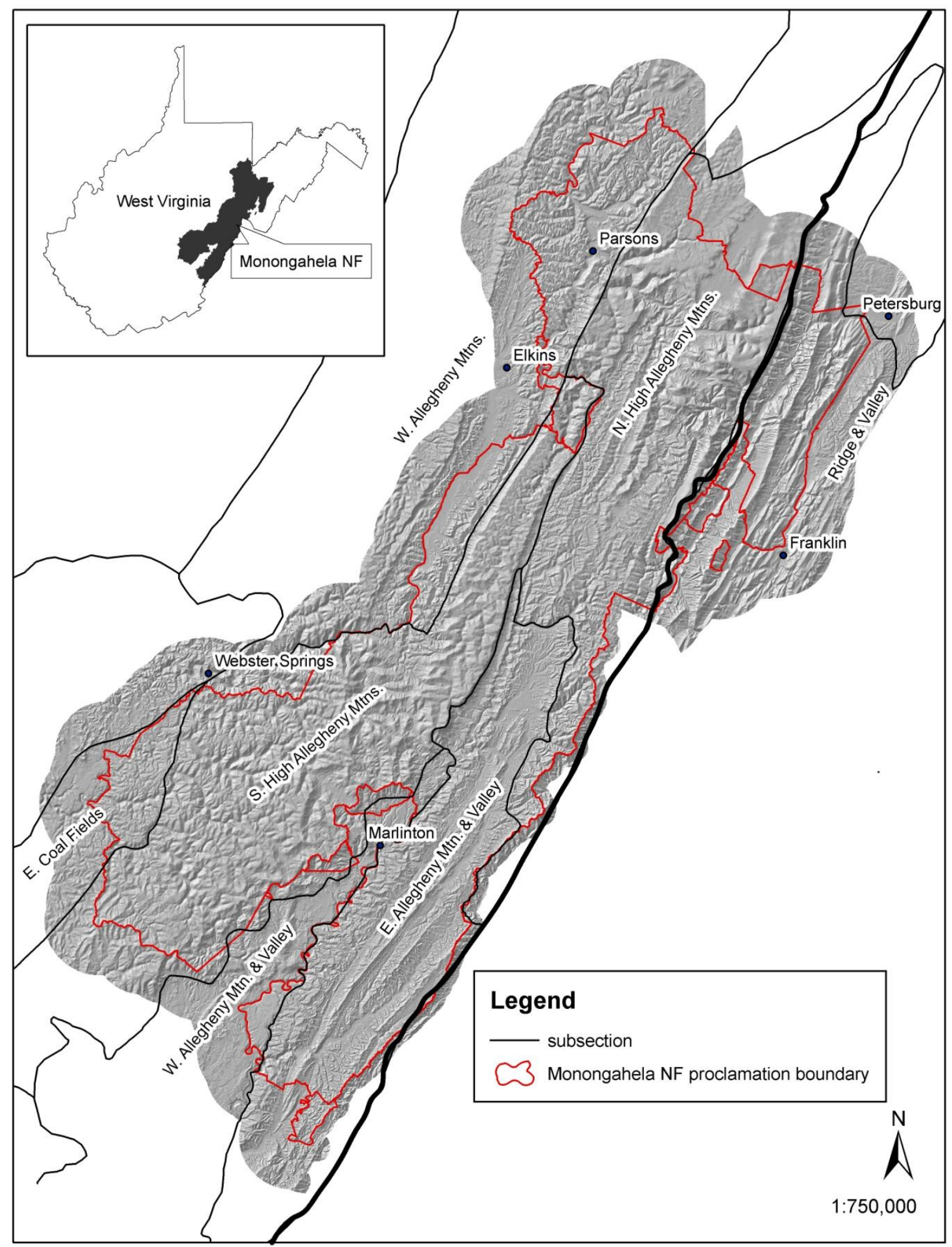


Figure 2.2 - Locations of corners from all deeds in relation to the proclamation boundary of the Monongahela National Forest and this boundary buffered by five kilometers.

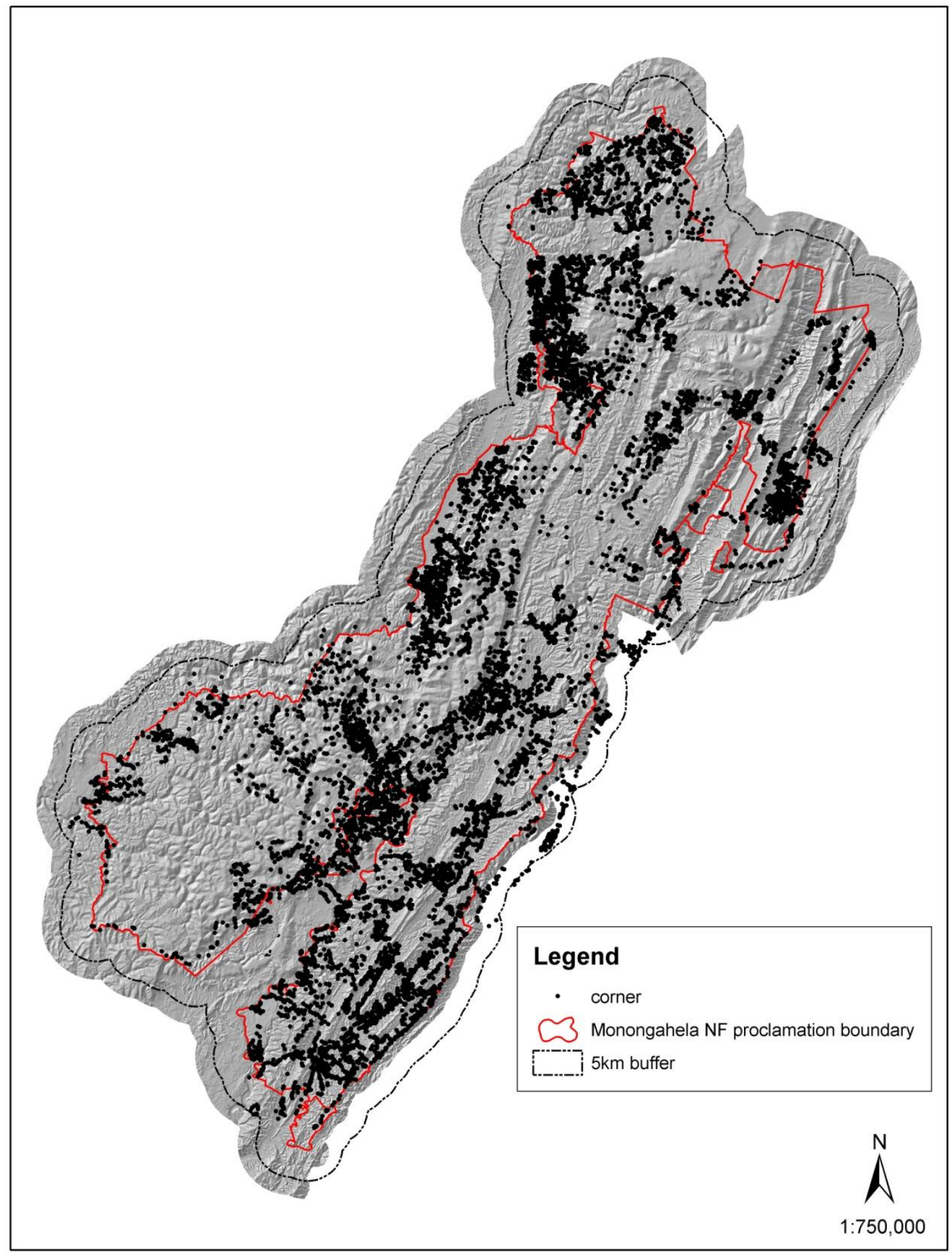


Figure 2.3 - Number of corners per decade based on deed date grouped by decade. Twelve deeds with unknown dates were not included.

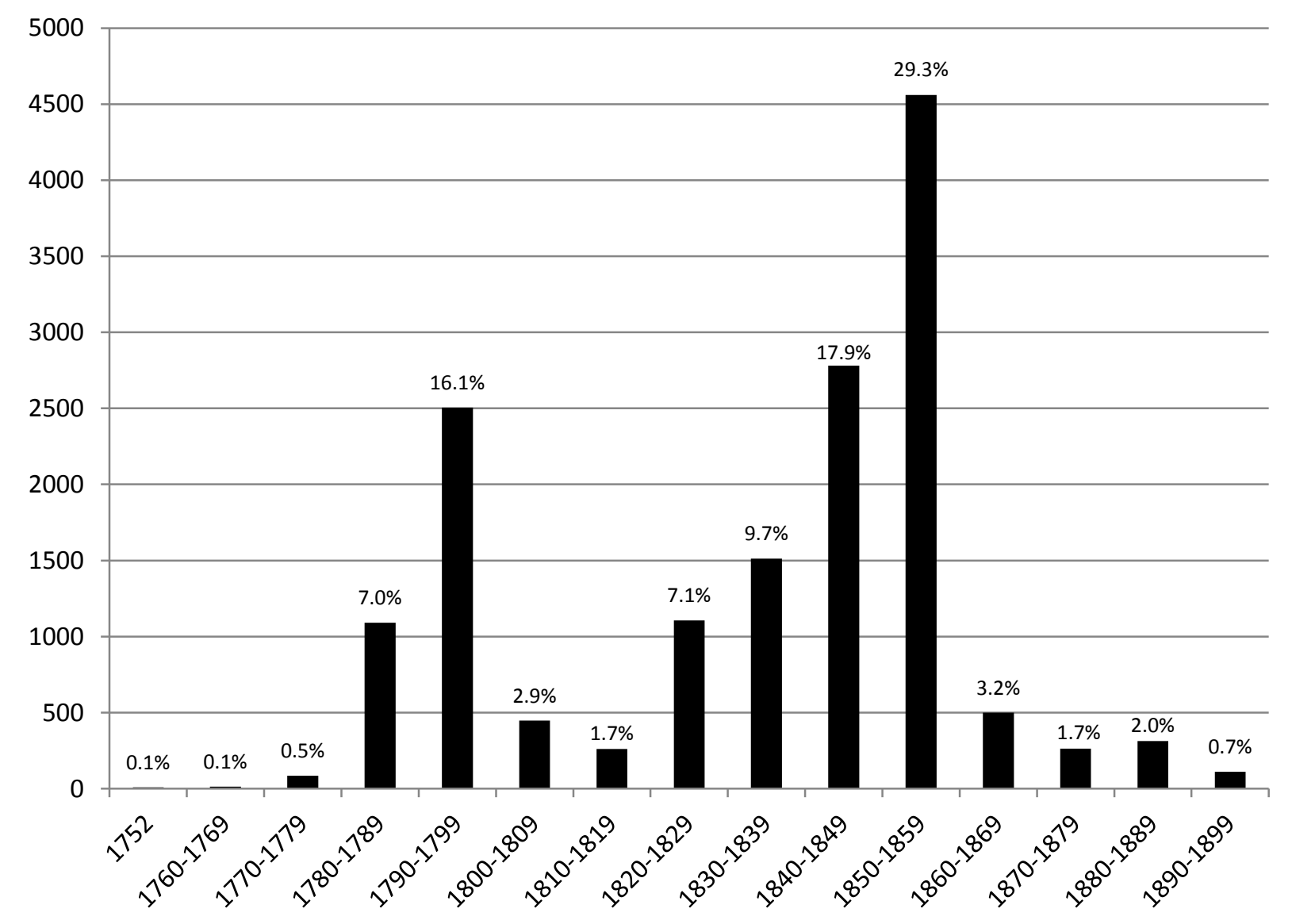


Figure 2.4 - Results of local cluster analysis for beech, sugar maple, white oak, and red spruce witness trees. Analysis results in the identification of hot spots (HH), cold spots (LL), and spatial outliers (HL or LH). Points with no cluster designation are not displayed. Scale for each map is $1: 740,000$.
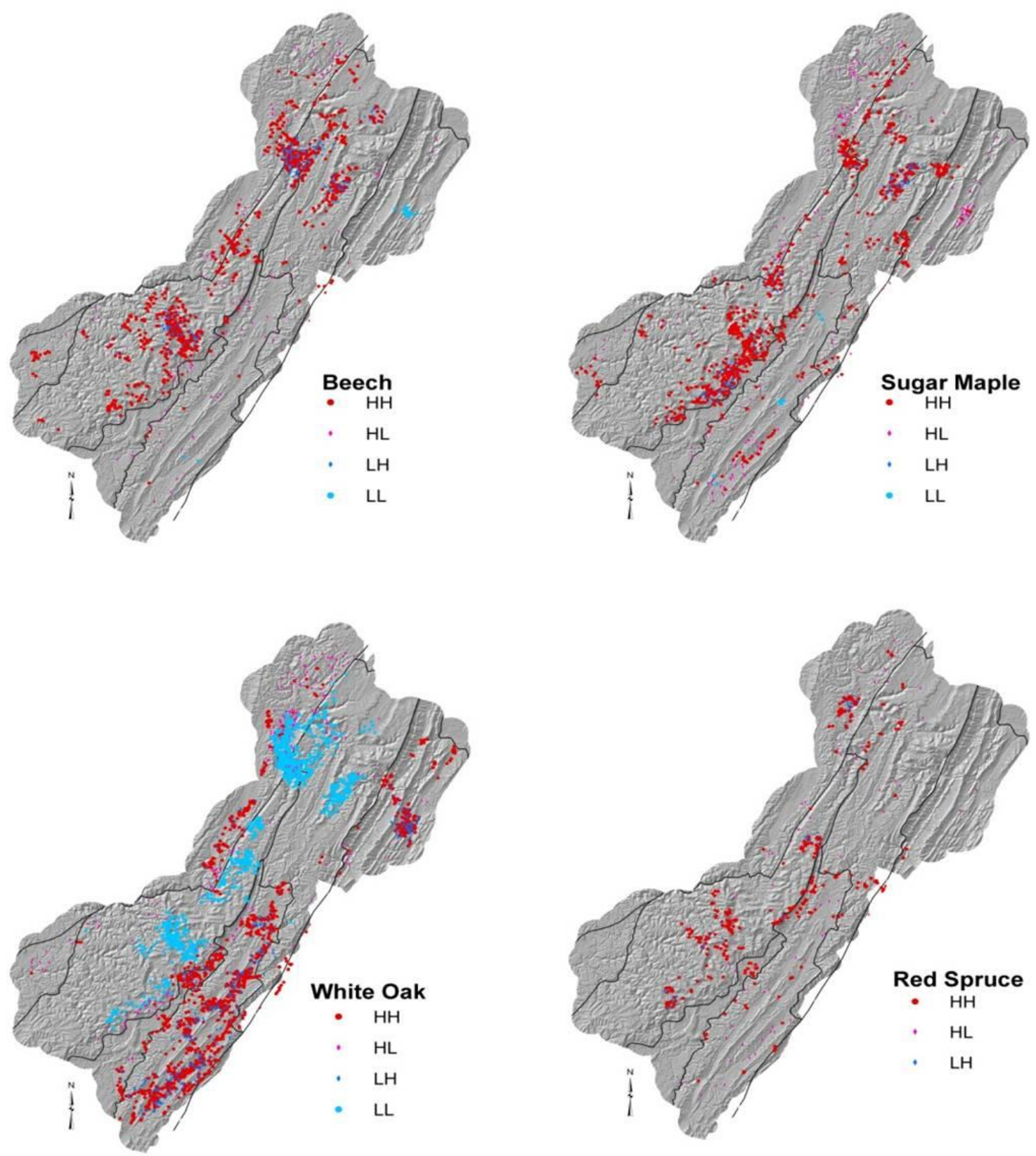
Figure 2.5 - Results of local cluster analysis for white pine, pine, magnolia, and hemlock witness trees. Analysis results in the identification of hot spots (HH), cold spots (LL), and spatial outliers (HL or LH). Points with no cluster designation are not displayed. Scale for each map is $1: 740,000$.
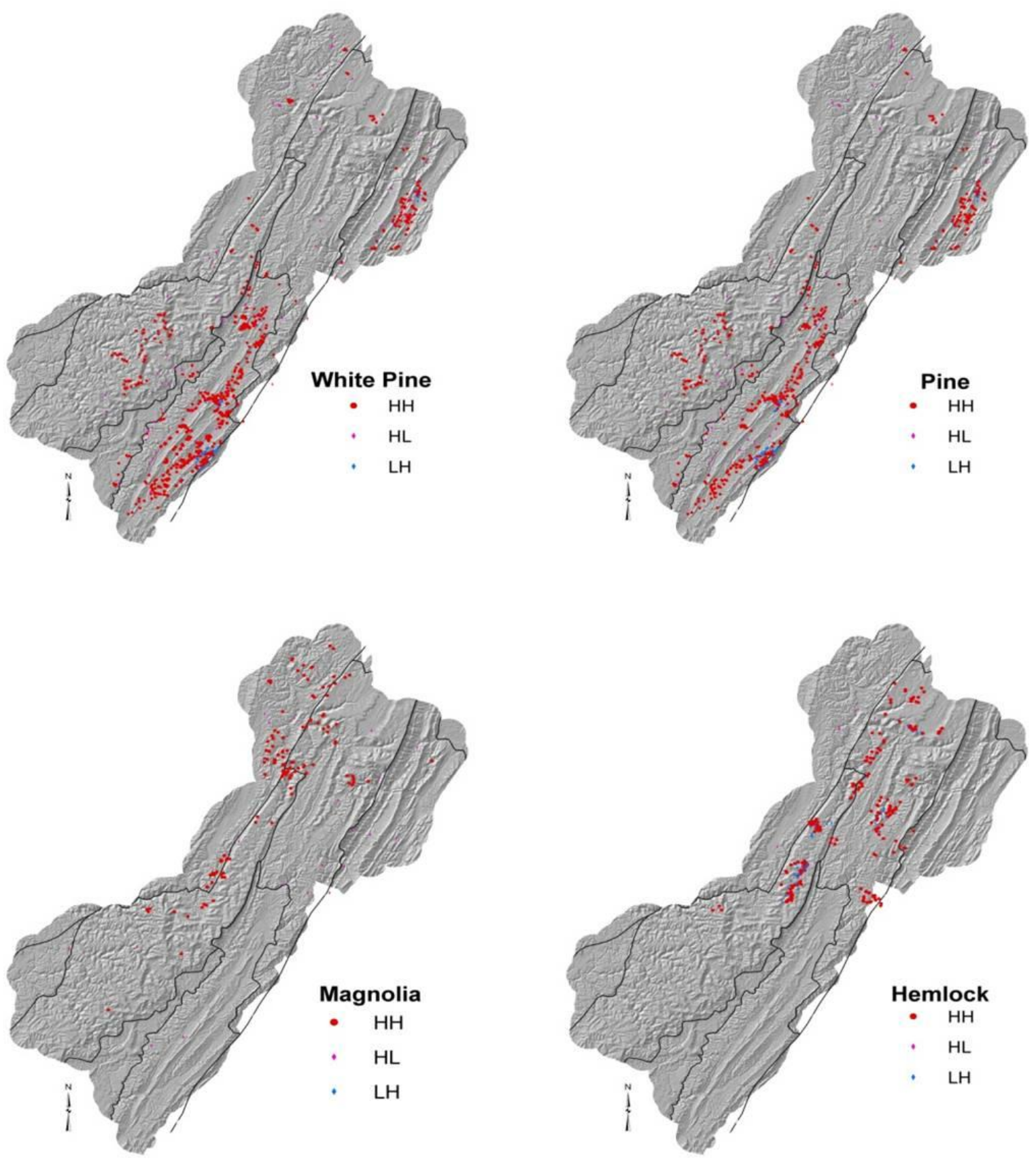
Figure 2.6 - Results of local cluster analysis for ash, yellow-poplar, elm, and sycamore witness trees. Analysis results in the identification of hot spots (HH), cold spots (LL), and spatial outliers (HL or LH). Points with no cluster designation are not displayed. Scale for each map is $1: 740,000$.
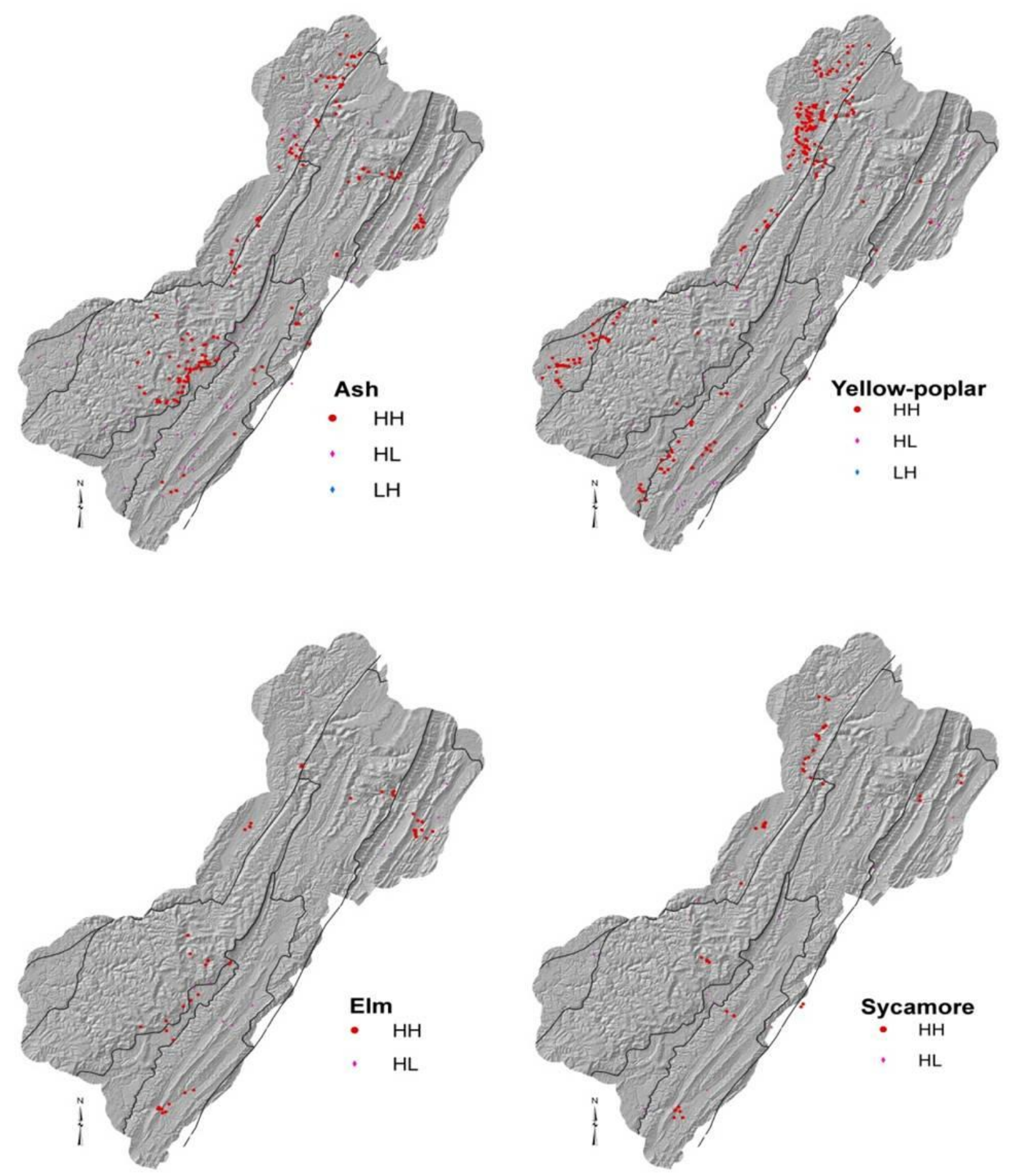
Figure 2.7 - Results of local cluster analysis for chestnut oak, scarlet oak, red oak, and black oak witness trees. Analysis results in the identification of hot spots (HH), cold spots (LL), and spatial outliers (HL or LH). Points with no cluster designation are not displayed. Scale for each map is $1: 740,000$.
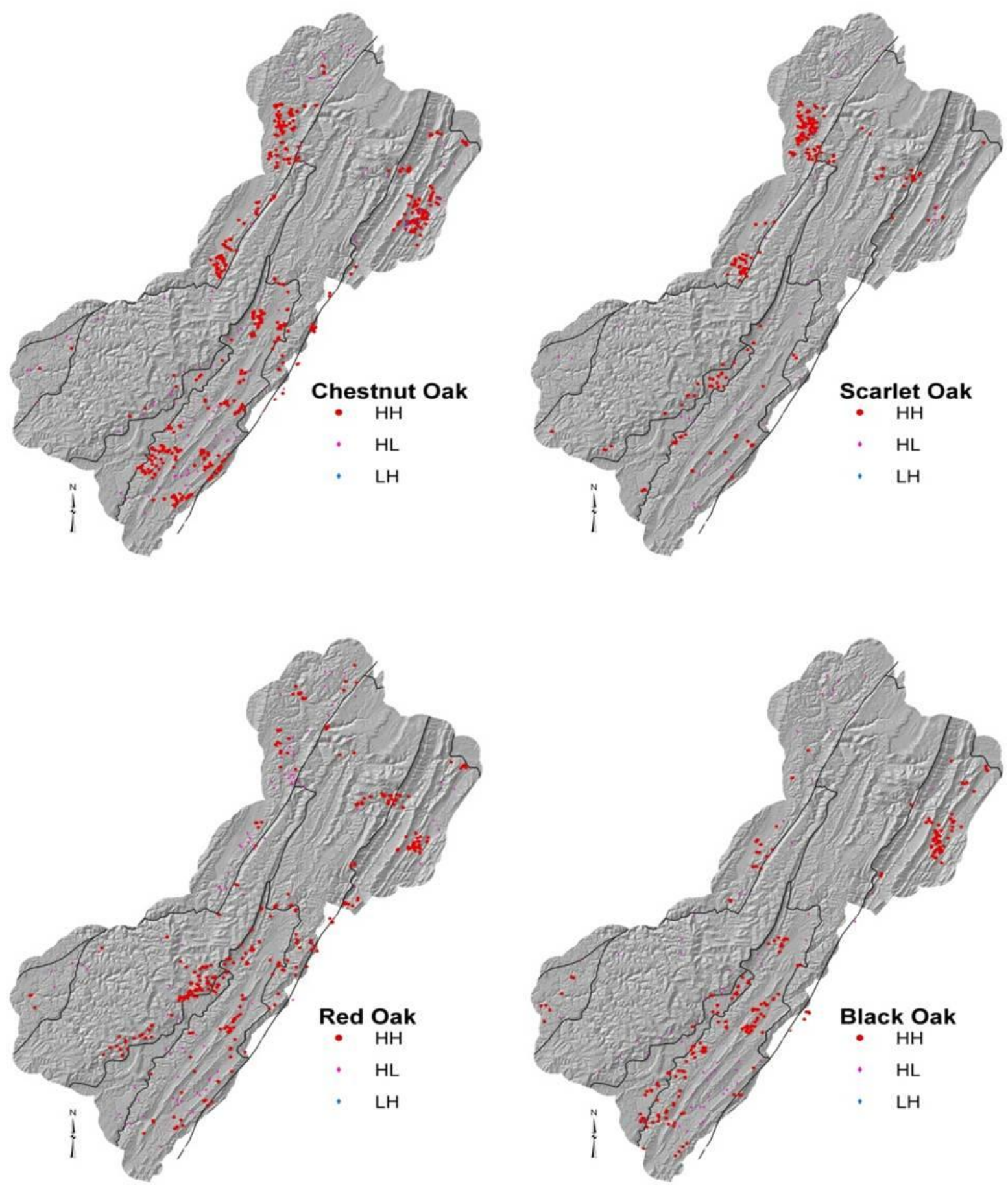
Figure 2.8 - Results of local cluster analysis for hickory, American chestnut, black locust, and blackgum witness trees. Analysis results in the identification of hot spots (HH), cold spots (LL), and spatial outliers (HL or $\mathrm{LH}$ ). Points with no cluster designation are not displayed. Scale for each map is $1: 740,000$.
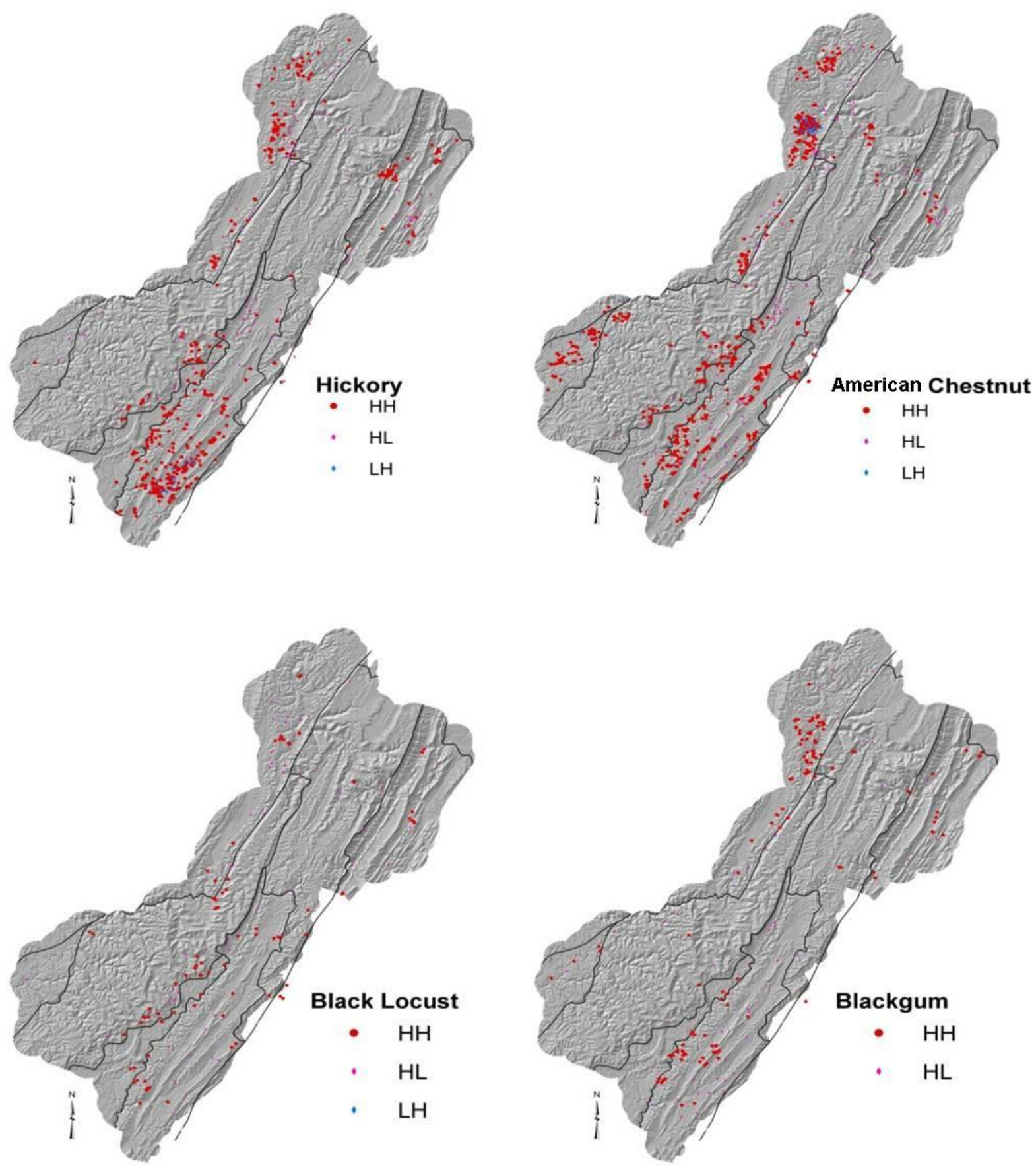
Figure 2.9 - Results of local cluster analysis for black cherry, spruce-pine, birch, and maple witness trees. Analysis results in the identification of hot spots (HH), cold spots (LL), and spatial outliers (HL or LH). Points with no cluster designation are not displayed. Scale for each map is $1: 740,000$.
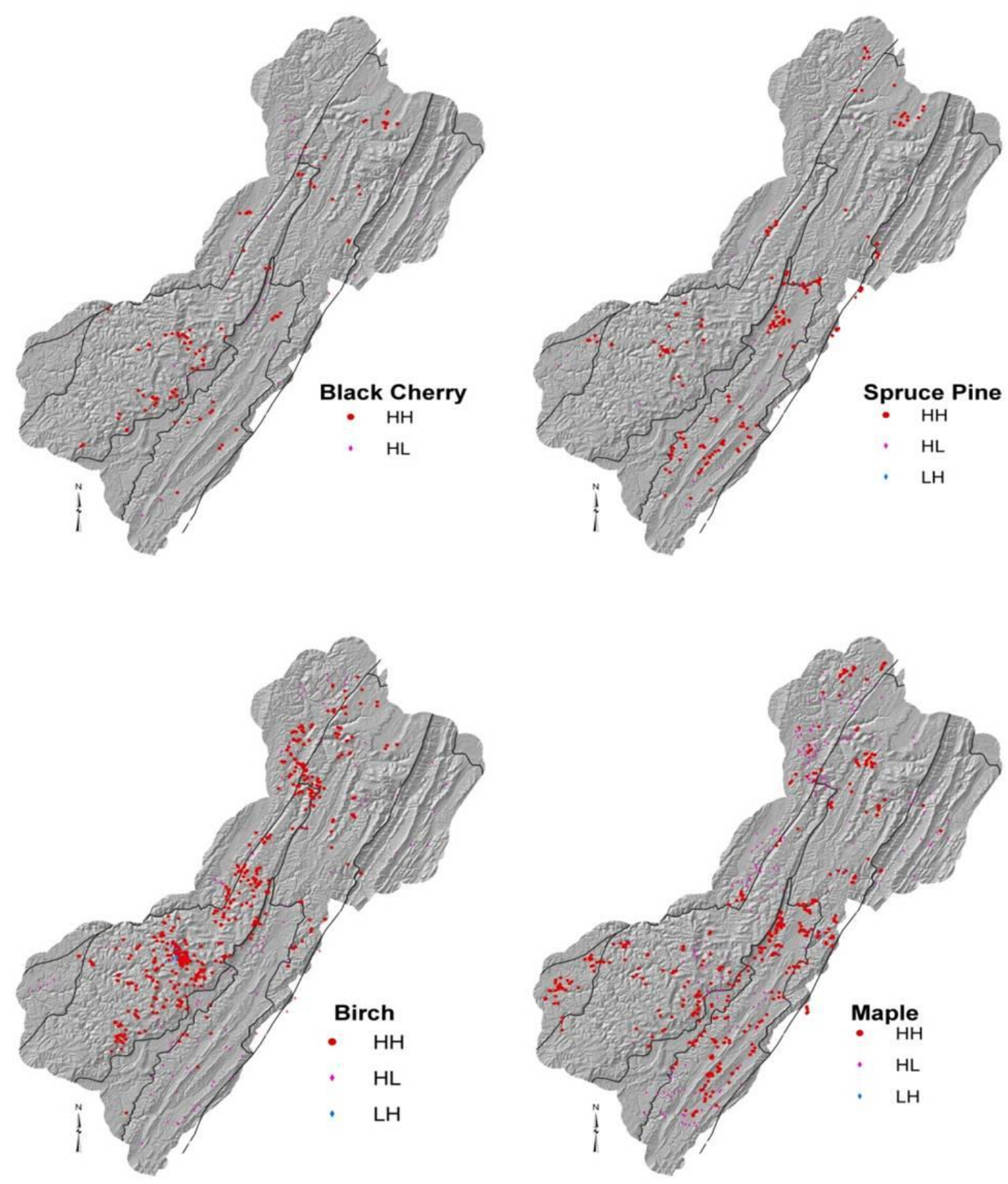
Figure 2.10 - Results of local cluster analysis for basswood, black walnut, and butternut witness trees. Analysis results in the identification of hot spots (HH), cold spots (LL), and spatial outliers (HL or LH). Points with no cluster designation are not displayed. Scale for each map is $1: 740,000$.
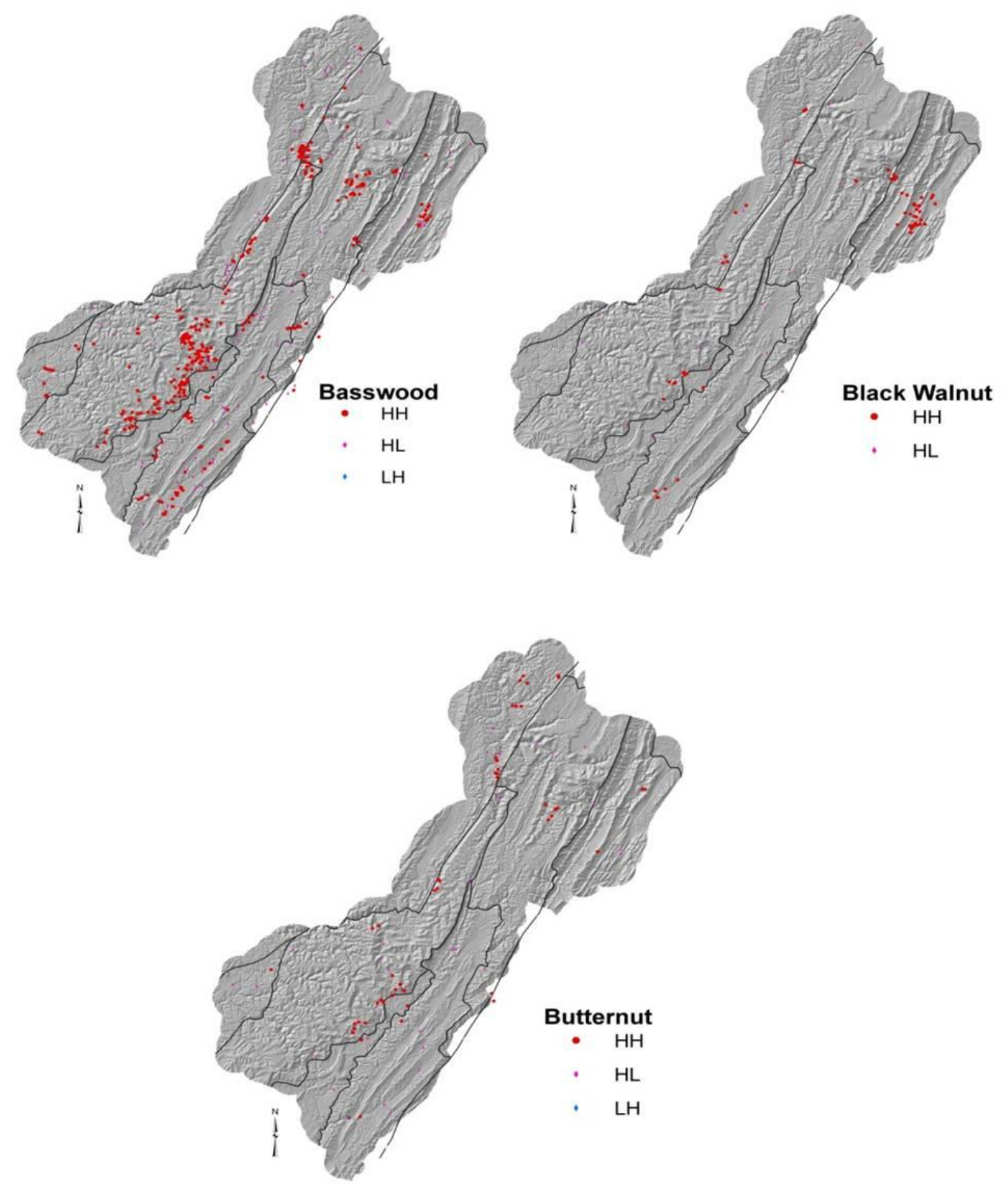
Figure 2.11 - Significant associations $(\alpha=0.05 ; \mathrm{n} \geq 10)$ between tree species and environmental variables (landform, aspect, TRI, moisture index, elevation, and soil series) for the study area (all subsections). Blank (white) cells indicate no significant association for that species-site variable combination. The species are grouped first by their association with elevation class.

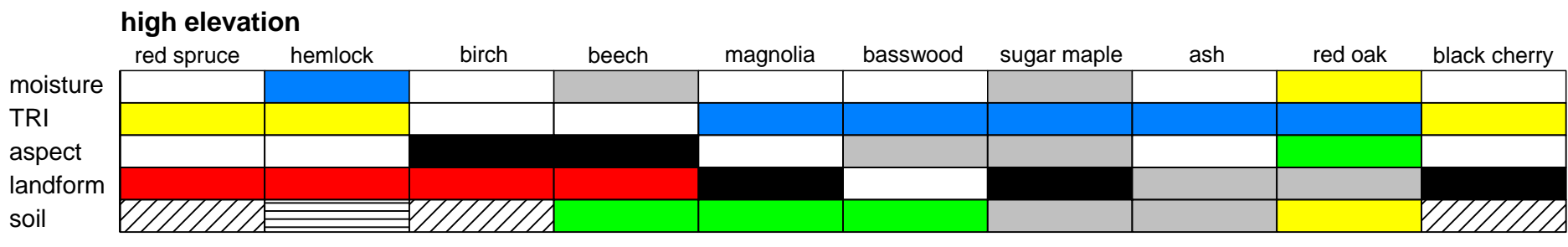

\section{moderate elevation}

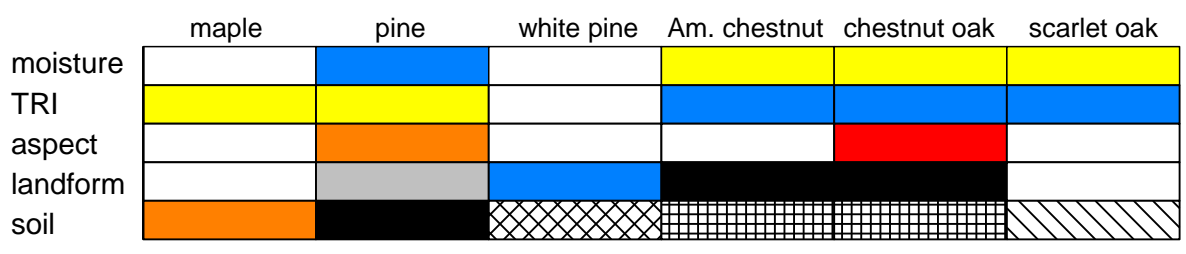

\section{low elevation}

\begin{tabular}{l}
\multicolumn{2}{l}{$\begin{array}{l}\text { black walnut } \\
\text { moisture }\end{array}$} \\
\cline { 2 - 9 } \\
TRI
\end{tabular}

\begin{tabular}{l|l|l|l|}
\multicolumn{3}{l}{ no elevation association } \\
\multicolumn{1}{l}{ spruce-pine } & \multicolumn{1}{c}{ butternut } & \multicolumn{1}{c}{ black locust } \\
\cline { 2 - 4 } moisture & & & \\
\cline { 2 - 4 } TRI & & & \\
\cline { 2 - 4 } $\begin{array}{l}\text { aspect } \\
\text { landform } \\
\text { soil }\end{array}$ & & & \\
\cline { 2 - 4 } & & & \\
\cline { 2 - 4 } & & &
\end{tabular}

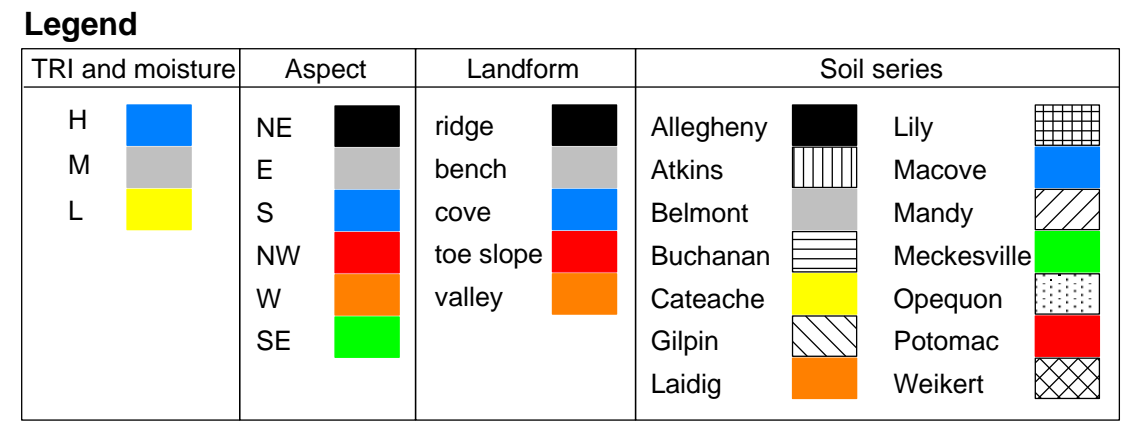


Figure 2.12 - Significant associations $(\alpha=0.05 ; \mathrm{n} \geq 10)$ between tree species and environmental variables (landform, aspect, TRI, moisture index, elevation, and soil series) for the EAMV subsection. Blank (white) cells indicate no significant association for that species-site variable combination. The species are grouped first by their association with elevation class.
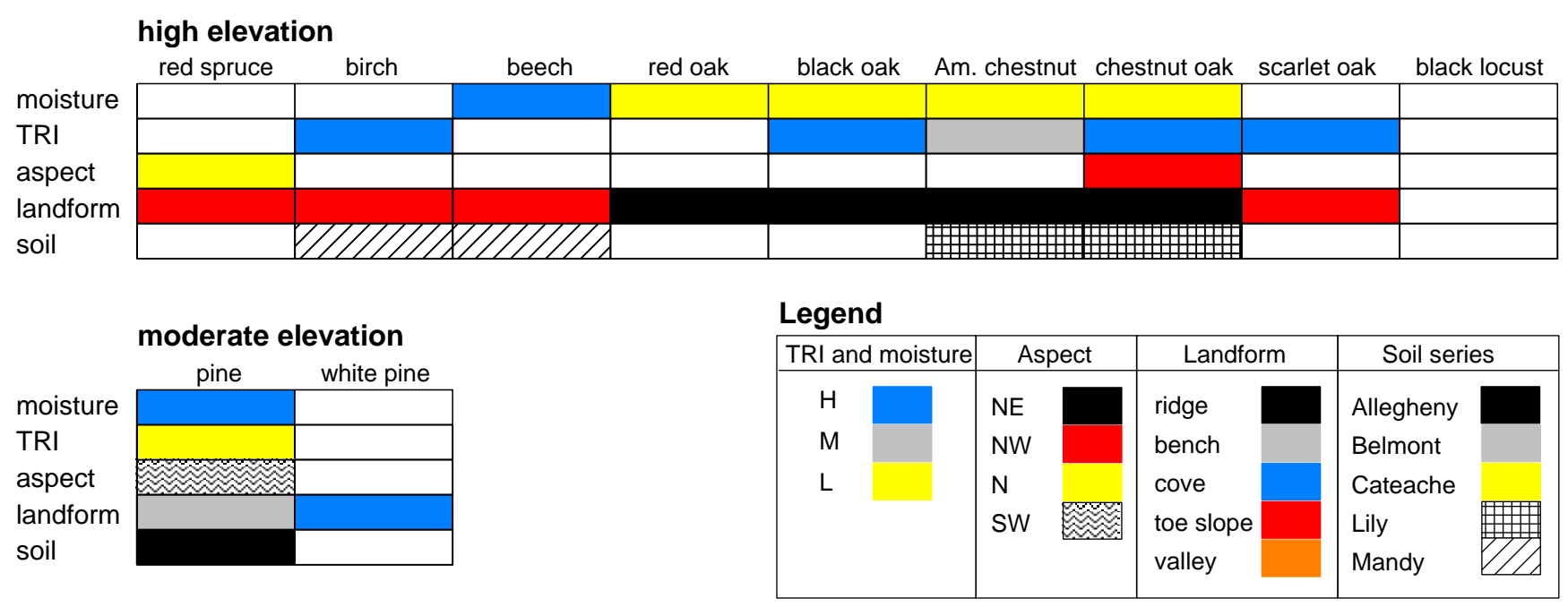

low elevation

\begin{tabular}{|c|c|c|c|c|c|c|c|c|}
\hline & sugar maple & basswood & black walnut & hickory & white oak & elm & sycamore & butternut \\
\hline moisture & & & & & & & & \\
\hline TRI & & & & & & & & \\
\hline aspect & & & & & & & & \\
\hline landform & & & & & & & & \\
\hline soil & & & & & & & & \\
\hline
\end{tabular}

no elevation association

\begin{tabular}{|c|c|c|c|c|c|c|c|}
\hline & black cherry & ash & yellow-poplar & blackgum & maple & spruce-pine & magnolia \\
\hline \multicolumn{8}{|l|}{ moisture } \\
\hline \multicolumn{8}{|l|}{ TRI } \\
\hline \multicolumn{8}{|l|}{ aspect } \\
\hline landform & & & & & & & \\
\hline soil & DEDPDA & 77179 & & 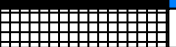 & & & \\
\hline
\end{tabular}


Figure 2.13 - Significant associations $(\alpha=0.05 ; \mathrm{n} \geq 10)$ between tree species and environmental variables (landform, aspect, TRI, moisture index, elevation, and soil series) for the ECF subsection. Blank (white) cells indicate no significant association for that species-site variable combination. The species are grouped first by their association with elevation class.

\begin{tabular}{|c|c|c|c|c|c|c|}
\hline \multirow{2}{*}{\multicolumn{2}{|c|}{$\begin{array}{l}\text { high elevation } \\
\text { chestnut oak }\end{array}$}} & \multicolumn{5}{|l|}{ Legend } \\
\hline & & TRI and moisture & Aspect & Landform & Soils & \\
\hline moisture & & $\mathrm{H}$ & $\mathrm{N}$ & ridge & Atkins & ||ा|| \\
\hline & & M & $\mathrm{s}$ & & Laidig & \\
\hline aspect & & L & SW & side slope & & \\
\hline $\begin{array}{l}\text { landform } \\
\text { soil }\end{array}$ & & & SE & valley & & \\
\hline
\end{tabular}

no elevation association

\begin{tabular}{|c|c|c|c|c|c|c|c|c|}
\hline \multirow{6}{*}{$\begin{array}{l}\text { moisture } \\
\text { TRI } \\
\text { aspect } \\
\text { landform } \\
\text { soil }\end{array}$} & red oak & sugar maple & black oak & blackgum & scarlet oak & basswood & yellow-poplar & \multirow[b]{7}{*}{ birch } \\
\hline & & & & & & & & \\
\hline & & & & & & & & \\
\hline & & & & & & & & \\
\hline & & & & & & & & \\
\hline & & & & & & & & \\
\hline & spruce-pine & ash & butternut & magnolia & black locust & maple & hickory & \\
\hline moisture & & & & & & & & \\
\hline TRI & & & & & & & & \\
\hline aspect & & & & & & & & \\
\hline landform & & & & & & & & \\
\hline soil & & & & & & & & \\
\hline
\end{tabular}


Figure 2.14 - Significant associations $(\alpha=0.05 ; \mathrm{n} \geq 10$ ) between tree species and environmental variables (landform, aspect, TRI, moisture index, elevation, and soil series) for the NHAM subsection. Blank (white) cells indicate no significant association for that species-site variable combination. The species are grouped first by their association with elevation class.

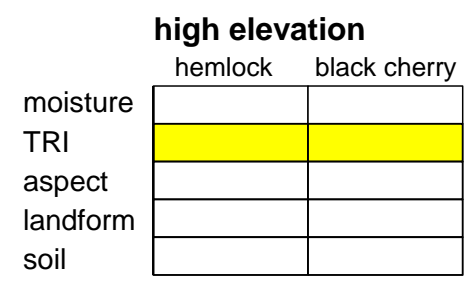

\begin{tabular}{|c|c|c|c|}
\hline TRI and moisture & Aspect & Landform & Soil series \\
\hline $\mathrm{H}$ & NE & bench & Allegheny \\
\hline M & $S$ & & Laidig \\
\hline L & SW & & \\
\hline & $\mathrm{N}$ & & \\
\hline
\end{tabular}

\begin{tabular}{l|l|l|}
\multicolumn{1}{c}{} & \multicolumn{1}{c}{ beech } & \multicolumn{1}{c}{ magnolia } \\
\cline { 2 - 3 } moisture & & \\
\cline { 2 - 3 } TRI & & \\
\cline { 2 - 3 } aspect \\
\cline { 2 - 3 } $\begin{array}{l}\text { landform } \\
\text { soil }\end{array}$ & & \\
\cline { 2 - 3 } & &
\end{tabular}

\section{low elevation}

\begin{tabular}{l|l|l|l|l|l|l|}
\multirow{2}{*}{$\begin{array}{l}\text { moisture } \\
\text { TRI }\end{array}$} \\
\cline { 2 - 7 } \\
\cline { 2 - 7 } $\begin{array}{l}\text { aspect } \\
\text { landform } \\
\text { soil }\end{array}$ & & & & & & \\
\cline { 2 - 7 } & & & & & & \\
\cline { 2 - 7 } & & & & & & \\
\cline { 2 - 7 }
\end{tabular}

no elevation association

\begin{tabular}{|c|c|c|c|c|c|c|c|c|c|c|c|}
\hline & birch & red oak & basswood & sugar maple & black walnut & white oak & Am. chestnut & chestnut oak & scarlet oak & maple & spruce-pine \\
\hline \multicolumn{12}{|c|}{ 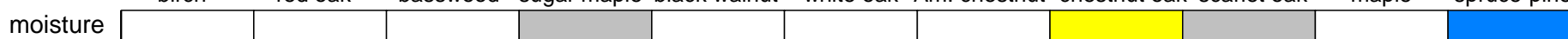 } \\
\hline \\
\hline aspect & & & & & \% & & & & & & \\
\hline landform & & & & & & & & & & & \\
\hline soil & & & & & & & & & & & \\
\hline
\end{tabular}


Figure 2.15 - Significant associations $(\alpha=0.05 ; \mathrm{n} \geq 10)$ between tree species and environmental variables (landform, aspect, TRI, moisture index, elevation, and soil series) for the RV subsection. Blank (white) cells indicate no significant association for that species-site variable combination. The species are grouped first by their association with elevation class.

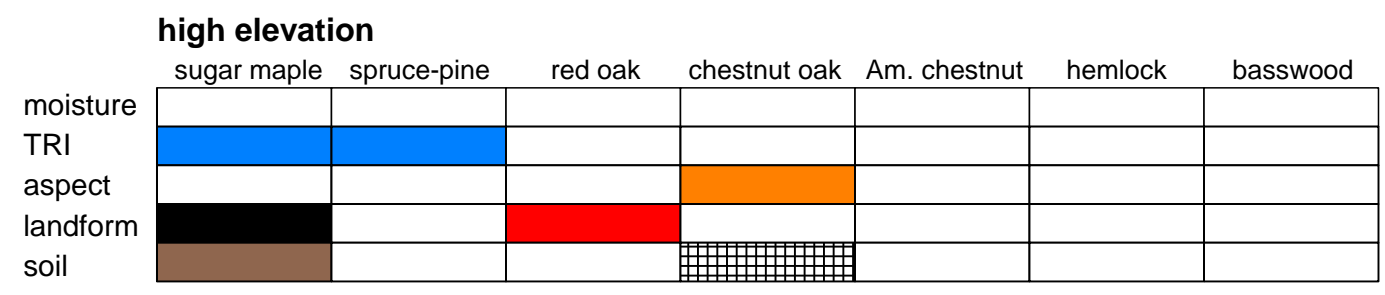

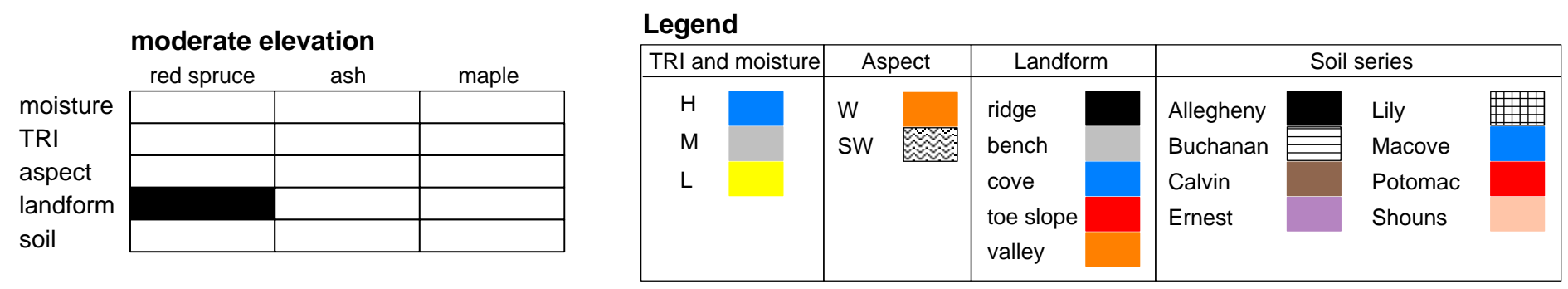

low elevation

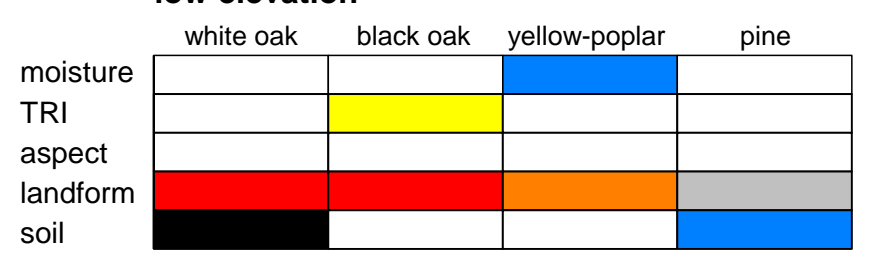

no elevation association

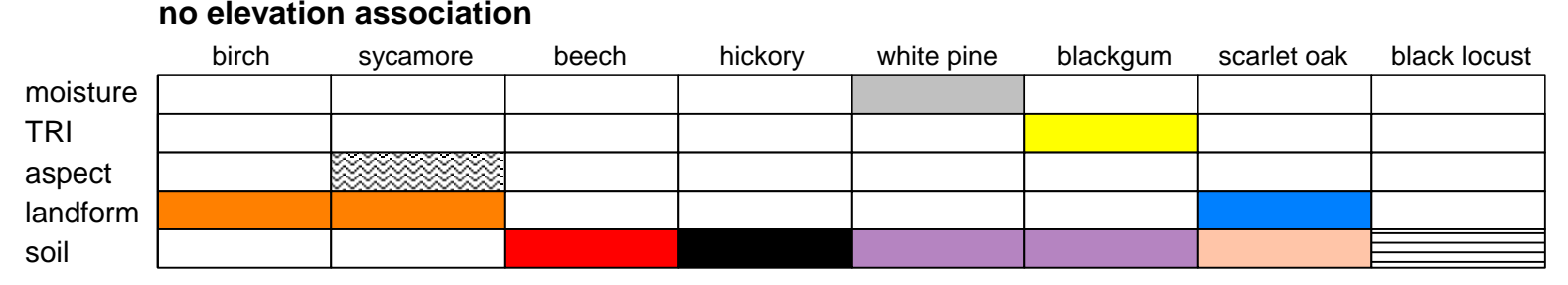


Figure 2.16 - Significant associations $(\alpha=0.05 ; \mathrm{n} \geq 10)$ between tree species and environmental variables (landform, aspect, TRI, moisture index, elevation, and soil series) for the WAM subsection. Blank (white) cells indicate no significant association for that species-site variable combination. The species are grouped first by their association with elevation class.
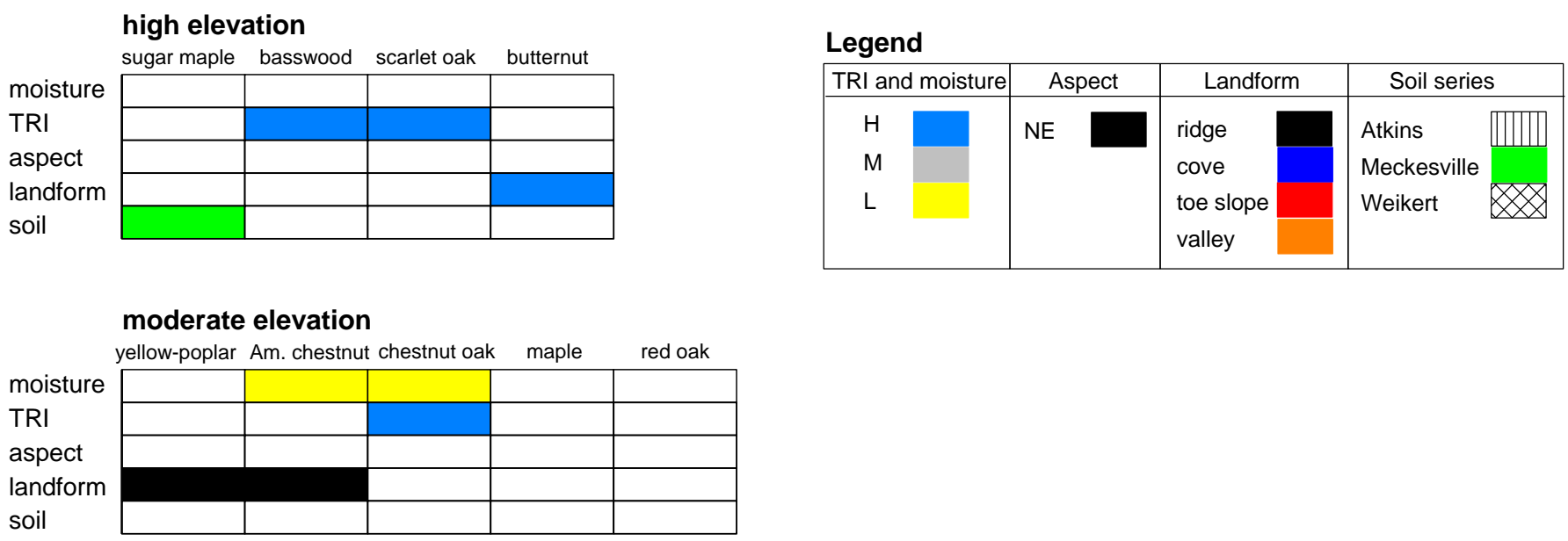

low elevation

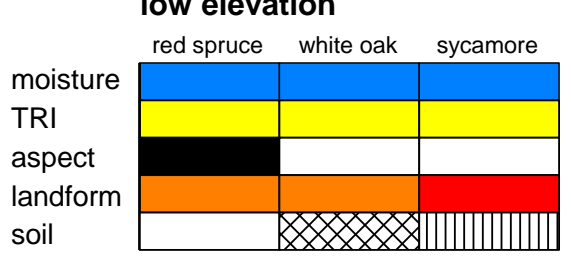

no elevation association

\begin{tabular}{|c|c|c|c|c|c|c|c|c|c|c|c|c|}
\hline & birch & beech & magnolia & ash & $\begin{array}{l}\text { black } \\
\text { cherry }\end{array}$ & $\begin{array}{l}\text { black } \\
\text { walnut }\end{array}$ & black oak & elm & $\begin{array}{l}\text { spruce- } \\
\text { pine }\end{array}$ & $\begin{array}{l}\text { black } \\
\text { locust }\end{array}$ & pine & white pine \\
\hline \multicolumn{13}{|l|}{ moisture } \\
\hline TRI & & & & & & & & & & & & \\
\hline aspect & & & & & & & & & & & & \\
\hline ndform & & & & & & & & & & & & \\
\hline & & & & & & & & & & & & \\
\hline
\end{tabular}


Figure 2.17 - Significant associations $(\alpha=0.05 ; \mathrm{n} \geq 10)$ between tree species and environmental variables (landform, aspect, TRI, moisture index, elevation, and soil series) for the SHAM subsection. Blank (white) cells indicate no significant association for that species-site variable combination. The species are grouped first by their association with elevation class.

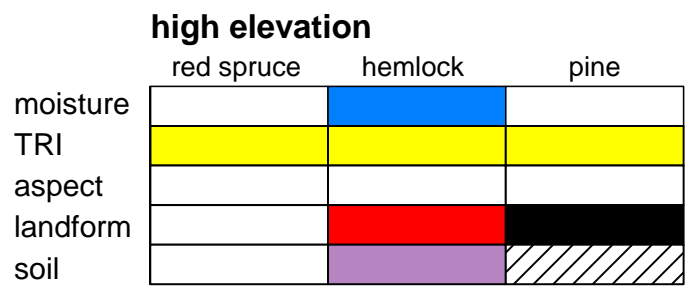

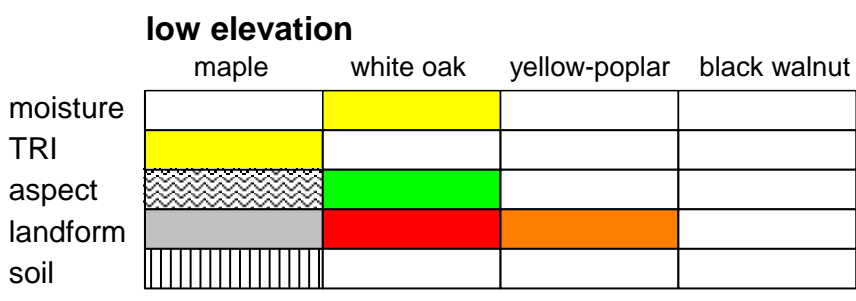

\begin{tabular}{|c|c|c|c|c|}
\hline TRI and moisture & Aspect & Landform & \multicolumn{2}{|c|}{ Soil series } \\
\hline $\mathrm{H}$ & SE & ridge & Atkins & $\pi$ \\
\hline M & SW $\approx \approx$ & bench & Belmont & \\
\hline \multirow[t]{5}{*}{ L } & $\mathrm{N}$ & side slope & Berks & \\
\hline & & toe slope & Ernest & \\
\hline & & valley & Laidig & \\
\hline & & & Mandy & 71 \\
\hline & & & Meckesville & \\
\hline
\end{tabular}

\begin{tabular}{|c|c|c|c|c|c|c|c|c|c|c|}
\hline & beech & spruce-pine & magnolia & red oak & hickory & blackgum & birch & Am. chestnut & chestnut oak & butternut \\
\hline \multicolumn{11}{|l|}{ moisture } \\
\hline \multirow{2}{*}{\multicolumn{11}{|c|}{$\begin{array}{l}\text { TRI } \\
\text { aspect }\end{array}$}} \\
\hline & & & & & & & & & & \\
\hline \multicolumn{11}{|l|}{ landform } \\
\hline soil & & & & & & 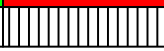 & & & & \\
\hline & sycamore & ash & white pine & sugar maple & basswood & black cherry & black oak & black locust & & \\
\hline \multicolumn{11}{|l|}{ moisture } \\
\hline \multirow{4}{*}{$\begin{array}{l}\text { TRI } \\
\text { aspect } \\
\text { landform } \\
\text { soil }\end{array}$} & & & & & & & & & & \\
\hline & & & & & & & & & & \\
\hline & & & & & & & & & & \\
\hline & & & & & & & & & & \\
\hline
\end{tabular}


Figure 2.18 - Significant associations $(\alpha=0.05 ; \mathrm{n} \geq 10)$ between tree species and environmental variables (landform, aspect, TRI, moisture index, elevation, and soil series) for the WAMV subsection. Blank (white) cells indicate no significant association for that species-site variable combination. The species are grouped first by their association with elevation class.

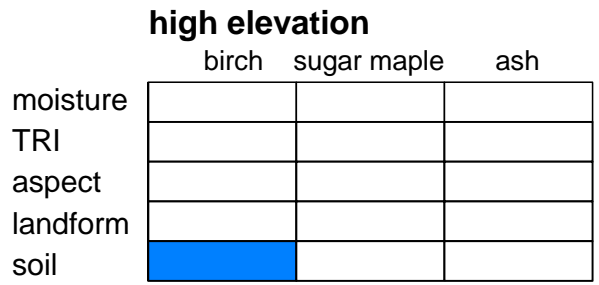

low elevation

yellow-poplar

moisture

TRI

aspect

landform

soil

\section{no elevation association}

\begin{tabular}{|c|c|c|c|c|c|c|c|c|c|c|c|c|}
\hline & beech & blackgum & red oak & basswood & $\begin{array}{l}\text { black } \\
\text { walnut }\end{array}$ & white oak & black oak & $\begin{array}{l}\text { black } \\
\text { locust }\end{array}$ & $\begin{array}{c}\text { Am. } \\
\text { chestnut }\end{array}$ & hickory & $\begin{array}{l}\text { black } \\
\text { cherry }\end{array}$ & $\begin{array}{l}\text { scarlet } \\
\text { oak }\end{array}$ \\
\hline moisture & & & & & & & & & & & & \\
\hline & & & & & & & & & & & & \\
\hline aspect & & & & & & & & & & & & \\
\hline landform & & & & & & & & & & & & \\
\hline & & & & & & & & & & & & \\
\hline
\end{tabular}

Legend
\begin{tabular}{|c|l|l|l|}
\hline TRI and moisture & \multicolumn{1}{|c|}{ Aspect } & \multicolumn{1}{|c|}{ Landform } & Soil series \\
\hline H & NE & ridge & Allegheny \\
M & E & toe slope & Calvin \\
L & NW & & Dekalb \\
& SE & & Macove \\
& N & & \\
\hline
\end{tabular}

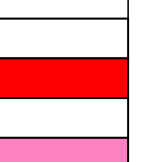


Figure 2.19 - Indicator kriging results for sugar maple witness trees. Interpolations were made on presence/absence of the selected species. Results are given in terms of probability of occurrence.

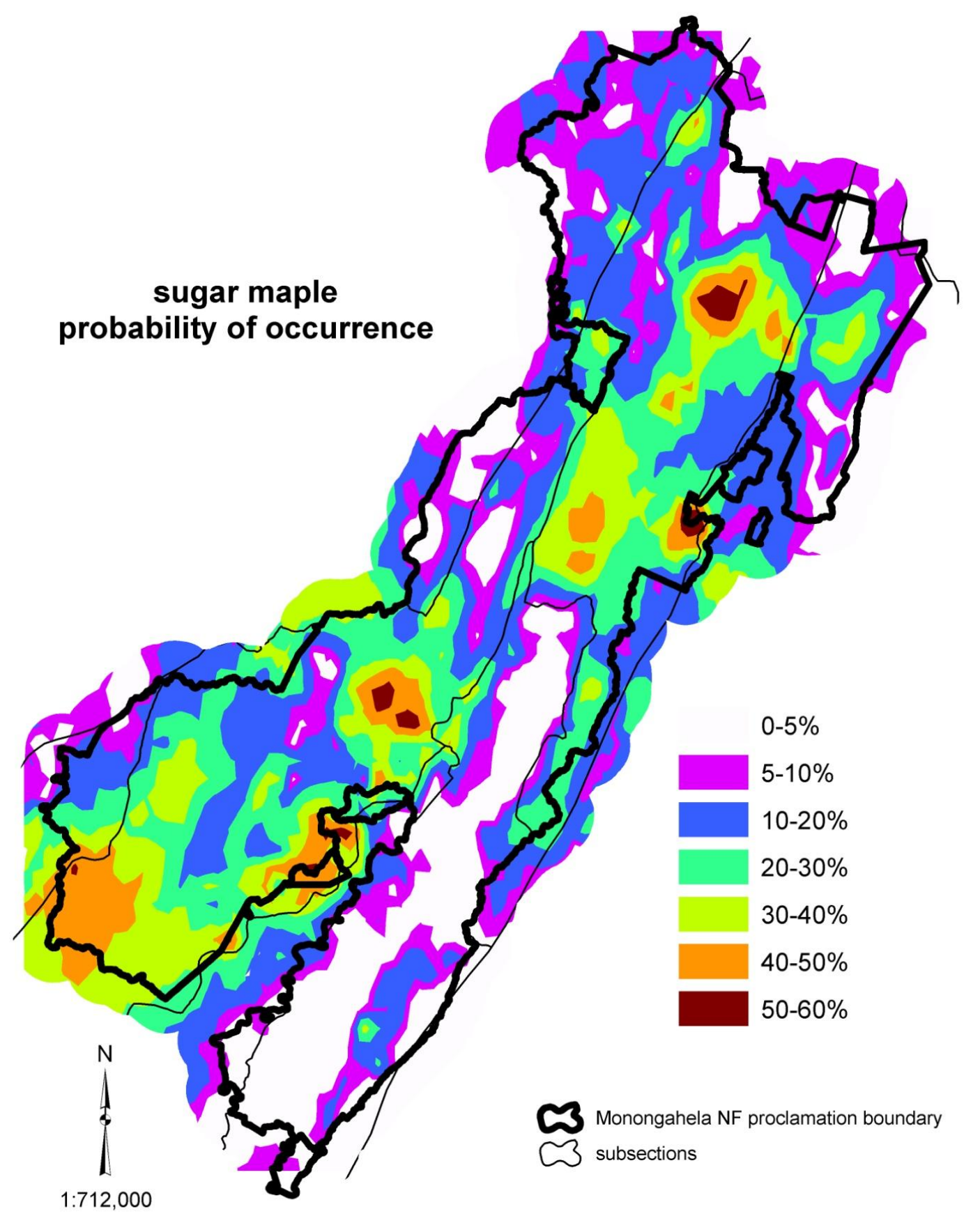


Figure 2.20 - Indicator kriging results for sugar maple or basswood witness trees. Interpolations were made on presence/absence of the selected species. Results are given in terms of probability of occurrence.

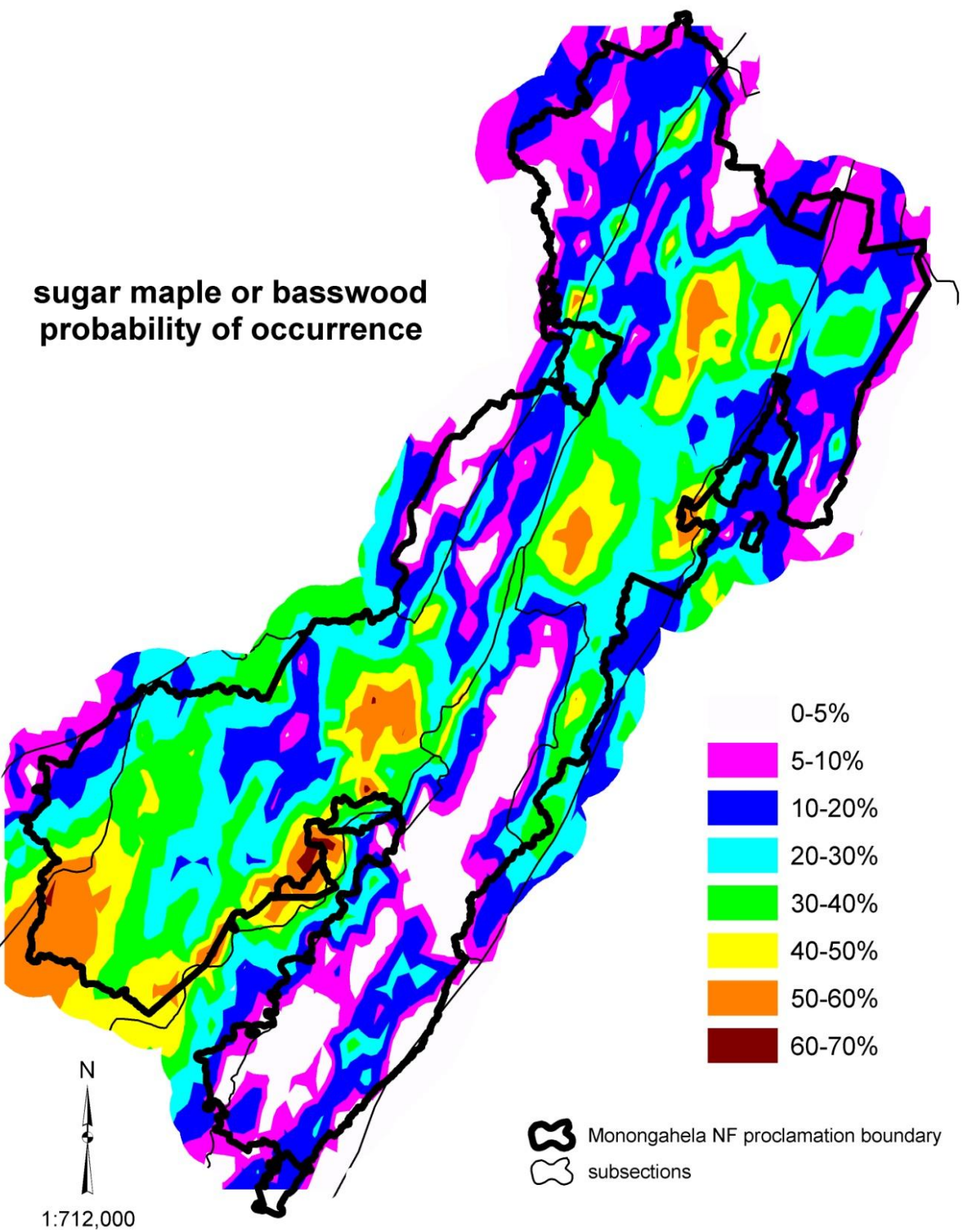


Figure 2.21 - Indicator kriging results for sugar maple or American beech witness trees.

Interpolations were made on presence/absence of the selected species. Results are given in terms of probability of occurrence.

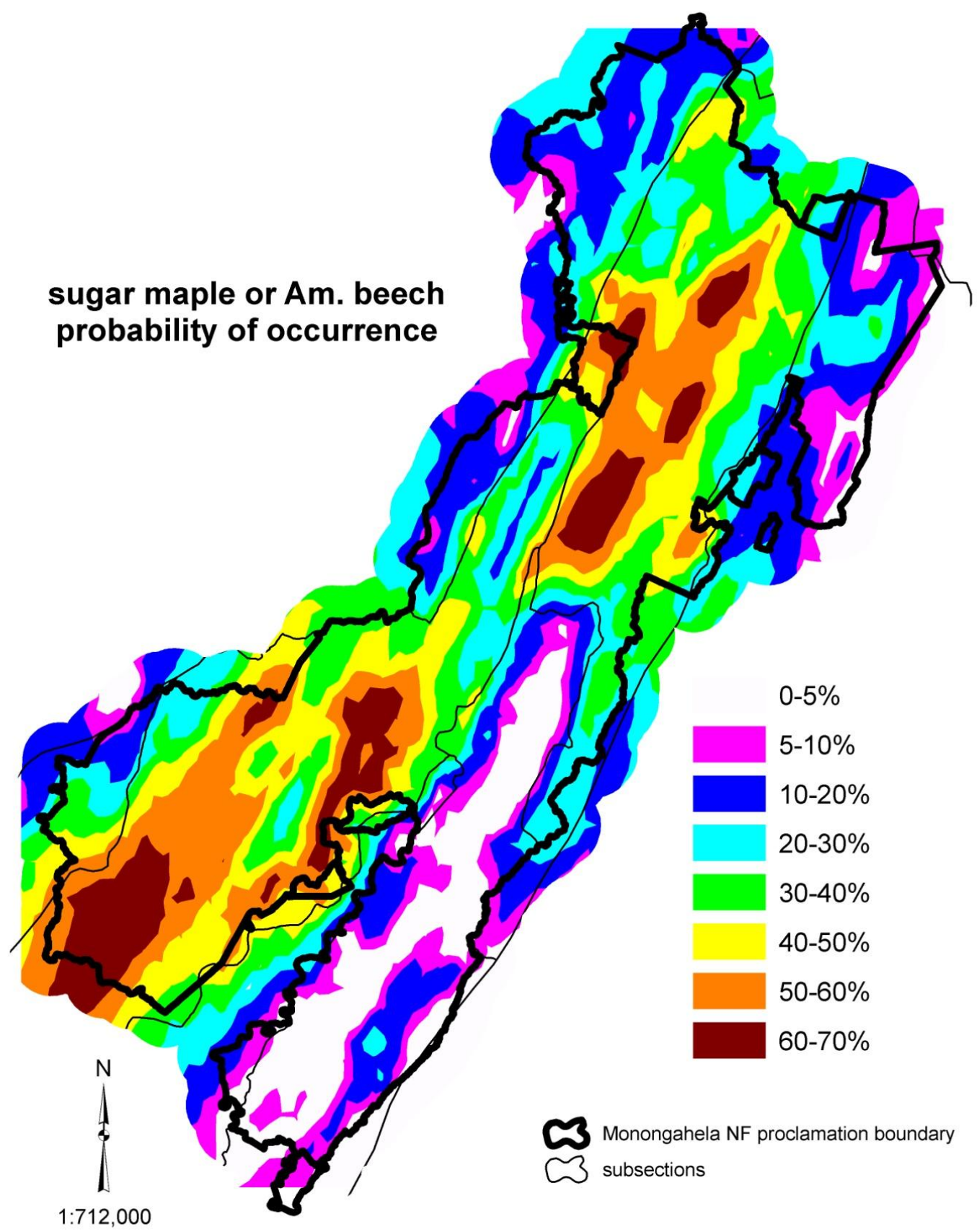


Figure 2.22 - Indicator kriging results for red spruce witness trees. Interpolations were made on presence/absence of the selected species. Results are given in terms of probability of occurrence.

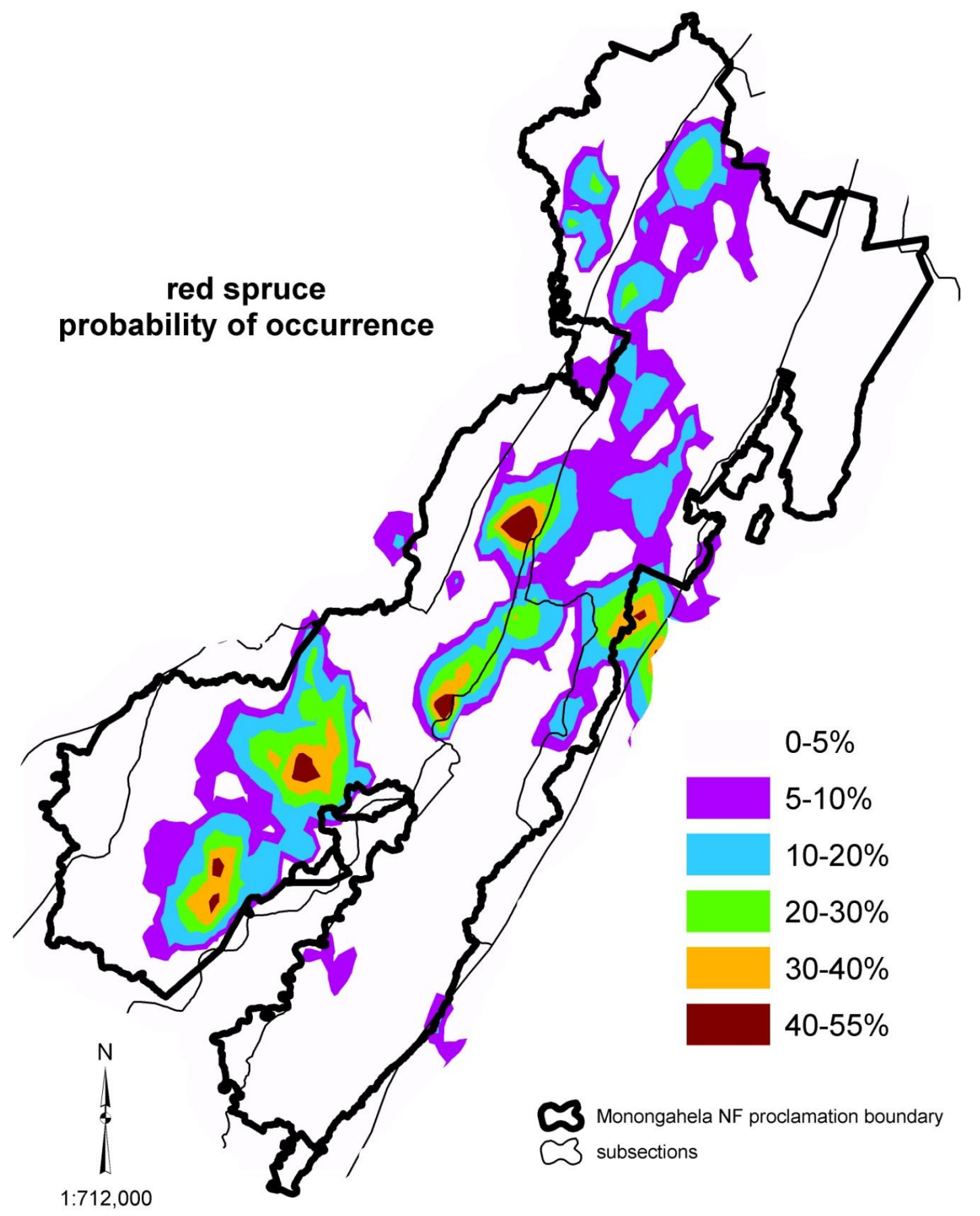


Figure 2.23 - Indicator kriging results for red spruce or birch witness trees. Interpolations were made on presence/absence of the selected species. Results are given in terms of probability of occurrence.

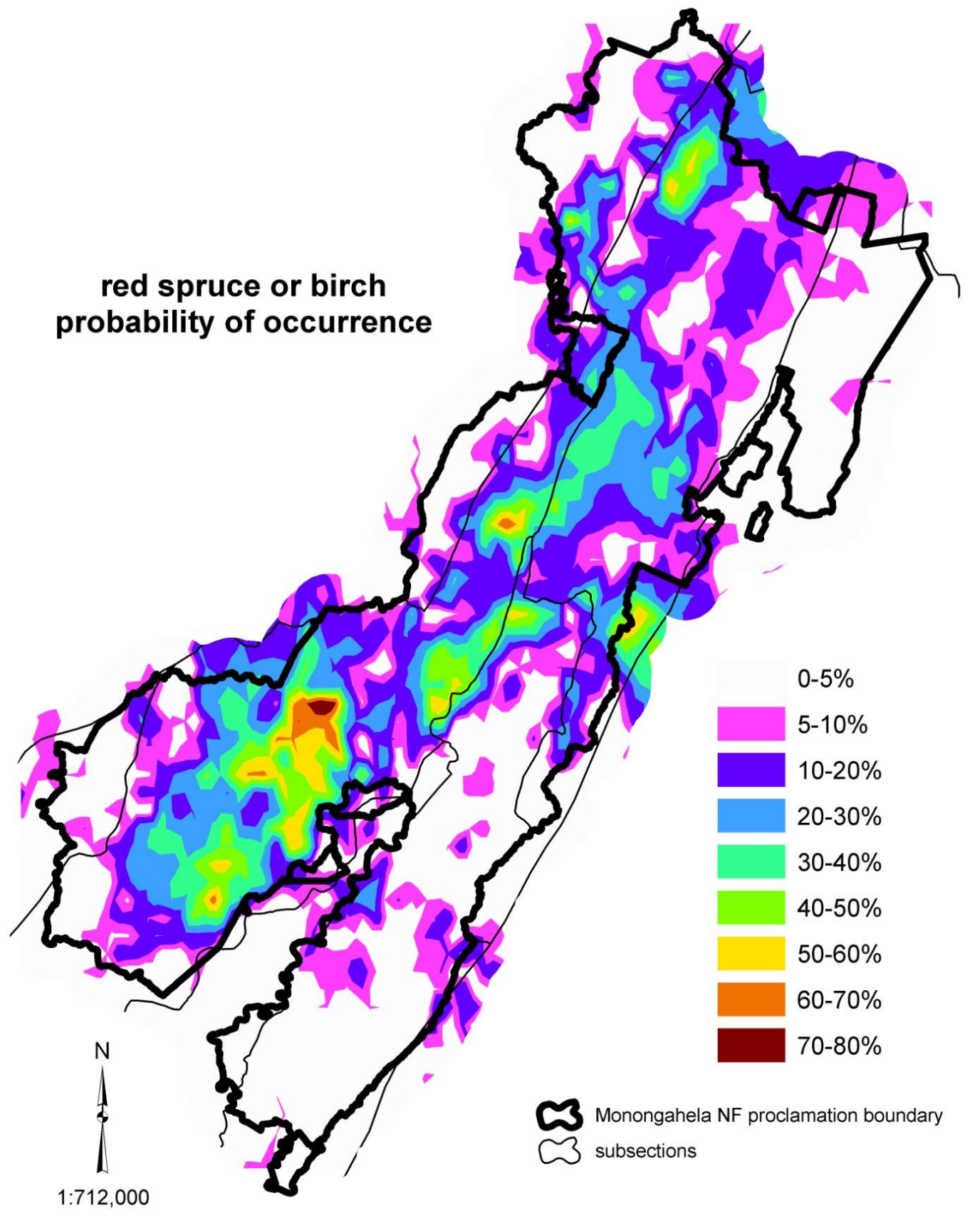


Figure 2.24 - Indicator kriging results for white oak witness trees. Interpolations were made on presence/absence of the selected species. Results are given in terms of probability of occurrence.

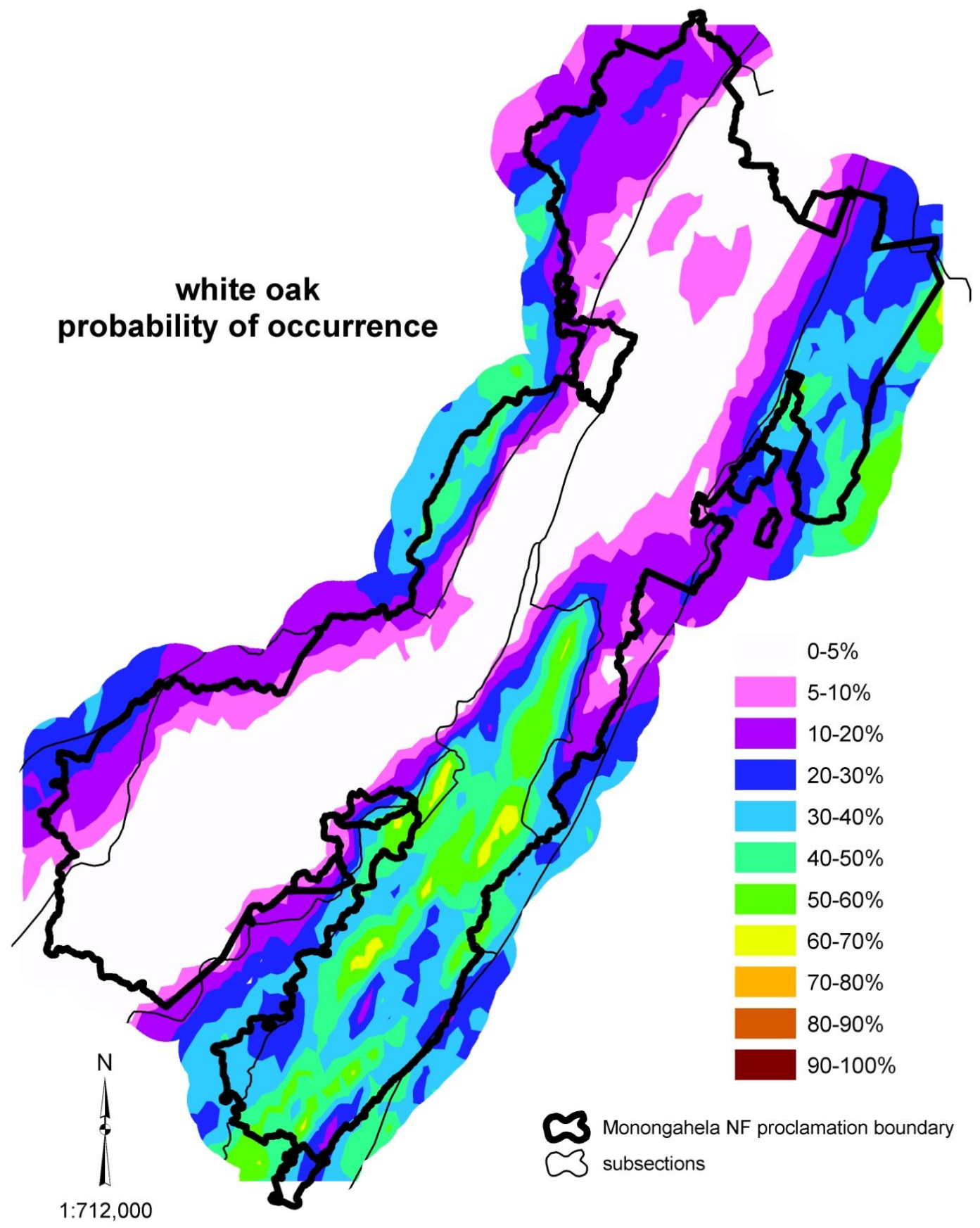


Figure 2.25 - Indicator kriging results for white oak or white pine witness trees. Interpolations were made on presence/absence of the selected species. Results are given in terms of probability of occurrence.

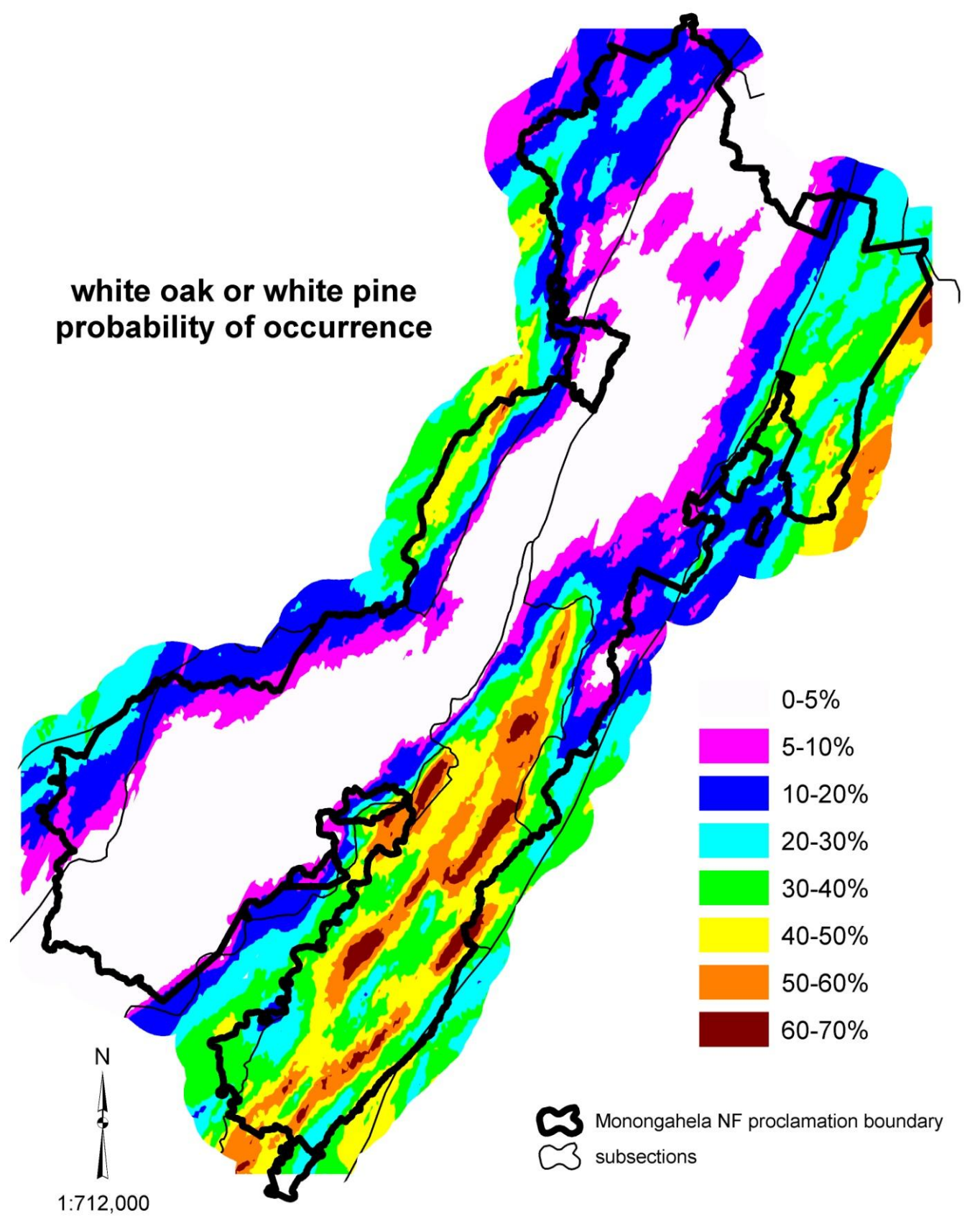


Figure 2.26 - Indicator kriging results for American chestnut witness trees. Interpolations were made on presence/absence of the selected species. Results are given in terms of probability of occurrence.

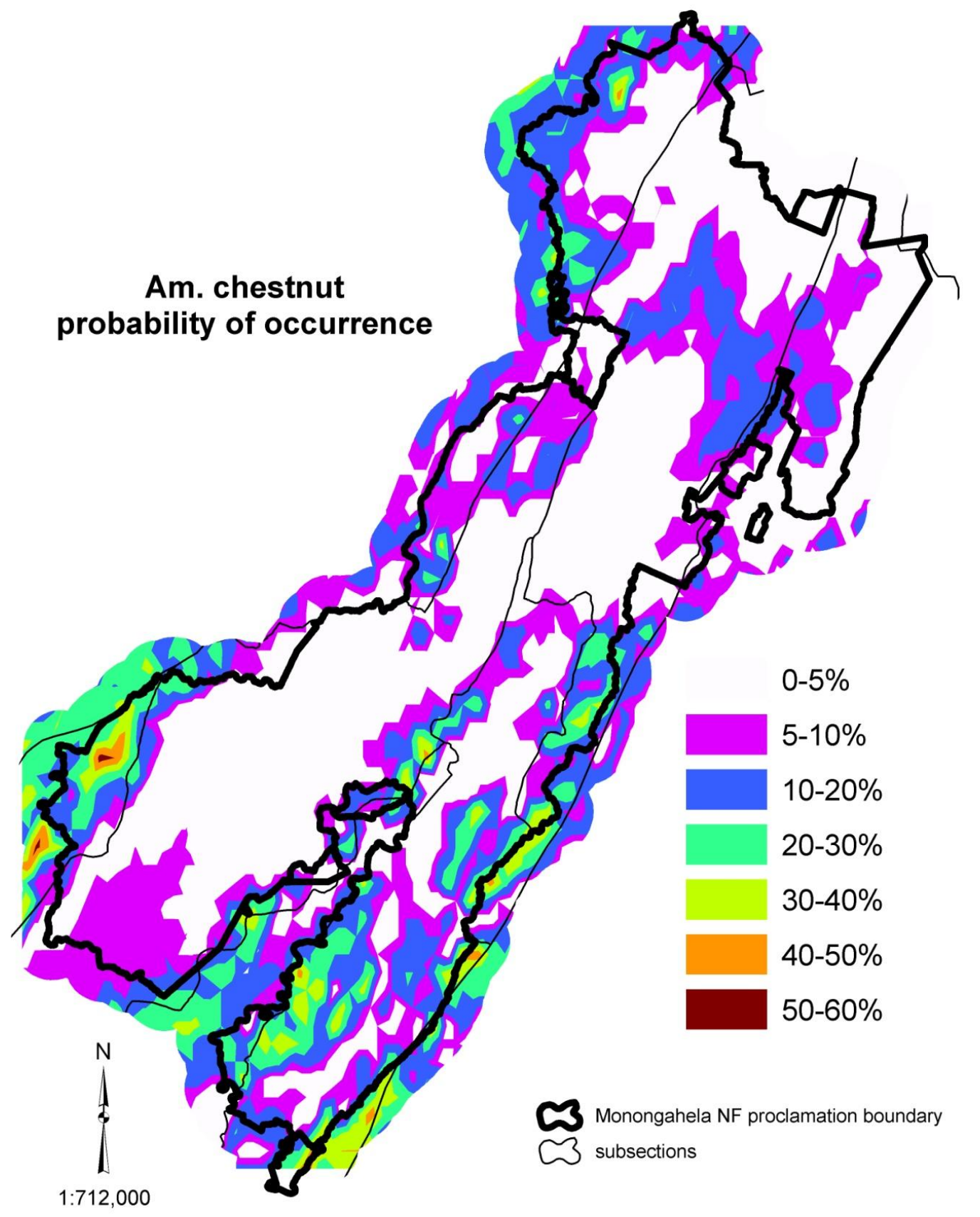


Figure 2.27 - Indicator kriging results for American chestnut or chestnut oak witness trees. Interpolations were made on presence/absence of the selected species. Results are given in terms of probability of occurrence.

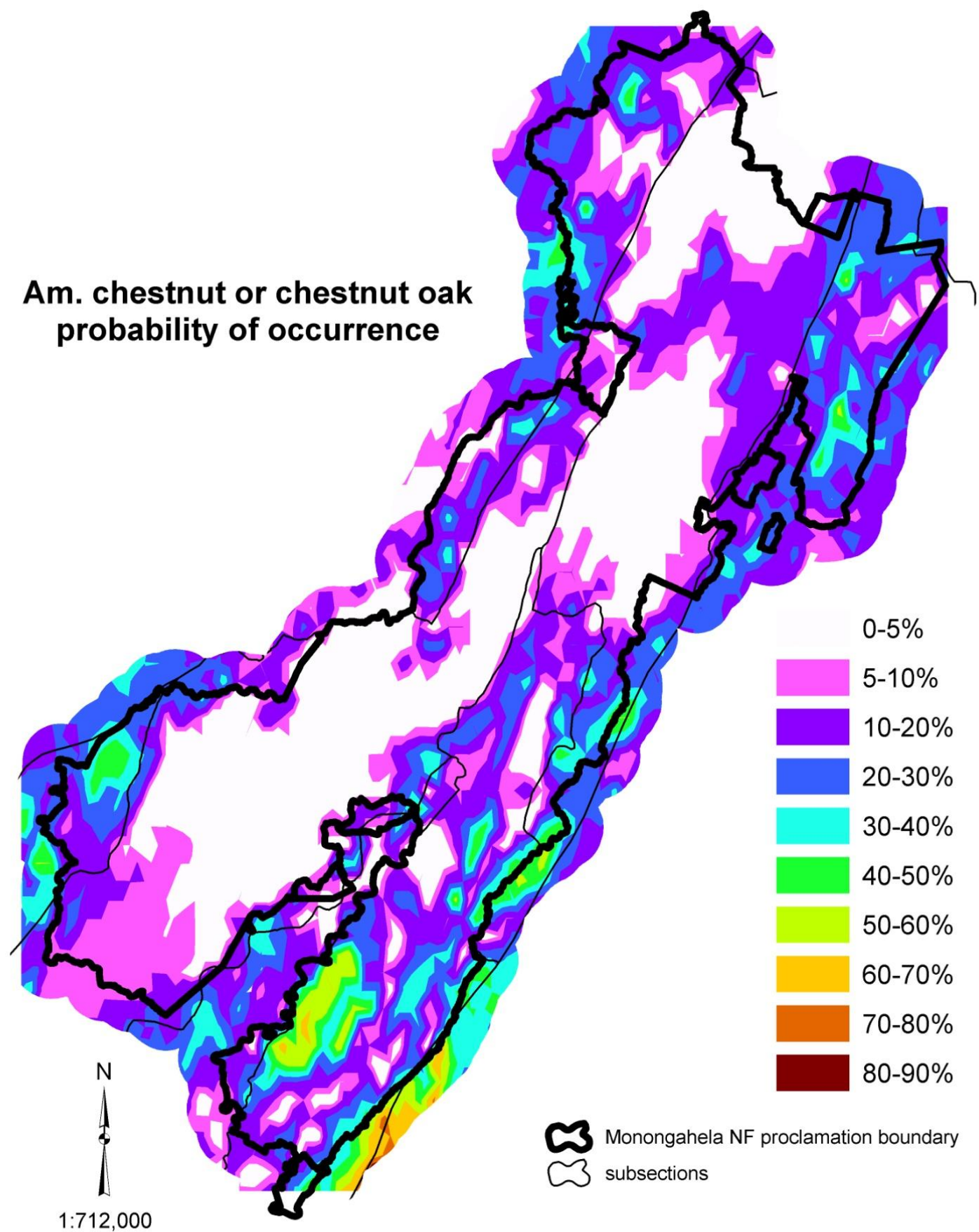


Figure 2.28 - Indicator kriging results for red, scarlet, black, or chestnut oak witness trees. Interpolations were made on presence/absence of the selected species. Results are given in terms of probability of occurrence.

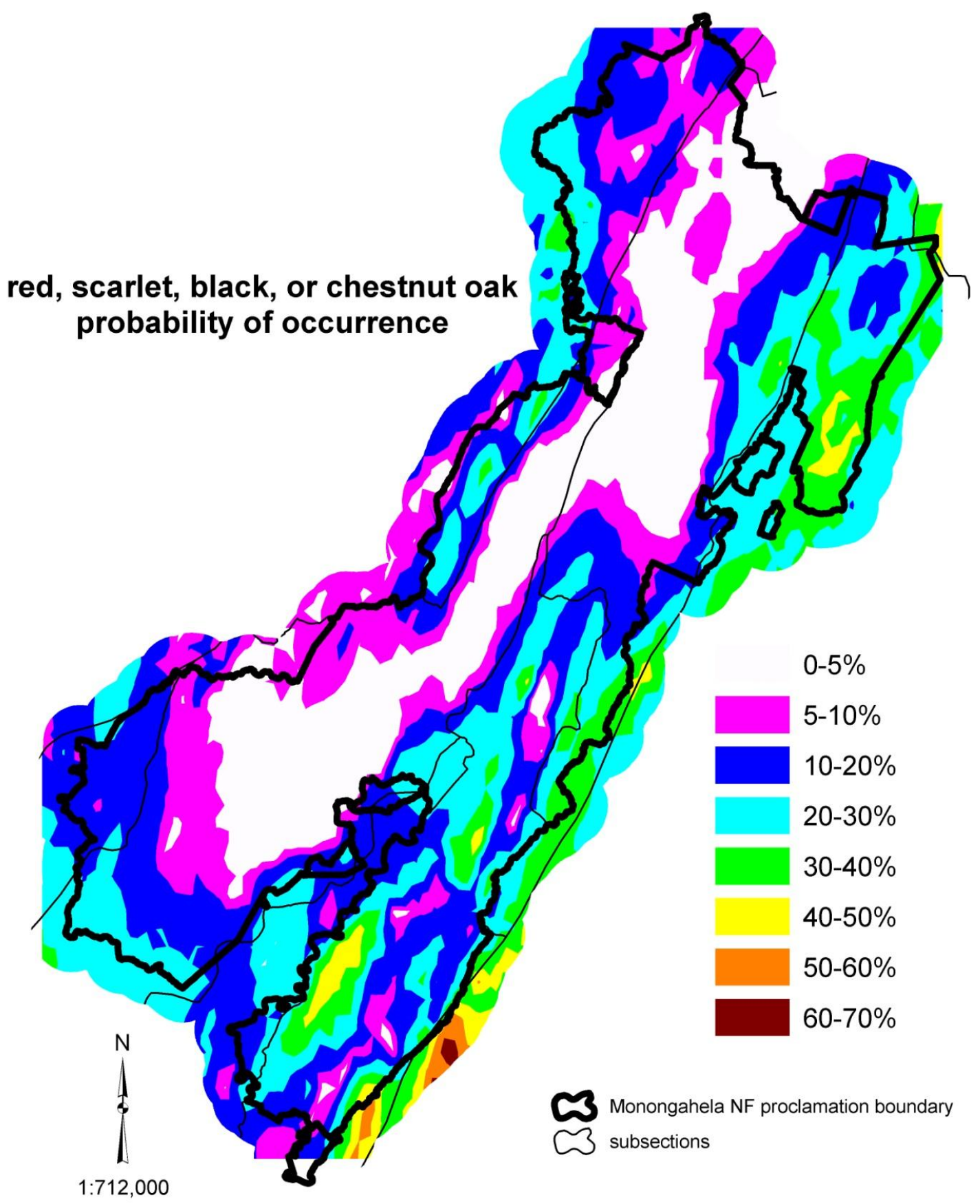


Chapter 3. Influence of Fire, Browse, and Gaps on Oak and Competitors in the Appalachian Mountains

\begin{abstract}
Three disturbance factors thought to influence the development of seedling and sapling layers of oak-dominated hardwood forests were applied alone and in combination on experimental plots in a second-growth forest in eastern West Virginia. Deer browse was controlled through the construction of fences, canopy gaps were created by girdling selected trees, and a ground fire of low to moderate intensity was used. In all, eight treatment combinations were applied: Fire, Fence, Gap, Control, Fire+Fence, Fire+Gap, Fence+Gap, and Fire+Gap+Fence.

Oak seedlings were not affected by any factor other than time; oak saplings were negatively affected by fire and positively affected by fences. Red and striped maple seedlings and saplings were reduced by fire treatments however sugar maple seedlings and saplings were not. Black birch seedlings increased as fire stimulated germination of the seed bank. Creating gaps alone did not increase the seedling relative abundance or importance value of any of the species assessed here, although gaps when combined with other factors, did increase black birch and yellow-poplar seedling abundance and sapling importance values.
\end{abstract}

\title{
Introduction
}

Deciduous forests in the eastern United States are changing in species composition (Fei and Steiner 2007); most notable is the failure of oak (Quercus spp.) species to regenerate on more mesic sites leading to replacement either by the build-up of shade tolerant species, mainly maples (Acer spp.), or by species such as black birch (Betula lenta) and yellow-poplar (Lirodendron tulipifera) that take advantage of increases in light after disturbances such as timber harvest (Lorimer 1984, McGee 1986, McCarthy and others 1987, Crow 1988, Loftis 1990, Nowacki and others 1990, Brashears and others 2004, Nowacki and Abrams 2008). Current forests exist under altered conditions from those the pre-European settlement forests developed under, with higher deer densities in many places (Long and others 2007) and changed fire regimes (Nowacki and Abrams 2008). Traditional successional theories may not apply under these new circumstances. Nonetheless, management that emulates natural disturbances needs to be guided by knowledge of a forests' response to those disturbances. Three key disturbance processes are addressed in this study including canopy gaps, understory fire, and deer herbivory. Understanding the responses of tree species to these disturbances, alone or in combination, is needed for design of appropriate silvicultural and restoration practices. Canopy gaps, understory fire, and herbivory by deer (Odocoileus virginianus) have likely impacted the 
successional trends in eastern hardwood forests and changes in intensity and timing of these disturbance events are impacting successional pathways and current management.

In most eastern deciduous forests, large, stand initiating disturbances such as crown fires and tornadoes can occur, however, the development of most eastern deciduous forests is primarily impacted by the death of one or more canopy trees, creating gaps, and the subsequent changes in site resources and competition for those resources. Classic examples of gap-phase forests are generally those dominated by long-lived shade-tolerant tree species like sugar maple (A. saccharum), American beech (Fagus grandifolia), and eastern hemlock (Tsuga canadensis) (Barden 1980, Runkle 1981, Runkle 1982, Barden 1983, Busing 2005). There are many causes of canopy gaps (drought, wind, insects and disease) leading to differences in the type of gap formed (blowdown, standing dead, basal shear) that also influence site conditions in gaps.

For species that replace themselves in gaps, vegetative reproduction, limited dispersal, and specific site requirements appear more important to gaining canopy status than direct site modification by canopy trees (Runkle 1981). Oak species do have some characteristics important for self-replacement in gaps with the ability to sprout and limited dispersal of acorns. However, in some forests where oaks dominate the overstory, yellow-poplar has the greatest probability of capturing large gaps and maples are likely to dominate smaller and shorter-lived gaps (Hart and others 2010). In beech-maple forests, yellow-poplar had its greatest importance in large gaps (Runkle 1984). Oaks are intermediate in shade tolerance and as such generally require larger canopy gaps to regenerate and/or attain overstory status. Silvicultural guidelines for the oak-hickory (Carya spp.) forest type suggest openings of at least 0.2 ha, however, openings as small as 0.04 to 0.1 ha should perpetuate existing oak advanced regeneration or stump sprouts (Sander and others 1983).

Oak forests have dominated the larger region of the study area for thousands of years (Watts 1979, Davis 1981), yet, studies of existing old-growth and second-growth oak-dominated forests show that replacement of oak overstories with shade-tolerant species such as sugar maple and red maple (A. rubrum) is occurring (McGee 1986, Abrams and Downs 1990, Nowacki and Abrams 1992, Hart and Grissino-Mayer 2009). While oak seedlings may still be found in the understory and in gap openings, oaks no longer appear to have the ability to persist in the understory as they had in the past (as much as 54 years on average for northern red oak [ $Q$. rubra] (Rentch and others 2003). Understory and midstory light levels have been shown as key 
to the persistence of oaks in an understory (Crow 1988, Lorimer and others 1994, Rentch and others 2003).

Understory fire has been suggested as a mechanism by which midstory light levels are changed to favor oak competitiveness (Lorimer 1989). Oak is a poor competitor, which seems counter to its current dominance in most eastern forests (Lorimer 1989). Oaks are not well adapted to low light conditions, although seed will germinate in shade, and late successional oak forests are generally limited to the more xeric sites (Abrams 1992). However, oaks do posses many ecophysiological factors that indicate adaptation to fire, such as thick bark on mature trees, ability to form seedling-sprouts, ability to stump sprout, deep root system, ability to compartmentalize stem injury, and rot resistance (Abrams 1992).

Many prescribed fire studies show advantages are conferred on oak species with fire through reduction of interfering vegetation and/or increased root:shoot ratios of oaks (Arthur and others 1998; Clatterbuck 1998; Barnes and Van Lear 1998; Elliott and others 1999; Signell and others 2005; Blankenship and Arthur 2006; Iverson and others 2008). Often, more than one fire and a reduction in overstory density shows greatest benefit to oaks (Loftis 1990; Keyser and others 1996; Brose and Van Lear 1998; Brose and others 1999a; Brose and others 1999b; Brose and Van Lear 1999). Oak sapling densities were found to be highest in areas with four fires in West Virginia, and while neither non-oak nor oak seedling densities differed by fire occurrence, aggregate oak seedling heights were highest in areas burned four times over 36 years between 1972 and 2008 (Wood 2010). Other studies have noted little to no positive impact of fire on oak species (Collins and Carson 2003), finding that vigorous oak sprouts were not produced by topkilled oak saplings and no seedling-sprouts were reported. In a study comparing sites burned one time to sites burned three times and unburned sites, both fire regimes decreased survival of red maple seedlings but neither reduced the growth of surviving red maple (Alexander and others 2008). While fires did temporarily increase light levels and decrease red maple survival, survival and growth of oaks seedlings was similar or lower than unburned controls (Alexander and others 2008). In a similar study, prescribed fires were seen as acting to select for more competitive red maple seedlings, especially without additional treatment of the midstory (Green and others 2010).

Fire does top-kill oak seedlings and sprouts, so reduction in their numbers is expected immediately after a fire. Repeated burning and resprouting of oaks and their competitors is 
expected to create conditions where competitors such as red maple and yellow-poplar deplete their energy reserves and seed banks faster than oaks due to physiological differences (Lorimer 1985). These insights on fire and oak forest development have led to the application of prescribed fire on many public and some private lands where oaks dominate the overstory.

White-tailed deer is the main browser currently impacting eastern hardwood forests. Before European settlement, deer populations were mainly affected by Native American hunting and predation by the now extirpated eastern timber wolf (Canis lupus) and eastern cougar (Felis concolor). Low numbers of deer in West Virginia were noted as early as 1841 and populations were affected by market hunting and extensive timber harvest in the 1900s (Smith 1993). Remote and mountainous areas of the state supported scattered deer populations (Smith 1993). In these mountain counties, deer were first reintroduced starting in 1933, and the regenerating forests provided ample browse for surviving native deer (Smith 1993). Deer populations declined as the forests matured and hunting of antlerless deer was allowed (Smith 1993). Populations rose again in the $20^{\text {th }}$ century, especially as compared to estimates of $18^{\text {th }}$ and $19^{\text {th }}$ century deer populations (Horsley and others 2003). Today, negative impacts from high deer populations are noted on species composition (Tilghman 1989, Horsley and others 2003, Campbell and others 2006) and on the height of regeneration (Tilghman 1989). In an enclosure study (Horsley and others 2003), high deer densities were associated with decreases in seedling heights and tree seedling diversity, and increases in the abundance of browse-resistant, nonpalatable species such as ferns and sedges. Negative impacts were first observed at deer densities of greater than $8 \mathrm{deer} / \mathrm{km}^{2}$ (Horsley and others 2003). Heavy browsing of sassafras (Sassafras albidum), American basswood (Tilia americana), yellow birch (B. alleghaniensis), and chestnut oak ( $Q$. prinus) in clearcuts with a deer density of 14 deer $/ \mathrm{km}^{2}$ was expected to result in a reduction of these species and an increase in American beech, yellow-poplar and red maple which experienced less browse pressure (Campbell and others 2006).

Other disturbances have shaped the oak-dominated forest of West Virginia. Oaks may have gained their overstory dominance because of rapid land use changes, including European use of fire, and forest clearing and grazing between 1880 and 1930 (McEwan and others 2007). The loss of the American chestnut (Castanea dentata) was found to have increased the importance of chestnut oak, northern red oak, and red maple in oak-chestnut forests (Woods and Shanks 1959). As with other canopy disturbances, replacement of American chestnut occurred 
either by the closure of the canopy by adjacent trees, release of advanced regeneration, or establishment of new seedlings after death of the American chestnut (Woods and Shanks 1959). An analysis of witness trees on the Monongahela National Forest (MNF) has shown that American chestnut and chestnut oak were often associated with the same set of environmental variables suggesting that existing chestnut oak may have benefitted from the loss of American chestnut (Thomas-Van Gundy, this document). The loss of American chestnut as a source of mast may have impacted oak regeneration negatively through increased acorn predation. The loss of the passenger pigeon (Ectopistes migratorius) may have also influenced oak regeneration by removing this disturbance factor that might have favored oaks (Ellsworth and McComb 2003). Conversely, reductions in deer and turkey (Meleagris gallopavo) populations (and thus acorn predation) after the turn of the $20^{\text {th }}$ century logging may have given an advantage to regenerating oaks (McEwan and others 2010). Climate cycles may also have a played a role in the relative abundances of oaks and maples in eastern hardwood forests. Eastern North America has experienced cycles of drought over about 400 years and that the last 100 years has been a time of increased moisture availability (McEwan and others 2010). In general, oak species are more tolerant of drought than maples or black birch, with many of the physiological adaptations ascribed to fire-tolerance also serving to allow species to tolerate drought, so increased moisture availability over the past 100 years may have reduced and increased the competitive advantage of oaks and maples, respectively.

Disturbance processes associated with fire, canopy gaps, and browse were incorporated into a long-term study on the Fernow Experimental Forest (FEF) and the MNF. The study consists of four main plots; two on the FEF and two on the Cheat District of the MNF, and is referred to as the Fire-Fence-Gap Study. In this analysis, the responses of seedling and sapling maples (sugar, red, and striped maple [A. pensylvanicum]), yellow-poplar, black birch, and oaks (northern red, chestnut, white $[Q . a l b a]$, and black oak $[Q$. velutina $]$ ) to fire, browse, and gaps are examined. The non-oak species were chosen for analysis because they are the main competitors of oaks in the region. Shade-tolerant maples can dominate the sapling layer of a stand creating dense shade hindering the movement of oaks from seedlings to saplings. Yellowpoplar (shade intolerant) and black birch (intermediate in shade tolerance) become competitors with oak after a disturbance increases light to the forest floor or stimulates seed stored in the forest floor. 
Three hypotheses based on these disturbance processes are tested by this study. The first hypothesis is that periodic fires will promote the regeneration and growth of fire tolerant species, including oaks, while reducing fire-intolerant species. Repeated prescribed fires are predicted to increase the relative abundance of fire tolerant tree species and reduce the relative abundance of fire intolerant species. The second hypothesis tested is that browsing by deer prevents palatable species from establishment or attaining sapling size. Excluding deer (through fencing) is predicted to increase growth and survivorship of all species, but differences will be most notable in the most palatable species. For the third hypothesis it is predicted that oaks, and other species of intermediate shade tolerance, will have higher recruitment, growth, and survivorship in areas with large (multi-tree) canopy gaps as compared to those areas without gaps.

\section{Methods}

Study Area and Experimental Design

The study area is located near Parsons, West Virginia, in the Western Allegheny Mountains ecological sub-section (Cleland and others 2007), dominated by a mixed mesophytic hardwood forest (Figure 3.1). The area receives an annual mean of 1,430 $\mathrm{mm}$ of precipitation distributed evenly throughout the year (Pan and others 1997). The FEF study plots (7942'13'; $39^{\circ} 2^{\prime} 20^{\prime \prime}$ and $\left.79^{\circ} 42^{\prime} 1^{\prime \prime} ; 39^{\circ} 1^{\prime} 50^{\prime \prime}\right)$ range in elevation from 670 to $790 \mathrm{~m}$ with one site facing southeast and the other west. Study plots on the MNF (79'43'37'W; 396'4'N and 7943'3'W; $39^{\circ} 6$ '22”N) range in elevation from approximately $670 \mathrm{~m}$ to $760 \mathrm{~m}$ elevation and have generally north to west aspects. The study plots are in upland locations and include side slopes and ridge landforms. Study areas were 10 to 40 ha in size. These four areas are termed main plots with treatments applied at this level and sub plot level.

The study areas were generally unmanaged or minimally managed second-growth stands (between 60 to 90 years old) with overstories dominated by northern red oak and white oak (Table 3.1). Other canopy species included: yellow-poplar, sugar maple, red maple, American beech, black cherry (Prunus serotina), and black birch when the treatments were applied. Before treatment, maples dominated the sapling and seedling components of these stands (Table 3.1). No research or timber harvest activities had taken place in the study sites within the last 27 years before the start of this study in 1999. One MNF plot was thinned in 1972, the other in 1956. 
Fire, gaps, and browse effects were controlled for in a split-plot factorial design initiated in 1998 (Collins and Carson 2003). Within each of the four main plots, sixteen 20 by $20 \mathrm{~m}$ (400 $\mathrm{m}^{2}$ ) plots were established with plots located at least $20 \mathrm{~m}$ from each other, stand edges, and fire breaks. Plots were located to avoid existing canopy gaps and large rock outcrops. The main plots were divided in half and prescribed fire randomly assigned to half of the plots for the burned treatment. Within each half, two plots were randomly assigned to a fence, gap, fence plus gap, or control treatment resulting in a total of 64 plots with treatments of Fire, Fence, Gap, Fence+Gap, Fire+Fence, Fire+Gap, Fire+Fence+Gap, or Control (Figure 3.2). The naming convention for this analysis is that the eight individual treatments are capitalized; factors given in lowercase indicate that the response variable has been averaged across the two levels of the other two factors.

Plots were established in 1998 and initial data collected in 1999 under methods similar to Collins and Carson (2003). The fence and gap treatments were applied in 2000. Fences were two meters tall and constructed of 14-gauge woven wire fence reinforced with rebar and metal posts. Gaps were created by girdling trees greater than $10 \mathrm{~cm}$ diameter breast height (DBH) and injecting them with herbicide (Accord $®$ ). The resulting gaps were about $250 \mathrm{~m}^{2}$ by summer of 2001. Prescribed fire was applied in the spring of 2001; all sites received one burn. Strip head fires were used to control rate of spread and fire intensity and no overstory mortality due to fire occurred. Fire temperatures were greatest at ground surface at $245^{\circ} \mathrm{C}\left( \pm 15.4^{\circ} \mathrm{C}\right)$ and coolest at 1 $\mathrm{m}$ from ground surface $\left(91.9^{\circ} \pm 1.7^{\circ} \mathrm{C}\right)$ as measured by fire-sensitive paints on aluminum tags (Royo and others 2010). Experimental fires simulated historic surface fires by consuming mainly leaf litter and small woody debris with most sub plots experiencing nearly complete burns (Royo and others 2010).

\section{Data Collection}

Before treatment (1999), all individual tree species stems greater than $140 \mathrm{~cm}$ tall were identified, mapped, tagged, and DBH measured in each plot. In the center of each plot, a $100 \mathrm{~m}^{2}$ sub-plot was established where all seedlings greater than $20 \mathrm{~cm}$ in height were tagged, mapped, and measured for height and basal diameter. Pre-treatment data for four sub-plots are missing for one MNF main plot and had been assigned to Fence (two sub-plots), Gap, and Fence+Gap treatments. One sub-plot assigned to the Control treatment is missing 1999 data in a FEF plot. 
Sapling data are missing for 1999 in one sub-plot assigned to the Fire+Gap treatment on the MNF.

By 2007/2008, regeneration responses in many of the treatment sub-plots did not allow for continued tagging and mapping of individual seedlings and saplings, nor census of seedlings over the entire plot. Saplings before 2007/2008 were defined as greater than $140 \mathrm{~cm}$ tall with DBH of $1.0-10.0 \mathrm{~cm}$. Given the response in the gap and fenced plots, this definition and individual stem tracking made data collection inordinately time consuming. Seedling and sapling definitions were changed for the 2007/2008 census to create more functional groupings. In 2007 and 2008, seedlings were defined as those stems less than $2.54 \mathrm{~cm}$ in DBH. Saplings were defined as stems over $140 \mathrm{~cm}$ and between 2.54 and $12.7 \mathrm{~cm} \mathrm{DBH.} \mathrm{Sampling} \mathrm{of} \mathrm{seedlings}$ in $2007 / 2008$ occurred on five randomly placed 0.001 ha circular plots ( $1.78 \mathrm{~m}$ radius) throughout the $400 \mathrm{~m}^{2}$ plot. Saplings and overstory trees were sampled on the entire $400 \mathrm{~m}^{2}$ plots.

In 2007/2008, basal diameters were not recorded for seedlings as there were large numbers of individuals in many treatment plots. Seedlings were tallied by height class in $2007 / 2008$ and no notation of browse or dieback was made on individual seedlings. Seedling height classes used in the latest census were: $0-20 \mathrm{~cm}, 20-30.5 \mathrm{~cm}, 30.5-100 \mathrm{~cm}, 100-140 \mathrm{~cm}$, and greater than $140 \mathrm{~cm}$. Seedlings tallied as height class $1(0-20 \mathrm{~cm})$ were not included in the analysis to remain consistent with the previous seedling height definition. Size class assignments of seedlings and saplings from the 1999 censuses were changed to reflect new definitions for accurate comparisons across years.

\section{Analysis Methods}

For seedlings, relative abundances (percent of total stems/ha) were calculated pre and post treatment (1999 and 2007/2008) using the 2007/2008 definition. For saplings, importance values (IV) were calculated as the average of relative abundance (percent of total stems/ha) and relative density (percent of total basal area/ha in $\mathrm{m}^{2}$ ) for the same time periods as the seedlings and using the new definition.

Analysis of treatment effects and interactions were made using a generalized linear mixed model via PROC GLIMMIX using a pseudo-likelihood estimation technique (SAS 2006). A split-plot factorial repeated-measures design was used. Fire was the whole plot unit and fence 
and gap were the subplot units. The levels of fire (fire/no fire), canopy gap (gap/no gap), browse control (fence/no fence) and their associated interactions were modeled as fixed effects. Time was the repeated measurement in the model and the between-year correlation was evaluated with the compound symmetry covariance structure; other covariance structures were modeled however, the compound symmetry structure consistently resulted in convergence of the model. Denominator degrees of freedom were adjusted using the Kenward-Rogers method and the Tukey-Kramer method was used to adjust for multiple comparisons.

The dependent variables were evaluated using the beta distribution and the log link function. Dependent variables analyzed were relative abundances of striped maple, red maple, sugar maple, black birch, yellow-poplar, and all oak species seedlings and IVs for saplings of the same species. The GLIMMIX model was designed to detect overall differences caused by treatment (between-subject effects) and interactions among treatments and time (within-subject effects). The within-subject effects are the main focus of the results and discussion presented here as the effects of the treatments over time and in their interactions are the primary interest. The within-subject effects are described three ways; treatments as binary (i.e. all fire treatments compared to all non-fire treatments), interactions between two treatment (i.e. fire and no fire treatments compared to gap and no gap treatments averaged across both fence treatments), or as the eight individual treatments.

To test for initial site differences between FEF and MNF, total numbers of seedlings and total numbers of saplings per hectare were compared through PROC GLM (SAS 2006). Both response variables were log transformed before analysis. If statistically significant differences exist between the main sites, subsequent analyses will be made separately by site.

\section{Results}

There were significant differences between the four plots in total seedlings and total saplings per hectare pre-treatment ( $\mathrm{p}=0.0022$, and $\mathrm{p}<0.0001$, respectively) with the two plots on the MNF different from those on the FEF. Although one main plot on the FEF did not differ from the two MNF main plots for total seedlings per hectare, the seedling and sapling data will be assessed as two groups of two main plots. 


\section{General Trends - Seedlings}

Before treatment there were 28 species of trees, shrubs, and vines represented in the seedling layer on the FEF plots and 34 species after treatment. Nine species were added to the tally post-treatment (sumac [Rhus thyphina], Dutchman's pipe [Aristolochia macrophylla], hickory, mountain holly [Ilex montana], yellow-poplar, aspen [Populus spp.], white oak, basswood, and elderberry [Sambucus spp.]) and three species were no longer found: (spicebush [Lindera benzoin], Virginia creeper [Parthenocissus quinquefolia], and choke cherry [P. virginiana]). Before treatment, maples and oaks were the most abundant tree seedlings, comprising nearly $55 \%$ and $25 \%$ of the total, respectively.

The simple means of seedling relative abundances by treatment show that striped maple seedlings dominated Control and Fence plots post-treatment (Table 3.2). While striped maple occurred in plots of all treatment types, it was found in lowest abundance in Fire plots. Red and sugar maples were least abundant in Fire+Gap and Fire plots. Red maple was most abundant in Fence+Gap plots, while sugar maple was most abundant in Fire+Fence plots.

Black birch had its greatest relative abundance in Gap plots and was absent in Control and Fence plots. Average relative abundance of American beech was low across all treatments, but its greatest occurrence was found in Fence+Gap plots; it was absent in the Control, Fire, Fire+Fence, and Fire+Fence+Gap plots. Yellow-poplar seedlings were abundant in Fire+Gap, Fire, and Fire+Fence+Gap, plots, and absent in Control and Fence plots. Very few white oak seedlings were found regardless of treatment. Chestnut oak also occurred at low abundances across treatments, but seedlings were most abundant in Gap plots. Of the oaks, Northern red oak exhibited the greatest relative response to treatments. This species was first and second in abundance, respectively, in the Fire and Fire+Fence+Gap plots.

Before treatment in the MNF plots, there were 30 species in the seedling layer; posttreatment there were 32 with eight species added (devil's walking stick [Aralia spinosa], dogwood [Cornus florida], mountain holly, pin cherry [P. pensylvanica], sumac, black locust [Robinia pseudoacacia], elderberry, and blueberry [Vaccinium spp.]) and six species dropped (Dutchman's pipe, mountain laurel [Kalmia latifolia], hophornbeam [Ostrya virginiana], Virginia creeper, choke cherry, and hemlock). Before treatment, maples and oaks were the most abundant species-groups of tree seedlings, comprising nearly $46 \%$ and $28 \%$ of the total, respectively. 
Post-treatment, maple species, mainly striped maple, dominated the non-fire treatment plots and yellow-poplar dominated most of the fire treatment plots post-treatment (Table 3.3). Black birch was most abundant in the Fire treatment plots, American beech in the Fire+Gap plots (although only 5.7\%), and yellow-poplar had greatest relative abundance in Fire+Gap plots. Striped maple was most abundant in the Fence plots, red maple the Fence+Gap plots, and sugar maple the Fence+Gap plots. Sugar maple was not abundant post treatment in the MNF plots. White oak seedlings post-treatment were scarce in all plots making up just $1 \%$ of the relative abundance in the Fire plots (Table 3.3). Chestnut and northern red oak had their highest relative abundances in the Gap plots.

\section{General Trends - Saplings}

The numbers of species found in the sapling layer in the FEF plots declined overall by one between 1999 and 2007/2008. Five species were added (devil's walking stick, pin cherry, northern red oak, sumac, and hemlock) and six species dropped out (serviceberry [Amelanchier arborea], American chestnut, hickory, hophornbeam, chestnut oak, and basswood) by 2007/2008. Before treatment, maples and black birch dominated this stratum, comprising more than $76 \%$ and $11 \%$ of the size class, respectively; there were very few oak saplings of any species before treatment $(0.8 \mathrm{stems} / \mathrm{ha})$.

Simple means of post-treatment IV by species and treatment show the differing responses of maple species (Table 3.4). Striped maple was not present in Fire and Fire+Fence treatment plots and had its greatest IV in Fire+Gap plots. In comparison, red maple showed its greatest IV in Fire plots and lowest IV in the Fire+Gap, Fire+Fence, and Fire+Fence+Gap plots. Sugar maple dominated the Control, Fire, and Fire+Fence plots, and made up over $20 \%$ of the total IV in all other plots. Yellow-poplar saplings were absent from Control, Fence, Fire, and Fire+Fence plots and had greatest IVs in the Fire+Fence+Gap plots. Northern red oak was the only species of oak found in the sapling layer in the FEF plots and only occurred in the Control and Fence+Gap plots. Eastern hemlock was only found in the Fence treatment plots (Table 3.4).

Before treatment, the sapling stratum at the MNF plots was more abundant $(1,038$ stems/ha) and more diverse than at FEF (473 stems/ha). As a group, maples dominated this layer, but other species were also well-represented (e.g., American beech, black cherry, hickories, and American chestnut). The numbers of species found in the sapling layer increased by two between 1999 and 2007/2008, with three species added (devil's walking stick, sumac, 
and elderberry) and one species no longer found (dogwood) by 2007/2008. Maple species still dominated the sapling layer post-treatment (Table 3.5). Black birch was not abundant posttreatment, but when found, it occurred in plots that included fire treatments. Oak saplings were few in all plots post-treatment, with only chestnut oak and northern red oak found in Fence+Gap, and Fire+Fence+Gap plots.

\section{Treatment Effects - Seedlings}

\section{One-Way Effects}

For striped maple, fire*time was significant in explaining differences in relative abundance for both FEF and MNF plots when results were summed across other treatment factors (Tables 3.6 and 3.7). In both areas there were more striped maple seedlings before treatment than post-treatment in plots assigned to fire treatments ( $p<0.0001$ for FEF and MNF). Gaps increased the number of black birch seedlings between pre- and post-treatment measurement periods in the FEF plots ( $\mathrm{p}<0.0001$ ); gap*time was not significant for black birch seedlings on the MNF plots (Table 3.7). Fire increased the number of black birch seedlings over time in both areas $(\mathrm{p}<0.0001, \mathrm{FEF} ; \mathrm{p}=0.009, \mathrm{MNF})$. In both areas, gaps increased the relative abundance of yellow-poplar over time ( $p<0.0001, \mathrm{FEF}$ and $\mathrm{p}=0.003, \mathrm{MNF})$. When compared pre-treatment to post-treatment, fire also increased yellow-poplar seedling abundances in both areas ( $p<0.0001$ for FEF and MNF). Sugar maple seedlings did increase in relative abundance in both areas after fences were built ( $\mathrm{p}=0.006, \mathrm{FEF} ; \mathrm{p}=0.005, \mathrm{MNF})$.

When compared post treatment only, striped maple relative abundance was greater in plots without fire compared to those with fire ( $p=0.0001$, FEF plots; $p=0.001$, MNF plots). Red maple relative abundance on the FEF plots was affected by fire, fence, and gap when comparing pre-treatment to post-treatment (Table 3.6); however, when only post-treatment results were examined, only fire was significant $(\mathrm{p}<0.0001)$ with greater relative abundance without fire. On both FEF and MNF plots, sugar maple relative abundance was affected by browse control (Tables 3.6 and 3.7) with greater abundances found post treatment in plots with fences $(p=0.017$, FEF plots; $p=0.005, M N F)$.

Black birch relative abundance was greater in plots with fire compared to plots without (post treatment) $(\mathrm{p}=0.0001, \mathrm{FEF} ; \mathrm{p}=0.039, \mathrm{MNF})$ and greater in plots with gaps $(\mathrm{p}<0.0001$, FEF). In both FEF and MNF, yellow-poplar responded to fire and gap treatments with greater abundances in plots with fire ( $\mathrm{p}<0.0001$, FEF; $\mathrm{p}<0.0001, \mathrm{MNF})$ or with gaps $(\mathrm{p}<0.0001$, 
FEF; $\mathrm{p}=0.001, \mathrm{MNF}$ ) when post-treatment means are compared. At MNF, oak species relative abundance was greater pre-treatment than post when compared across all levels of all treatments (Table 3.7); no other factor significantly influenced the relative abundance of oak species.

\section{Two-Way Interactions}

Significant two-way interactions were found for some treatments and species when posttreatment means were compared. Striped maple and yellow-poplar on the FEF plots were found to be affected by gap and fire treatments (Figure 3.3) with greater abundance of striped maple in plots without fire and without canopy gaps ( $\mathrm{p}<0.0001)$, and yellow-poplar greatest on plots with fire and gaps $(\mathrm{p}<0.0001)$. The interacting effect of fire and gaps was the same for yellowpoplar on MNF plots with greatest abundance found in plots with both gaps and fire as compared to those with no gap or fire $(\mathrm{p}<0.0001$; Figure 3.4). For sugar maple on the FEF plots, fenced plots with no canopy gaps contained greater sugar maple than plots with no gap and no fence (p $=0.013$ ). Fencing combined with gaps did not benefit sugar maple (Figure 3.3).

\section{Individual Treatments}

When results were compared as eight separate treatments, sugar maple seedlings on the FEF plots were not affected by any treatment although both Fence and Fire+Fence treatments had greater sugar maple mean relative abundances than the other treatments (Figure 3.5). There were significant differences between treatments for sugar maple relative abundances on the MNF plots; both Control and Fire treatments had significantly lower relative abundance than all other treatments (Figure 3.6).

Post-treatment on the FEF plots, Fire+Gap plots had the lowest relative abundance of red maple and this treatment was significantly different than all non-fire treatments (Figure 3.5). The positive impact of fence and gap was reduced by the negative impact of fire for red maple in the FEF study area. There were no significant differences between treatments for red maple abundances in the MNF plots (Figure 3.6).

When the eight treatments are compared against each other post-treatment, only the Fire treatment is significantly different than all non-fire treatments on the FEF for striped maple abundance (Figure 3.5). However, the relative abundance of striped maple in the Fire plots is not statistically different than the relative abundances of the other treatments that include fire (Figure 3.5). On the MNF plots, striped maple relative abundance on the Fire+Fence+Gap treatment plots is significantly less than the Control, Fence, and Gap treatments (Figure 3.6). 
In the FEF plots, treatments that included disturbance to the canopy or forest floor resulted in greater black birch abundance than Control and Fence plots (Figure 3.5); on the MNF no treatments were significantly different for black birch abundance (Figure 3.6). Fire treatments increased the relative abundance of yellow-poplar seedlings on both study areas. This trend is clear in the comparison of individual treatments on the MNF plots with all fire treatments different than non-fire treatments but not statistically different from each other for average yellow-poplar relative abundance (Figure 3.6). The relationship is less clear for the FEF plots, where Fence+Gap and Gap treatments are not different than Fire, Fire+Fence, and Fire+Fence+Gap (Figure 3.5). There were no differences between individual treatments for oak species seedlings for FEF or MNF plots (Figures 3.5 and 3.6).

\section{Treatment Effects - Saplings}

\section{One-Way Effects}

For striped maple, fire*time was significant in explaining differences in both FEF and MNF plots (Tables 3.8 and 3.9). On the MNF plots there was a significant difference in striped maple IVs in plots assigned to fire treatments pre-treatment compared to post-treatment ( $\mathrm{p}<$ 0.0001) with greater striped maple IV before fire. For black birch, the interaction of gap*time was significant for both areas (Tables 3.8 and 3.9) with gaps increasing black birch from pretreatment levels ( $p<0.0001 \mathrm{FEF}$ and MNF plots). Fire increased the IV of black birch over time for the FEF plots $(\mathrm{p}<0.0001)$ but not on the MNF plots $(\mathrm{p}=0.536)$. Gap*time was significant for yellow-poplar IVs in both areas with gaps increasing yellow-poplar importance values in both areas over time ( $\mathrm{p}<0.0001 \mathrm{FEF} ; \mathrm{p}=0.0001 \mathrm{MNF}$ plots). Fire was also significant for yellow-poplar saplings with fire increasing yellow-poplar IVs on plots assigned to fires over time $(\mathrm{p}<0.0001 \mathrm{MNF} ; \mathrm{P}=0.0008$ FEF).

When examined post-treatment only, striped maple responded positively to gaps on both FEF and MNF plots with greater IVs on plots with gaps ( $p=0.0003$, FEF; $p<0.001, \mathrm{MNF})$ and IVs on MNF plots were reduced with fire $(\mathrm{p}<0.0001)$. Red maple IVs were reduced with fire ( $\mathrm{p}$ $<0.0001)$ and gaps $(\mathrm{p}=0.0052)$ on the FEF plots. On the FEF, black birch IVs increased in plots with browse control when compared to plots without ( $\mathrm{p}<0.0001)$. Yellow-poplar IVs were higher on plots with gaps on the FEF main plots ( $\mathrm{p}$ 0.0001) while on the MNF plots there were no significant one-way effects when post treatment means were compared. Oak IVs were higher on plots with browse control compared to those without $(\mathrm{p}=0.032)$ and higher on plots 
with gaps compared to those without when averaged across other treatment factors $(\mathrm{p}=0.032)$ on the MNF plots. Greater oak IVs were found on the FEF plots on plots without fire when compared to those with fire $(\mathrm{p}=0.042)$.

\section{Two-Way Interactions}

Significant two-way interactions were found for some treatments and species when posttreatment means were compared. A significant two-way interaction was found for red maple saplings on the FEF plots with lower IVs on plots with fire and gaps compared to plots with fire and no gap ( $\mathrm{p}=0.017$; Figure 3.7). For black birch on the FEF plots, the combination of gap and fence treatments resulted in lower IVs in plots with no gaps and no browse control as compared to plots with fences and gaps ( $\mathrm{p}=0.0003$; Figure 3.7). Also significant was the combination of gaps and fire with plots with no fire and no gap having lower black birch IVs than plots with gaps but no fire $(\mathrm{p}=0.0007 \mathrm{FEF})$. For striped maple on the MNF plots, IVs were greatest on plots with gaps and no fence when compared to those with no gap and no fence $(\mathrm{p}=0.0002$; Figure 3.8). Striped maple IVs were also lower on plots with fire and no gaps when compared to plots with gaps and no fire ( $<<0.0001$; Figure 3.8). IV for oak species combined on the MNF plots was greater for plots with fence and gaps as compared to plots with fence and no gaps $(\mathrm{p}=$ 0.008, Figure 3.8).

\section{Individual Treatments}

When compared across all eight treatments, in the post-treatment period, there were no differences between treatments for sugar maple sapling IVs for either the FEF or MNF plots (Figures 3.9 and 3.10). Red maple sapling IVs were significantly less on the Fire+Fence, Fire+Gap, and Fire+Fence+Gap plots compared to the other treatments on the FEF (Figure 3.9). On the MNF, no treatment effects alone or in combination were found to be significant in describing differences in red maple sapling IVs, and no individual treatment means were found to be significantly different post-treatment (Figure 3.10).

For striped maple on the FEF plots, IVs on Fire and Fire+Fence plots were significantly less than Fire+Gap and Gap treatments (Figure 3.9). On the MNF across the eight treatments, mean striped maple IVs on the Fire and Fire+Fence treatments were significantly less than the means for all other treatments although these two treatments did not differ from each other (Figure 3.10). 
Black birch saplings were not found in Fire, Control, Fence+Gap, Fire+Fence, and Fire+Gap plots (FEF study area) (Figure 3.9). Fire combined with fence and gap increased the average black birch sapling IV above Gap, Fire, Fence+Gap, Fire+Fence, and Fire+Gap treatments (Figure 3.9). On the MNF plots, no black birch saplings were found post treatment in Fire plots however this was not statistically different than the average values of any treatment other than Fence (Figure 3.10).

On the FEF plots, oak saplings were only found in Control and Fence+Gap plots and there were only a few individuals recorded (Figure 3.9). Oaks were only recorded in Fence+Gap and Fire+Fence+Gap plots on the MNF main plots (Figure 3.10).

\section{Discussion}

Three disturbance mechanisms were chosen for this study because they had the potential to impact the abundance of oak species and their principal competitors. Fire was hypothesized to cause a reduction in competitors and an increase in oak numbers, browse control was expected to benefit browse-sensitive species, and gap creation was expected to benefit oaks and other mid to shade intolerant species. The combinations of these three disturbances induced a range of changes in the seedling and sapling layers in these second-growth, oak-dominated forests.

Oak seedlings were not significantly affected by any factor other than time (FEF); oak saplings were negatively affected by fire and positively affected by fences. However, there were very few oak saplings before or after treatments were applied, so these results should be interpreted with caution. As for oak's competitors, red and striped maple seedlings and saplings were reduced by fire treatments; however sugar maple seedlings and saplings were not. Black birch and yellow-poplar seedlings increased as fire stimulated germination. The response of yellow-poplar to fire has also been found by others (Jackson and Buckley 2004, Schuler and others 2010) and fire is recommended for seedbed preparation for both yellow-poplar and black birch (Burns and Honkala 1990). All the competing species included in the study are prolific seeders with winged seeds to aid in dispersal (Burns and Honkala 1990). Yellow-poplar seeds retain viability in the forest floor for four to seven years (Burns and Honkala 1990) and birch seeds have been found to retain viability for more than a year while chestnut oak and Northern red oak were never found in the soil seed bank (Hille Ris Lambers and others 2005). Even short- 
term seed-banking can be advantageous to a species by increasing seedling survival (Hille Ris Lambers and Clark 2005).

The Gap treatment alone did not increase the seedling relative abundance or IV of any of the species assessed here, although gaps when combined with other factors did increase black birch and yellow-poplar seedlings and sapling IVs. This response increased competition for oaks species, already low in numbers, for site resources. Others have found that while thinning and prescribed fires created recruitment opportunities, maples occupied the gaps and oaks recruitment was minimal (Chiang and others 2008). In an oak-dominated old-growth fragment in Indiana, canopy gaps were not found to benefit oak saplings and other species with limited shade tolerance, in the sub canopy (Cowell and others 2010).

The original Fire-Fence-Gap study hypothesis that canopy gaps would benefit oak species may be overly simplistic. Without advanced oak regeneration able to take advantage of the opening, simply creating canopy gaps permits other species to use the additional sunlight reaching the forest floor. Small oak seedlings did not compete well with other advanced regeneration or regeneration from the seed bank when a canopy gap was formed. Oak species are considered moderately shade intolerant and oak regeneration is usually most abundant in gaps formed by multiple trees (Runkle 1982, Clinton and others 1994). For oak reproduction to exist, a series of critical events need to occur including: flowering, fruiting, seed dispersal, germination, seedling establishment, and dieback and sprouting (Johnson and others 2009). Oak regeneration accumulates in a forest as periodic seed crops add seedlings and previous year's seedlings dieback and resprout. The overall amount of regeneration generally decreases with increasing site quality. Capture of growing space released by a canopy gap by an oak usually requires the oak to be a seedling-sprout with a large root system able to respond with rapid shoot growth (Johnson and others 2009). The shoot portion of a seedling may be decades younger than the root system (Merz and Boyce 1956; Tryon and Powell 1984). The development of a competitive oak understory may take decades to develop (Cook and others 1998). While the study area has been accumulating oak seedlings (Table 3.1), the existing oak seedlings may not have had the root systems capable of supporting shoot growth required to successfully compete with other species after canopy gap creation.

Openings of about $1,640 \mathrm{~m}^{2}$ (150 feet in diameter) were found to contain adequate regeneration of oaks and other intolerant to moderately tolerant species (Smith 1981). In 
contrast, openings as small as $150 \mathrm{~m}^{2}$ have allowed northern red oak regeneration to advance to the overstory, although these stems were $3 \mathrm{~m}$ (10 ft) in height (Lorimer 1983) and oaks in the current study were much shorter. Treatment gaps in the present study were created by the death of multiple trees, and averaged about $250 \mathrm{~m}^{2}$. While canopy gaps of sufficient size were created, there was little large advanced oak regeneration in the study plots to take advantage of the increased light and compete with the other species also stimulated by the disturbance.

The third disturbance process examined in this study was seedling predation by larger mammals, chiefly deer. Because of their capacity to impact forest ecosystems directly and indirectly, deer are considered keystone herbivores (Rooney 2001). Female deer in West Virginia have been shown to have high site fidelity and low dispersal rates (Campbell and others 2004) which could mean that even in an area with low deer density overall, a specific site may be impacted by browse. Deer densities are usually given in number per unit area; however the social structure of female deer is described as overlapping home-ranges of female offspring (Porter and others 1991; Campbell and others 2004). Deer density in Tucker County (county of the study area) is estimated at 11-17 deer $/ \mathrm{km}^{2}$ (QDMA 2010) but is estimated as $6 \mathrm{deer} / \mathrm{km}^{2}$ for the FEF (Adams and others 2004).

Sugar and red maple, and yellow-poplar are considered preferred deer browse, striped maple and oaks considered intermediate, and black birch categorized as having low palatability (Knierim and others 1971). Others have classified striped maple as less sensitive to browse and a species that increases in abundance if deer densities are high (Tilghman 1989). However, there are differences in preferences based on overall food availability and season. For example, striped maple is categorized as highly preferred in late fall and winter but of moderate to low preference in other seasons (Horsley and others 2003). In the present study, black birch saplings on the FEF plots benefitted from fence treatments although when compared as a treatment alone, the results were not significantly different from the increased IV found in the Fire+Fence+Gap treatment. The control of deer browse did allow for greater sugar and red maple (preferred browse species) abundances compared to treatments where browse was not controlled. However, Fence as a treatment by itself did not show a significant increase for any species assessed here.

There were very few oak saplings before and after treatments and GLIMMIX models for oak seedlings and IVs had the poorest fit of all species. As stand-alone treatments or in 
combination with other treatments, fire and fence showed no effect on oak species seedling abundance. For saplings, there was a slight increase in oak sapling IV with gaps and fences compared to treatments without these elements, although, again, there were few individuals on which to base this conclusion.

Analysis of the herbaceous layer in these study areas found that gaps and fire increased species richness, cover, and diversity (Royo and others 2010). In those study plots where fire and gaps occurred and deer browse was excluded (Fire+Fence+Gap), the herbaceous layer was dominated by blackberry (Rubus allegheniensis) a shrub highly palatable to deer. With deer browse, this shrub was reduced, thereby increasing overall herbaceous richness. This reduction in blackberry is likely affecting the seedling and sapling layers as well. The increase in species richness in gaps may have decreased the IVs and abundances of some of the tree species assessed in this study due to the abundance of other species such as devil's walking stick.

The Fire-Fence-Gap study was replicated on the MeadWestvaco Wildlife and Ecosystem Research Forest (MWERF) in Randolph County, WV and analysis of those plots determined that fire alone had no significant effect, that birch seedling abundance was increased by gap creation, and red maple seedling abundance is reduced by fire (Nuttle and others in review). Sugar maple dominated the understory of these stands before treatment, and the study areas experienced only one prescribed fire. Very little northern red oak or chestnut oak existed in the overstory or understory before treatment (Collins and Carson 2003).

White-tailed deer density at the MWERF is estimated at 11.5-18.0 (Langdon 2001) or 12$20 \mathrm{deer} / \mathrm{km}^{2}$ (Campbell and others 2004), and Nuttle and others (in review) found that browsing was the main factor in reducing tree species regeneration at these sites. Deer browse was found to dramatically reduce the sprouting of top-killed saplings and diversity of sprouts after prescribed fire on the MWERF plots (Collins and Carson 2003). The white-tailed deer population on the FEF is estimated to be less than half the population on the MWERF. Lower browse pressure on the FEF and MNF study sites as compared to the MWERF allow for the influences of fire and canopy gaps to be determined.

The Canoe Run Study area, involving prescribed fire, is adjacent to the FEF plots of the Fire-Fence-Gap study. At Canoe Run, prescribed fire has been applied twice and browse has been controlled through fencing on some experimental plots. There were fewer red maple seedlings and more oak seedlings in burned areas of the study as compared to unburned areas. 
Fencing, however, had no significant effect on seedling abundances or diversity (Schuler and others unpublished). In the sapling layer, differences based on fire treatment were significant with greatly reduced abundances of maple species in burned areas compared to unburned areas. This adjacent study likely shares the same deer density as the Fire-Fence-Gap study reported here.

For land managers using prescribed fire to return a disturbance process to oak-dominated forests the results of the Fire-Fence-Gap study show that fire reduces maple relative abundance but also oak seedling abundance. As others have shown, one fire is not sufficient to reverse decades of fire suppression (Alexander and others 2008, Moser and others 1996; Johnson 1974) and this is even more important in mesic areas (Iverson and others 2008). A slow change in site conditions associated with the cessation of periodic fire has been termed mesophication by Nowacki and Abrams (2008). This is a positive feedback system whereby the exclusion of fire encourages the growth of shade-tolerant mesophytic hardwoods instead of oak and/or pines, resulting in a more closed canopy. As mesophytic species increase, the system becomes more fire-proof with dense shade and moist, cool microclimates, and fuels that are less conducive to burning. Schuler and others (2010) have further emphasized the importance of the mesophytic seed bank as barrier to oak restoration. The prospects of returning fire to this landscape are hampered because of the unfavorable microclimate, flammability of fuels, and loss of fireadapted species. Thus, one fire event may not reverse the slow creation of a shade tolerant understory after decades of fire suppression (Wendel and Smith 1986, Loftis 1990, Van Lear and Waldrop 1991).

When considering the role of canopy gaps in oak regeneration, canopy gaps are shown in this study to play a role in the development of oak forests as plots with fences and gaps had higher oak sapling IVs than plots without. This supports the findings of others in the development of the shelterwood-burn sequences to regenerate oak species (Brose and others 1999a, Brose and others 1999b).

The timing of interacting disturbance events may be the missing element in the FireFence-Gap study. Silvicultural prescriptions recommend overstory reduction or removal only after interfering vegetation has been removed often through fire or herbicide (Brose and others 2008; Johnson and others 2009). Canopy gaps were initiated just before prescribed fire, with fire applied at about the same time as canopy gaps were fully created through herbicide-induced 
death of overstory trees. The release of growing space and disturbance to forest floor was coincident with the dieback and sprouting of existing oak species in those experimental plots with fires and gaps. This created conditions where an oak seedling-sprouts likely faced the maximum pressure from competing vegetation.

The results of this study add to the growing body of information on the impacts of the three disturbance process alone and in combination in eastern oak-dominated forests. Also, the results highlight the need for further study of the timing of combined disturbances as silvicultural treatments to perpetuate oaks in oak-dominated forests undergoing successional replacement by shade-tolerant, fire-sensitive species. 


\section{Literature Cited}

Abrams, M.D. 1992. Fire and the development of oaks. BioScience 42(5): 346-353.

Abrams, M.D.; Downs J.A. 1990. Successional replacement of old-growth white oak by mixed mesophytic hardwoods in southwestern Pennsylvania. Canadian Journal of Forest Research 20: 1864-1870.

Adams, M.B; Burger, J.; Zelazny, L.; Baumgras, J. 2004. Description of the Fork Mountain long-term soil productivity study: site characterization. General Technical Report NE323. Newtown Square, PA: U.S. Department of Agriculture, Forest Service, Northeastern Research Station.

Alexander, H.D.; Arthur, M.A.; Loftis, D.L.; Green, S.R. 2008. Survival and growth of upland oak and co-occurring competitor seedlings following single and repeated prescribed fires. Forest Ecology and Management 256: 1021-1030.

Arthur, M.A.; Paratley, R.D.; Blankenship, B.A. 1998. Single and repeated fires affect survival and regeneration of woody and herbaceous species in an oak-pine forest. Journal of the Torrey Botanical Society 125(3): 225-236.

Barden, L.S. 1980. Tree replacement in a cove hardwood forest of the southern Appalachians. Oikos 35: 16-19.

Barden, L.S. 1983. Size, age, and growth rates of trees in canopy gaps of a cove hardwood forest in the southern Appalachians. Castanea 48(1): 19-23.

Barnes, T.A.; Van Lear, D.H. 1998. Prescribed fire effects on advanced regeneration in mixed hardwood stands, Southern Journal of Applied Forestry 22(3): 138-142.

Blankenship, B.A.; Arthur, M.A. 2006. Stand structure over 9 years in burned and fire-excluded oak stands on the Cumberland Plateau, Kentucky. Forest Ecology and Management 225: 134-145.

Brashears, M.B; Fajvan, M.A.; Schuler, T.M. 2004. An assessment of canopy stratification and tree species diversity following clearcutting in central Appalachian hardwoods. Forest Science 50(1): 54-64.

Brose, P.H.; Van Lear, D.H. 1998. Responses of hardwood advance regeneration to seasonal prescribed fires in oak-dominated shelterwood stands. Canadian Journal of Forest Research 28: 331-339.

Brose, P.; Van Lear, D.; Cooper, R. 1999a. Using shelterwood harvests and prescribed fire to regenerate oak stands on productive upland sites. Forest Ecology and Management 113: $125-141$. 
Brose, P.H.; Van Lear, D.H.; Keyser, P.D. 1999b. A shelterwood-burn technique for regenerating productive upland oak sites in the piedmont region. Southern Journal of Applied Forestry 23(3): 158-163.

Brose, P.; Van Lear, D. 1999. Effects of seasonal prescribed fires on residual overstory trees in oak-dominated shelterwood stands, Southern Journal of Applied Forestry 23(2): 88-93.

Brose, Patrick H.; Gottschalk, Kurt W.; Horsley, Stephen B.; Knopp, Peter D.; Kochenderfer, James N.; McGuinness, Barbara J.; Miller, Gary W.; Ristau, Todd E.; Stoleson, Scott H.; Stout, Susan L. 2008. Prescribing regenerationtreatments for mixed-oak forests in the Mid-Atlantic region. Gen. Tech. Rep. NRS-33. Newtown Square, PA: U.S. Department of Agriculture, Forest Service, Northern Research Station.

Burns, R.M.; Honkala, B.H., technical coordinators. 1990. Silvics of North America: 1. Conifers; 2. Hardwoods. Agriculture Handbook 654. U.S. Department of Agriculture, Forest Service, Washington, DC.

Busing, R.T. 2005. Tree mortality, canopy turnover, and woody detritus in old cove forests of the southern Appalachians. Ecology 86(1): 73-84.

Campbell. T.A.; Laseter, B.R.; Ford, W.M.; Miller, K.V. 2004. Feasibility of localized management to control white-tailed deer in forest regeneration areas. Wildlife Society Bulletin 32(4): 1124-1131.

Campbell, T.A.; Laseter, B.R.; Ford, W.M.; Odom, R.H.; Miller, K.V. 2006. Abiotic factors influencing deer browsing in West Virginia. Northern Journal of Applied Forestry 23(1): 20-26.

Chiang, J-M.; McEwan, R.W.; Yaussy, D.A.; Brown, K.J. 2008. The effects of prescribed fire and silvicultural thinning on the aboveground carbon stocks and net primary production of overstory trees in an oak-hickory ecosystem in southern Ohio. Forest Ecology and Management 255: 1584-1594.

Clatterbuck, W.K. 1998. Use of prescribed fire to promote oak regeneration. General Technical Report SRS-20, USDA Forest Service, Asheville, NC. In: Waldrop, TA, ed. Proceedings 9th biennial southern silvicultural research conference. Pp. 315-318.

Cleland, D.T.; Freeouf, J.A.; Keys, J.E., Jr.; Nowacki, G.J.; Carpenter, C; McNab, W.H. 2007. Ecological Subregions: Sections and Subsections of the Conterminous United States [1:3,500,000] [CD-ROM]. Sloan, A.M., cartog. General Technical Report WO-76. Washington, DC: USDA, Forest Service.

Clinton, B.D.; Boring, L.R.; Swank, W.T. 1994. Regeneration patterns in canopy gaps of mixed-oak forests of the southern Appalachians: Influences of topographic position and evergreen understory. American Midland Naturalist 132: 308-319. 
Collins, R.J.; Carson, W.P. 2003. The fire and oak hypothesis: incorporating the effects of deer browsing and canopy gaps. In: Proceedings of the $13^{\text {th }}$ Central Hardwood Forest Conference. Urbana-Champaign IL April 1-3 2003. St. Paul, MN: USDA Forest Service North Central Research Station General Technical Report, NC-234: 44-63.

Cook, J.E.; Sharik, T.L.; Smith, D.W. 1998. Oak regeneration in the southern Appalachians: Potential, problems, and possible solutions. Southern Journal of Applied Forestry 22(1): 11-18.

Cowell, C.M.; Hoalst-Pullen, N.; Jackson, M.T. 2010. The limited role of canopy gaps in the successional dynamics of a mature mixed Quercus forest remnant. Journal of Vegetation Science 21: 201-212.

Crow, T.R. 1988. Reproductive mode and mechanism for self-replacement of northern red oak (Quercus rubra) -- a review. Forest Science 34: 19-40.

Davis, M.B. 1981. Quaternary history and the stability of forest communities. In: West, D.C., H.H. Shugart, and D.B. Botkin, eds. Forest Succession: Concepts and Application. Springer-Verlag, New York. Pp. 132-153.

Elliot, K.J.; Hendrick, R.L.; Major, A.E.; Vose, J.M.; Swank, W.T. 1999. Vegetation dynamics after a prescribed fire in the southern Appalachians. Forest Ecology and Management 114: 199-213.

Ellsworth, J.W.; McComb, B.C. 2003. Potential effects of passenger pigeon flocks on the structure and composition of presettlement forests of eastern North America, Conservation Biology 17(6): 1548-1558.

Fei, S.; Steiner, K.C. 2007. Evidence for increasing red maple abundance in the eastern United States. Forest Science 53(4): 473-477.

Green, S.R.; Arthur, M.A.; Blankenship, B.A. 2010. Oak and red maple seedling survival and growth following periodic prescribed fire on xeric ridgetops on the Cumberland Plateau. Forest Ecology and Management 259: 2256-2266.

Hart, J.L.; Austin, D.A.; van de Gevel, S.L. 2010. Radial growth responses of three cooccurring species to small canopy disturbances in a secondary hardwood forest on the Cumberland Plateau, Tennessee. Physical Geography 31: 270-291.

Hart, J.L.; Grissinio-Mayer, H.D. 2009. Gap-scale disturbance processes in secondary hardwood stand on the Cumberland Plateau, Tennessee, USA. Plant Ecology 201: 131149. 
Hille Ris Lambers, J.; Clark, J.S. 2005. The benefits of seed banking for red maple (Acer rubrum): maximizing seedling recruitment. Canadian Journal of Forest Research 35: 806-813.

Hill Ris Lambers, J.; Clarck, J.S.; Lavine, M. 2005. Implications of seed banking for recruitment of southern Appalachian woody species. Ecology 86(1): 85-95.

Horsley, S.B.; Stout, S.L.; DeCalesta, D.S. 2003. White-tailed deer impact on the vegetation dynamics of a northern hardwood forest. Ecological Applications. 13(1): 98-118.

Iverson, L.R.; Hutchinson, T.F.; Prasad, A.M.; Peters, M.P. 2008. Thinning, fire, and oak regeneration across a heterogeneous landscape in the eastern US: 7-year results. Forest Ecology and Management 255:3035-3050.

Jackson, S.W.; Buckley, D.S. 2004. First-year effects of shelterwood cutting, wildlife thinning, and prescribed burning on oak regeneration and competitors in Tennessee oak-hickory forests. In: Connor, KF, ed., Proceedings 12th biennial southern silvicultural research conference. USDA Forest Service, Asheville, NC. General Technical Report SRS-71: 231-237.

Johnson, P.S. 1974. Survival and growth of northern red oak seedlings following a prescribed burn. USDA Forest Service North Central Forest Experiment Station, St. Paul, MN. Research Note NC-177.

Johnson, P.S.; Shifely, S.R.; Rogers, R. 2009. The ecology and silviculture of oaks, 2nd ed. Wallingford, UK: CABI Publishing.

Knierim, P.G.; Carvell, K.L.; Gill, J.D. 1971. Browse in thinned oak and cove hardwood stands. Journal of Wildlife Management. 35(1): 163-168.

Keyser, P.D.; Brose, P.; Van Lear, D.; Burtner, K.M. 1996. Enhancing oak regeneration with fire in shelterwood stands: preliminary trials. In: Wadsworth, $\mathrm{K}$ and McCabe, R., eds., Transactions of the 61st North American Wildlife and Natural Resources Conference. 215-219.

Langdon, C.A. 2001. A comparison of white-tailed deer population estimation methods in West Virginia. MS Thesis. West Virginia University, Morgantown, WV, USA.

Loftis, D.L. 1990. A shelterwood method for regenerating red oak in the southern Appalachians. Forest Science 36(4): 917-929.

Long, Z.T.; Pendergast IV, T.H.; Carson, W.P. 2007. The impact of deer on relationships between tree growth and mortality in an old-growth beech-maple forest. Forest Ecology and Management 252: 230-238. 
Lorimer, C.G. 1983. Eighty-year development of northern red oak after partial cutting in a mixed-species Wisconsin forest. Forest Science, 29(2): 371-383.

Lorimer, C.G. 1984. Development of red maple understory in northeastern oak forest. Forest Science 30: 3-22.

Lorimer, C.G. 1985. The role of fire in the perpetuation of oak forests. In: Johnson, J., ed. Proceedings of challenges in oak management and utilization, University of Wisconsin, Misc Publication: 8-25.

Lorimer, C. G. 1989. The oak regeneration problem: New evidence of causes and possible solutions. Forest Resource Analyses, no. 8. November 1989. Department of Forestry School of Natural Resources College of Agricultural and Life Sciences. University of Wisconsin-Madison. $31 \mathrm{p}$.

Lorimer, C.G.; Chapman, .J.W.; Lambert, W.D. 1994. Tall understorey vegetation as a factor in the poor development of oak seedlings beneath mature stands. Journal of Ecology 82: 227-237.

McCarthy, B.C.; Hammer, C.A; Kauffman, G.L.; Cantino, P.D. 1987. Vegetation patterns and structure of an old-growth forest in southeastern Ohio. Bulletin of the Torrey Botanical Club 114: 33-45.

McEwan, R.W.; Hutchinson, T.F.; Long, R.P.; Ford, R.D.; McCarthy, B.C. 2007. Temporal and spatial patterns in fire occurrence during the establishment of mixed-oak forests in eastern North America. Journal of Vegetation Science 18: 655-664.

McEwan, R.W.; Dyer, J.M.; Pederson, N. 2010. Multiple interacting ecosystem drivers: toward an encompassing hypothesis of oak forest dynamics across eastern North America. Ecography 33:1-13.

McGee, C.E. 1986. Loss of Quercus spp. dominance in an undisturbed old-growth forest. The Journal of the Elisha Mitchell Scientific Society 102: 10-15.

Merz, R.W.; Boyce, S.G. 1956. Age of oak “seedlings". Journal of Forestry 54(11): 664-775.

Moser, W.K.; Ducey, M.J.; Ashton, P.M.S. 1996. Effects of fire intensity on competitive dynamics between red and black oaks and mountain laurel. Northern Journal of Applied Forestry 13(3): 119-123.

Nowacki, G.J.; Abrams, M.D. 1992. Community, edaphic, and historical analysis of mixed oak forests of the Ridge and Valley Province in central Pennsylvania. Canadian Journal of Forest Research 22: 790-800.

Nowacki, G.J.; Abrams, M.D. 2008. The demise of fire and "mesophication" of forests in the eastern United States. BioScience 58(2):123-138. 
Nowacki, G.J.; Abrams, M.D.; Lorimer, C.G. 1990. Composition, structure, and historical development of northern red oak stands along an edaphic gradient in north-central Wisconsin. Forest Science 36: 276-292.

Nuttle, T.; Carson, W.P.; Adams, M.B. In review. Historic disturbance regimes promote tree diversity only under low browsing regimes in eastern deciduous forest. Ecology.

Pan, C.; Tajchman, S.J.; Kochenderfer, J.N. 1997. Dendroclimatological analysis of major forest species of the central Appalachians. Forest Ecology and Management 98: 77-87.

Porter, W.F.; Mathews, N.E.; Underwood, H.B.; Sage, Jr, R.W.; Behrend, D.F. 1991. Social organization in deer: implications for localized management. Environmental Management 15(6): 809-814.

Quality Deer Management Association (QDMA). 2010. Whitetail map. http://www.imaps.com/Qdma/frame/default1024_ie.asp?C=48449\&LinkID=0\&NID=0\&cmd=map\&T

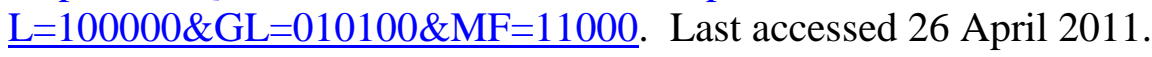

Rentch, J.S.; Fajvan, M.A.; Hicks R.R. 2003. Oak establishment and canopy accession strategies in five old-growth stands in the central hardwood forest region. Forest Ecology and Management 184: 285-297.

Rooney, T.P. 2001. Deer impacts on forest ecosystems: a North American perspective. Forestry 4(3): 201-208.

Royo, A.A.; Collins, R.; Adams, M.B.; Kirschbaum, C.; Carson, W.P. 2010. Pervasive interactions between ungulate browsers and disturbance regimes promote temperate forest herbaceous diversity. Ecology 91(1): 93-105.

Runkle, J.R. 1981. Gap regeneration in some old-growth forests of the eastern United States. Ecology 62(4): 1041-1051.

Runkle, J.R. 1982. Patterns of disturbance in some old-growth mesic forests of eastern North America. Ecology 63: 1533-1546.

Runkle, J.R. 1984. Development of woody vegetation in treefall gaps in a beech-sugar maple forest. Holarctic Ecology 7: 157-164.

Sander, I.L.; McGee, C.E.; Day, K.G.; Willard, R.E. 1983. Oak-hickory. In: Burns, R.M., technical coordinator. Silvicultural systems for the major forest types of the United States. Agricultural Handbook No. 445. Washington, DC: U.S. Department of Agriculture, Forest Service: 116-120.

SAS. 2006. SAS Enterprise Guide 4.1. SAS Institute Inc., Cary, NC, USA. 
Schuler, T.M.; Thomas-Van Gundy, M.A.; Adams, M.B.; Ford, W.M. 2010. Seed bank response to prescribed fire in the Central Appalachians. USDA Forest Service Northern Research Station, Research Paper NRS-9. Newtown Square, PA.

Schuler, T.M.; Thomas-Van Gundy, M.A.; Adams, M.B.; Ford, W.M. Unpublished. Evaluating prescribed fire in the Central Appalachians to facilitate mixed-oak forest sustainability.

Signell, S.A.; Abrams, M.D.; Hovis, J.C. 2005. Impacts of multiple fires on stand structure and tree regeneration in central Appalachian oak forests. Forest Ecology and Management 218: $146-158$.

Smith, H.C. 1981. Diameters of clearcut openings influence central Appalachian hardwood stem development - a 10-year study. USDA Forest Service, Northeastern Forest Experiment Station, Research paper NE-476. .

Smith, R.L. 1993. Wildlife of the upland forests. In: Stephenson, S.L., ed. Upland forests of West Virginia. McClain Printing Co., Parsons, WV.

Tilghman, N.G. 1989. Impacts of white-tailed deer on forest regeneration in northwestern Pennsylvania. Journal of Wildlife Management. 53(3): 524-532.

Tryon, E.H.; Powell, D.S. 1984. Root ages of advance hardwood reproduction. Forest Ecology and Management 8: 293-298.

Van Lear, D.H.; Waldrop, T.A. 1991. Prescribed burning for regeneration. Chapter 12. In: Duryea, M.L. and Doughertym P.M. eds. Forest regeneration manual. Kluwer Academic Press, Netherlands. Pp 235-250.

Watts, W.A. 1979. Late Quaternary vegetation of central Appalachia and the New Jersey coastal plain. Ecological Monographs 49(4): 427-469.

Wendel, G.W.; Smith, H.C. 1986. Effects of a prescribed fire in a central Appalachian oakhickory stand. Broomall, PA: USDA Forest Service, Northeastern Forest Experiment Station. Research Paper 594.

Wood, K.U.M. 2010. Ecological and economic impacts of wildfires on an Appalachian oak forest in southern West Virginal. M.S. Thesis, West Virginia University, Morgantown, WV.

Woods, F.W.; Shanks, R.E. 1959. Natural replacement of chestnut by other species in the Great Smoky Mountains National Park. Ecology 40(3): 349-361. 
Table 3.1 - Study area composition pre-treatment (1999) summarized by plot locations. Two study plots are on the Fernow Experimental Forest and two on the Monongahela National Forest.

\begin{tabular}{|c|c|c|c|c|c|c|c|}
\hline \multirow[t]{2}{*}{ Species } & \multicolumn{3}{|c|}{ stems/ha } & \multicolumn{3}{|c|}{ ba/ha } & \multirow{2}{*}{$\begin{array}{c}\text { stems/ha } \\
\text { Seedlings } \\
(>20 \mathrm{~cm})\end{array}$} \\
\hline & $12.7 \mathrm{~cm}+$ & $\begin{array}{c}2.54- \\
12.7 \mathrm{~cm}\end{array}$ & total & $\begin{array}{c}12.7 \mathrm{~cm} \\
+ \\
\end{array}$ & $\begin{array}{c}2.54- \\
12.7 \mathrm{~cm}\end{array}$ & total & \\
\hline & \multicolumn{7}{|c|}{ FEF } \\
\hline Maple & 207 & 361 & 568 & 9 & 1 & 10 & 7,817 \\
\hline Black birch & 5 & 2 & 7 & 0.5 & 0 & 0.5 & 130 \\
\hline American beech & 8 & 52 & 60 & 0 & 0 & 0 & 290 \\
\hline White ash & 8 & 2 & 10 & 1 & 0 & 1 & 140 \\
\hline Yellow-poplar & 22 & 1 & 22 & 2 & 0 & 2 & 0 \\
\hline Magnolia & 6 & 6 & 12 & 0 & 0 & 0 & 227 \\
\hline Black cherry & 6 & 0 & 6 & 1 & 0 & 1 & 83 \\
\hline Oaks & 95 & 1 & 96 & 22 & 0 & 22 & 3,420 \\
\hline Hickory & 14 & 2 & 15 & 1 & 0 & 1 & 0 \\
\hline American chestnut & & 1 & 1 & & 0 & 0 & 10 \\
\hline Grapevine & & 23 & 23 & & 0 & 0 & 197 \\
\hline $\begin{array}{l}\text { Mtn. laurel and } \\
\text { rhododendron }\end{array}$ & & 6 & 6 & & 0 & 0 & 17 \\
\hline Blueberry & & & & & & & 40 \\
\hline Other shrubs & & 4 & 4 & & 0 & 0 & 47 \\
\hline Other trees & 19 & 12 & 31 & 1 & 0 & 1 & 1,780 \\
\hline Other vines & & & & & & & 10 \\
\hline \multirow[t]{2}{*}{ Total } & 388 & 473 & 861 & 38 & 2 & 40 & 14,207 \\
\hline & \multicolumn{7}{|c|}{ MNF } \\
\hline Maple & 130 & 685 & 815 & 6 & 2 & 8 & 19,721 \\
\hline Black birch & 5 & 6 & 11 & 0 & 0 & 0 & 7 \\
\hline American beech & 4 & 19 & 22 & 0 & 0 & 0 & 146 \\
\hline White ash & 1 & 7 & 8 & 0 & 0 & 0 & 582 \\
\hline Yellow-poplar & 11 & 9 & 20 & 1 & 0 & 1 & 4 \\
\hline Magnolia & 6 & 11 & 17 & 0 & 0 & 0 & 54 \\
\hline Black cherry & 0.0 & 24 & 24 & 0 & 0 & 0 & 118 \\
\hline Oaks & 173 & 13 & 186 & 24 & 0 & 25 & 10,893 \\
\hline Hickory & 21 & 24 & 45 & 1 & 0 & 1 & 571 \\
\hline American chestnut & & 17 & 17 & & 0 & 0 & 1,464 \\
\hline Grapevine & & 1 & 1 & & 0 & 0 & 32 \\
\hline $\begin{array}{l}\text { Mtn. laurel and } \\
\text { rhododendron }\end{array}$ & & 1 & 1 & & 0 & 0 & 821 \\
\hline Blueberry & & & 0 & & & 0 & 1,339 \\
\hline Other shrubs & & 36 & 36 & & 0 & 0 & 818 \\
\hline Other trees & 12 & 184 & 196 & 0 & 0.5 & 1 & 6,221 \\
\hline Other vines & & & 0 & & & 0 & 18 \\
\hline Total & 362 & 1,038 & 1,400 & 33 & 3 & 36 & 42,811 \\
\hline
\end{tabular}


Table 3.2 - Post-treatment (2007/2008) mean seedling relative abundance by treatment for the Fernow Experimental Forest.

\begin{tabular}{l|rrrrrrrr}
\hline \multicolumn{1}{c|}{ Species } & \multicolumn{7}{c}{ Treatment } \\
& Control & Fence & Gap & Fence+Gap & Fire & Fire+Fence & Fire+Gap & Fire+Fence+gap \\
\hline Striped maple & 49.4 & 48.0 & 15.8 & 16.5 & 1.1 & 5.0 & 8.1 & 9.9 \\
Red maple & 15.2 & 4.1 & 8.9 & 17.0 & 0.6 & 0.3 & 0.0 & 2.5 \\
Sugar maple & 1.1 & 15.6 & 1.2 & 4.2 & 0.8 & 21.8 & 0.8 & 2.9 \\
Devil's walking stick & 0.0 & 0.0 & 0.1 & 1.3 & 3.1 & 10.4 & 6.1 & 11.7 \\
Black birch & 0.0 & 0.0 & 24.2 & 8.8 & 4.2 & 9.7 & 18.4 & 4.7 \\
American chestnut & 0.0 & 0.0 & 0.2 & 0.0 & 0.0 & 0.0 & 0.0 & 0.0 \\
America beech & 0.0 & 0.8 & 0.4 & 3.1 & 0.0 & 0.0 & 0.7 & 0.0 \\
White ash & 0.0 & 1.4 & 0.2 & 0.4 & 0.4 & 3.7 & 0.0 & 0.0 \\
Yellow-poplar & 0.0 & 0.0 & 5.2 & 8.9 & 31.7 & 21.7 & 41.2 & 28.6 \\
Magnolia species & 0.0 & 0.0 & 2.1 & 1.3 & 0.0 & 0.0 & 0.6 & 0.1 \\
Blackgum & 0.0 & 0.0 & 0.5 & 0.0 & 0.0 & 0.0 & 0.0 & 0.0 \\
Sourwood & 0.0 & 1.9 & 0.3 & 0.6 & 0.4 & 0.0 & 0.1 & 0.0 \\
Black cherry & 0.6 & 1.4 & 0.6 & 3.3 & 0.2 & 0.6 & 0.0 & 1.3 \\
White oak & 0.0 & 0.0 & 0.1 & 0.0 & 0.0 & 0.0 & 0.0 & 0.0 \\
Chestnut oak & 1.2 & 2.1 & 6.4 & 4.0 & 0.4 & 3.8 & 0.7 & 3.9 \\
N. red oak & 14.2 & 12.5 & 6.7 & 11.1 & 34.1 & 4.1 & 1.8 & 19.4 \\
Black locust & 0.0 & 0.0 & 0.1 & 3.0 & 0.0 & 1.0 & 3.1 & 1.0 \\
Sassafras & 14.7 & 7.9 & 25.3 & 13.6 & 20.6 & 6.0 & 4.6 & 0.9 \\
Basswood & 0.0 & 1.4 & 0.0 & 0.0 & 0.0 & 0.0 & 0.0 & 0.0 \\
Eastern hemlock & 0.0 & 0.0 & 0.1 & 0.0 & 0.0 & 0.0 & 0.0 & 0.0 \\
Grapevine & 0.0 & 0.0 & 0.8 & 1.3 & 1.6 & 4.5 & 7.3 & 9.5 \\
\hline
\end{tabular}


Table 3.3 - Post-treatment (2007/2008) mean seedling relative abundance by treatment for Monongahela National Forest plots.

\begin{tabular}{|c|c|c|c|c|c|c|c|c|}
\hline \multirow{2}{*}{ Species } & \multicolumn{8}{|c|}{ Treatment } \\
\hline & Control & Fence & Gap & Fence+Gap & Fire & Fire+Fence & Fire+Gap & Fire+Fence+Gap \\
\hline Striped maple & 47.0 & 71.6 & 52.0 & 17.0 & 26.4 & 15.1 & 23.2 & 8.1 \\
\hline Red maple & 7.7 & 7.1 & 13.2 & 13.5 & 1.9 & 8.6 & 1.3 & 3.6 \\
\hline Sugar maple & 0.0 & 3.0 & 0.9 & 4.9 & 0.0 & 1.7 & 0.1 & 0.2 \\
\hline Devil's walking stick & 0.0 & 0.0 & 0.0 & 0.0 & 0.1 & 0.9 & 0.0 & 2.0 \\
\hline Black birch & 0.0 & 0.0 & 1.0 & 3.2 & 17.2 & 1.8 & 14.9 & 2.3 \\
\hline American chestnut & 0.0 & 1.4 & 0.5 & 0.6 & 0.2 & 0.7 & 0.0 & 0.2 \\
\hline Dogwood & 0.0 & 0.0 & 0.0 & 0.0 & 1.0 & 0.7 & 0.1 & 5.5 \\
\hline America beech & 0.3 & 0.0 & 0.0 & 0.2 & 2.4 & 0.6 & 5.7 & 0.0 \\
\hline White ash & 10.5 & 1.7 & 1.2 & 2.7 & 0.0 & 0.0 & 0.7 & 1.6 \\
\hline Yellow-poplar & 0.0 & 0.0 & 0.2 & 2.3 & 28.6 & 30.1 & 40.2 & 36.8 \\
\hline Magnolia species & 0.0 & 0.4 & 0.2 & 0.1 & 0.0 & 0.7 & 1.0 & 0.6 \\
\hline Blackgum & 0.5 & 0.0 & 0.4 & 5.8 & 0.2 & 1.3 & 0.4 & 2.5 \\
\hline Sourwood & 0.0 & 0.0 & 0.0 & 0.0 & 0.0 & 0.4 & 0.0 & 0.3 \\
\hline White pine & 0.3 & 0.0 & 0.0 & 0.0 & 0.1 & 0.1 & 0.0 & 0.0 \\
\hline Black cherry & 0.0 & 0.2 & 0.6 & 2.2 & 0.4 & 1.2 & 0.0 & 0.8 \\
\hline White oak & 0.0 & 0.5 & 0.4 & 0.8 & 1.0 & 0.0 & 0.0 & 0.4 \\
\hline Chestnut oak & 0.0 & 0.2 & 4.4 & 2.8 & 0.0 & 1.5 & 0.0 & 1.1 \\
\hline N. red oak & 2.5 & 3.6 & 7.7 & 2.5 & 4.5 & 1.5 & 1.6 & 1.7 \\
\hline Black oak & 0.0 & 0.0 & 0.0 & 0.1 & 0.0 & 0.0 & 0.0 & 0.0 \\
\hline Black locust & 0.0 & 0.0 & 0.0 & 0.0 & 0.1 & 0.0 & 0.1 & 0.0 \\
\hline Sassafras & 0.2 & 0.0 & 0.0 & 1.4 & 2.4 & 13.0 & 0.9 & 8.1 \\
\hline Blueberry & 24.6 & 1.2 & 11.5 & 14.5 & 0.4 & 5.5 & 0.3 & 7.9 \\
\hline Grapevine & 0.0 & 0.0 & 1.7 & 0.1 & 3.7 & 1.6 & 4.6 & 3.8 \\
\hline
\end{tabular}


Table 3.4 - Post-treatment (2007/2008) mean sapling importance values (IV) by treatment for Fernow Experimental Forest plots.

\begin{tabular}{l|rrrrrrrr}
\hline \multicolumn{1}{c|}{ Species } & \multicolumn{1}{c}{ Treatment } \\
& Control & Fence & Gap & Fence+Gap & Fire & Fire+Fence & Fire+Gap & Fire+Fence+Gap \\
\hline Striped maple & 1.6 & 12.9 & 22.7 & 28.1 & 0.0 & 0.0 & 44.4 & 5.4 \\
Red maple & 18.7 & 12.1 & 14.9 & 20.1 & 32.2 & 0.0 & 0.0 & 0.0 \\
Sugar maple & 71.7 & 36.1 & 31.8 & 30.5 & 61.9 & 60.2 & 21.5 & 24.3 \\
Devil's walking stick & 0.0 & 0.0 & 0.0 & 4.0 & 0.0 & 10.3 & 23.0 & 24.7 \\
Black birch & 0.0 & 1.3 & 1.5 & 0.0 & 0.0 & 0.0 & 0.0 & 7.6 \\
White ash & 0.0 & 0.0 & 0.0 & 0.0 & 0.0 & 0.0 & 0.0 & 1.7 \\
American beech & 5.6 & 25.6 & 13.8 & 8.5 & 0.0 & 0.0 & 0.0 & 0.0 \\
Yellow-poplar & 0.0 & 0.0 & 5.1 & 2.1 & 0.0 & 0.0 & 3.5 & 18.1 \\
Magnolia species & 0.0 & 3.3 & 1.2 & 0.0 & 5.8 & 29.6 & 7.6 & 0.0 \\
Blackgum & 0.0 & 0.0 & 5.6 & 1.0 & 0.0 & 0.0 & 0.0 & 0.0 \\
Sourwood & 0.0 & 0.0 & 1.3 & 0.0 & 0.0 & 0.0 & 0.0 & 0.0 \\
N. red oak & 1.5 & 0.0 & 0.0 & 0.5 & 0.0 & 0.0 & 0.0 & 0.0 \\
Sassafras & 0.0 & 0.0 & 0.0 & 5.2 & 0.0 & 0.0 & 0.0 & 0.0 \\
Eastern hemlock & 0.0 & 6.3 & 0.0 & 0.0 & 0.0 & 0.0 & 0.0 & 0.0 \\
\hline
\end{tabular}


Table 3.5 - Post-treatment (2007/2008) mean sapling importance values (IV) by treatment for Monongahela National Forest plots.

\begin{tabular}{l|rrrrrrrr}
\hline \multicolumn{1}{c|}{ Species } & \multicolumn{1}{c}{ Treatment } \\
& Control & Fence & Gap & Fence+Gap & Fire & Fire+Fence & Fire+Gap & Fire+Fence+Gap \\
\hline Striped maple & 15.2 & 15.9 & 35.8 & 24.4 & 0.0 & 0.0 & 36.1 & 4.8 \\
Red maple & 40.8 & 43.4 & 20.0 & 34.6 & 42.2 & 23.6 & 6.8 & 12.9 \\
Sugar maple & 10.3 & 10.9 & 12.8 & 7.2 & 21.9 & 25.0 & 3.5 & 2.6 \\
Devil's walking stick & 2.4 & 1.2 & 0.5 & 2.8 & 0.0 & 0.0 & 2.0 & 0.8 \\
Black birch & 0.0 & 0.0 & 0.0 & 0.0 & 0.0 & 4.0 & 1.1 & 23.8 \\
American chestnut & 0.7 & 0.5 & 0.0 & 2.3 & 1.5 & 12.2 & 0.0 & 9.7 \\
Hickory species & 2.5 & 8.4 & 2.6 & 1.5 & 0.0 & 0.0 & 2.0 & 0.0 \\
White ash & 0.0 & 0.8 & 0.4 & 0.4 & 0.0 & 0.0 & 13.4 & 6.1 \\
American beech & 0.7 & 2.6 & 0.9 & 1.8 & 0.0 & 0.0 & 3.8 & 0.0 \\
Yellow-poplar & 5.1 & 1.2 & 1.0 & 0.0 & 0.0 & 3.0 & 2.2 & 4.9 \\
Magnolia species & 0.7 & 0.0 & 1.5 & 0.0 & 3.1 & 3.8 & 3.2 & 1.9 \\
Blackgum & 13.5 & 3.4 & 20.3 & 9.9 & 4.1 & 27.5 & 10.2 & 13.2 \\
Sourwood & 0.9 & 0.0 & 0.0 & 0.0 & 0.0 & 0.0 & 0.0 & 0.0 \\
White pine & 1.7 & 0.0 & 0.8 & 9.1 & 0.0 & 0.0 & 0.0 & 0.0 \\
Black cherry & 2.7 & 0.5 & 0.7 & 0.4 & 0.0 & 0.0 & 8.7 & 7.4 \\
Chestnut oak & 0.0 & 0.0 & 0.0 & 0.0 & 0.0 & 0.0 & 0.0 & 0.5 \\
N. red oak & 0.0 & 0.0 & 0.0 & 1.0 & 0.0 & 0.0 & 0.0 & 1.2 \\
Sassafras & 0.0 & 0.0 & 0.0 & 0.0 & 0.0 & 0.6 & 0.0 & 0.0 \\
\hline
\end{tabular}


Table 3.6 - Results of GLIMMIX model for mean seedling relative abundances for the Fernow Experimental Forest plots: relative abundances for maple species, black birch, yellow-poplar, and oak species.

\begin{tabular}{l|cccccc}
\hline \multirow{2}{*}{ Source } & $\begin{array}{c}\text { Striped } \\
\text { maple }\end{array}$ & $\begin{array}{c}\text { Red } \\
\text { maple }\end{array}$ & $\begin{array}{c}\text { Sugar } \\
\text { maple }\end{array}$ & $\begin{array}{c}\text { Black } \\
\text { birch }\end{array}$ & $\begin{array}{c}\text { Yellow- } \\
\text { poplar }\end{array}$ & $\begin{array}{c}\text { Oak } \\
\text { species }\end{array}$ \\
\cline { 2 - 7 } & $\mathbf{p}$ & $\mathbf{p}$ & $\mathbf{P}$ & $\mathbf{p}$ & $\mathbf{p}$ & $\mathbf{p}$ \\
\hline Time & $<.0001$ & $<.0001$ & 0.646 & $<.0001$ & $<.0001$ & 0.971 \\
Fire X time & 0.0002 & $<.0001$ & 0.003 & 0.0001 & $<.0001$ & 0.457 \\
Fence X time & 0.271 & 0.013 & 0.006 & 0.014 & 0.960 & 0.077 \\
Gap X time & 0.681 & 0.021 & 0.438 & $<.0001$ & $<.0001$ & 0.139 \\
Fence X gap X time & 0.517 & 0.081 & 0.038 & 0.309 & 0.850 & 0.364 \\
Fire X fence X time & 0.1223 & 0.991 & 0.239 & 0.009 & 0.467 & 0.214 \\
Fire X gap X time & 0.008 & 0.059 & 0.066 & 0.104 & $<.0001$ & 0.563 \\
Fire X fence X gap X time & 0.339 & 0.129 & 0.516 & 0.419 & 0.554 & 0.658 \\
\hline
\end{tabular}

Table 3.7 - Results of GLIMMIX model for mean seedling relative abundances for the Monongahela National Forest plots: relative abundances for maple species, black birch, yellowpoplar, and oak species.

\begin{tabular}{l|cccccc}
\hline \multirow{2}{*}{ Source } & $\begin{array}{c}\text { Striped } \\
\text { maple }\end{array}$ & $\begin{array}{c}\text { Red } \\
\text { maple }\end{array}$ & $\begin{array}{c}\text { Sugar } \\
\text { maple }\end{array}$ & $\begin{array}{c}\text { Black } \\
\text { birch }\end{array}$ & $\begin{array}{c}\text { Yellow- } \\
\text { poplar }\end{array}$ & $\begin{array}{c}\text { Oak } \\
\text { species }\end{array}$ \\
\cline { 2 - 6 } & $\mathbf{p}$ & $\mathbf{p}$ & $\mathbf{p}$ & $\mathbf{p}$ & $\mathbf{p}$ & $\mathbf{p}$ \\
\hline Time & $<.0001$ & 0.019 & 0.046 & 0.001 & $<.0001$ & 0.001 \\
Fire X time & 0.0002 & 0.177 & 0.840 & 0.009 & $<.0001$ & 0.063 \\
Fence X time & 0.606 & 0.755 & 0.006 & 0.028 & 0.175 & 0.745 \\
Gap X time & 0.118 & 0.308 & 0.465 & 0.853 & 0.003 & 0.403 \\
Fence X gap X time & 0.534 & 0.106 & 0.076 & 0.665 & 0.230 & 0.763 \\
Fire X fence X time & 0.518 & 0.586 & 0.308 & 0.011 & 0.041 & 0.753 \\
Fire X gap X time & 0.329 & 0.124 & 0.951 & 0.592 & 0.003 & 0.645 \\
Fire X fence X gap X time & 0.230 & 0.853 & 0.863 & 0.966 & 0.038 & 0.718 \\
\hline
\end{tabular}


Table 3.8 - Results of GLIMMIX model for maple species, black birch, yellow-poplar, and oak species mean sapling importance vales (IV) for the Fernow Experimental Forest plots.

\begin{tabular}{l|cccccc}
\hline \multirow{2}{*}{ Source } & $\begin{array}{c}\text { Striped } \\
\text { maple }\end{array}$ & $\begin{array}{c}\text { Red } \\
\text { maple }\end{array}$ & $\begin{array}{c}\text { Sugar } \\
\text { maple }\end{array}$ & $\begin{array}{c}\text { Black } \\
\text { birch }\end{array}$ & $\begin{array}{c}\text { Yellow- } \\
\text { poplar }\end{array}$ & $\begin{array}{c}\text { Oak } \\
\text { species }\end{array}$ \\
\cline { 2 - 7 } & $\mathbf{p}$ & $\mathbf{p}$ & $\mathbf{p}$ & $\mathbf{p}$ & $\mathbf{p}$ & $\mathbf{p}$ \\
\hline Time & 0.428 & $<.0001$ & 0.018 & 0.001 & $<.0001$ & 0.132 \\
Fire X time & 0.027 & 0.0002 & 0.0506 & 0.0003 & 0.826 & 0.001 \\
Fence X time & 0.002 & 0.381 & 0.527 & 0.001 & 0.443 & 0.583 \\
Gap X time & 0.008 & 0.0002 & 0.073 & 0.0003 & $<.0001$ & 0.099 \\
Fence X gap X time & 0.705 & 0.014 & 0.783 & 0.0003 & 0.446 & 0.001 \\
Fire X fence X time & 0.222 & 0.098 & 0.568 & 0.0003 & 0.877 & 0.099 \\
Fire X gap X time & 0.099 & 0.0001 & 0.511 & 0.001 & 0.826 & 0.583 \\
Fire X fence X gap X time & 0.411 & 0.112 & 0.426 & 0.001 & 0.811 & 0.132 \\
\hline
\end{tabular}

Table 3.9 - Results of GLIMMIX model for maple species, black birch, yellow-poplar, and oak species mean sapling importance values (IV) for the Monongahela National Forest plots

\begin{tabular}{l|rrrrrr}
\hline \multirow{2}{*}{ Source } & \multicolumn{1}{c}{$\begin{array}{c}\text { Striped } \\
\text { maple }\end{array}$} & $\begin{array}{c}\text { Red } \\
\text { maple }\end{array}$ & $\begin{array}{c}\text { Sugar } \\
\text { maple }\end{array}$ & $\begin{array}{c}\text { Black } \\
\text { birch }\end{array}$ & $\begin{array}{c}\text { Yellow- } \\
\text { poplar }\end{array}$ & \multicolumn{2}{c}{$\begin{array}{c}\text { Oak } \\
\text { species }\end{array}$} \\
\cline { 2 - 7 } & \multicolumn{1}{c}{$\mathbf{p}$} & $\mathbf{P}$ & $\mathbf{p}$ & $\mathbf{p}$ & $\mathbf{p}$ & \multicolumn{1}{c}{} \\
\hline Time & $<.0001$ & 0.102 & 0.986 & $<.0001$ & 0.0003 & 0.012 \\
Fire X time & $<.0001$ & 0.248 & 0.074 & 0.0003 & 0.004 & $<.0001$ \\
Fence X time & 0.815 & 0.874 & 0.098 & $<.0001$ & 0.002 & 0.046 \\
Gap X time & $<.0001$ & 0.072 & 0.273 & 0.008 & 0.003 & 0.005 \\
Fence X gap X time & 0.009 & 0.437 & 0.329 & 0.664 & 0.002 & 0.002 \\
Fire X fence X time & 0.144 & 0.812 & 0.674 & 0.014 & 0.0004 & 0.189 \\
Fire X gap X time & $<.0001$ & 0.069 & 0.100 & 0.002 & 0.008 & 0.727 \\
Fire X fence X gap X time & 0.035 & 0.298 & 0.063 & 0.795 & 0.269 & 0.924 \\
\hline
\end{tabular}


Figure 3.1 - General study area and locations of main plots.

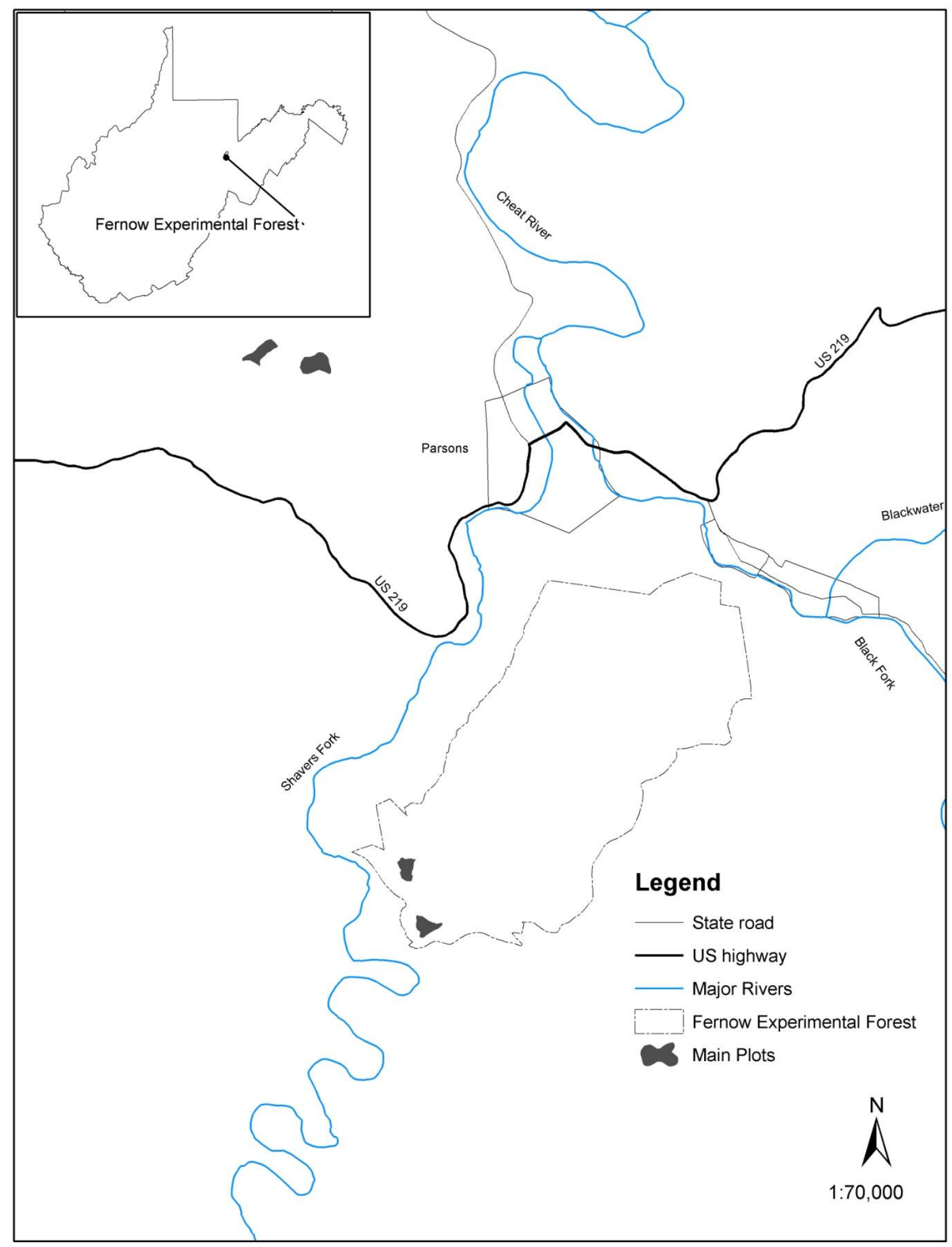


Figure 3.2 - Generalized treatment layout for one main plot. Fire was randomly assigned to one half of the plot. Gap and fence were randomly assigned to sampling plots.

Fire

No Fire

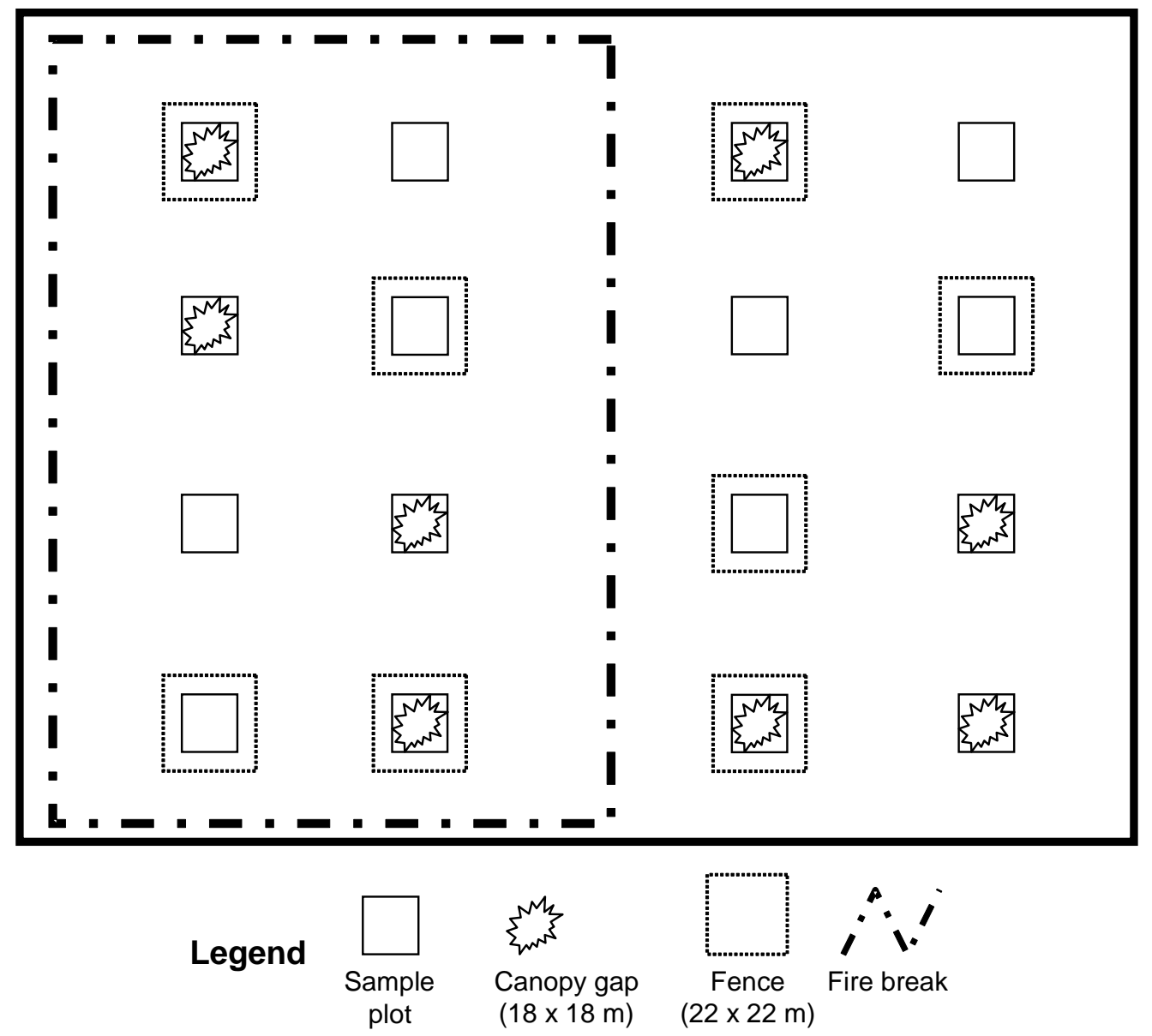


Figure 3.3 - Significant $(\alpha=0.05)$ two-way interactions for seedlings on Fernow Experimental Forest plots. All comparisons are made for the post-treatment time period only. Means $( \pm \mathrm{SE})$ are summarized across the third treatment factor.
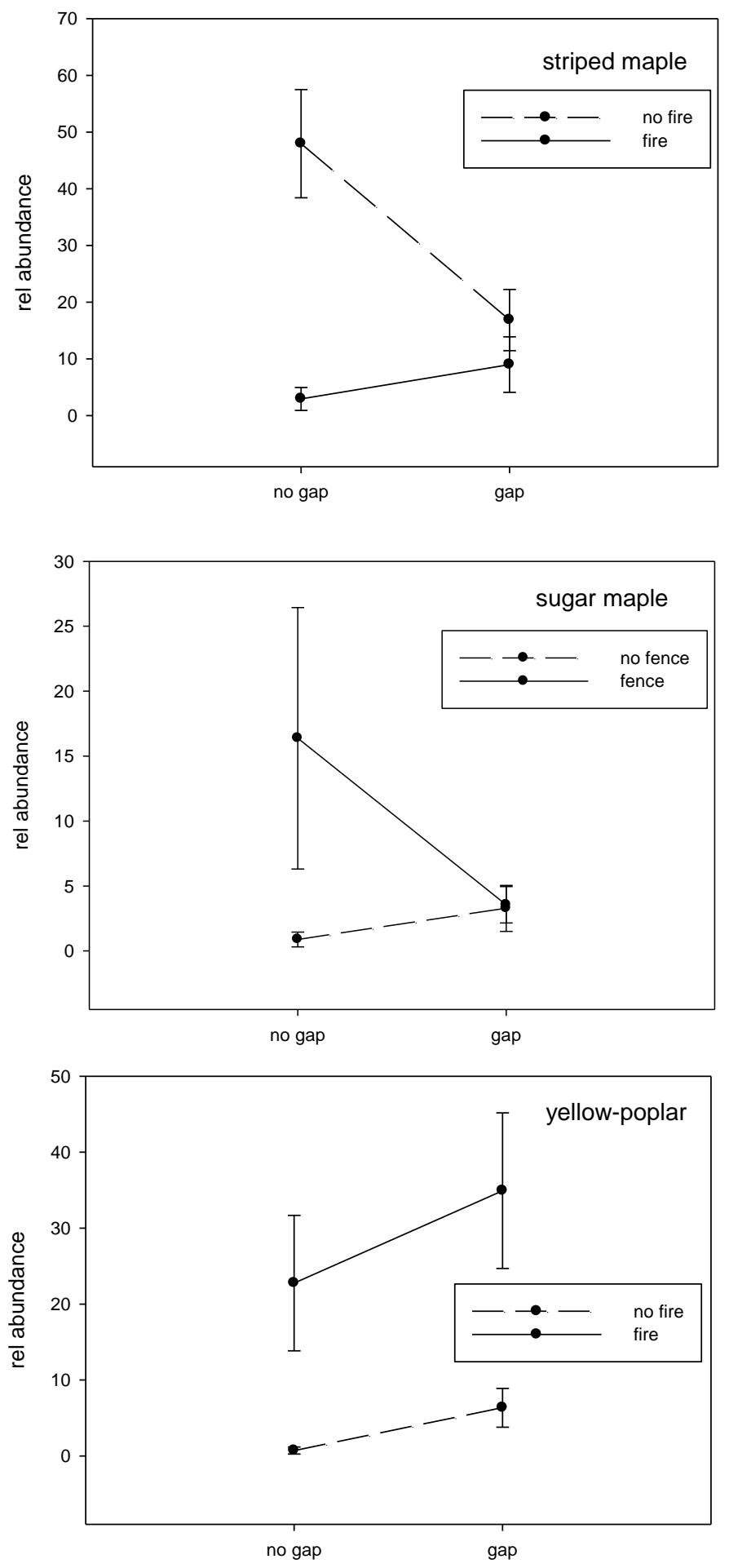
Figure 3.4 - Significant ( $\alpha=0.05$ ) two-way interactions for seedlings on Monongahela National Forest plots. All comparisons are made for the post-treatment time period only. Means $( \pm \mathrm{SE})$ are summarized across the third treatment factor.

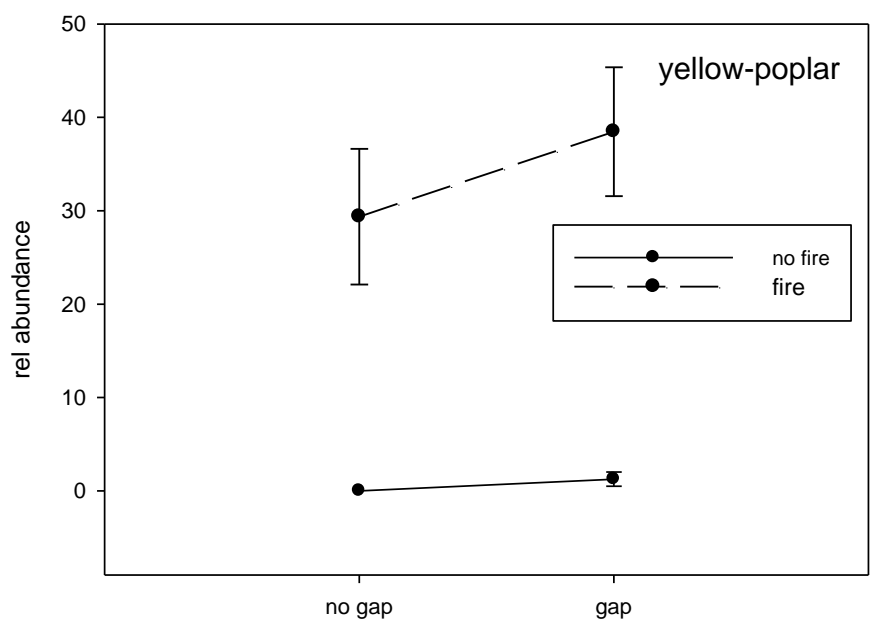


Figure 3.5 - Means $( \pm$ SE) of selected seedling relative abundances across the eight treatments on the Fernow Experimental Forest study plots post-treatment. Means with the same letter are not significantly different $(\alpha=0.05)$.
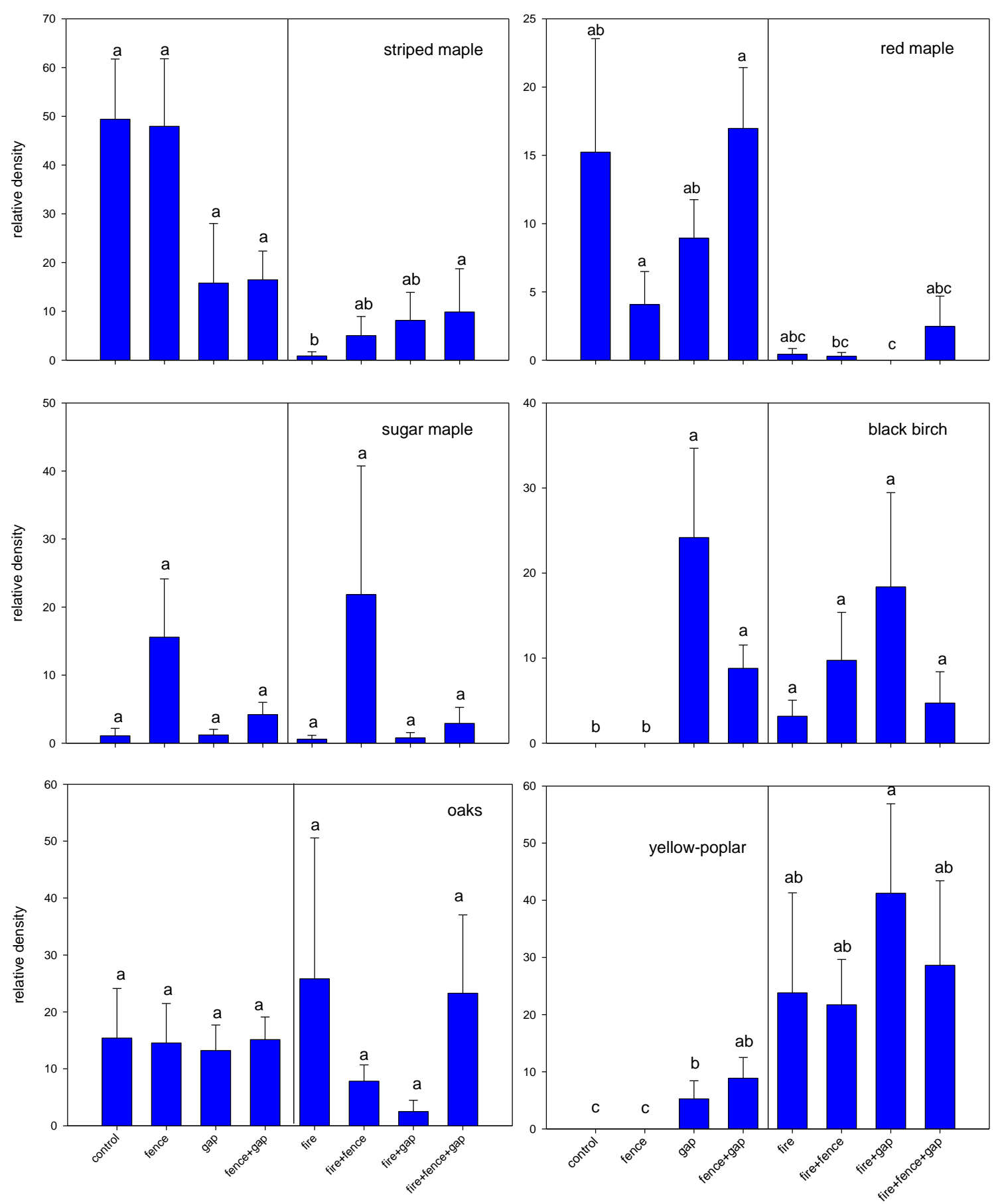
Figure 3.6 - Means $( \pm$ SE) of selected seedling relative abundances across the eight treatments on the Monongahela National Forest study plots post-treatment. Means with the same letter are not significantly different $(\alpha=0.05)$.
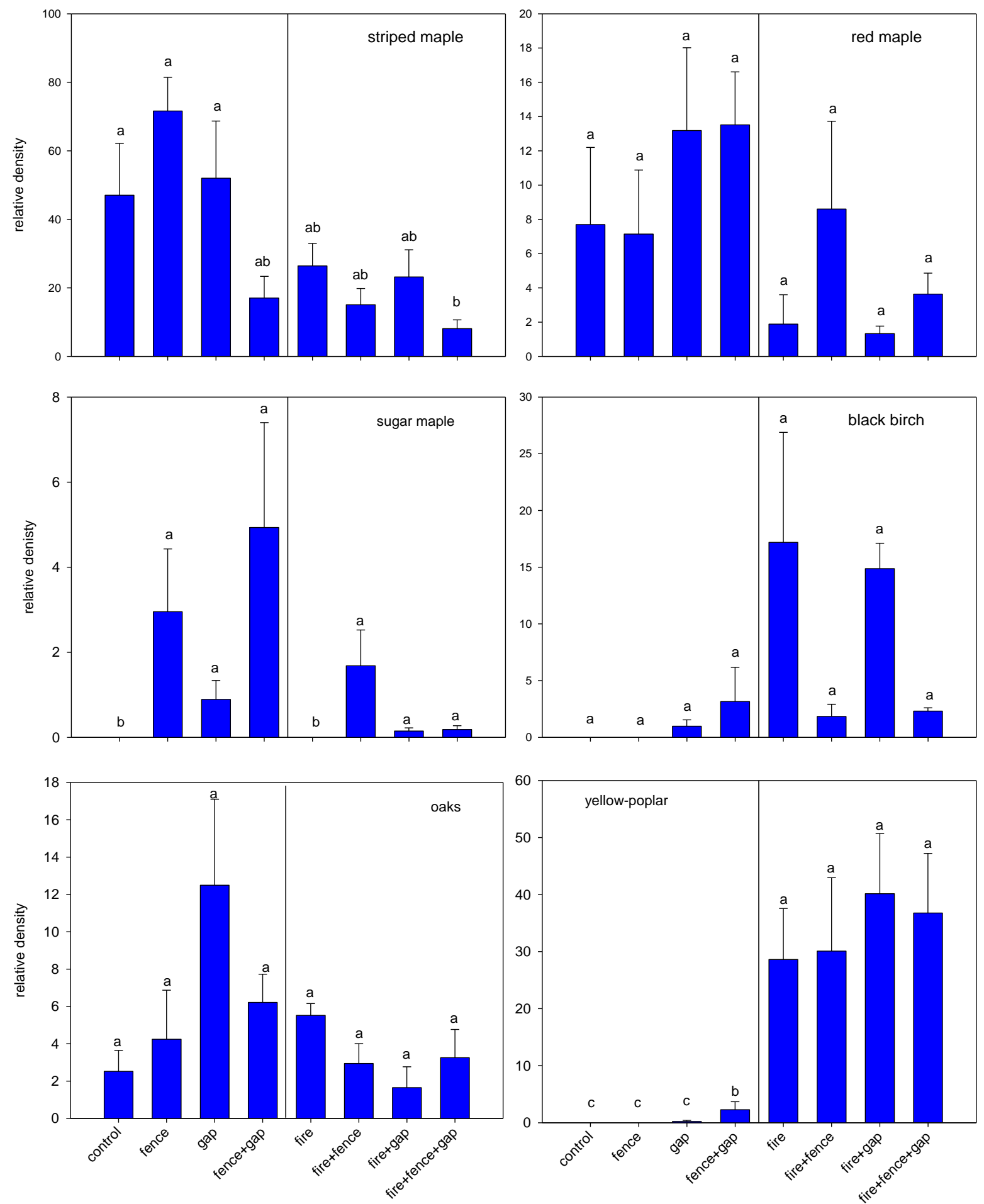
Figure 3.7 - Significant $(\alpha=0.05)$ two-way interactions for saplings on the Fernow Experimental Forest plots. All comparisons are made for the post-treatment time period only. Means $( \pm$ SE) are summarized across the third treatment factor.
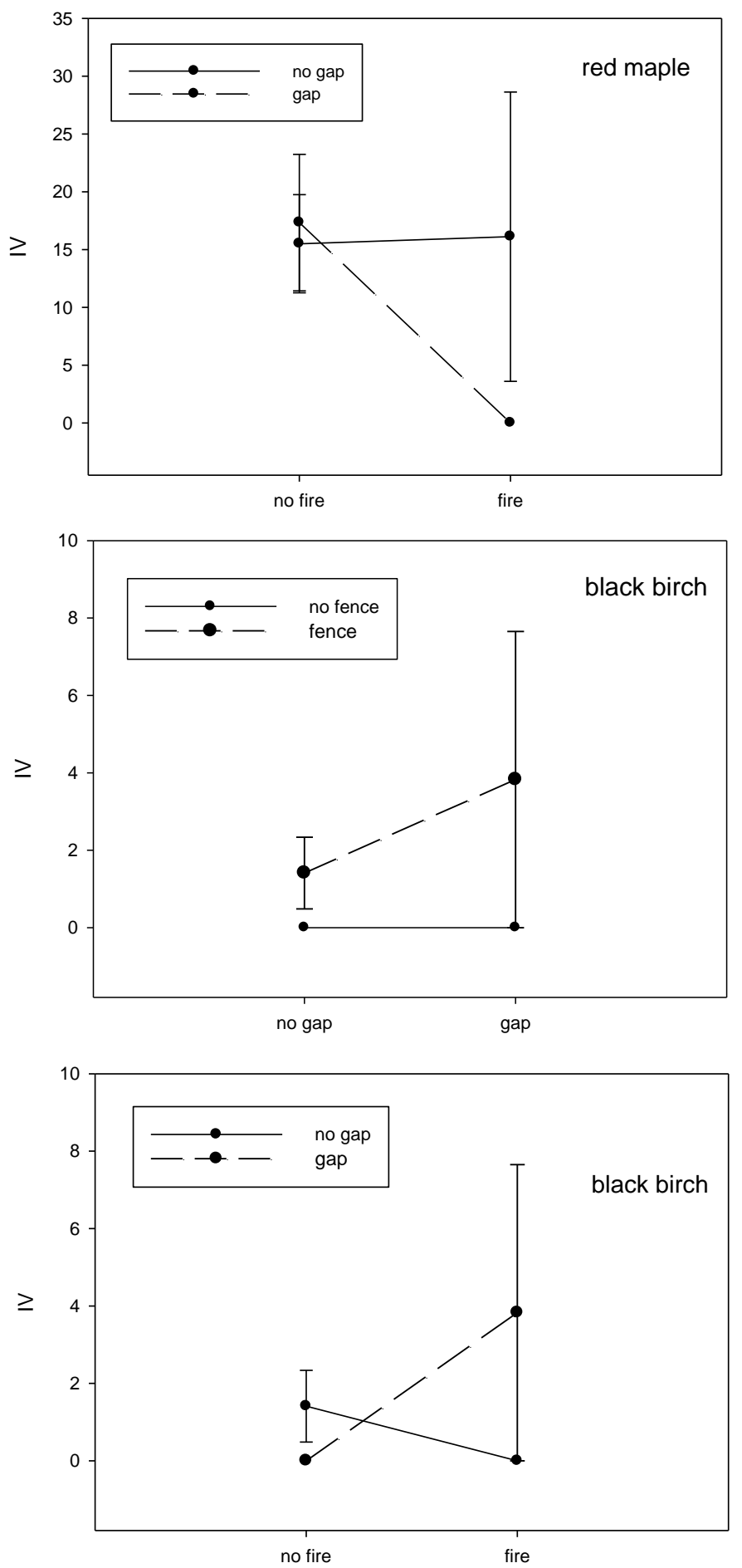
Figure 3.8 - Significant $(\alpha=0.05)$ two-way interactions for saplings on the Monongahela National Forest plots. All comparisons are made for the post-treatment time period only. Means $( \pm \mathrm{SE})$ are summarized across the third treatment factor.
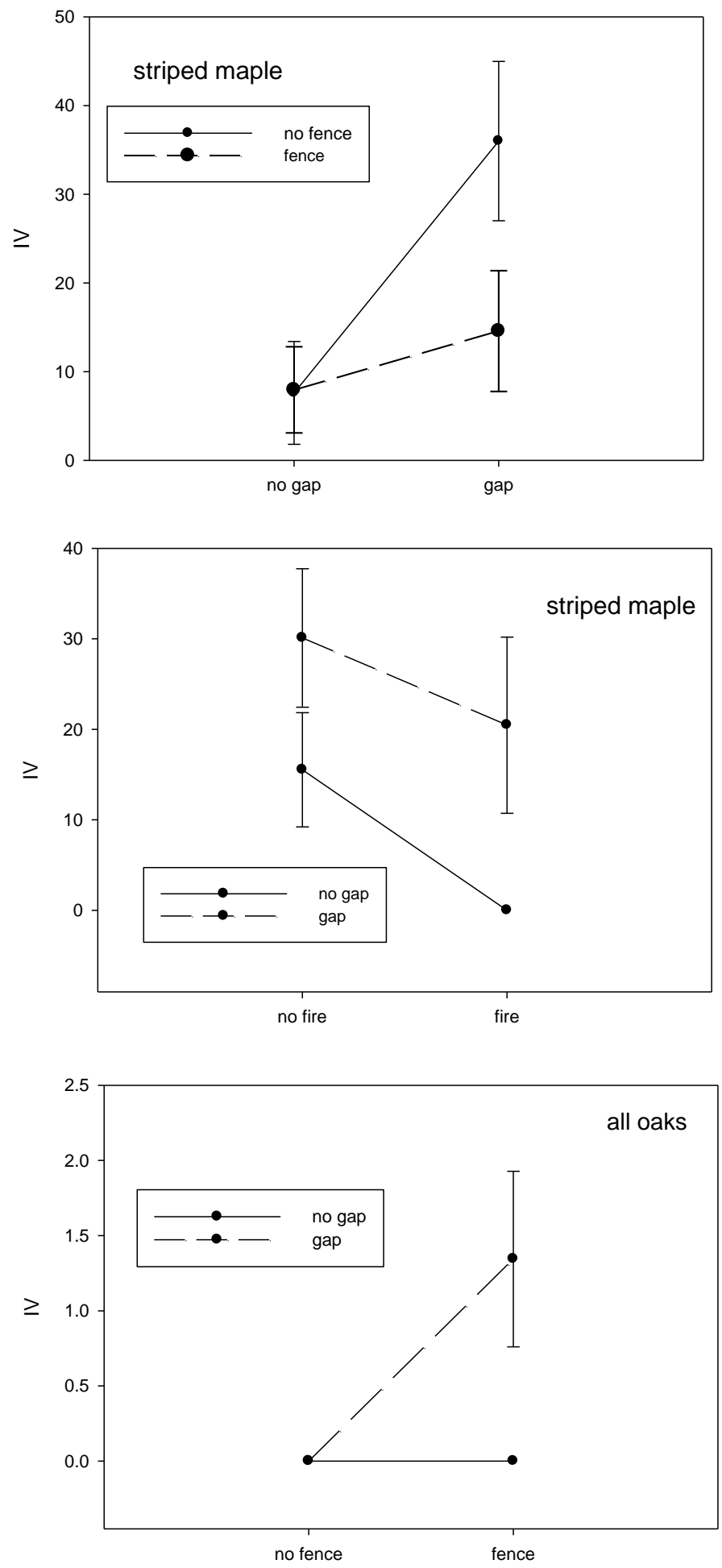
Figure 3.9 - Means ( \pm SE) of selected sapling IV across the eight treatments on the Fernow Experimental Forest study plots post-treatment. Means with the same letter are not significantly different $(\alpha=0.05)$.
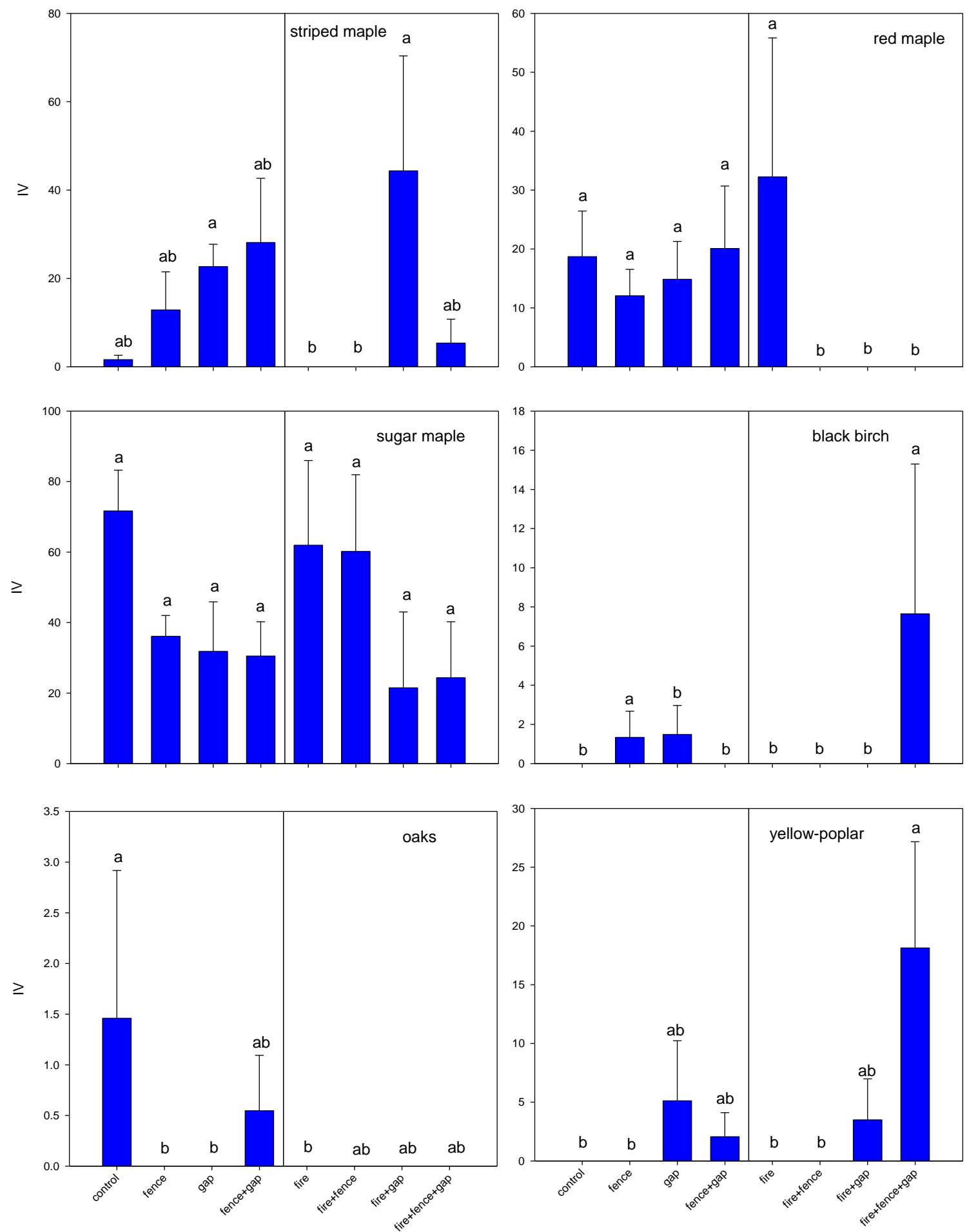
Figure 3.10 - Means ( \pm SE) of selected sapling IV across the eight treatments on the Monongahela National Forest plots post-treatment. Means with the same letter are not significantly different $(\alpha=0.05)$.
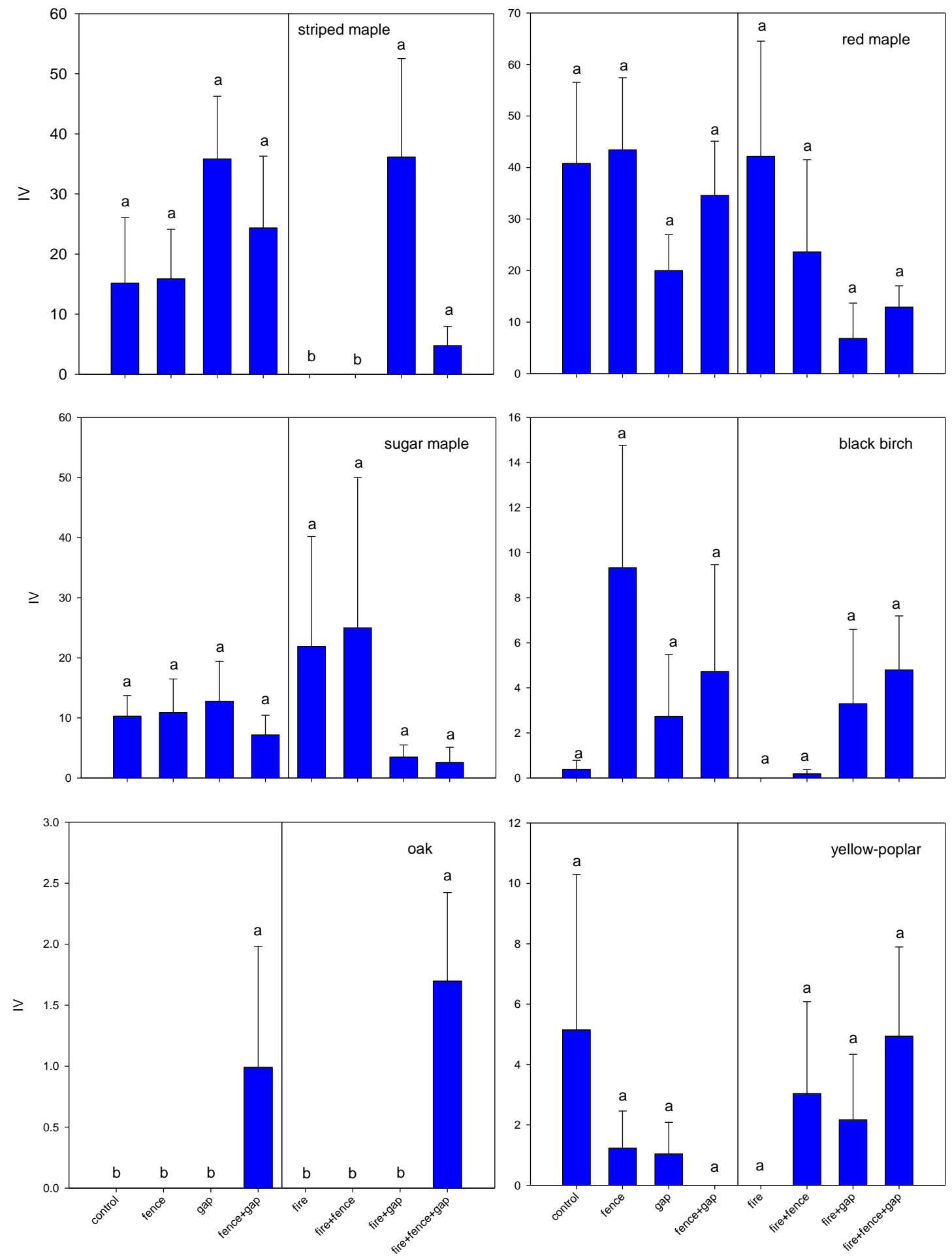
Chapter 4. Landscape-Scale Modeling of Red Spruce Restoration Alternatives

\begin{abstract}
An existing landscape-scale model, LANDIS-II, was configured for the implementation of red spruce restoration goals taken from the Monongahela National Forest (MNF) Forest Plan. Three harvest scenarios and one succession only scenario were simulated for 100 years. Harvests for all three scenarios were partial removal of selected species and cohorts in patches of 1 ha. Harvest scenarios differed in location of application with one scenario allowing harvest in all areas (S1), another restricting harvest to areas of low to moderate probability of Virginia northern flying squirrel habitat only (S2), and the third allowing harvest in all areas but excluding stands with $30 \%$ or greater red spruce 80 years or greater in age (S3); scenario 4 (S4) is succession only.

All scenarios resulted in the percentage of 1-19 year age class below the goal; however S3 was the closest at about $2 \%$ in the third decade. At year 30, the three harvest scenarios result in greater area in 20-39 year age class compared to succession only. Scenario 3 meets or slightly exceeds the lower limit of the MNF Forest Plan goal for this age class in years 40 through 70 . For the 40-79 year age class, S1 and S3 remained well above S2 and the succession-only scenario in years 30 through 90. At the end of the model period, S1, S2, and S4 meet the MNF Forest Plan goal for this age class. For the 80-119 year age class, the four scenarios start to differ in percent of area at year 20. During decades three through nine, S1 and S3 resulted in a consistent $40 \%$ of the area in this age class. All scenarios result in a landscape with much higher percentages of this age class than given as the MNF Forest Plan goal. Differences in the four scenarios for the 120 and greater age class occur starting at decade eight. For the last two decades of the model, the succession-only scenario results in greater amounts of area in this age class as compared to the harvest scenarios.
\end{abstract}

\title{
Introduction
}

Estimates of the extent of red spruce (Picea rubens)-dominated forests in West Virginia prior to European settlement range from 600,000 to 900,000 ha (Hopkins 1899; Stephenson 1993). Early $20^{\text {th }}$ century exploitative logging and subsequent fires in the spruce and sprucehardwood forests changed microsite conditions drastically and greatly reduced these forests to about 300,000 ha by 1865 and 90,000 ha by 1899 (Hopkins 1899) and approximately 24,000 ha by the 1990s (Stephenson 1993). With thin bark, shallow roots, and flammable resins, red spruce is ill-adapted to fire. In addition, red spruce occurs in landscape positions that rarely perpetuate surface fire, being cool, moist, and often shrouded in clouds or fog. Stand-initiating fires are possible in red spruce forests after mortality caused by insects or diseases coupled with drought and are infrequent in southeastern spruce-fir (Abies spp.) forests (Harmon 1981) and about every 500-1,000 years in New England spruce-fir forests (Fahey and Reiners 1981). 
Consequently, early $20^{\text {th }}$ century fires that occurred in logging slash had long-lasting negative impacts.

Natural restoration of these forests is hampered by the loss of red spruce seed source, slow maturity of red spruce to seed bearing age, and limited dispersal distance of seed (Pielke 1981). Spruce regeneration also is hampered by competition from abundant reproduction of hardwoods. However, red spruce is extremely shade tolerant and responds well to release even after decades of suppression (Korstian 1937; Hart 1959, Burns and Honkala 1990).

Silvicultural methods for increasing dominance and extent of red spruce have been suggested (Westveld 1953; Hornbeck and Kochenderfer 1998; Schuler and others 2002; Rentch and others 2007). Given the extreme shade tolerance of red spruce, Westveld (1953) recommended all-age management (single-tree selection) as the preferred silvicultural system. Shelterwood harvest can be successful if only one-half to one-third of the stand is removed (Westveld 1953). Seymour (2005) recommended an expanding-gap system that combined features of small gap dynamics (e.g., single-tree selection), more intensive shelterwood harvests, and retention of reserve trees. Due to shallow roots, the seed-tree method is not recommended and clearcutting is acceptable only when advanced regeneration is present (Westveldt 1953).

Hornbeck and Kochenderfer (1998) recommended removal of the overstory with possible retention of any canopy spruce or valuable hardwoods such as black cherry (Prunus serotina) to release a red spruce understory from a largely low-grade hardwood overstory. Areas of lowgrade hardwoods with red spruce regeneration may represent the best opportunity to easily increase the extent of spruce dominated forests in West Virginia.

Red spruce forests in West Virginia provide habitat for many plant and animal species including the federally threatened Cheat Mountain salamander (Plethodon netting; CMS) and the federally endangered Virginia northern flying squirrel (Glaucomys sabrinus fuscus; VNFS). Habitat models have been developed for these species to aid in recovery efforts and land management. The VNFS is a subspecies endemic to higher elevation forest in the Allegheny Mountains of eastern West Virginia and extreme northwestern Virginia. Red spruce and red spruce-northern hardwood forest types and elevation were found through logistic regression to predict VNFS occupation of a site (Menzel and others 2006). While CMS habitat will not be directly addressed with this landscape model, red spruce forests are a component of CMS habitat and model outputs may still be of interest for this species. 
Over two-thirds of high elevation red spruce and red spruce-hardwood forests in West Virginia are found on the MNF (Menzel and others 2006). Because of the known habitat for endangered or threatened species and the potential for restoration of red spruce, the MNF Forest Plan includes a management prescription for spruce-dominated forests (USDA 2006a). Restoration of these forests, both active and passive, is emphasized in management prescription MP 4.1. The overall vegetation goals for MP4.1 lands are to: maintain or enhance the spruce component within mixed spruce-hardwood communities, retain a hardwood component for hard mast, nesting habitat, and species diversity; restore red spruce to the overstory in stands with understory red spruce or sparse overstory red spruce; and restore the multi-aged structure of red spruce-dominated forests. To accomplish the restoration and maintenance goals, two-aged, uneven-aged, and stand improvement cuts are preferred silvicultural treatments. Two-aged silvicultural treatments suggested for the area include deferred rotation shelterwood harvests while the group selection method is suggested for uneven-aged management of these stands. Thinning is allowed in MP 4.1 with the restriction that at least $75 \%$ of the existing basal area be retained. The Forest Plan also permits planting of red spruce to meet restoration goals.

The Forest Plan objective for active management of red spruce-dominated stands is to enhance or restore red spruce on about 400 to 2,000 ha over the 10 year life of the plan. The Forest Plan includes guidelines and standards to direct this effort including: retention of culls and snags; manipulation of vegetation for red spruce restoration should occur in stands with understory red spruce or a nearby red spruce seed source; active management should occur in stands less than 80 years old and with less than $30 \%$ spruce in the overstory; no more than $40 \%$ of the forested area shall be harvested over a 10-year period; group selection harvests openings should be limited to 0.8 ha each; complete overstory removal should be avoided; prescribed fire will not be used in spruce restoration areas; and commercial moss collection is prohibited except for research or scientific purposes.

The restoration of red spruce-dominated forest communities on large blocks of federallyowned land represents an opportunity to test management actions to meet the goals of restoration at a landscape-scale. Stand-level actions designed to promote red spruce and continued succession of unmanaged areas can be aggregated in a landscape-scale model to determine if restoration goals can be met. To accomplish this, a model should be spatially dynamic to include ecological processes acting and interacting on the landscape. The LANDIS-II model of 
disturbance and succession (Scheller and others 2007) was chosen to simulate the ecological processes and proposed harvest disturbances in the red spruce-dominated forests of the study area. LANDIS-II was chosen because it can be used on large-scale landscapes $\left(10^{4}-10^{6}\right.$ ha $)$ over long times frames (50-1000 years), is raster-based, allows different processes to occur at varying time-steps, and has excellent user support (Mladenoff 2004). This model is not based on individual stems; rather it tracks species-age cohorts through time and space.

LANDIS-II has demonstrated usefulness in comparing management alternatives in oakhickory forests (Shifley and others 2000) and comparing the impacts of restoring fire to continued fire suppression in northern Minnesota (Scheller and others 2005). LANDIS-II was also used to simulate the interaction of climate change, wind, and harvesting on tree species migration and changes in forest composition (Scheller and Mladenoff 2005). Similar to the questions being addressed here, output from LANDIS-II has been used to compare habitat suitability for key wildlife species between management alternatives (Larson and others 2004; Shifley and others 2006).

I used LANDIS-II to simulate and project red spruce forest response to restoration actions based on direction in the MNF Forest Plan. Four restoration scenarios were created and modeled over 100 years: 1) harvest in stands regardless of potential for VNFS habitat (S1), 2) harvest in areas of low-to moderate probability of VNFS occupation only (S2), 3) harvest in all areas with the exclusion of some red spruce-dominated stands (S3), and 4) succession only (S4). S1 and S2 differ in protection given to VNFS habitat with high-probability VNFS habitat avoided in $\mathrm{S} 2$. In $\mathrm{S} 3$, stands that may already be naturally regenerating to red spruce are excluded from active management in an attempt to meet the Forest Plan guideline that active management should not occur in stands greater than 80 years old and with more than $30 \%$ spruce in the overstory. These scenarios were chosen out of many possible management scenarios to compare the results of avoiding impacts to VNFS habitat and established red spruce-dominated stands (S2 and S3) with the results of management in all possible stands (S1) and succession only (S4).

The objectives of this modeling exercise were to develop a LANDIS-II model of growth and change for the study area. With a base model developed that portrays succession, restoration scenarios involving active management to implement the MNF Forest Plan were created. The resulting landscapes from the three harvest scenarios were then compared to the results of 
succession only. Output from the scenarios will be compared to the forest type and age class distributions given in the MNF Forest Plan as desired future conditions. This analysis is intended to determine if desired future conditions outlined in the MNF Forest Plan can be reached via proposed limited harvest prescriptions and the length of time to reach this restoration goal.

\section{Study Area}

The MNF in eastern West Virginia has complex topography and it occurs mainly in the Allegheny Mountains and Ridge and Valley physiographic sections (Cleland and others 2007). The entire MNF spans a wide range of elevations, including the highest point in West Virginia (Spruce Knob at 1,482 m) and elevations as low as $275 \mathrm{~m}$. This complexity results in a variety of landforms and conditions supporting a high degree of vegetative diversity. Sedimentary rocks of Ordovician, Silurian, Devonian, Mississippian, and Pennsylvanian age underlie the MNF (USDA 2006b). Lithology includes sandstones, shales, siltstones, coal, and limestone and their differing rates of erosion create the varied topography of the study area. The study area encompasses the highest elevations of the MNF and totals approximately 62,000 ha, mainly in Greenbrier, Pocahontas, Randolph, Tucker, and Webster, counties. Most of the area in MP4.1 is above 975 m elevation and includes extremely acidic to acid soils with frigid temperature regimes, although soils are not exclusively frigid. Soil drainage ranges widely with diverse topography, including high elevation bogs.

The study area lies within two ecological subsections - the Northern High Allegheny Mountains and the Southern High Allegheny Mountains (Cleland and others 2007). Both subsections are generally cool and moist compared to the other subsections making up the greater $\mathrm{MNF}$, with an average annual maximum temperature of $14.5^{\circ} \mathrm{C}$ for the NHAM and $15.2^{\circ} \mathrm{C}$ for the SHAM and minimum average annual temperatures of $2.0^{\circ}$ and $2.4^{\circ} \mathrm{C}$ respectively (Cleland and others 2007). Average January minimum temperatures are the lowest for the subsections making up the entire MNF at $-9.4^{\circ} \mathrm{C}$ for NHAM and $-9.0^{\circ} \mathrm{C}$ for SHAM (Cleland and others 2007). Average annual snowfall ranges from $224.5 \mathrm{~cm}$ (SHAM) to $263.5 \mathrm{~cm}$ (NHAM) and average annual precipitation ranges from $128.2 \mathrm{~cm}$ (NHAM) to $138.1 \mathrm{~cm}$ (SHAM) (Cleland and others 2007). 
The extractive logging boom (and associated fires and soil loss) that reshaped the original forest of West Virginia occurred between 1870 and 1920, reaching a peak in 1909 (Stephenson 1993). However, even during European settlement in the late $18^{\text {th }}$ century, there was small-scale extraction as evidenced by the first sawmill in the study area in Tucker County in about 1776 (Stephenson 1993). In the upland areas of the MNF, commercial timber was first removed from areas close to navigable water starting around 1865 (Stephenson 1993). Whole-scale removal came about after narrow-gauge railroads were built into the remote upland forest starting around 1884 (Stephenson 1993) with the headwaters of the Greenbrier River in Pocahontas County reached by rail in 1903 (Lewis 1998).

For this modeling effort, National Forest land within the red spruce management prescription (MP4.1) was buffered by $5 \mathrm{~km}$ to reduce the influence of edge effects for a total of approximately 275,850 ha in the modeled area (Figure 4.1). Forest types and ages for privatelyowned land in this greater study area were not included in the initial forest conditions. Results presented here are only for National Forest land with the MP4.1 prescription (62,040 ha) and this is the actual study area for analysis with the larger landscape referred to as the model area. Based on MNF stand data as of 2006, about $49 \%$ of the red spruce-dominated stands were between 80-119 years old (Table 4.1).

\section{Methods}

\section{LANDIS-II parameters}

LANDIS-II is a spatially explicit model that simulates the dynamics of forest succession, species establishment, and disturbance events (fire, harvest, insects and disease) at a landscape scale (10,000 - 10,000,000 ha) and over long time frames (50 to 1,000 years). The model is stochastic and spatially dynamic in that modeled and species responses are affected by neighboring sites within the landscape. A key assumption of the model is that differences in species' life history attributes shape the species' response to disturbance events. The occurrence of disturbance events are not predicted through the model, but the model can be used to compare different disturbance and management scenarios in the long-term (He and others 2005, Larson and others 2004). In LANDIS-II, the landscape is modeled as a matrix of cells with species presence by 10-year age classes. 
Stand data (as of April 2006) from the MNF were summarized to create the initial community conditions for LANDIS-II. Stand forest types and ages were used to create 42 forested communities that differed in species composition and age structure (Table 4.2). Single species forest types likely include other species, however more specific data were not easily derived from the MNF stand data. Each stand polygon was assigned a community type and the polygon feature layer was converted to raster with cell size of 50 by $50 \mathrm{~m}$. This stand data was used to create the initial conditions map of species and age cohorts and the stand boundaries map for input into LANDIS-II.

LANDIS-II allows for stratification by landtype or ecoregion to model heterogeneity of climate and disturbance regimes. Ecological subsections (Cleland and others 2007) were used as ecoregions to capture the variety of site conditions found in the study area. The model and study areas cover two subsections - Northern High Allegheny Mountains (NHAM) and Southern High Allegheny Mountains (SHAM) and stands were assigned to only one subsection if they crossed the subsection border. Climate and soils data for each ecoregion are used to parameterize the model for calculation of seedling establishment probabilities.

Modeling of species responses to disturbance required that individual species characteristics be entered in the model. For each species listed in the initial forest communities, longevity, age of maturity, shade tolerance class, fire tolerance class, effective seeding distance, maximum seeding distance, vegetative reproduction probability, and minimum age of vegetative reproduction were determined through literature review (Table 4.3; Burns and Honkala 1990; Brown 1996; He and Mladenoff 1999; Lorimer and others 2001; USDA NRCS 2002; Kitamura and others 2003; Nesom 2006).

The probabilities of seedling establishment for each species modeled and in each ecoregion were determined through a LANDIS-II calculator based on the LINKAGES model (Tables 4.4 and 4.5; Pastor and Post 1985). While LANDIS-II itself is cohort-based, the seedling establishment probabilities by species were obtained from an individual tree-based model. The probability calculator estimated four modifiers to the base probability that were assumed to alter the probability of establishment; growing degree days, drought tolerance, minimum January temperature, and nitrogen tolerance. Nitrogen sensitivity for the calculation of species establishment probabilities refers to a species response to low levels of nitrogen (Table 4.4). Input for this modifier was 1, 2, or 3 with 1 given to species intolerant of low levels of nitrogen 
and 3 tolerant of low nitrogen levels. The rankings used for this project were from another forest dynamics model, JABOWA (Botkin 1993), based on work in northern hardwoods in New England.

Average minimum, maximum, and total monthly temperatures (and associated standard deviation) for the calculation of seedling establishment probabilities were summarized from data obtained electronically from the National Climatic Data Center (NOAA 2009) (Table 4.5). Temperature data for the NHAM ecoregion were summarized from August 1948 to June 1996 from a weather station at Canaan, West Virginia (Tucker County) located at $39^{\circ} 03^{\prime} \mathrm{N}$ and $79^{\circ} 25^{\prime} \mathrm{W}$ and $990 \mathrm{~m}$ elevation. Climate data for the SHAM ecoregion were summarized from December 1985 to January 2009 from the weather station at Richwood, West Virginia (Nicholas County) located at $38^{\circ} 12^{\prime} \mathrm{N}$ and $80^{\circ} 13^{\prime} \mathrm{W}$, with an elevation of approximately $942 \mathrm{~m}$.

Soil parameters for the calculation of probability of seedling establishment included field capacity, wilting point, and base soil nitrogen (Table 4.5). I used data from soil pits on the MNF in high elevation spruce sites to populate these parameters. Soil water characteristics were estimated using soil texture and organic matter content in the Soil Water Characteristics calculator version 6.02.74 (Saxton and Rawls 2006).

The Biomass Succession version 2.2 extension for LANDIS-II was used to project growth and competition for both the harvest scenarios and the succession only scenario. As it is used in LANDIS-II, biomass is more than simply a summation of living and dead matter on a site at any given time. Biomass can be viewed as a record of disturbance events and site factors that occur at both small and large scales (Scheller and Mladenoff 2004). Small-scale ecosystem processes and large-scale landscape process are integrated in the growth and decomposition of stand biomass (Scheller and Mladenoff 2004). The other succession option for LANDIS-II is based on age only with mortality a function of maximum species age with an increasing probability of random mortality after the species-age cohort has passed $80 \%$ of its maximum age. The biomass succession extension was designed to minimize complexity requiring a low number of parameters that can be estimated across an entire landscape and supplement the species-age cohort framework.

The biomass succession module tracks how cohorts reproduce, age, and die through calculation of biomass and using changes in biomass as a proxy for competition. The algorithms model the cell cohorts through biomass build-up and decline over time. Parameters for this 
extension include: a seeding algorithm; minimum relative biomass by shade class; probability of establishment by species shade class and by site shade level; leaf lignin content; woody decay rate; mortality curve shape; leaf longevity; maximum annual net primary productivity; and maximum biomass.

The probability of a seed arriving at a site is based on effective and maximum seeding distances by species and the algorithm using these distances to calculate a probability was the same for all species, the Ward seeding algorithm (Ward and others 2005). The probability of establishment is modeled separately for each species starting with a determination of light conditions present, the species' light requirements, and if the species can establish itself on the site (Table 4.6). Seeds come into a site from neighboring seed sources. A neighboring site serves as a seed source if at least one cohort of the same species is older than the age of maturity and the distance to the site is less than or equal to the maximum seeding distance plus the cell size.

LANDIS-II tracks the shade developing on each cell by comparing existing biomass to a table of thresholds of biomass that are expressed as a percentage of maximum possible biomass for that cell. The thresholds are the lower bounds of biomass, of any species, required for a site to move to the next shade class. The thresholds used for these simulations were set the same for both ecoregions and were set at LANDIS-II defaults with class one at 15\%, class two at 30\%, class 3 at $40 \%$, class 4 at $80 \%$, and class 5 at 95\%. These breakpoints create a relatively low threshold for shade classes 1 and 2, a large range for the moderate shade class (40 to 80\% shade), and little difference between the classes with the greatest shade.

Woody decay rates and leaf lignin content were obtained from published sources (Tyrell and Crow 1994; NERC 2011). Leaf longevity, the residence time for leaves and needles on the forest floor, was set at one year for hardwoods and four years for red spruce and hemlock. These parameters are used in the calculations of dead biomass, which will not be reported from this analysis, but were required for the model to run.

Maximum biomass and annual net primary productivity (Table 4.7) were taken from published estimates based on forest types (Jenkins and others 2001). Competition between species is based on the accumulation of biomass as influenced by age-related mortality. The mortality curve parameter required by the model (Table 4.7) describes when age-related mortality begins by species with a lower bound of $10 \%$ of life span and an upper of $85 \%$ of 
lifespan. General silvics references were used to estimate the start of age-related mortality for each species (Fowells 1965; Burns and Honkala 1990; Hicks 1998). When no information could be found for a species, a default of $67 \%$ of lifespan was used. For each species, longevity was multiplied by 10 and $85 \%$ to get the ages for the parameters of 5 and 25 (endpoints for model input). These ages and corresponding parameters were plotted for each species and linear equations developed for these data. The resulting equations were then used to find the model parameter corresponding to the beginning age of age-related mortality found or estimated from literature.

\section{LANDIS-II Prescription and Scenarios}

There are several ways to construct harvest prescriptions in LANDIS-II. Constraints can be entered in model commands that affect the ranking and qualification of a stand for harvest. Based on the general goals and objectives in the MNF Forest Plan, active management in the study area was assumed to target those stands with existing understory red spruce or with overstory red spruce nearby as a seed source. Therefore, I included parameters in the harvest commands to both give priority to those stands with existing red spruce, and to ensure that no red spruce cohorts were removed with the harvests. To target stands with existing red spruce, the model required that at least $10-30 \%$ of cells making up the stand be in red spruce ages 1-300 years in order to be selected for harvest in two scenarios (S1 and S2). Without the added parameters to target red spruce stands, preliminary runs of the model did not create many openings within stands with existing red spruce. The MNF Forest Plan (USDA 2006a) includes a guideline stating that active management will not occur in stands 80 years and older where red spruce comprised $30 \%$ or more of the overstory. This guideline was included in the harvest scenario S3 as a constraint. As there is no way to set an age limit for only one forest type since LANDIS-II relies on species-age cohort combinations, this guideline was incorporated into a LANDIS-II scenario as the exclusion of stands with $30 \%$ or greater red spruce of 80 years or older. This makes the assumption that red spruce 80 years and older are in the overstory of these stands.

Stands were ranked for harvest through the use of species economic rankings. Red spruce and northern hardwood species were given high economic rankings although, again, no red spruce was removed by the harvests, so that harvests would occur in stands with existing red 
spruce. This method also gives greater weights to older cohorts. For this simulation, economic ranking was used as a stand-in for desired tree species.

After stands are determined to be qualified for harvest and ranked, the prescription is applied. The active restoration prescription applied for this study consisted of patch openings of up to 1 ha, with openings making up $30 \%$ of the stand area of targeted stands. Stands had to be at least 50 years old and less than 120 years old to be considered for harvest. A time constraint was added to the model to require 10 years between stand entries. Up to $3 \%$ of the total MP4.1 area could be harvested during any decade. In S2, up to $5 \%$ of the area could be harvested since harvest was allowed only in one management area. While the MNF Forest Plan allows for 40\% of the area in MP4.1 management areas to be disturbed in any decade, the lower target percentages used in the LANIDS scenarios were used to restrain decadal harvest within the range of 400 to 2,000 ha, another MNF Forest Plan objective.

Within the patch cut, LANDIS-II allows for partial harvest of cohorts. For this analysis, all cohorts of sugar (Acer saccharum) and red maple (A. rubrum) were removed. For all other species identified for removal (yellow birch [Betula allegheniensis], American beech [Fagus grandifolia], basswood [Tilia spp.], black cherry, northern red oak [Quercus rubra], white ash [Fraxinus americana], and yellow-poplar [Liriodendron tulipifera]), all but the youngest cohort of any existing species on the site at the time the prescription was applied were removed. In the initial conditions, all but one forest type included more than one cohort, if only one cohort was found in a stand, no harvest occurred in that stand.

Using the VNFS habitat model (Menzel and others 2006), the national forest land within the MP4.1 area was identified as either high probability of VNFS occurrence $(>75 \%)$, moderate $(50-75 \%)$, or low (0-49\%). These categories were used as management areas (MA) for the application of the patch cutting prescription. Management area one included stands with low to moderate probability of VNFS occurrence and MA two included stands with high probability of VNFS occurrence. Stands could not be split between MAs in LANDIS-II, therefore if part of a stand was considered to have a high probability of VNFS habitat from the model, the entire stand was assigned to MA 2.

Most of the parameters discussed here were varied in exploratory versions of the prescription to determine a workable final model. Early model runs did not include a maximum age limit for stands to be harvested. Model output without this constraint showed harvest 
through the oldest age classes, which was determined to be counter to the over-all goal of the Forest Plan management prescription emphasis on increasing the area in older age classes. Both one-half ha and 1 ha patch openings were modeled over 100 years. Patch openings of one-half ha did not result in discernable changes in the overall age class structure of the landscape. In order to determine if active management will result in the desired proportion of area in the youngest age class, openings were increased to 1 ha.

The individual parameters were combined into four model scenarios: 1) harvest in both management areas (S1), 2) harvest in management area one only (low-to moderate probability of VNFS occupation, S2), 3) harvest in both management areas with the exclusion of stands with $30 \%$ or greater red spruce of 80 years or older (S3), and 4) succession only (S4).

\section{Forest Plan Goals and Constraints}

The MNF Forest Plan (USDA 2006a) outlines the desired future conditions for the area with the primary goal being a mosaic of red spruce and red spruce-hardwood forests providing habitat to meet recovery objectives for VNFS and CMS. Multi-age stand structures and late successional species compositions are desired with 3-8\% of the red spruce-dominated forest in the 1-19 year age class, 3-8\% of those forest types in the $20-39$ year age class, $5-15 \%$ in the 40 79 year age class, $5-15 \%$ in the $80-119$ year class, and 60 to $80 \%$ of the red spruce and red spruce-hardwood forest older than 120 years (Table 4.1; USDA 2006a). In these areas, the Forest Plan allows for uneven-aged management to create the desired multi-aged conditions. Group selection is allowed by the Forest Plan with the guideline that openings be limited to two acres or less. The patch cutting harvests modeled here are 1 ha, about 2.47 acres, exceeding this guideline.

To meet the desired future condition for MP4.1 lands, the MNF Forest Plan allows approximately 400 to 2,000 ha of active stand manipulation over each 10 year period (USDA 2006a). I attempted to reach the upper limit of the allowed management in each decade of the simulation and assumed that stand management would continue beyond the expected 10-15 year life-span of the Forest Plan. 


\section{LANDIS-II Output}

To determine if the LANDIS-II model projections resulted in the desired age class distribution, modeled species dominance was classified into forest types and spatially associated with modeled average cell age. The LANDIS-II extension Reclass Output version 1.1 was used to group the individual species model outputs into forest types described in the MNF Forest Plan desired future conditions. Forest types created from the model output were: red spruce, red spruce-northern hardwoods, northern hardwoods, mixed cove, and mixed oak. The Reclass Output extension uses the species and age cohort information for each cell to calculate a dominance value using the maximum age for each species on the site and the species longevity (one of the basic parameters for the larger model). The forest types are described by the modeler in a species list. A cell is assigned the forest type corresponding to the highest total dominance value calculated.

The LANDIS-II extension Age Cohort Statistics version 1.0 was used to organize the species and cohort output. Average age was calculated for each cell for red spruce, sugar maple, American beech, and yellow birch species individually. The average age for each cell for all species found on that cell was also calculated by this extension.

To determine the extent that Forest Plan goals were reached, first the output grids for average cell age and reclassified forest type were converted to shapefiles and clipped to the boundaries of the MP4.1 prescription area. Then the average age of each cell was spatially associated with the calculated forest types through the identity function in ArcMap 9.3.1 (ESRI 2009). These forest type-age combinations were then summarized by age classes used in the MNF Forest Plan; 1-19, 20-39, 40-79, 80-119, and 120 year and older. This summarization was made for the harvested model runs and the succession-only runs with results averaged after summarization. The resulting age class distributions were compared for the percent of area in red spruce and red spruce-northern hardwood forest types. For the harvest model runs, output from the Base Harvest extension v1.3 was used to summarize the area harvested by decade, species removed by harvesting, and age of stand at harvest.

To compare the structural complexity of the landscapes resulting from 100 years of application of the model scenarios, the neighborhood statistic focal variety was calculated in ArcMap 9.3.1 (ESRI 2009) using a moving window of 3 by 3 cells. This calculation tallies the number of unique values of the cells within the nine-cell neighborhood returning that value for 
the center cell. The previously created age classes and forest type shapefiles at year 100 for each model run were used for this analysis. For calculation of focal variety at year 100 for each scenario, each combination of a forest type and an age class was given a code and a 50 by $50 \mathrm{~m}$ raster created to represent these 25 combinations on which the variety score was calculated. The scores from the three runs of each scenario were averaged. Raw neighborhood variety scores ranged from one to nine as there are nine cells in the neighborhood; averaged variety scores ranged from one to eight. These scores were grouped as low variety (one and two), low to medium variety (three and four), medium to high variety (four and five), and high variety (seven and eight).

\section{Determination of Sample Size}

An analysis was made on preliminary results to determine the number of scenario runs to use to reach a desired confidence that the run means were not statistically significantly different $(\alpha=0.05)$. Once the basic parameters had been determined and set in the model, three model runs were made for all four scenarios and average cell age was spatially associated with the reclassified forest types. These forest type and age combinations were further summarized to the Forest Plan age classes by percent of the forest type total. The means and standard deviations of area in the youngest age class (1-19 years) at age 10 of the three runs were entered in SAS Power and Sample Size 3.1 (SAS 2007) with nominal power of 0.8 and 0.9, and a desired $\alpha$ of 0.05 . The linear model (PROC GLMPOWER) was solved for sample size through one-sample t-test analysis.

\section{Results}

The power analysis of the mean harvest runs determined that three replications of the model were sufficient to achieve a power of 0.9 at $\alpha=0.05$. Results reported here are the averages of three model runs for each scenario. All harvest scenarios include the same 1 ha patch cutting prescription where up to $30 \%$ of the total stand area was harvested by partial harvest.

To assess the validity of the reclassified forest types, forest types created in time 0 through the LANDIS-II Reclass Extension were compared to the initial conditions used to initialize the model. The forest types of the initial stands were tallied by the reclassified forest 
types and area totals compared. The northern hardwoods forest type was reclassified within $0.8 \%$ of initial conditions, red spruce forests were within $0.05 \%$, red spruce-northern hardwood forests were within $0.05 \%$, mixed cove forests were within $2.3 \%$, and mixed cove forests were within $5.5 \%$. This was considered adequate for continuing the reclassification of forest type for the other modeled decades.

The model outputs were summarized by forest type and mean cell age (all species present) and by age classes used in the MNF Forest Plan to compare the results for the three harvest scenarios and succession only. Red spruce and red spruce-northern hardwood forest types were combined and only those forest types are reported here. When compared by age class and over time, the harvest scenarios differ from succession for the first three decades of the model for the youngest age class (Figure 4.2). All scenarios resulted in the 1-19 year age class below the MNF Forest Plan goal of 3-8\%. Scenario 3 was the closest to the goal at about $2 \%$ in the third decade of the model. In all scenarios this age class declined in abundance over time going below $0.5 \%$ around 80 years. In year 20, all three harvest scenarios resulted in area in the 1-19 year age class different than the succession only model. By year 40, S2 differed from succession; after year 60, two harvest models (S1 and S2) created the same percentage of this age class and were not different than succession only. At year 40, the area in the youngest age class for S3 was slightly greater than succession only and S1 and S2.

All four scenarios created the same proportion of the 20-39 year age class in the first two decades of the models (Figure 4.3). By the third decade, the three harvest scenarios resulted in greater area in this age class compared to succession only. All scenarios showed a rapid decline in area in this age class for the first three decades. After the third decade, S1, S2, and S4 deviated from S3. Scenario 3 meets or slightly exceed the lower limit (3\%) of the MNF Forest Plan goal for this age class in decades 40 through 70.

The greatest differences between the harvest scenarios and succession-only were found in the creation of the 40-79 year age class (Figure 4.4). The third decade is again an inflection point, with $S 1$ and $S 3$ remaining well above $S 2$ and succession-only in years 30 through 90 . At the end of the model period, S1, S2, and S4 meet the MNF Forest Plan goal for this age class (5$15 \%$ ). The succession-only scenario reached $15 \%$ of the area in this age class in decade three, $\mathrm{S} 2$ reached this goal in decade eight, and $\mathrm{S} 1$ at decade nine. 
For the 80-119 year age class, the four scenarios started to differ in percent of area at year 20 with an inflection point at year 30 (Figure 4.5). During decades three through nine, S1 and S3 resulted in nearly $40 \%$ of the area of red spruce forest types in this age class. During this same time-frame, where harvest is restricted to one MA (S2) or not allowed (S4), 40 to $50 \%$ of the area was maintained in this age class. All scenarios resulted in a landscape with much higher percentages of this age class than the MNF Forest Plan goal of 5-15\%.

The oldest age class was protected from harvest as the maximum age of harvest was limited to 120 years in all harvest scenarios. As younger age classes were created through succession, differences in the four scenarios for the 120 and greater age class do occur starting at decade eight (Figure 4.6). For the last two decades of the model, the succession-only scenario resulted in greater amounts of area in this age class as compared to the harvest scenarios. The MNF Forest Plan goal for these forest types in this age class is 60-80\%; at the end of the model period, succession-only resulted in about $59 \%$ of the area in these forest types in this age class.

Portions of the landscapes resulting from the four scenarios at year 30 and 100 show the landscape patterns resulting from the four scenarios (Figure 4.7 - 4.10). When harvests are allowed in both management areas the resulting landscapes are similar compared to the scenario where harvest is allowed only in areas of low to moderate VNFS probability.

The three harvest scenarios differed in the amount of area harvested by decade (Figure 4.11). Scenario 3 had the fewest restrictions for harvesting and as a result had the greatest area harvested over the modeled time frame. All scenarios show a drop in area harvested between year 40 and 50 and again between year 90 and 100. At the end of the model period, very few stands meet the requirements for harvest in S2.

The three harvest scenarios also differed slightly in species removals (Figures 4.12 4.14) and ages of stands harvested (Figures 4.15 - 4.17). Initial harvests in the first decade were nearly the same for all scenarios with $38 \%$ of the cohorts removed being sugar maple, 29 - 31\% yellow birch, and about 31-33\% American beech. For S1 and S2, no black cherry, white ash, or yellow-poplar cohorts were removed (Figures 4.12 and 4.13). In S3, black cherry and white ash are removed but make up less than $0.01 \%$ of the harvested cohorts. Yellow-poplar is removed in S3 starting in year 30 reaching a high of $15 \%$ of the harvested cells in year 50 (Figure 4.14).

Red maple made up between 18 and $24 \%$ of the harvest at its highest for all three scenarios. The removal of sugar maple was similar for S1 and S2 with sugar maple making up 
38 to $51 \%$ until time 100 when it dropped to either $23 \%$ (S1) or $25 \%$ (S2) of harvest. In contrast, sugar maple removal was much more variable for S3, with its removal making up between 8 to $38 \%$ of the harvest with the least amount of sugar maple removed in year 50. Northern red oak was not removed in any substantial amount until year 100 for S1 and S2 and only made up 3\% (S1) or 5\% (S2) of the total removals. In contrast, northern red oak was removed starting in year 30 in S3 and made up between 6 to $15 \%$ of the harvest. Both S1 and S2 included a requirement that harvests occur in stands with existing red spruce while S3 did not but excluded some red spruce stands. These restrictions served to focus harvest in S1 and S2 on northern hardwood stands, with likely greater potential to support red spruce, more so than in S3.

As with species removed through harvest, the stand ages harvested were similar for S1 and S2 particularly for years 50-90 (Figures 4.15 and 4.16). These five decades differed greatly compared to S3 for the same time period. For S3 after year 20, most of the harvested stands were 100-119 years old (Figure 4.17). All harvest scenarios constrained harvests to stands between 50 and 120 years old. Stands $50-59$ years old made up little of the harvested stands for S3 in any decade, and made up nearly $50 \%$ of the harvest in year 20 for S2. At year 100, very little area is harvested in S2. For S1, younger stands made up about $35 \%$ of the harvest in year 20 and about $25 \%$ at year 100 . The oldest stands allowed for harvest made up nearly $80 \%$ of the harvested area in year 10 for S3, and were not harvested at all in decades two and three. All harvest scenarios had the same maximum and minimum age requirements for harvest, differences in harvested stand ages are a result of differences in species constraints.

With the allowance for stand entry every 10 years, most stands were entered more than once. In S1, 51\% of the stands selected for harvest were entered more than once. In S2, 62\% of stands selected were entered more than once. In S3, approximately $72 \%$ of the stands were entered more than once. Although the patch cuts were not complete removals and only $30 \%$ of the stand was harvested, these multiple entries may pose a problem in reaching the MNF Forest Plan objective of older-aged stands.

None of the scenarios, including succession only, resulted in substantial increases in the overall area covered by red spruce-dominated forest in the model period. All scenarios started with about $36 \%$ of the un-buffered study area in red spruce or red spruce-northern hardwood forests and end at year 100 with about $38 \%$ (S1, S2, and S4) or 39\% (S3) of the area in these forest types (Table 4.8). While there is no significant difference between scenarios, there is a 
trend for the red spruce-dominated forests to expand as this long-lived, shade tolerant species continues to grow in the study area.

The estimate of structural complexity through the calculation of variety scores did uncover differences in between scenarios at the end of the model period (Figure 4.18). Variety scores were from the calculation of the number of unique forest type-age class combinations in a nine-cell neighborhood. The succession only scenario resulted in a landscape with the greatest area in low variety cells at about $82 \%$. Scenario 3 resulted in a landscape with the least amount of area in low variety cells (about $69 \%$ ). Scenarios 1 and 2 were similar in variety class scores. All scenarios resulted in landscapes with less than $0.5 \%$ of the cells with high variety scores and $\mathrm{S} 3$ resulted in the highest amount in medium-high variety at $3 \%$ of the area.

\section{Discussion}

Forest Plan goals for the 40-79 year age class were met by all scenarios at the end of the model period. Under succession only, the MNF Forest Plan goal for the oldest age class is nearly met by the end of the model period. Limited progress was made in meeting MNF Forest Plan goals for the youngest age class in red spruce-dominated forest types based on the patch harvesting applied in the harvest scenarios (S1, S2, and S3). As stated in the MNF Forest Plan, with continued succession and uneven-aged management, these largely even-aged stands (resulting from past management) will eventually convert to all-age conditions and the ages of stands in the oldest age classes represent time since the last stand-replacing event and not individual tree ages. Red spruce, sugar maple, and American beech are all long-lived and shade tolerant. As such, the assignment of age classes by taking the average cell age may misrepresent actual stand conditions. No stand-replacing events, such as hurricanes, were modeled in either the harvest or succession scenarios. In these high-elevation forests, gap dynamics is the main natural disturbance regime (White and others 1985; Rentch and others 2010), so no large-scale wind events or disease outbreaks were included in the model. Using biomass succession instead of age-only succession in LANDIS-II should model the mortality and growth of trees under competition similar to gap-phase dynamics (Scheller and Mlandenoff 2004).

At the end of the model period (100 years) the stands resulting from patch cutting and succession only were uneven-aged. The silvicultural goal of a desired, sustainable diameter distribution could be appropriate at the stand level as a measure of progress toward uneven-aged 
conditions in the stand. Given the longevities and shade tolerances of the principle species in the study area, it is not surprising that limited partial harvesting in relatively small patch cuttings over 100 years did not show dramatic differences over succession only.

Projected climate changes were not included in this model. Current climate models could be used to create new average monthly temperatures and precipitation amounts. These climate estimates would then be used to calculate new species establishment probabilities (Scheller and Mladenoff 2005; Gustafson and others 2007). The climate variables used to estimate the establishment probabilities in the model came from local sources and span a few decades. Using modeled climate data would have the added complication of the scale at which such data are generally applicable and another set of modeling assumptions.

Modeling potential habitat for red spruce based on current habitat and modeled future climate has predicted that potential red spruce abundance will be reduced by 10 to $19 \%$ relative to current habitat across the species' range, and suitable habitat lost completely in West Virginia by 2100 (Prasad and others 2007-ongoing). A recent model of future red spruce distribution in West Virginia including two levels of climate change resulted in no suitable red spruce habitat in 2080 under an aggressive climate change scenario (Beane 2010). Also with this model, by 2020 suitable red spruce habitat across West Virginia declined by about $79 \%$ with an aggressive climate change scenario and 55\% under a conservative climate change scenario (Beane 2010). However, Potter and others (2010) found little difference in available red spruce habitat in the southern and central Appalachians due to climate change. Red spruce is a specialist in terms of habitat requirements making it vulnerable to climate change. The LANDIS-II model presented here represents change under a stable climate with an interest in determining change over time from stand-level forest management.

The extent of existing understory red spruce was difficult to map for the initial conditions of this model. Based on observations of some of the MP4.1 areas, it was assumed for the initial conditions that young and old red spruce forests contained younger or understory red spruce cohorts. The MNF plot data was queried for remarks that included mention of understory red spruce and those stands were given a young cohort in the initial conditions. There are likely more stands with red spruce regeneration in reality than modeled here and suppressed understory red spruce may not equate to a young cohort as used in the model. Remote sensing mapping of current red spruce is underway in the study area and is being field-checked for accuracy. This 
effort and plot-based data sources could be used to create a regression model for predicting understory red spruce in other areas that could then be used in this LANDIS-II model.

While impact on age class across landscape may not be great, stand-level composition and structural changes may occur and benefit red spruce. At the stand level, simulations have found that crown thinning delayed spruce movement to the canopy, while low thinning increased the importance of red spruce (Schuler and others 2002). These findings were reinforced by 100year growth simulations on second-growth northern hardwood stands in West Virginia with understory red spruce using red spruce release and no-release scenarios (Rentch and others 2007). The authors found that thinning (from above as stands are dominated by hardwoods) to $50 \%$ of the original basal area could double red spruce basal area in 20 to 40 years. Since the LANDIS-II model is cohort-based, stand basal area is not known. In the LANDIS-II scenarios presented here, patch cuttings were intended to act as both release for any existing red spruce and also as potential sites for new red spruce regeneration.

At 10 years between stand entries, more than half of the stands initially selected for harvest were entered more than once. With 30 years between entries, $81 \%$ of the stands had multiple entries. At 40 years between stand entries, the model fairly rapidly met with too many constraints, resulting in very few stands available for harvest at model decade 50 . The percent of the management area harvested could have been reduced to create a more even level of harvest through the decades.

There are many opportunities to use the basic model to conduct "what if" scenarios making modifications to parameters such as age of stand entry and time between stand entries or developing harvest scenarios other than patch cutting. While this study focused on the MNF Forest Plan, many other restoration or management ideas could be modeled. Small openings could be created every year at 1\% (Seymour 2005) or 1.4\% (Rentch and others 2010) of area in red spruce-dominated forests to mimic gap-phase dynamics.

In second-growth red spruce-northern hardwood forests, canopy gaps are largely small, with a mean age of about 13 years, and a canopy turnover rate of about $1.4 \%$ per year (Rentch and others 2010). This mortality should be captured by the biomass succession model used in the LANDIS-II scenarios. Analysis of the dead biomass outputs of the succession scenario could be made to determine if this canopy mortality is occurring as a result of the biomass input 
parameters. Changes to the morality curve parameter to better mimic mortality due to competition may be needed.

The maximum biomass and annual net primary productivity estimates used in this study came from an analysis of Forest Inventory and Analysis plots combined with species-specific biomass regression equations and summarized by forest type (Jenkins and others 2001). LANDIS-II uses maximum biomass and maximum net annual primary productivity by species and the Jenkins and others (2001) values by forest type were assigned to the individual species making up those forest types; each species in the forest type received the same value as the others in the forest type. Greater refinement of the biomass parameters by individual species is needed.

\section{Conclusions}

The LANDIS-II model proved useful in determining differences in harvest scenarios with differing restrictions. Specifically, harvesting stands from one or both management areas under the same stand ranking criteria (S1 and S2) resulted in little difference compared to the same harvest type but under differing stand selection criteria (S3). In this study, only one type of harvesting was used to compare other outcomes of harvest; however the model is not limited to patch cutting.

With the patch cutting modeled here, some progress is made toward Forest Plan goals and the impact of attaining one goal on another can be determined. To make substantial progress toward reaching the goal for the youngest age class through harvesting creates a lag in reaching the goal for the oldest age-class. For example, the scenario with the most harvest (S3) provides the same amount of area in the oldest age class for the first 70 years of the model before lagging behind the succession only scenario.

Harvests were conducted every decade and stands were allowed to be entered every decade in the scenarios assessed here. The results of area harvested by decade show that this may not be desirable if an even area of harvest every decade is a goal. Multiple stand entries may be desired if harvests require the investment of a road system, however some stands were entered eight times in the 100 year period.

The desired age class distribution of red spruce and red spruce-northern hardwood forest types was chosen to compare to model outputs and as a measure of success in restoring these 
forest types. Other output from the model may be more useful in describing success of restoration efforts at the landscape level. Results of the modeled scenarios include maximum, minimum, and average age for each species separately. An analysis of the results for just red spruce may prove useful in restoration efforts. Given that stands in MP4.1 are expected to trend toward multi-aged conditions, stand-level measures of success may be more useful.

The model for MP4.1 lands as parameterized here can continue to be a valuable tool for testing and discovering the landscape-level results of forest management. The tool is flexible in time and the variety of disturbances to be modeled. This area-based, stochastic model does not make decisions for the land manager but can inform decisions through long-term simulations of events and interactions. 


\section{Literature Cited}

Beane, N.R. 2010. Using environmental and site-specific variables to model current and future distribution of red spruce (Picea rubens Sarg.) forest habitat in West Virginia. Dissertation, West Virginia University, Morgantown, WV.

Botkin, D.B. 1993. Forest dynamics: an ecological model. Oxford University Press, Inc., New York, New York.

Burns, R.M.; Honkala, B.H. 1990. Silvics of North America: 1. Conifers; 2. Hardwoods. Agriculture Handbook 654. U.S. Department of Agriculture, Forest Service, Washington, DC. 877 p.

Brown, P.M. 1996. OLDLIST: A database of maximum tree ages. In: Dean, J.S; Meko, D.M; Swetnam, T.W., eds. Proceedings of International Conference on tree rings, environment, and humanity: Relationships and processes. Radiocarbon: 727-731.

Cleland, D.T.; Freeouf, J.A.; Keys, Jr., J.E.; Nowacki, G.J.; Carpenter, C.A.; McNab, W.H. 2007. Ecological subregions: sections and subsections of the conterminous United States. [1:3,500,000] CD-ROM. Gen. Tech. Rep. WO-76. Washington, D.C.: U.S. Department of Agriculture, Forest Service.

ESRI. 2009. ArcGIS 9.31. Redlands, CA: Environmental Systems Research Institute.

Fahey, T.J.; Reiners, W.A. Fire in the forests of Maine and New Hampshire. Bulletin of the Torrey Botanical Club 108(3): 362-373.

Fowells, H.A. 1965. Silvics of forest trees of the United States. USDA Forest Service, Agriculture Handbook 271.

Gustafson, E.J.; Sturtevant, B.R.; Shvidenko, A.Z.; Scheller, R.M. 2007. Supporting landscape ecological decisions using the LANDIS-II forest dynamics simulator. IUFRO Conference in Forest landscape Restoration, Soul Korea: 73-75.

Hart, A.C. 1959. Silvical characteristics of red spruce (Picea rubens). USDA Forest Service, Station Paper NE-124, Northeastern Forest Experiment Station.

Harmon, M.E. 1981. Fire history of the Great Smoky Mountains National Park - 1940 to 1979. NPS-SER Research/Resources Management Report No. 46, Uplands Field Research Laboratory, Great Smoky Mountains National Park, USDI National Park Service.

He, H.S.; Mladenoff, D.J. 1999. The effects of seed dispersal on the simulation of long-term forest landscape change. Ecosystems 2: 308-319. 
He, H.S.; Li, W.; Sturtevant, B.R.; Yang, J.; Shang, B.Z.; Gustafson, E.J.; Mladenoff, D.J. 2005. LANDIS 4.0 users guide. LANDIS: a spatially explicit model of forest landscape disturbance, management, and succession. General Technical Report NC-263. St. Paul, MN: U.S. Department of Agriculture, Forest Service, North Central Research Station.

Hicks, R.R., Jr. 1998. Ecology and management of central hardwood forests. John Wiley and Sons, Inc.

Hopkins, A.D. 1899. Report on investigations to determine the cause of unhealthy conditions of the spruce and pine from 1880-1893. West Virginia Exp. Sta. Bulletin 56.

Hornbeck, J.W.; Kochenderfer, J.N. 1998. Growth trends and management implications for West Virginia's red spruce forests. Northern Journal of Applied Forestry 15(4): 197-202.

Jenkins, J.C.; Birdsey, R.A.; Pan, Y. 2001. Biomass and NPP estimation for the mid-Atlantic region (USA) using plot-level forest inventory data. Ecological Applications 11(4): 1174-1193.

Kitamura, K.; Morita, T.; Kudo, H.; O-Neil, J.; Utech, F.H.; Whighams, D.F.; Kawano, S. 2003. Demographic genetics of the American beech (Fagus grandifolia Ehrh.) III. genetic substructuring of coastal plain population in Maryland. Plant Species Biology: 18: 13-33.

Korstian, C.F. 1937. Perpetuation of spruce on cut-over and burned lands in the higher southern Appalachian Mountains. Ecological Monographs 7(1):125-167.

Larson, M.A.; Thompson, F.R.; Millspaugh, J.J.; Dijak, W.D.; Shifley, S.R. 2004. Linking population viability, habitat suitability, and landscape simulation models for conservation planning. Ecological Modelling 180: 103-118.

Lewis, R.L. 1998. Transforming the Appalachian countryside: Railroads, deforestation, and social change in West Virginia, 1880-1920. The University of North Carolina Press, Chapel Hill, NC.

Lorimer, C.G.; Dahir, S.E.; Nordheim, E.V. 2001. Tree mortality rates and longevity in mature and old-growth hemlock-hardwood forests. Journal of Ecology 89: 960-971.

Menzel, J.M.; Ford, W.M.; Edwards, J.W.; Ceperley, L.J. 2006. A habitat model for the Virginia northern flying squirrel (Glaucomys sabrinus fuscus) in the central Appalachian Mountains. USDA Forest Service, Res. Pap. NE-729.

Mladenoff, D.J. 2004. LANDIS and forest landscape models. Ecological Modelling 180: 7-19.

Northeastern Ecosystem Research Cooperative foliar chemistry database (NERC). 2011. USDA Forest Service Northeastern Research Station and University of New Hampshire Complex Systems Research Center. [access date 02/23/2011] (http://www.folchem.sr.unh.edu). 
NOAA. 2009. National climatic data center. [access date 10/29/2009] (http://www.ncdc.noaa.gov/oa/ncdc.html).

Nesom, G. 2006. Plant guide basswood. USDA Natural Resources Conservation Service. http://plants.usda.gov.

Pastor, J.; Post, W.M. 1985. Development of a linked forest productivity-soil process model, Oak Ridge National Laboratory, Environmental Sciences Division Publication No. 2455.

Pielke, R.A. 1981. The distribution of spruce in west-central Virginia before lumbering. Castanea 46: 201-216.

Potter, K.M; Hargrove, W.W.; Koch, F.H. 2010. Predicting climate change extirpation risk for central and southern Appalachian forest tree species. In: Rentch, J.S.; Schuler, T.M., eds. Proceedings from the conference on the ecology and management of high-elevation forests in the central and southern Appalachian Mountains. 2009 May 14-15; Slatyfork, WV. General Technical Report NRS-P-64. Newtown Square, PA: USDA, Forest Service, Northern Research Station.

Prasad, A. M., L. R. Iverson., S. Matthews., M. Peters. 2007-ongoing. A Climate Change Atlas for 134 Forest Tree Species of the Eastern United States [database]. http://www.nrs.fs.fed.us/atlas/tree, Northern Research Station, USDA Forest Service, Delaware, Ohio.

Rentch, J.S.; Schuler, T.M.; Ford, W.M.; Nowacki, G.J. 2007. Red spruce stand dynamics, simulations, and restoration opportunities in the central Appalachians. Restoration Ecology 15(3): 440-452.

Rentch, J.S.; Schuler, T.M.; Nowacki, G.J.; Beane, N.R.; Ford, W.M. 2010. Canopy gap dynamics of second-growth red spruce-northern hardwood stands in West Virginia. Forest Ecology and Management 260: 1921-1929.

SAS. 2007. SAS power and sample size 3.1. SAS Institute, Inc, Cary, North Carolina, USA.

Saxton, K.E.; Rawls, W.J. 2006. Soil water characteristic estimates by texture and organic matter for hydrologic solutions. Soil Science Society of America Journal 70: 1569-1578.

Scheller, R.M.; Mladenoff, D.J. 2004. A forest growth and biomass module for a landscape simulation model, LANDIS: design, validation, and application. Ecological Modelling 180: 211-229.

Scheller, R.M.; Mladenoff, D.J. 2005. A spatially interactive simulation of climate change, harvesting, wind, and tree species migration and projected changes to forest composition and biomass in northern Wisconsin, USA. Global Change Biology 11: 307-321. 
Scheller, R.M.; Mladenoff, D.J.; Crow, T.R.; Sickley, T.A. 2005. Simulating the effects of fire reintroduction versus continued fire absence on forest composition and landscape structure in the Boundary Waters Canoe Area, northern Minnesota, USA. Ecosystems 8: 396-411.

Scheller, R.M.; Domingo, J.B.; Sturtevant, B.R.; Williams, J.S.; Rudy, A.; Gustafson, E.J.; Mladenoff, D.J. 2007. Design, development, and application of LANDIS-II, a spatial landscape simulation model with flexible temporal and spatial resolution. Ecological Modelling 201: 409-419.

Schuler, T.M.; Ford, W.M.; Collins, R.J. 2002. Successional dynamics and restoration implications of a montane coniferous forest in the central Appalachians, USA. Natural Areas Journal 22(2): 88-98.

Seymour, R.S. 2005. Integrating natural disturbance parameters into conventional silvicultural systems: experience from the Acadian forest of Northeastern North America. In Peterson, C. E.; Maguire, D.A., eds. 2005. Balancing ecosystem values: innovative experiments for sustainable forestry. USDA Forest Service, General Technical Report PNW-GTR-635: 41-46.

Shifley, S.R.; Thompson, F.R., III; Larsen, D.R.; Dijak, W.D. 2000. Modeling forest landscape change in the Missouri Ozarks under alternative management practices. Computers and Electronics in Agriculture 27: 7-24.

Shifley, S.R.; Thompson, F.R.; Dijak, W.D.; Larson, M.A.; Millspaugh, J.J. 2006. Simulated effects of forest management alternatives on landscape structure and habitat suitability in the midwestern United States. Forest Ecology and Management 229: 361-377.

Stephenson, S.L. 1993. Upland forests of West Virginia. McClain Printing Co, Parsons, WV.

Tyrell, L.E.; Crow, T.R. 1994. Dynamics of dead wood in old-growth hemlock-hardwood forests of northern Wisconsin and northern Michigan. Canadian Journal of Forest Research 24: 1672-1683.

USDA Forest Service. 2006a. Monongahela National Forest, land and resource management plan. USDA Forest Service, Monongahela National Forest, Elkins, WV.

USDA Forest Service. 2006b. Monongahela National Forest, final environmental impact statement for forest plan revision. USDA Forest Service, Monongahela National Forest, Elkins, WV.

USDA Natural Resources Conservation Service. 2002. Plant fact sheet red spruce. USDA NRCS. http://plants.usda.gov.

Ward, B.C.; Mladenoff, D.J.; Scheller, R.M. 2005. Simulating landscape-level effects of constraints to public forest regeneration harvests due to adjacent residential development 
in northern Wisconsin. Forest Science 51(6): 616-632.

Westveld, M. 1 953. Ecology and silviculture of the spruce-fir forests of eastern North America. Journal of Forestry 51:422-430.

White, P.S.; MacKenzie, M.D.; Busing, R.T. 1985. Natural disturbance and gap phase dynamics in southern Appalachian spruce-fir forests. Canadian Journal of Forest Research 15: 223-240. 
Table 4.1 - Existing age class distribution for red spruce and red spruce-northern hardwood forest types for stands assigned to the 4.1 Management Prescription and the desired future conditions from the Monongahela National Forest, Forest Plan. Distributions are expressed as a percentage of area in that age class relative to the total area in these forest types.

\begin{tabular}{l|cc}
\hline Age class & Existing conditions (\%) & Desired future conditions (\%) \\
\hline $\mathbf{1 - 1 9}$ & 0.2 & $3-8$ \\
$\mathbf{2 0 - 3 9}$ & 12.8 & $3-8$ \\
$\mathbf{4 0 - 7 9}$ & 29.2 & $5-15$ \\
$\mathbf{8 0 - 1 1 9}$ & 48.8 & $5-15$ \\
$\mathbf{1 2 0 +}$ & 9.0 & $60-80$ \\
\hline
\end{tabular}


Table 4.2. - Initial community information based on Monongahela National Forest stand data used to initialize the model. Stands with no information make up 5.5 percent of the study area (39.5 percent of the model area).

\begin{tabular}{|c|c|c|}
\hline Community & Ages & $\begin{array}{c}\text { Percent } \\
\text { study area } \\
\text { (model area) }\end{array}$ \\
\hline Young beech & 20,40 & $0.03(0.02)$ \\
\hline Mature beech & $60-90$ & $0.2(0.1)$ \\
\hline Old beech & $100-140$ & $0.6(0.1)$ \\
\hline Young to mature birch & $20-60$ & $0.3(0.1)$ \\
\hline Old birch & $70-110,130$ & $2.1(1.1)$ \\
\hline Young black cherry-white ash/yellow-poplar & $10-20$ & $0.2(0.1)$ \\
\hline Mature black cherry-white ash/yellow-poplar & $30-60$ & $0.2(0.1)$ \\
\hline Old black cherry-white ash/yellow-poplar & $70-120,150$ & $4.2(3.0)$ \\
\hline Mature hemlock & $70-100$ & $0.3(0.3)$ \\
\hline Old hemlock & $110-120,150,170$ & $0.1(0.1)$ \\
\hline Young northern red oak & 20 & $0.0(0.02)$ \\
\hline Mature northern red oak & $80-120,150,200$ & $0.1(0.7)$ \\
\hline Mature red maple & $40-80$ & $0.5(0.2)$ \\
\hline Old red maple & $90-110,180$ & $0.8(0.4)$ \\
\hline Young sugar maple-beech-yellow birch/red spruce & $10-40$ & $1.9(0.4)$ \\
\hline Mature sugar maple-beech-yellow birch/red spruce & $50-90$ & $12.1(4.7)$ \\
\hline Old sugar maple-beech-yellow birch/red spruce & $140-200$ all; $10-20,320$ red spruce & $9.6(3.3)$ \\
\hline Young red spruce & $10-40$ & $2.7(0.6)$ \\
\hline Mature red spruce & $70-120$ & 7.8 (3.3) \\
\hline Old red spruce & $10-20,130-190$ & $0.9(0.2)$ \\
\hline Young sugar maple & $10-40$ & $0.03(0.03)$ \\
\hline Mature sugar maple & $20,50-100$ & $0.1(0.2)$ \\
\hline Old sugar maple & $20,110-120$ & $0.02(0.1)$ \\
\hline Mature sugar maple-basswood & 70-100 both; 20 sugar maple & $0.1(0.2)$ \\
\hline Old sugar maple-basswood & $120-130$ both; 20 sugar maple & $0.04(0.04)$ \\
\hline Young sugar maple-beech-yellow birch & $10-40$ & $1.0(1.3)$ \\
\hline Mature sugar maple-beech-yellow birch & 50-120 all; 20 sugar maple and beech & $15.7(28.2)$ \\
\hline Old sugar maple-beech-yellow birch & 130-160 all; 20 sugar maple and beech & $0.2(0.5)$ \\
\hline Young mixed hardwoods' & $10-20$ & $0.5(0.1)$ \\
\hline Mature mixed hardwoods & $30-80$ & $8.6(1.9)$ \\
\hline Old mixed hardwoods & $\begin{array}{l}90-150 \text { all; } 20 \text { red maple and beech; } \\
240 \text { yellow-poplar and northern red oak }\end{array}$ & $22.5(5.1)$ \\
\hline Young mixed oak ${ }^{2}$ & $10-20$ & $0.0(0.1)$ \\
\hline Mature mixed oak & 30-70 all oaks; 10 red maple & $0.0(0.1)$ \\
\hline Old mixed oaks & $70,80,100 ;$ and 10 red maple & $0.1(2.9)$ \\
\hline Young yellow-poplar/white oak/N. red oak & $10-20$ & $0.0(0.0)$ \\
\hline Mature yellow-poplar/white oak/N. red oak & $30-80$ & $0.0(0.1)$ \\
\hline Old yellow-poplar/white oak/N. red oak & $90-110$ & $0.3(0.6)$ \\
\hline Young hemlock & $10-60$ & $0.0(0.01)$ \\
\hline Young red maple & $10-30$ & $0.0(0.02)$ \\
\hline Young sugar maple-basswood & $10-60$ & $0.0(0.03)$ \\
\hline $\begin{array}{l}\text { Mature sugar maple-beech-yellow birch/red spruce } \\
\text { with red spruce regeneration }\end{array}$ & 50-90 for all; $10-20$ red spruce & $0.2(0.1)$ \\
\hline $\begin{array}{l}\text { Old sugar maple-beech-yellow birch/red spruce } \\
\text { with red spruce regeneration }\end{array}$ & $140-190$ for all; $10-20$ for red spruce & $0.6(0.1)$ \\
\hline
\end{tabular}


Table 4.3. - Life history characteristics by species used as input for all LANDIS-II scenarios.

\begin{tabular}{|c|c|c|c|c|c|c|c|c|}
\hline Species & Longevity & $\begin{array}{c}\text { Sexual } \\
\text { Maturity }\end{array}$ & $\begin{array}{l}\text { Shade } \\
\text { tolerance }\end{array}$ & $\begin{array}{l}\text { Effective } \\
\text { seed } \\
\text { dispersal } \\
\text { distance } \\
(m)\end{array}$ & $\begin{array}{c}\text { Max. } \\
\text { seed } \\
\text { dispersal } \\
\text { distance } \\
(m)\end{array}$ & $\begin{array}{l}\text { Vegetative } \\
\text { reproductive } \\
\text { probability }\end{array}$ & $\begin{array}{l}\text { Min. } \\
\text { sprout } \\
\text { age }\end{array}$ & $\begin{array}{l}\text { Max. } \\
\text { sprout } \\
\text { age }\end{array}$ \\
\hline Red maple & $180^{1}$ & $20^{1}$ & $4^{1}$ & $100^{4}$ & $200^{4}$ & $0.8^{1,5}$ & 0 & $150^{4,5}$ \\
\hline $\begin{array}{l}\text { Sugar } \\
\text { maple }\end{array}$ & $300^{1}$ & $40^{1}$ & $5^{1}$ & $100^{1}$ & $200^{4}$ & $0.7^{1,5}$ & 0 & $200^{1,4}$ \\
\hline $\begin{array}{l}\text { Yellow } \\
\text { birch }\end{array}$ & $300^{1}$ & $50^{1}$ & $3^{1}$ & $100^{1}$ & $400^{1}$ & $0.1^{1}$ & 0 & $60^{1}$ \\
\hline White ash & $150^{2}$ & $30^{4}$ & $2^{1}$ & $70^{4}$ & $140^{1}$ & $0.7^{1}$ & 0 & $70^{4}$ \\
\hline Beech & $300^{1}$ & $50^{1}$ & $5^{1}$ & $3^{6}$ & $35^{6}$ & $1^{1}$ & 0 & $60^{1}$ \\
\hline $\begin{array}{l}\text { Yellow- } \\
\text { poplar }\end{array}$ & $250^{1}$ & $30^{1}$ & $1^{1}$ & $30^{1}$ & $180^{1}$ & $0.9^{1}$ & 0 & $90^{1}$ \\
\hline $\begin{array}{l}\text { Red } \\
\text { spruce }\end{array}$ & $400^{1}$ & $45^{y}$ & $4^{1}$ & 30 & $360^{y}$ & $0^{1}$ & 0 & $0^{1}$ \\
\hline Black & $200^{1}$ & $40^{1}$ & $1^{1}$ & $30^{4}$ & $3,000^{4}$ & $0.8^{1}$ & 0 & $90^{1}$ \\
\hline $\begin{array}{l}\text { Northern } \\
\text { red oak }\end{array}$ & $250^{2}$ & $50^{1}$ & $3^{1}$ & $30^{4}$ & $3,000^{4}$ & $0.9^{1}$ & 0 & $100^{1,5}$ \\
\hline White oak & $350^{2}$ & $50^{1}$ & $3^{1}$ & $30^{4}$ & $3,000^{4}$ & $0.8^{1}$ & 0 & $100^{1}$ \\
\hline Basswood & $200^{7}$ & $25^{1,7}$ & $4^{1}$ & $40^{1}$ & $80^{1}$ & $1^{7}$ & 0 & $100^{7}$ \\
\hline Hemlock & $500^{2}$ & $30^{4}$ & $5^{1}$ & $30^{4}$ & $100^{4}$ & $0^{1}$ & 0 & $0^{1}$ \\
\hline
\end{tabular}

1 - Burns and Honkala $1990 ;{ }^{2}$ - Brown 1996; ${ }^{3}$-Lorimer and others $2001 ;{ }^{4}$ - He and Mladenoff $1999 ;{ }^{5}$ personal observation; ${ }^{6}$-Kitamura and others $2003 ;{ }^{7}$-Nesom $2006 ;{ }^{8}$ - USDA NDRC $2002 ;{ }^{9}$ - Pielke 1981.

Table 4.4 - Probability of seedling establishment parameters from LINKAGES (Pastor and Post 1985) used in all LANDIS-II scenarios.

\begin{tabular}{|c|c|c|c|c|c|}
\hline \multirow{2}{*}{ Species } & \multirow{2}{*}{$\begin{array}{l}\text { Drought allowed } \\
\text { (percent of } \\
\text { growing season) }\end{array}$} & \multicolumn{2}{|c|}{$\begin{array}{c}\text { Growing degree } \\
\text { days }\end{array}$} & \multirow{2}{*}{$\begin{array}{l}\text { Minimum January } \\
\text { temp (C) }\end{array}$} & \multirow{2}{*}{$\begin{array}{c}\text { Nitrogen } \\
\text { tolerance }\end{array}$} \\
\hline & & $\max$ & $\min$ & & \\
\hline Red maple & 0.230 & 6600 & 1260 & -18 & 2 \\
\hline Sugar maple & 0.268 & 3100 & 1222 & -18 & 1 \\
\hline Yellow birch & 0.200 & 2500 & 1100 & -18 & 1 \\
\hline White ash & 0.280 & 5993 & 1398 & -12 & 1 \\
\hline Beech & 0.200 & 5537 & 1326 & -12 & 2 \\
\hline Yellow-poplar & 0.160 & 5993 & 2300 & -2 & 1 \\
\hline Red spruce & 0.237 & 2562 & 1247 & -12 & 3 \\
\hline Black cherry & 0.300 & 5993 & 2132 & -10 & 1 \\
\hline Northern red oak & 0.225 & 4571 & 1100 & -17 & 2 \\
\hline White oak & 0.330 & 5537 & 1721 & -12 & 3 \\
\hline Basswood & 0.200 & 3137 & 1400 & -17 & 1 \\
\hline Hemlock & 0.180 & 3800 & 1324 & -18 & 1 \\
\hline
\end{tabular}

Botkin 1993 
Table 4.5 - Soil and climate data by ecoregion used to calculate seedling establishment probabilities used in all LANDIS-II scenarios. Soil data were calculated from MNF soil pits, climate data are from the National Climatic Data Center (NOAA 2009).

\begin{tabular}{|c|c|c|c|c|c|c|}
\hline Ecoregion & $\begin{array}{c}\text { Field } \\
\text { Capacity } \\
\text { (cm) }\end{array}$ & $\begin{array}{c}\text { Wilting } \\
\text { Point } \\
\text { (cm) }\end{array}$ & Latitude & Longitude & $\begin{array}{c}\text { Base soil } \\
\text { nitrogen } \\
\text { (Mg/ha) }\end{array}$ & \\
\hline \multirow{3}{*}{$\begin{array}{l}\text { NHAM } \\
\text { SHAM }\end{array}$} & 26.4 & 13.1 & 38.8 & 79.9 & 4.2 & \\
\hline & 33.4 & 16.2 & 38.4 & 80.2 & 6.5 & \\
\hline & month & $\begin{array}{l}\text { Ave } \\
\text { min } \\
\text { temp. } \\
\text { (C) }\end{array}$ & $\begin{array}{c}\text { Ave } \\
\text { max } \\
\text { temp. } \\
\text { (C) }\end{array}$ & $\begin{array}{l}\text { Std. Dev. } \\
\text { Temp. }\end{array}$ & $\begin{array}{c}\text { Ave } \\
\text { precipitation } \\
\text { (cm) }\end{array}$ & $\begin{array}{c}\text { Std. Dev. } \\
\text { precipitation }\end{array}$ \\
\hline \multirow[t]{12}{*}{ NHAM } & 1 & -8.52 & 2.08 & 7.31 & 11.23 & 0.63 \\
\hline & 2 & -7.68 & 3.51 & 7.05 & 10.28 & 0.65 \\
\hline & 3 & -4.15 & 8.11 & 6.75 & 12.70 & 0.71 \\
\hline & 4 & 1.01 & 14.80 & 6.18 & 11.02 & 0.62 \\
\hline & 5 & 5.76 & 19.90 & 4.97 & 12.55 & 0.78 \\
\hline & 6 & 9.47 & 23.74 & 4.18 & 12.26 & 0.82 \\
\hline & 7 & 11.90 & 25.41 & 3.53 & 12.12 & 0.80 \\
\hline & 8 & 10.90 & 24.81 & 3.66 & 11.46 & 0.92 \\
\hline & 9 & 7.47 & 21.49 & 4.83 & 9.18 & 0.71 \\
\hline & 10 & 2.13 & 15.95 & 5.49 & 8.77 & 0.73 \\
\hline & 11 & -2.09 & 9.35 & 6.32 & 9.86 & 0.73 \\
\hline & 12 & -6.60 & 3.93 & 6.88 & 10.77 & 0.62 \\
\hline \multirow[t]{12}{*}{ SHAM } & 1 & -6.33 & 3.50 & 7.21 & 11.20 & 0.65 \\
\hline & 2 & -5.49 & 4.77 & 6.80 & 9.05 & 0.56 \\
\hline & 3 & -1.90 & 9.35 & 6.93 & 12.60 & 0.74 \\
\hline & 4 & 3.48 & 15.32 & 6.50 & 11.28 & 0.69 \\
\hline & 5 & 8.30 & 19.86 & 5.03 & 14.30 & 0.87 \\
\hline & 6 & 12.98 & 23.74 & 3.59 & 13.40 & 0.89 \\
\hline & 7 & 15.29 & 25.55 & 2.85 & 15.09 & 1.02 \\
\hline & 8 & 14.55 & 25.15 & 2.99 & 12.05 & 0.89 \\
\hline & 9 & 11.26 & 22.06 & 4.10 & 11.26 & 0.94 \\
\hline & 10 & 5.11 & 16.63 & 5.51 & 8.28 & 0.64 \\
\hline & 11 & 0.30 & 10.66 & 6.48 & 10.29 & 0.75 \\
\hline & 12 & -4.61 & 4.81 & 6.81 & 10.83 & 0.65 \\
\hline
\end{tabular}


Table 4.6 - Probabilities of seedling establishment used in all LANDIS-II scenarios. These probabilities were determined through a LANDIS-II calculator based on the LINKAGES model (Pastor and Post 1985) with inputs from Tables 4.4 and 4.5.

\begin{tabular}{l|rr}
\hline \multicolumn{1}{c}{ Species } & NHAM & SHAM \\
\hline Red maple & 0.454 & 0.668 \\
Sugar maple & 0.496 & 0.652 \\
Yellow birch & 0.436 & 0.251 \\
White ash & 0.235 & 0.575 \\
American beech & 0.289 & 0.593 \\
Yellow-poplar & 0.001 & 0.095 \\
Red spruce & 0.495 & 0.295 \\
Eastern white pine & 0.774 & 0.782 \\
Black cherry & 0.045 & 0.262 \\
Northern red oak & 0.272 & 0.552 \\
White oak & 0.167 & 0.492 \\
Basswood & 0.391 & 0.696 \\
Hemlock & 0.698 & 0.896 \\
\hline
\end{tabular}

Table 4.7 - Relevant biomass parameters used in all LANDIS-II scenarios.

\begin{tabular}{l|cccc}
\hline \multicolumn{1}{c|}{ Species } & $\begin{array}{c}\text { Mortality } \\
\text { curve } \\
\text { parameter }\end{array}$ & $\begin{array}{c}\text { Age of } \\
\text { age- } \\
\text { related } \\
\text { mortality }\end{array}$ & $\begin{array}{c}\text { Maximum } \\
\text { biomass } \\
\left(\mathbf{g} / \mathbf{m}^{2}\right)\end{array}$ & $\begin{array}{c}\text { Maximum } \\
\text { annual net } \\
\text { primary } \\
\text { productivity } \\
\left(\mathbf{g} / \mathbf{m}^{2} / \mathbf{y r}\right)\end{array}$ \\
\hline Red maple & 15 & $80^{1}$ & 25390 & 1086 \\
Sugar maple & 15 & $150^{2}$ & 25390 & 1086 \\
Yellow birch & 15 & $150^{2}$ & 25390 & 1086 \\
White ash & 20 & $100^{3}$ & 25390 & 1086 \\
Beech & 20 & $200^{3}$ & 25390 & 1086 \\
Yellow-poplar & 20 & $167^{3}$ & 25390 & 1086 \\
Red spruce & 20 & $267^{3}$ & 18530 & 968 \\
Black cherry & 15 & $100^{2}$ & 25390 & 1086 \\
Northern red oak & 20 & $167^{3}$ & 24420 & 1108 \\
White oak & 20 & $233^{3}$ & 24420 & 1108 \\
Basswood & 15 & $100^{4}$ & 25390 & 1086 \\
Hemlock & 20 & $300^{2}$ & 18530 & 968 \\
\hline
\end{tabular}

1 - Fowells $1965 ;{ }^{2}$ - Burns and Honkala $1990 ;{ }^{3}$ - default of $67 \%$ of longevity; ${ }^{4}-$ Nesom 2006 
Table 4.8 - Forest types by percent of total study area (MP4.1 stands only) by scenario and model year.

\begin{tabular}{|c|c|c|c|c|c|c|c|c|c|c|c|}
\hline \multirow{2}{*}{$\begin{array}{c}\text { Scenario } \\
\text { and forest type }\end{array}$} & \multicolumn{11}{|c|}{ Model Year } \\
\hline & 0 & 10 & 20 & 30 & 40 & 50 & 60 & 70 & 80 & 90 & 100 \\
\hline \multicolumn{12}{|l|}{ S1 } \\
\hline northern hardwoods & 20.2 & 20.9 & 21.3 & 21.4 & 21.5 & 21.6 & 21.7 & 21.8 & 21.8 & 21.9 & 22.0 \\
\hline red spruce-northern hardwoods & 36.1 & 36.5 & 36.7 & 36.9 & 37.1 & 37.2 & 37.4 & 37.6 & 37.7 & 37.8 & 37.9 \\
\hline mixed cove & 36.2 & 36.7 & 36.9 & 37.0 & 37.1 & 37.2 & 37.3 & 37.3 & 37.3 & 37.3 & 37.3 \\
\hline mixed oak & 0.4 & 1.2 & 1.6 & 1.9 & 2.0 & 2.1 & 2.2 & 2.3 & 2.4 & 2.3 & 2.3 \\
\hline \multicolumn{12}{|l|}{ S2 } \\
\hline northern hardwoods & 20.2 & 20.9 & 21.3 & 21.5 & 21.5 & 21.6 & 21.7 & 21.8 & 21.8 & 21.9 & 22.0 \\
\hline red spruce-northern hardwoods & 36.1 & 36.5 & 36.7 & 36.9 & 37.1 & 37.2 & 37.4 & 37.6 & 37.7 & 37.8 & 37.9 \\
\hline mixed cove & 36.2 & 36.8 & 36.9 & 37.0 & 37.1 & 37.2 & 37.3 & 37.3 & 37.3 & 37.3 & 37.3 \\
\hline mixed oak & 0.4 & 1.1 & 1.6 & 1.9 & 2.0 & 2.0 & 2.2 & 2.3 & 2.3 & 2.3 & 2.3 \\
\hline \multicolumn{12}{|l|}{ S3 } \\
\hline northern hardwoods & 20.2 & 20.8 & 20.9 & 21.0 & 20.9 & 21.1 & 21.2 & 21.3 & 21.2 & 21.2 & 21.1 \\
\hline red spruce-northern hardwoods & 36.1 & 36.6 & 37.0 & 37.4 & 37.7 & 37.9 & 38.1 & 38.4 & 38.6 & 38.7 & 38.9 \\
\hline mixed cove & 36.2 & 36.7 & 36.9 & 37.0 & 37.1 & 37.0 & 36.9 & 36.9 & 36.9 & 37.0 & 37.1 \\
\hline mixed oak & 0.4 & 1.2 & 1.6 & 1.9 & 2.0 & 2.1 & 2.3 & 2.4 & 2.4 & 2.4 & 2.4 \\
\hline \multicolumn{12}{|l|}{ S4 } \\
\hline northern hardwoods & 20.2 & 20.9 & 21.0 & 21.4 & 21.5 & 21.6 & 21.7 & 21.8 & 21.8 & 21.9 & 22.0 \\
\hline red spruce-northern hardwoods & 36.1 & 36.5 & 36.6 & 36.9 & 37.1 & 37.2 & 37.4 & 37.6 & 37.7 & 37.8 & 37.9 \\
\hline mixed cove & 36.2 & 36.8 & 36.9 & 37.0 & 37.1 & 37.2 & 37.3 & 37.3 & 37.3 & 37.3 & 37.3 \\
\hline mixed oak & 0.4 & 1.1 & 1.2 & 1.9 & 2.0 & 2.0 & 2.2 & 2.3 & 2.3 & 2.3 & 2.3 \\
\hline
\end{tabular}


Figure 4.1 - Location of study area and model area. Stands assigned to management prescription (MP) 4.1 in the Monongahela National Forest Forest Plan were buffered by $5 \mathrm{~km}$ to create the model area; however results are only reported for the MP4.1 (study) area.

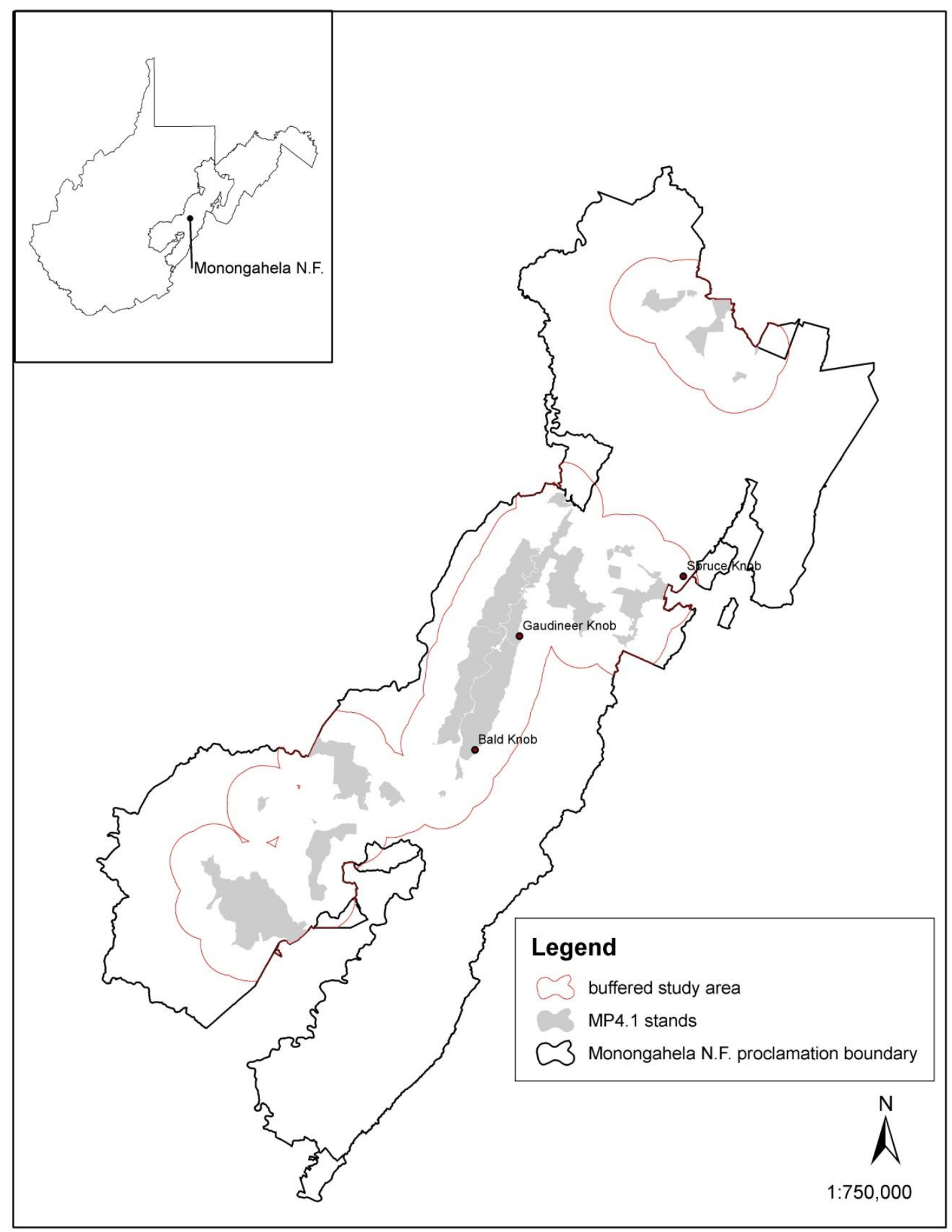


Figure 4.2 - Mean percentage $( \pm \mathrm{SE})$ of red spruce and red spruce-northern hardwood forest types for the 1-19 year age class as a result of implementing the four LANDIS-II scenarios; National Forest land in MP4.1 only. The four model scenarios are: 1) harvest in both management areas (S1), 2) harvest in management area one only (low-to moderate probability of VNFS occupation, S2), 3) harvest in both management areas with the exclusion of stands with $30 \%$ or greater red spruce of 80 years or older (S3), and 4) succession only (S4).

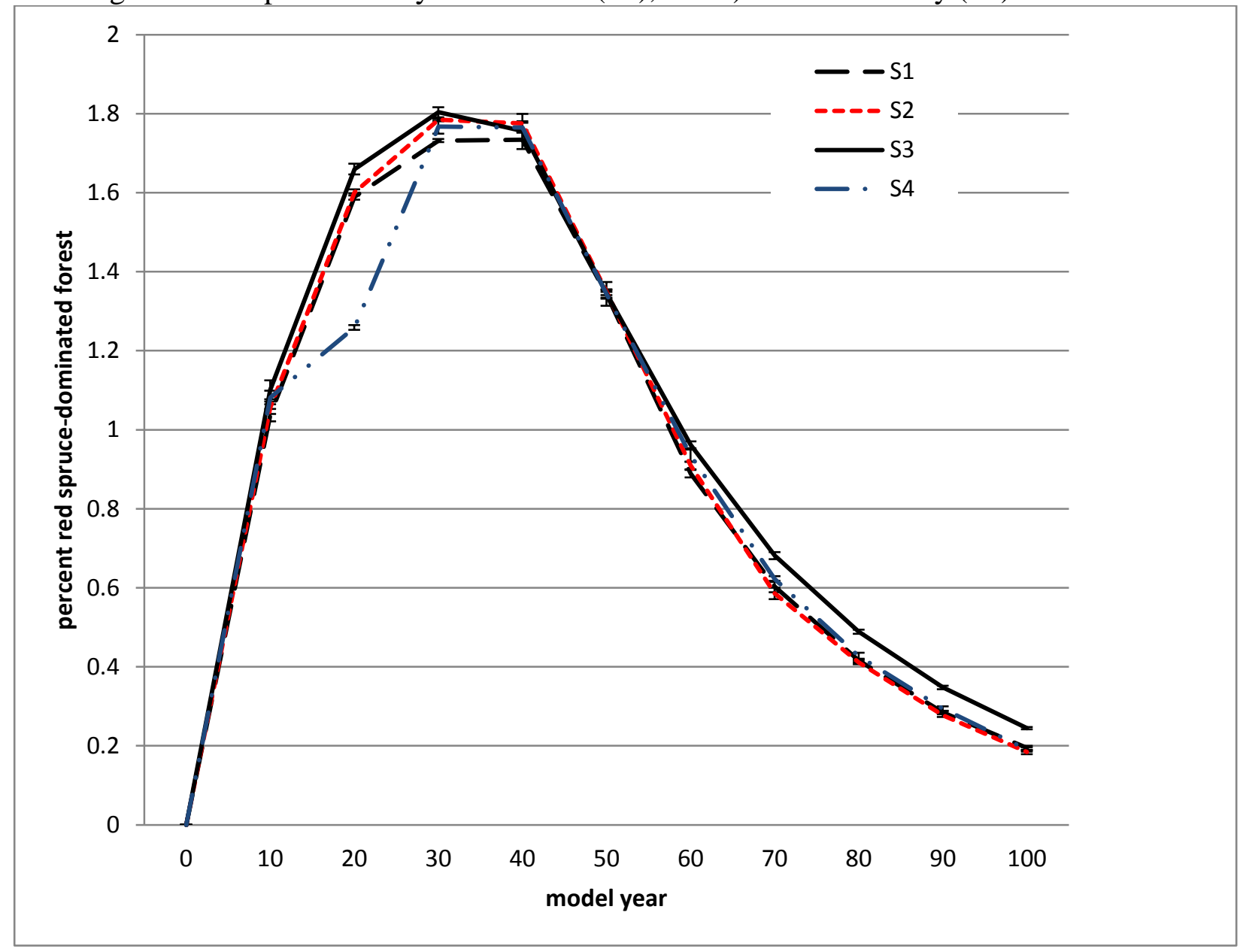


Figure 4.3 - Mean percentage $( \pm \mathrm{SE})$ of red spruce and red spruce-northern hardwood forest types for the 20-39 year age class as a result of implementing the four LANDIS-II scenarios; National Forest land in MP4.1 only. The four model scenarios are: 1) harvest in both management areas (S1), 2) harvest in management area one only (low-to moderate probability of VNFS occupation, S2), 3) harvest in both management areas with the exclusion of stands with $30 \%$ or greater red spruce of 80 years or older (S3), and 4) succession only (S4).

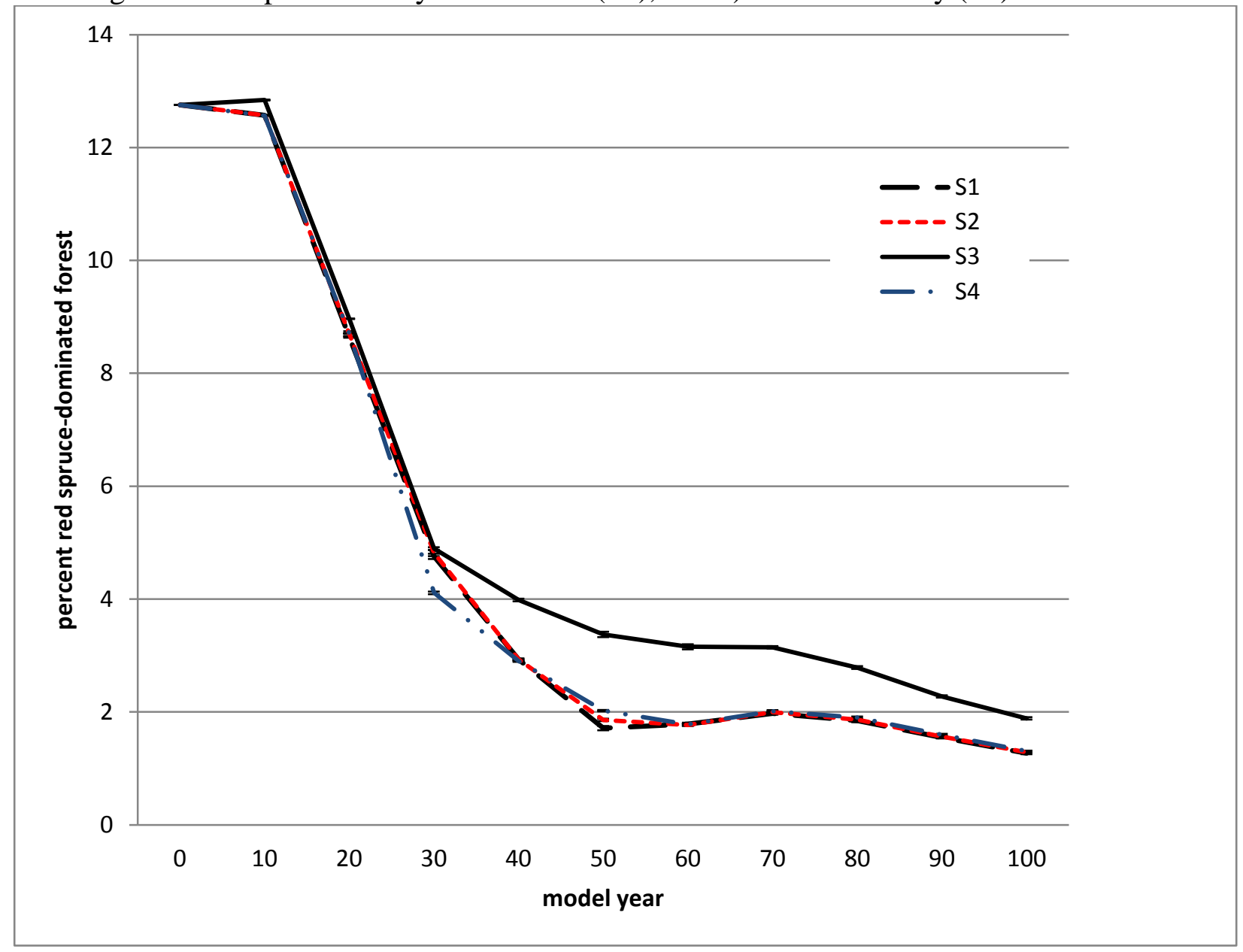


Figure 4.4 - Mean percentage $( \pm \mathrm{SE})$ of red spruce and red spruce-northern hardwood forest types for the 40-79 year age class as a result of implementing the four LANDIS-II scenarios; National Forest land in MP4.1 only. The four model scenarios are: 1) harvest in both management areas (S1), 2) harvest in management area one only (low-to moderate probability of VNFS occupation, S2), 3) harvest in both management areas with the exclusion of stands with $30 \%$ or greater red spruce of 80 years or older (S3), and 4) succession only (S4).

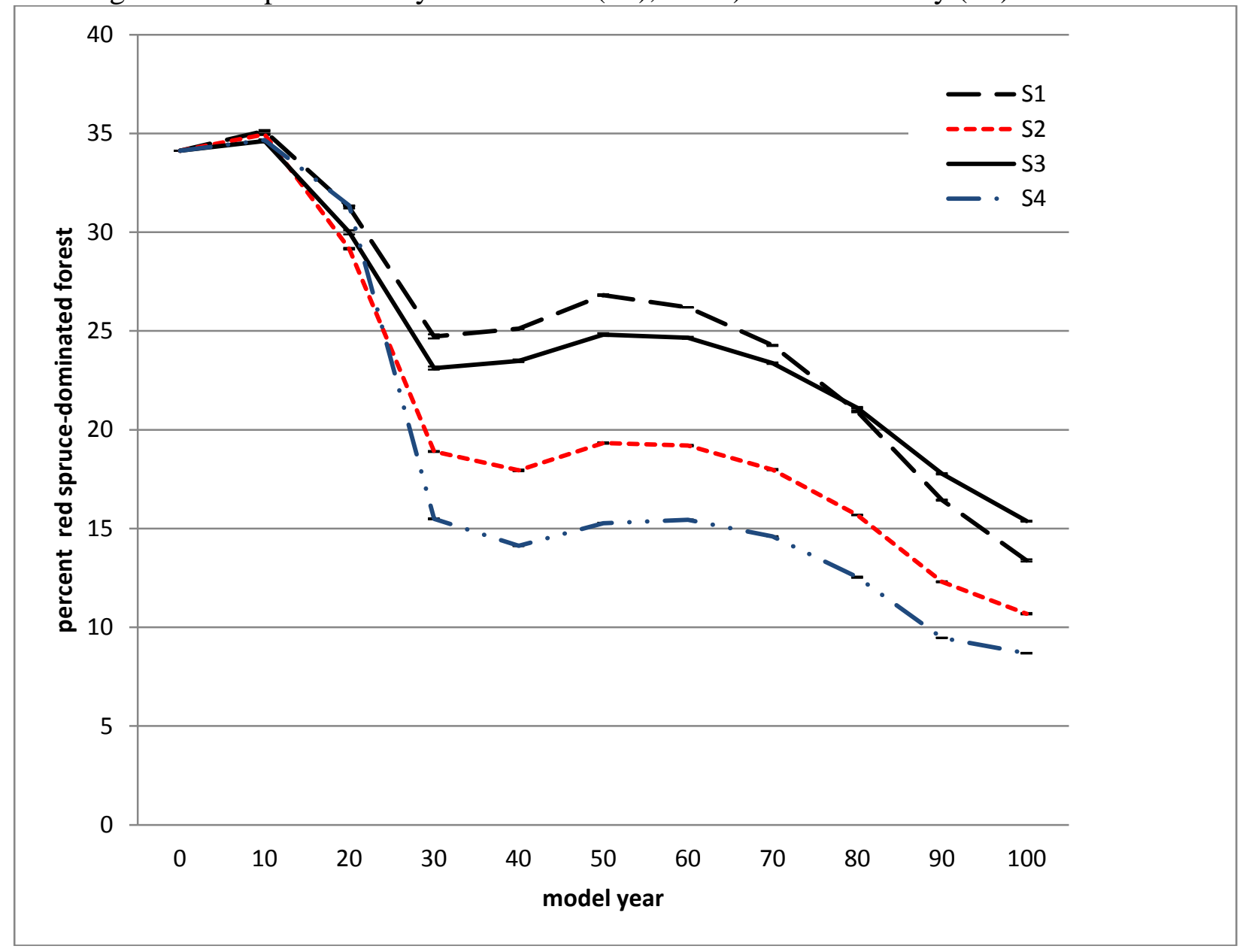


Figure 4.5 - Mean percentage $( \pm \mathrm{SE})$ of red spruce and red spruce-northern hardwood forest types for the 80-119 year age class as a result of implementing the four LANDIS-II scenarios; National Forest land in MP4.1 only. The four model scenarios are: 1) harvest in both management areas (S1), 2) harvest in management area one only (low-to moderate probability of VNFS occupation, S2), 3) harvest in both management areas with the exclusion of stands with $30 \%$ or greater red spruce of 80 years or older (S3), and 4) succession only (S4).

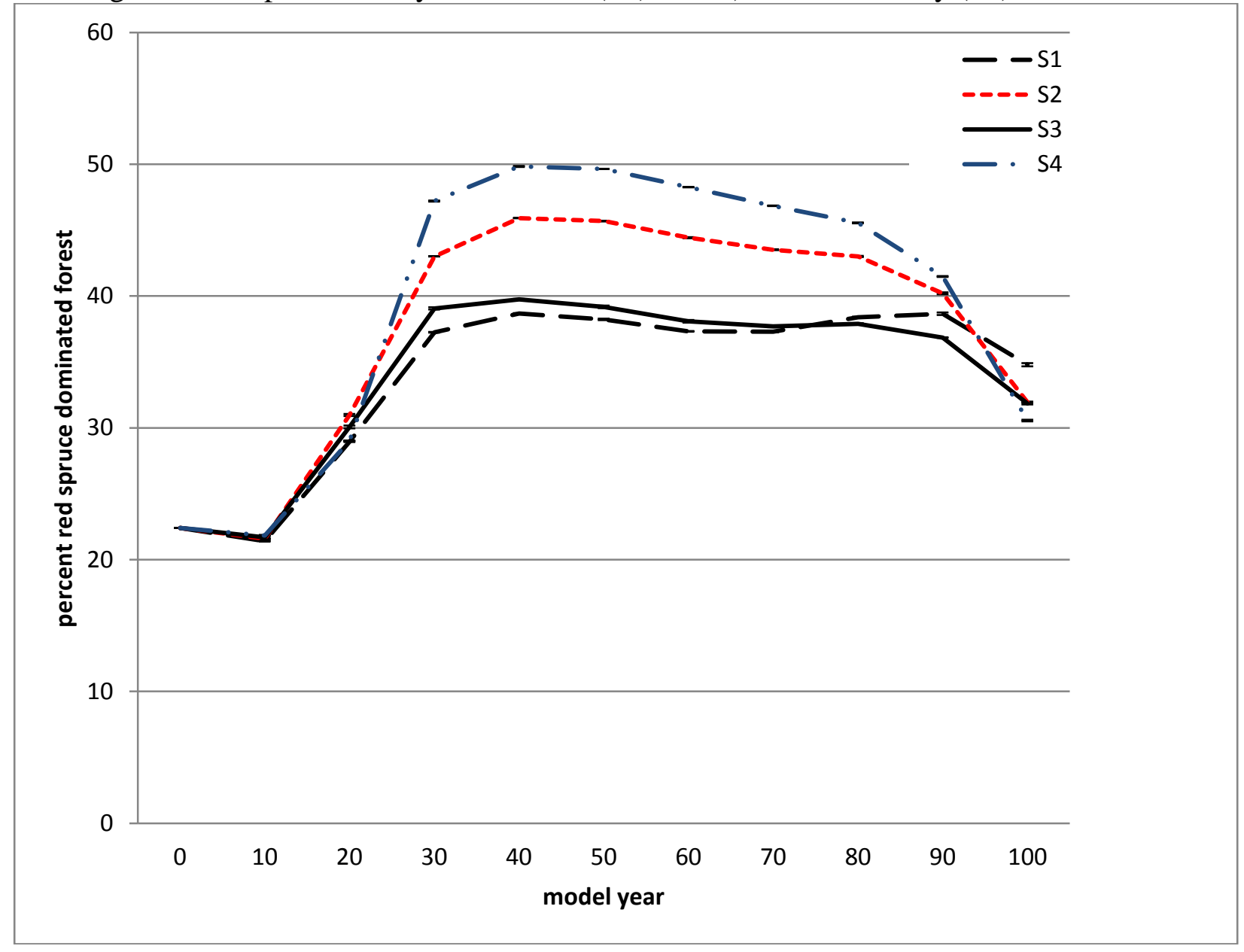


Figure 4.6 - Mean percentage $( \pm \mathrm{SE})$ of red spruce and red spruce-northern hardwood forest types for the 120+ year age class as a result of implementing the four LANDIS-II scenarios; National Forest land in MP4.1 only. The four model scenarios are: 1) harvest in both management areas (S1), 2) harvest in management area one only (low-to moderate probability of VNFS occupation, S2), 3) harvest in both management areas with the exclusion of stands with $30 \%$ or greater red spruce of 80 years or older (S3), and 4) succession only (S4).

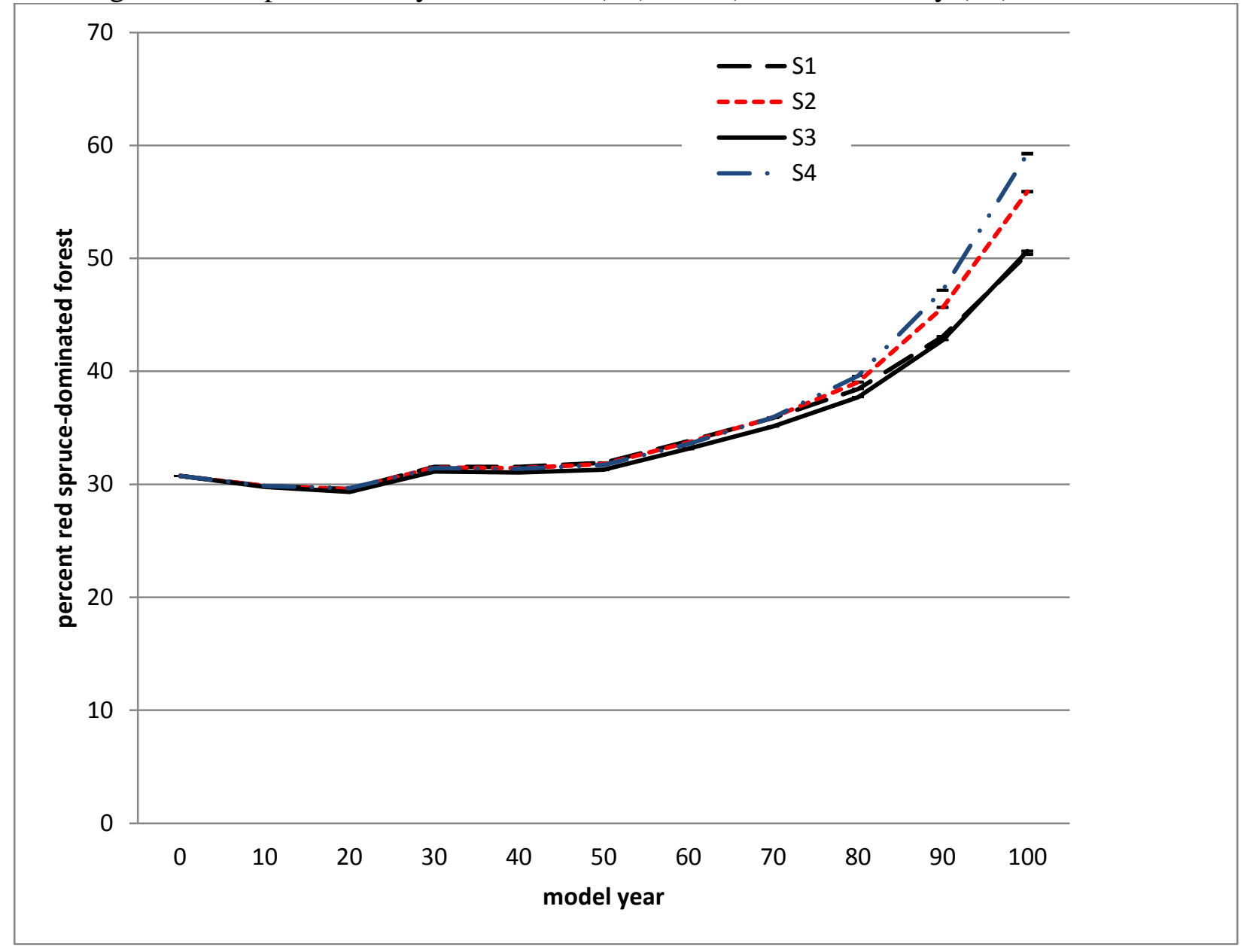


Figure 4.7 - Age classes over time for red spruce and red spruce-northern hardwood forest types combined as a result of implementing S1 in LANDIS-II. Scale for all maps is 1:24,000.
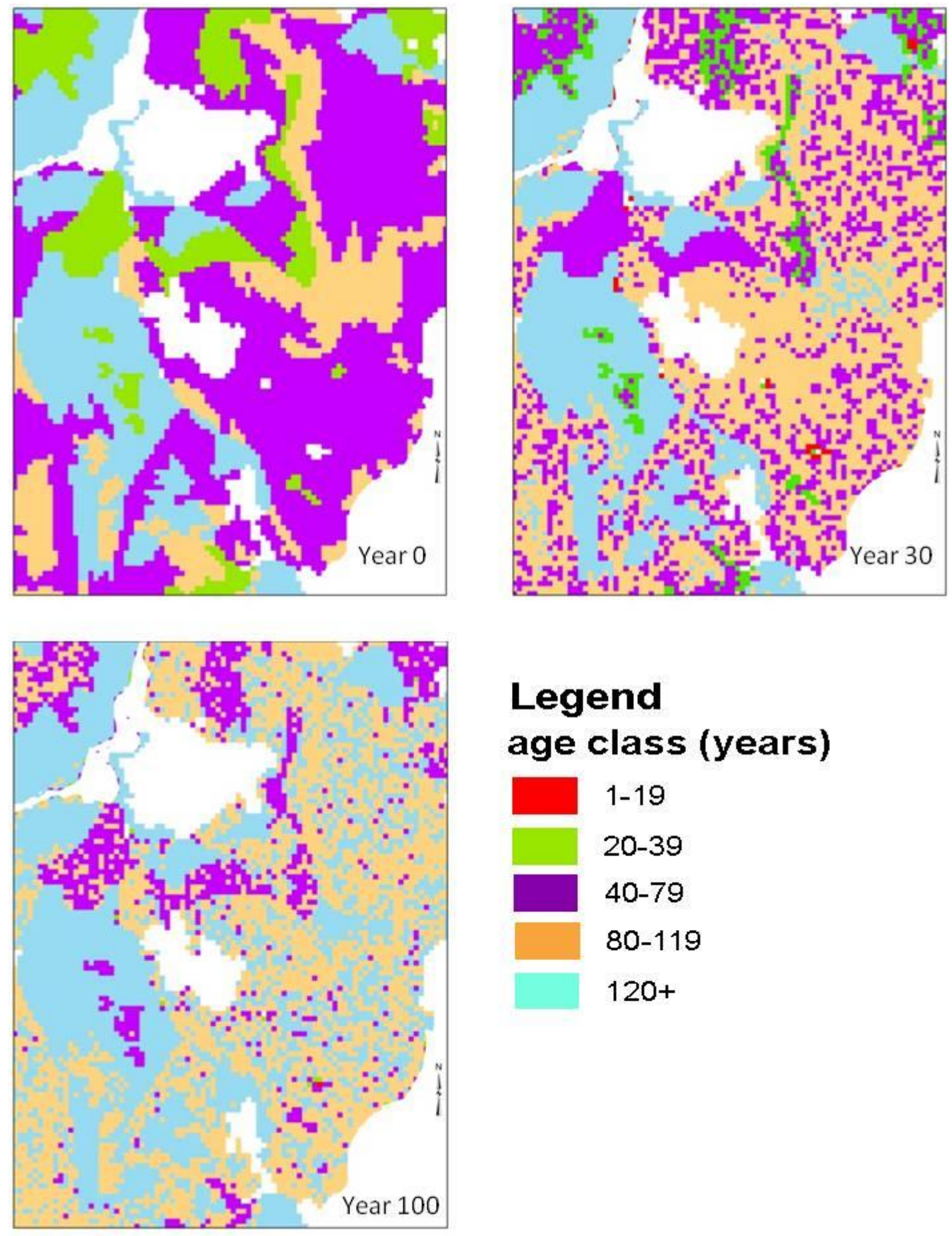

\section{Legend age class (years)}

\begin{tabular}{|l|l|}
\hline $1-19$ \\
\hline $20-39$ \\
$40-79$ \\
$80-119$ \\
$120+$ \\
\hline
\end{tabular}


Figure 4.8 - Age classes over time for red spruce and red spruce-northern hardwood forest types combined as a result of implementing S2 in LANDIS-II. Scale for all maps is 1:24,000.
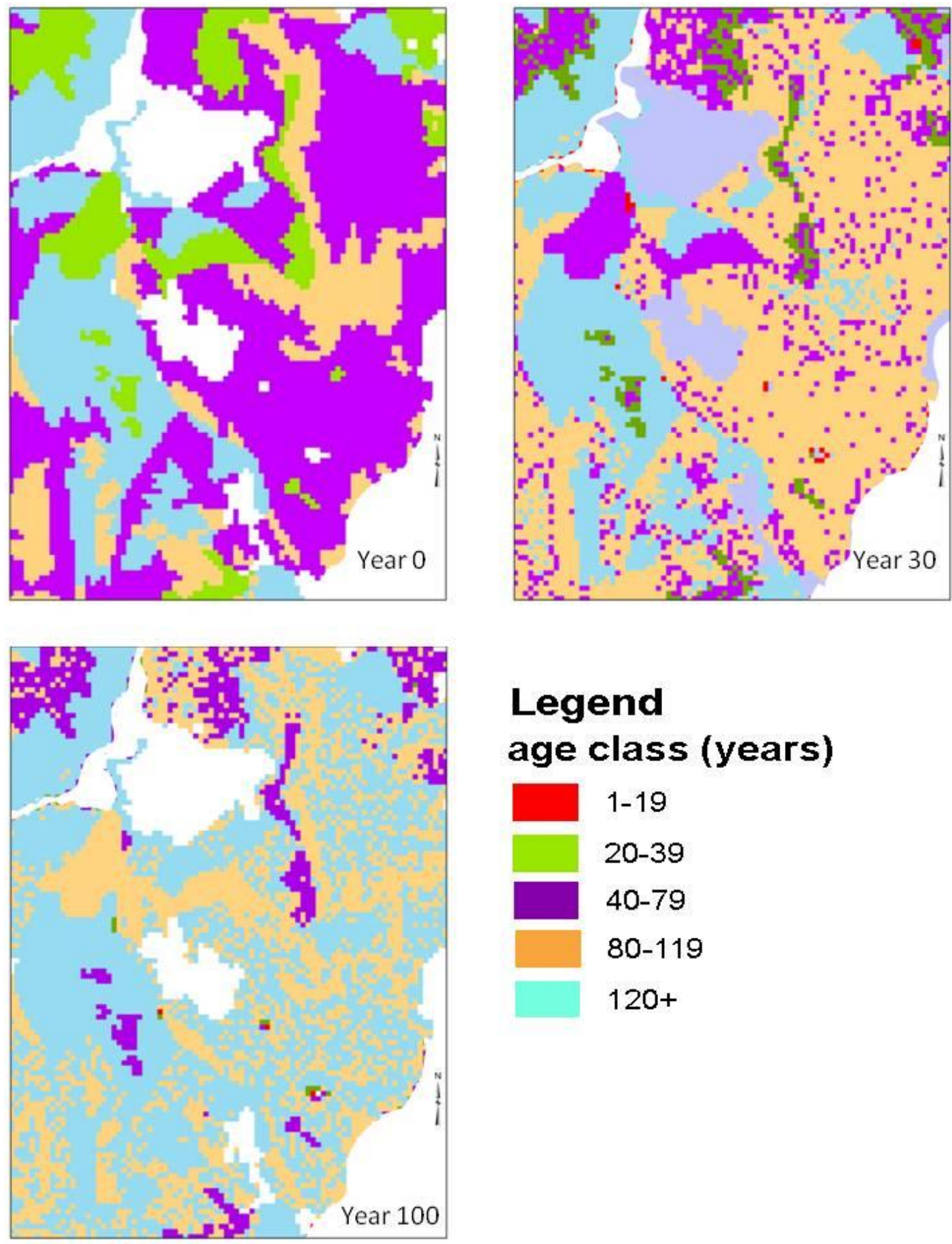

\section{Legend age class (years)}

$1-19$

20-39

40-79

80-119

$120+$ 
Figure 4.9 - Age classes over time for red spruce and red spruce-northern hardwood forest types combined as a result of implementing S3 in LANDIS-II. Scale for all maps is 1:24,000.
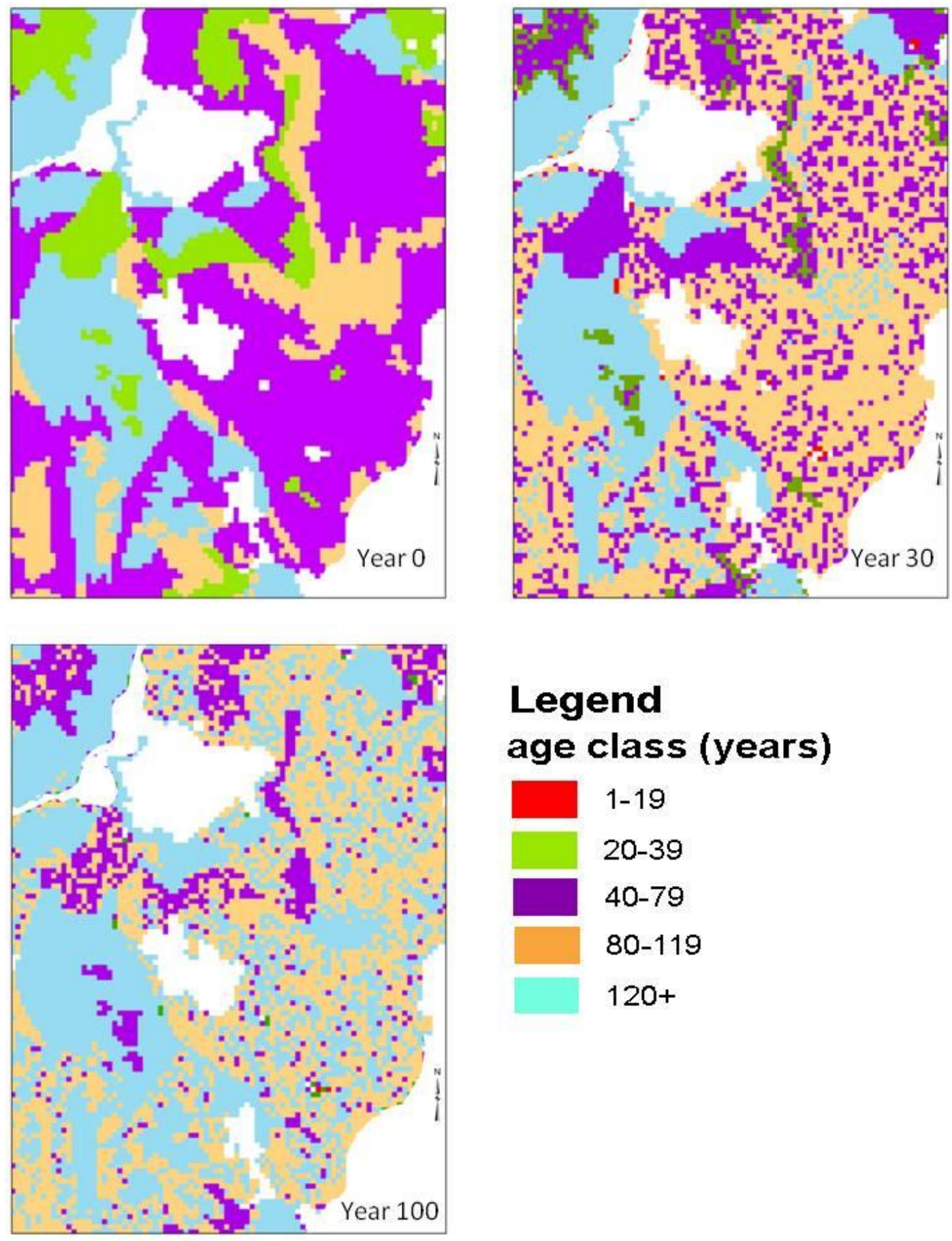

\section{Legend age class (years)}

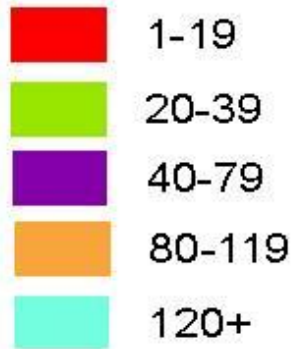


Figure 4.10 - Age classes over time for red spruce and red spruce-northern hardwood forest types combined as a result of implementing S4 in LANDIS-II. Scale for all maps is 1:24,000.
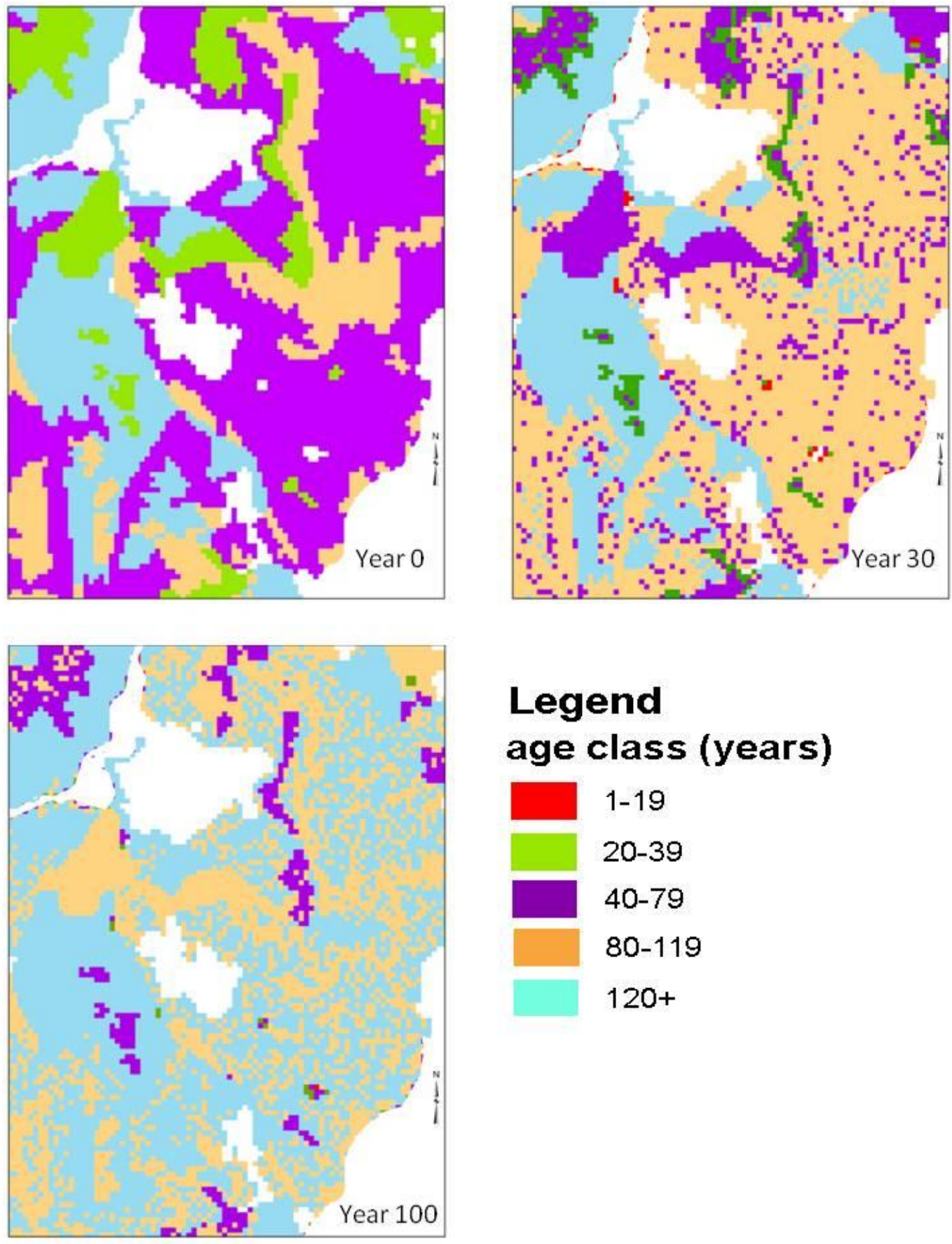

\section{Legend} age class (years)

\begin{tabular}{|l|l|}
\hline $1-19$ \\
\hline $20-39$ \\
$40-79$ \\
$80-119$ \\
$120+$ \\
\hline
\end{tabular}


Figure 4.11 - Area harvested $( \pm \mathrm{SE})$ by model decade; National Forest land in MP4.1 only. Average values are for three model runs for each of the three scenarios that include harvest: 1) harvest in both management areas (S1), 2) harvest in management area one only (low-to moderate probability of VNFS occupation, S2), 3) harvest in both management areas with the exclusion of with $30 \%$ or greater red spruce of 80 years or older (S3).

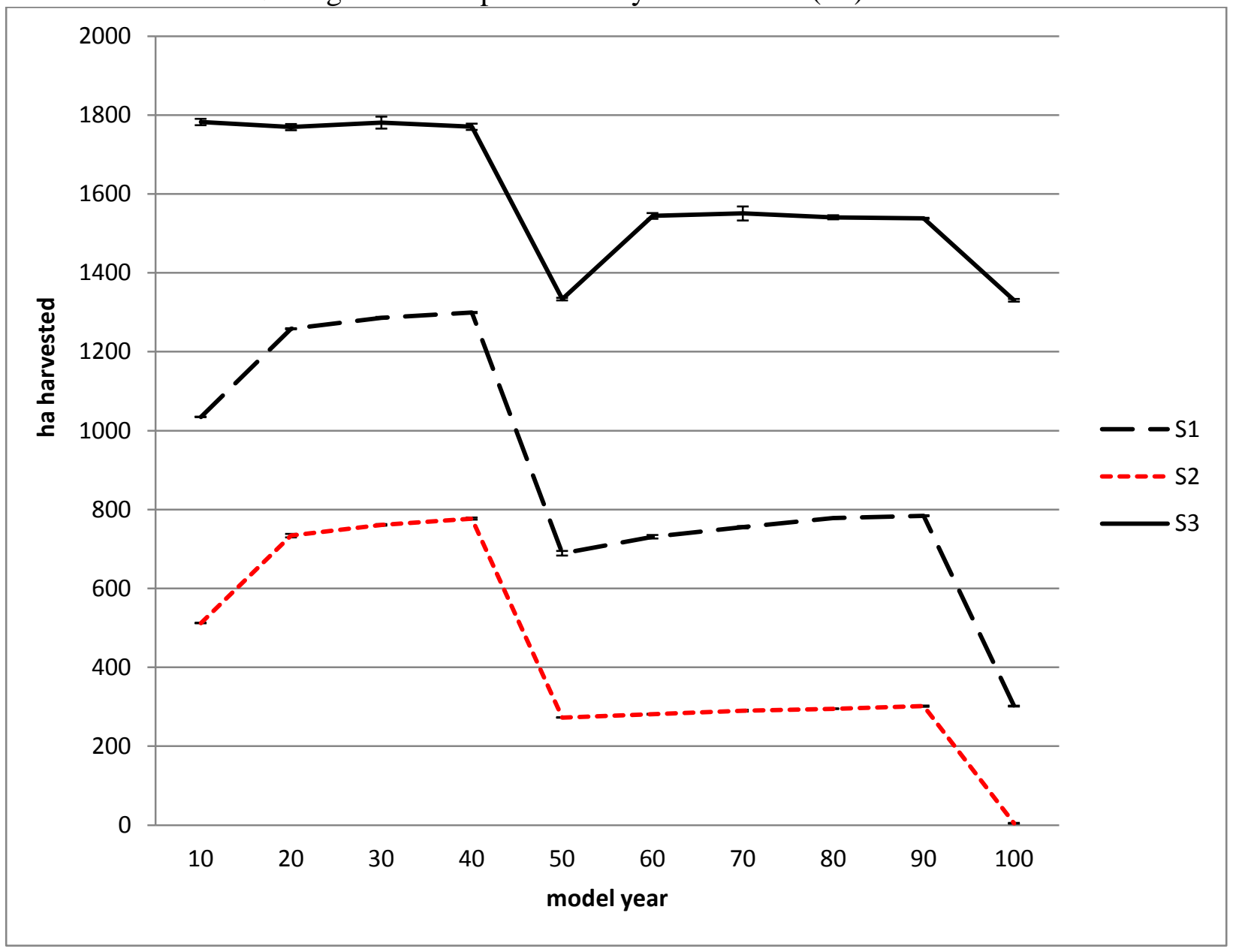


Figure 4.12 - Species removals by decade as a percent of total cohorts removed for S1 - harvests in both management areas.

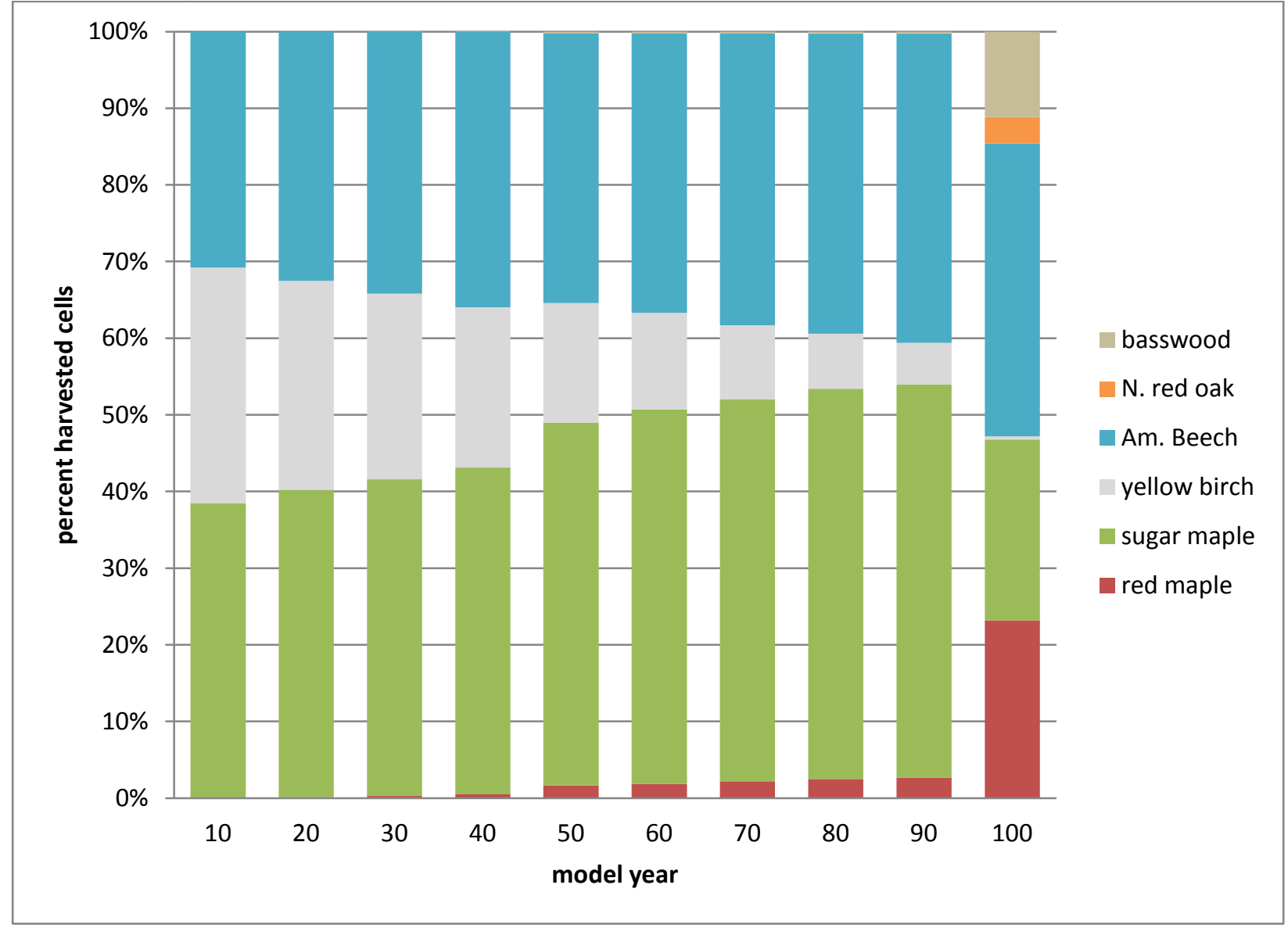


Figure 4.13 - Species removals by decade as a percent of total cohorts removed for S2 - harvests in management area 1 only.

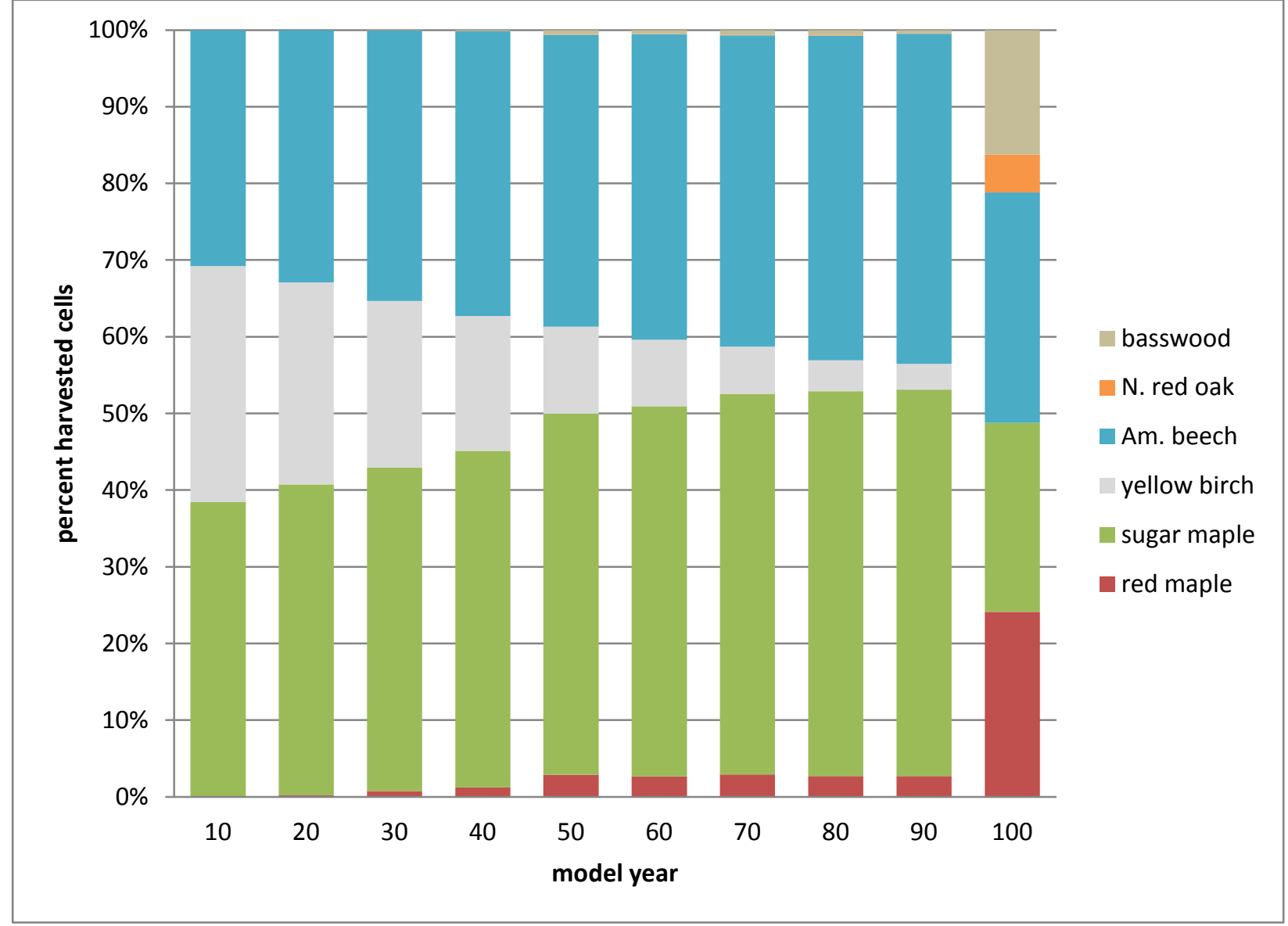


Figure 4.14 - Species removals by decade as a percent of total cohorts removed for S3 - harvests in both management areas, excluding with $30 \%$ or more red spruce of 80 years or older.

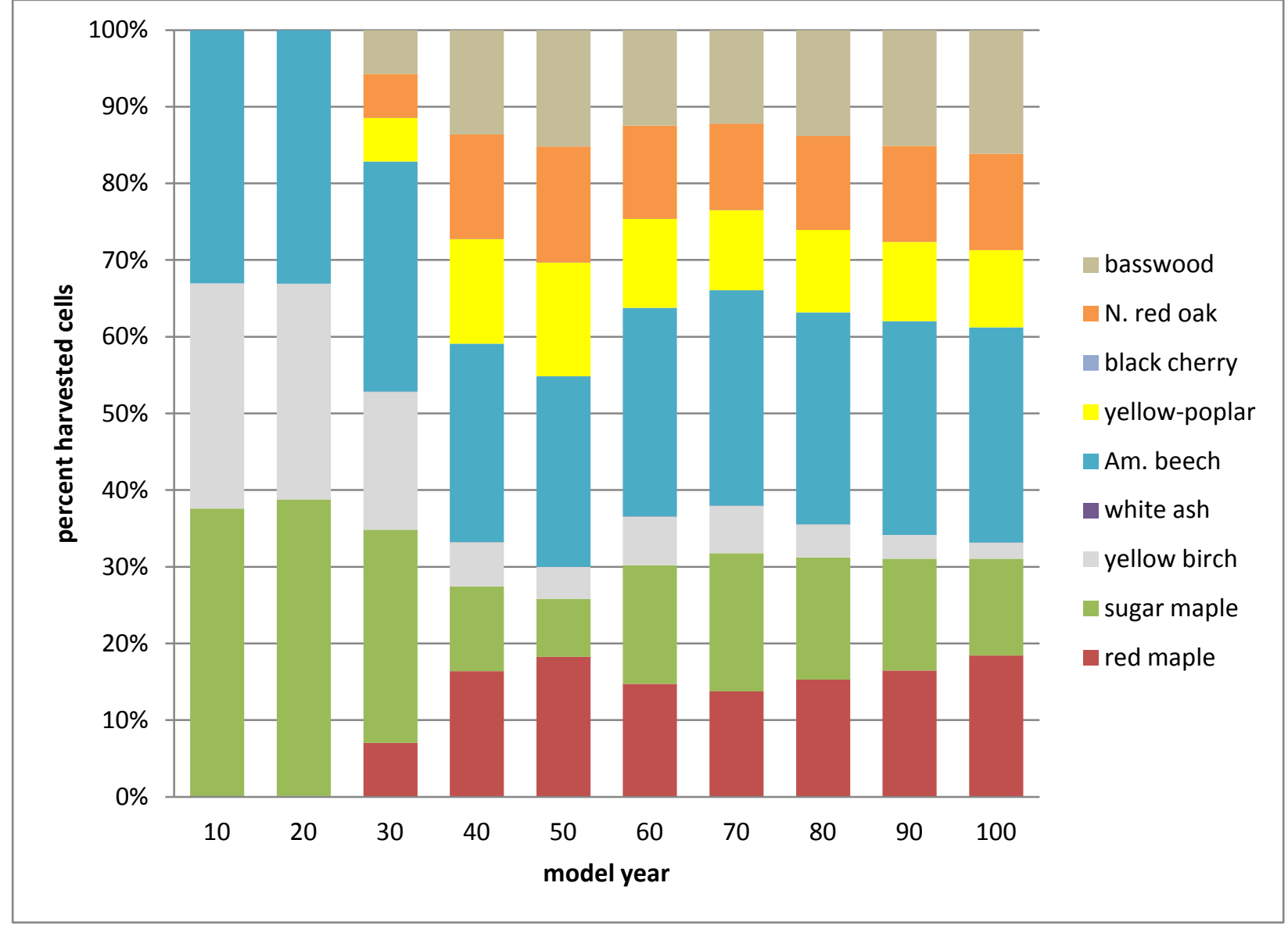


Figure 4.15 - Ages of harvested stands by decade as percent of total stands harvested for S1 harvests in both management areas.

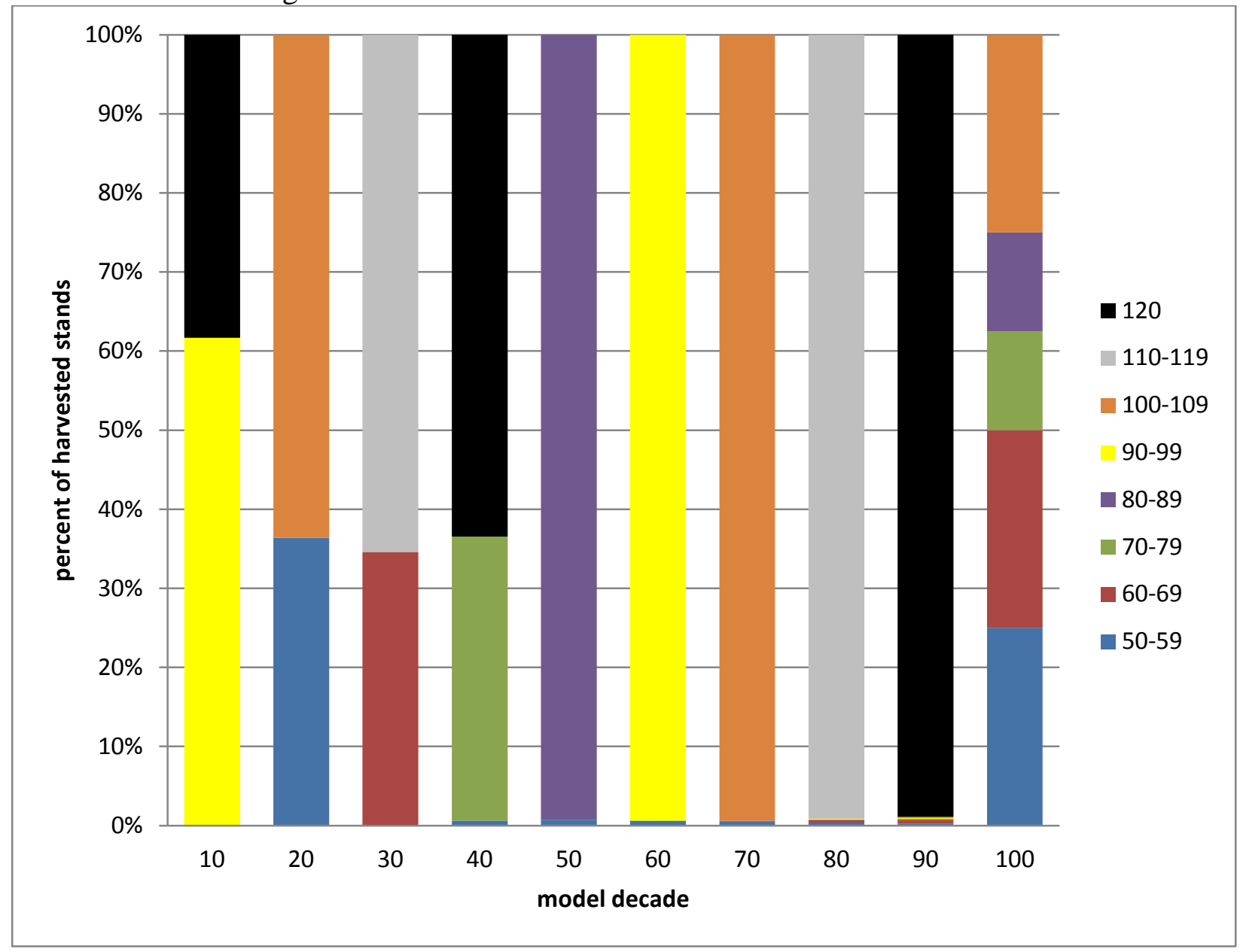


Figure 4.16 - Ages of harvested stands by decade as percent of total stands harvested for S2 harvests in management area 1 only.

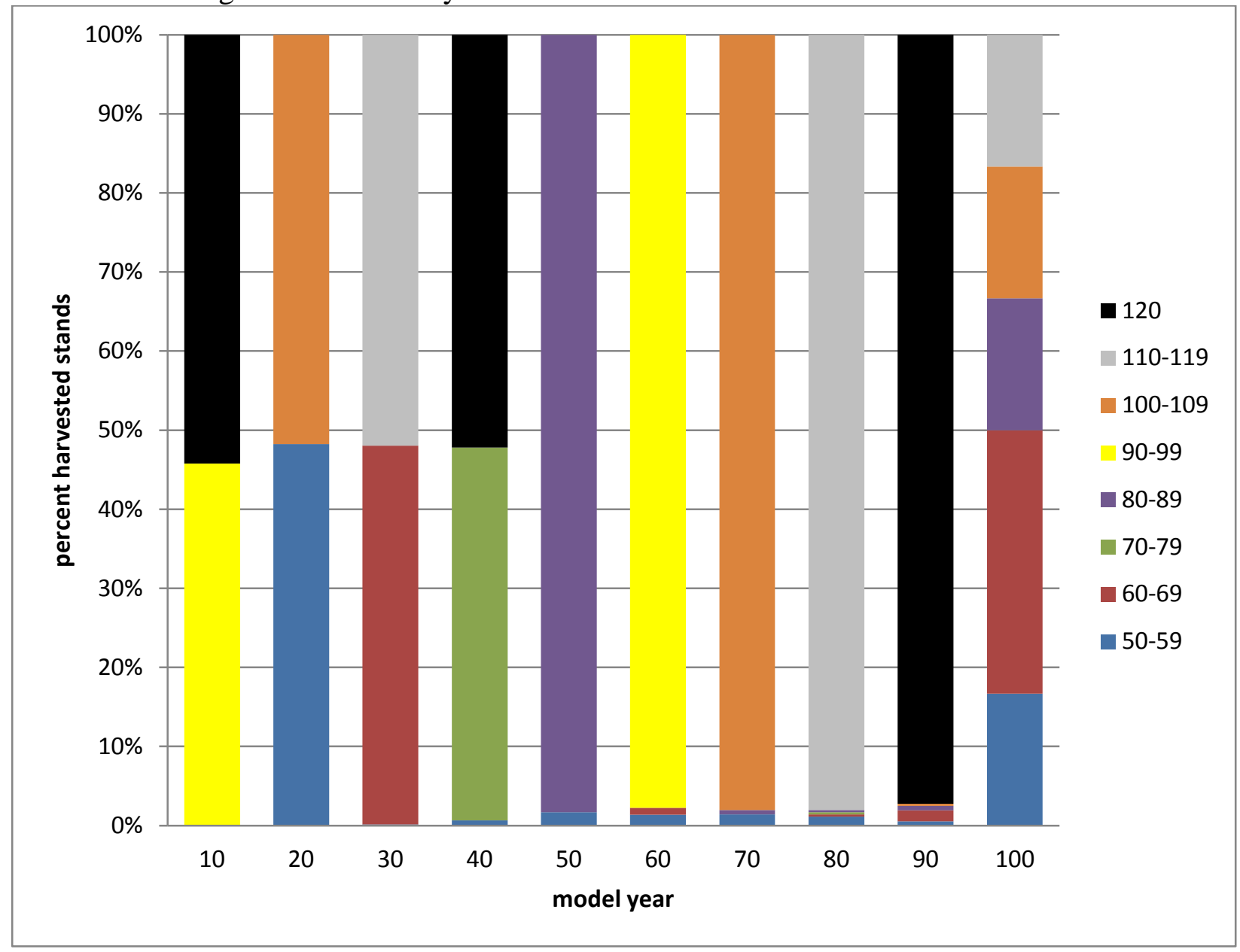


Figure 4.17 - Ages of harvested stands by decade as percent of total stands harvested for S3 harvests in both management areas, excluding stands with $30 \%$ or more red spruce of 80 years or older.

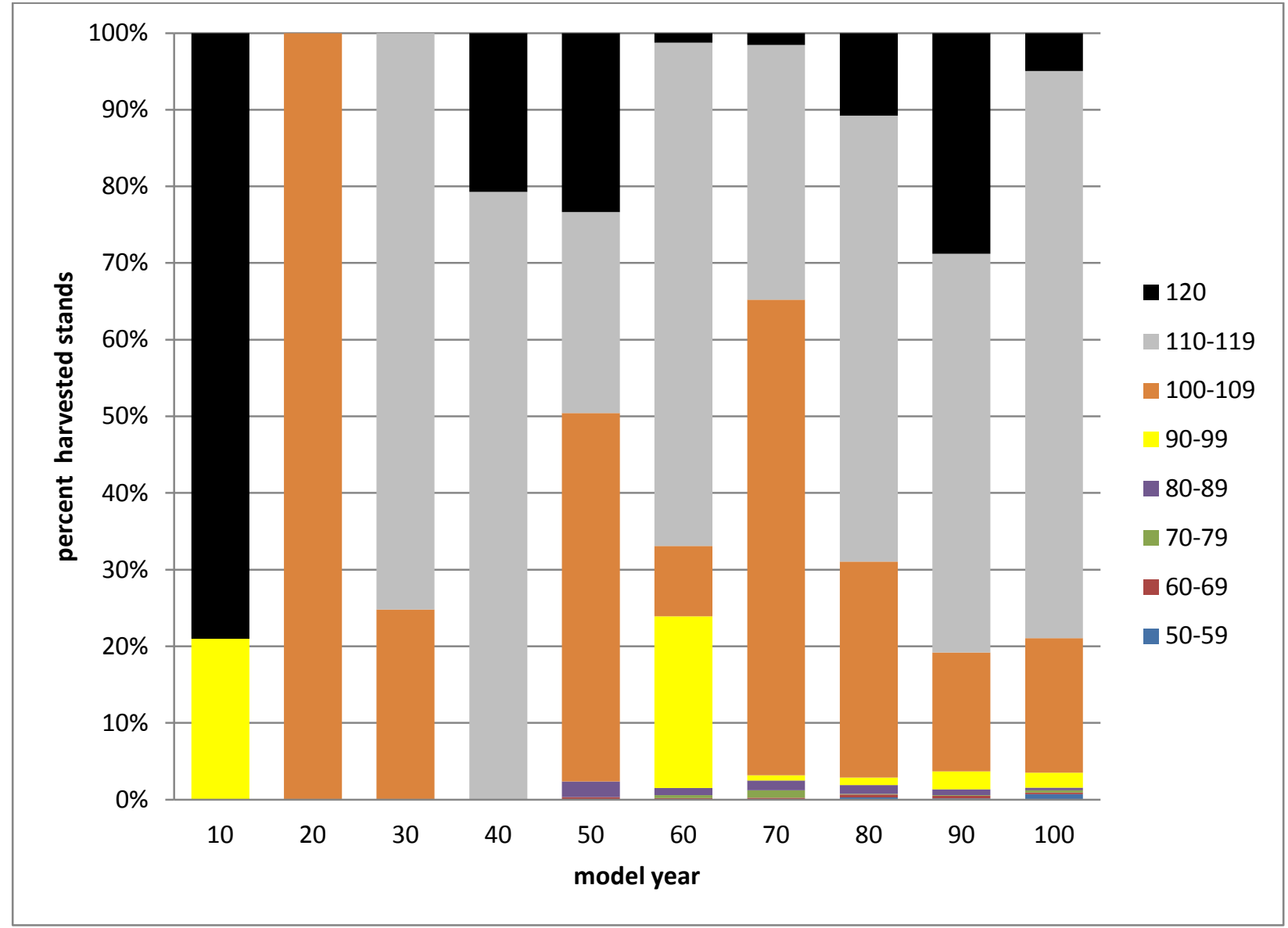


Figure 4.18 - Percentage of the study area in variety classes by LANDIS-II scenario.

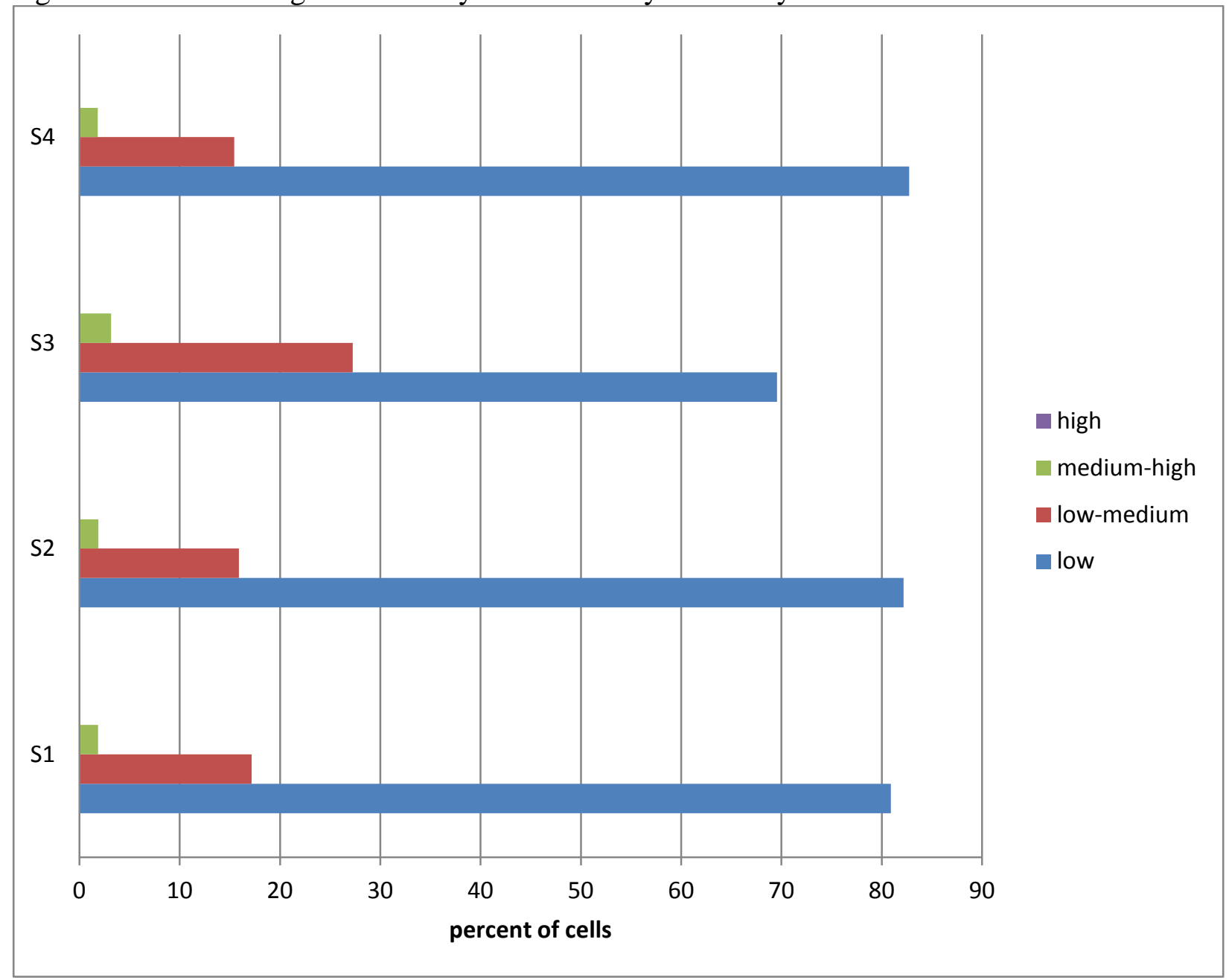

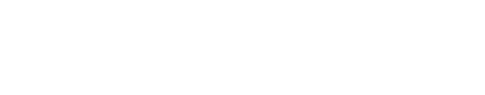

